UNIVERSIDADE DE SÃO PAULO

INSTITUTO DE ESTUDOS BRASILEIROS

PROGRAMA DE PÓS-GRADUAÇÃO

CULTURAS E IDENTIDADES BRASILEIRAS

CAMILA RUSSO DE ALMEIDA SPAGNOLI

Monteiro Lobato, o leitor 


\author{
UNIVERSIDADE DE SÃO PAULO \\ INSTITUTO DE ESTUDOS BRASILEIROS \\ PROGRAMA DE PÓS-GRADUAÇÃO \\ CULTURAS E IDENTIDADES BRASILEIRAS
}

\title{
Monteiro lobato, o leitor
}

\section{CAMILA RUSSO DE ALMEIDA SPAGNOLI}

Dissertação apresentada ao Programa de Pós-Graduação Culturas e Identidades Brasileiras do Instituto de Estudos Brasileiros da Universidade de São Paulo, para a obtenção do título de Mestre em Filosofia.

Área de concentração: Estudos Brasileiros

Orientador: Profa. Dra. Therezinha Apparecida Porto Ancona Lopez

Versão corrigida: O exemplar original encontra-se disponível na Biblioteca do Instituto de Estudos Brasileiros (IEB/USP)

São Paulo 
DADOS DE CATALOGAÇÃO NA PUBLICAÇÃO (CIP)

Serviço de Biblioteca e Documentação do

Instituto de Estudos Brasileiros da Universidade de São Paulo

(C) reprodução total

Spagnoli, Camila Russo de Almeida

Monteiro Lobato, o leitor / Camila Russo de Almeida Spagnoli -São Paulo, 2014.

Orientadora : Profa.Dra. Therezinha Apparecida Porto Ancona Lopez.

Dissertação (Mestrado) - Universidade de São Paulo. Instituto de Estudos Brasileiros. Programa de Pós-Graduação. Área de concentração: Estudos Brasileiros. Linha de pesquisa: Brasil: a realidade da criação, a criação da realidade.

Versão do título para o inglês: Monteiro Lobato, the reader.

Descritores: 1. Lobato, Monteiro, 1882-1948 2. Literatura brasileira 3. Literatura infanto-juvenil 4. Epistolografia 5. Crítica genética

6. Leitura I. Universidade de São Paulo. Instituto de Estudos

Brasileiros. Programa de Pós-Graduação II. Título. 
Para Osmar Franchetti Spagnoli,

o melhor dos companheiros de jornada, o amor de minha vida. 


\section{Agradecimentos}

À minha orientadora, Telê Ancona Lopez, sempre dedicada e exigente. Foram três anos de pesquisa em que muito aprendi com suas explicações, principalmente quanto a sair do óbvio e aproveitar o material que tinha em mãos. Sou muito grata por toda a paciência e cuidado com o qual a professora corrigia cada versão que eu enviava dos textos. Tenho que confessar: ainda no Ensino Médio, li Macunaíma em uma edição coordenada pela Telê e, quando a conheci, na Universidade de São Paulo, só conseguia pensar na honra de conversar com ela. Fiquei mais honrada ainda quando soube que ela seria minha orientadora de mestrado!

À atenção e sugestões dos professores Marcos Antonio de Moraes e Marisa Lajolo, no Exame de Qualificação deste trabalho. Além disso, sempre serei grata à Profa. Marisa por ter me ajudado a dar os primeiros passos enquanto pesquisadora, quando na graduação tive a oportunidade de trabalhar com ela em minha Iniciação Científica. Foram anos que me recordo com grande carinho! Quanto ao Prof. Marcos, tive o grande prazer de frequentar suas aulas das quais eu saia sempre com ideias fervilhando em minha cabeça e com uma vontade imensa de aprender cada vez mais sobre cartas com ele!

Aos membros da banca, Profa. Dra. Marisa Philbert Lajolo, Profa. Dra. Raquel Afonso da Silva, Prof. Dr. Marcos Antonio de Moraes, Profa. Dra. Cilza Carla Bignotto e Prof. Dr. João Luís Cardoso Tápias Ceccantini.

A todos os professores que de algum modo passaram por minha vida e contribuíram muito para minha formação.

Aos professores e funcionários do IEB.

Ao pesquisador do IEB Leandro Raniero Fernandes, por sua disponibilidade e cuidado com minha dissertação, além do auxílio na formatação do texto.

À equipe do Acervo Monteiro Lobato da Biblioteca Infantil, especialmente os pesquisadores Oiram Antonini e Nelson Somma Jr pelo grande empenho em ajudar e divulgar a obra de Monteiro Lobato.

Aos funcionários do Centro de Documentação Alexandre Eulálio, do IEL, onde está arquivado o Fundo Monteiro Lobato. 
À generosidade e solicitude das pesquisadoras lobatianas Juliana Cristina Garcia e Cilza Carla Bignotto por compartilharem seu trabalho e cederem informações para esta pesquisa.

À minha amiga de Iniciação Científica, mestrado e afilhada de casamento, Raquel Nunes Endalécio, pela ajuda na pesquisa e também pela amizade. E boas risadas!

Ao Osmar Franchetti Spagnoli, meu marido, amigo, companheiro de alma e de jornada, sempre paciente quando eu estava cansada, sobretudo, com uma palavra amiga quando eu queria desistir de tudo. Obrigada por acreditar em mim. Obrigada pelos conselhos, idas à Unicamp e às bibliotecas, pelas noites sem dormir, pelas ajudas no jantar e na faxina, por bagunçar meu cabelo, por estar comigo sempre e em tudo. Obrigada por fazer os meus dias melhores e a minha vida feliz. Faltou dizer que um lobatiano e tanto depois desses anos todos!

Aos meus pais e minha irmã, orgulhos de minha vida, por todos esses anos que estiveram ao meu lado, buscando sempre o melhor e a nossa união. Em especial, minha mãe Silvana Russo de Almeida, por toda sua companhia, paciência e amor, por sempre estar ao meu lado, seja na fila de matrícula do Amarelo, no Therezinha, no Aprígio, na Usp... ou até mesmo em Florianópolis! 
"Como perder tempo com bobagens? Ler é coisa penosa; temos de mastigar, ensalivar e engolir - e que grande tolice comer palha! Alimentemo-nos dos Sumos" 


\section{Resumo}

Este trabalho se propõe a traçar um panorama das possíveis leituras realizadas por Monteiro Lobato, mediante o registro de referências a elas existentes nas cartas do escritor, e a pesquisa de obras que fizeram parte de suas estantes. A primeira parte da dissertação visa ao levantamento das leituras - autores e obras - citadas nas cartas remetidas por Lobato a Godofredo Rangel entre 1903 e 1948. As cartas compõem A barca de Gleyre: quarenta anos de correspondência literária entre Monteiro Lobato e Godofredo Rangel (Companhia Editora Nacional), coletânea editada pelo primeiro em 1944. A segunda parte dedica-se a estudar as relações do escritor com os títulos que restaram no Fundo Monteiro Lobato, depositado no CEDAE/ UNICAMP, e no acervo da Biblioteca Infantil Monteiro Lobato.

Palavras-chave: Monteiro Lobato; Godofredo Rangel; Correspondência; Crítica Genética; Biblioteca de Escritores. 


\begin{abstract}
This work proposes a perspective of possibles readings made by Monteiro Lobato, through the register of references in his letters, and the research into the books that belonged to his bookcases. The first part of this dissertation aims to map readings - writers and works quoted in letters sent by Lobato to Godofredo Rangel, between 1903 and 1948. The letters compose A barca de Gleyre: quarenta anos de correspondência literária entre Monteiro Lobato e Godofredo Rangel (by the Companhia Editora Nacional), collection edited by Lobato in 1944. The second part dedicates to studying the relation between the writer and the titles that remained in the Fundo Monteiro Lobato deposited in the CEDAE/ UNICAMP, and in the colletion of the Bibiblioteca Infantil Monteiro Lobato.
\end{abstract}

Palavras-chave: Monteiro Lobato; Godofredo Rangel; Correspondence; Genetic Criticism; Writers Library. 


\section{Índice de Ilustrações}

Capa do exemplar de A Child's History of the World de Lobato, conservado no acervo da Biblioteca

Infantil Monteiro Lobato, São Paulo..

Folha de rosto do exemplar conservado no acervo do escritor (Biblioteca Infantil Monteiro Lobato, São Paulo).

Ilustração do ostracismo assinalada com cruzeta a lápis azul na leitura de Lobato (Biblioteca Infantil Monteiro Lobato, São Paulo).

Trecho destacado a grafite na margem direita na leitura, de Lobato; referente à carência de leitura na Idade Média (Biblioteca Infantil Monteiro Lobato, São

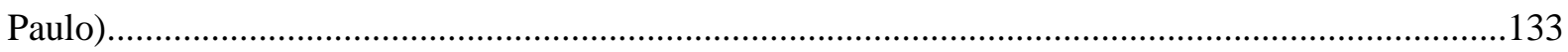

Notas de Lobato a grafite: quadriculado sobre a ilustração e indicação da apropriação a ser efetuada: "feita" e "Nilo" (Biblioteca Infantil Monteiro Lobato, São Paulo).

Ilustração reproduzida em História do mundo para as crianças....... 134

Nota de Lobato a grafite: linhas quadriculando a imagem e indicação "feita" (Biblioteca Infantil Monteiro Lobato, São Paulo).

Ilustração reproduzida em História do mundo para as crianças...

Nota de Lobato a grafite. Linhas quadriculando a imagem para reelaboração e indicação "feita" (Biblioteca Infantil Monteiro Lobato, São Paulo). 136

Ilustração reproduzida em História do mundo para as crianças. 136

Nota de Lobato a grafite. Linhas quadriculando a imagem e indicação "feita" (Biblioteca Infantil Monteiro Lobato, São Paulo).

Retrato de Fernão de Magalhães na História do mundo para as crianças.....

Ilustração com notas de Lobato a grafite revelando a apropriação. Indicações "feita" e "2 desenhos" (Biblioteca Infantil Monteiro Lobato, São Paulo).

Apropriação do retrato e da legenda em História do mundo para as crianças...... 138

Apropriação do retrato e da legenda em História do mundo para as crianças...... 138

Trecho destacado por anotação a grafite e a lápis azul na leitura/ criação de Lobato (Biblioteca Infantil Monteiro Lobato, São Paulo)... 139

Apropriação da imagem em História do mundo para as crianças.

Apropriação da imagem em História do mundo para as crianças.

Lobato corta de A Child's History of the World o nome de Nabucodonosor em escrita cuneiforme (Biblioteca Infantil Monteiro Lobato, São Paulo). 
Reprodução da imagem em História do mundo para as crianças.

Lobato corta de A Child's History of the World o nome de Cleópatra em hieróglifo (Biblioteca Infantil Monteiro Lobato, São Paulo).

Reprodução da imagem em História do mundo para as crianças.

Lobato corta de A Child's History of the World a imagem de Gutenberg ao lado de um prelo (Biblioteca Infantil Monteiro Lobato, São Paulo)

Reprodução da imagem em História do mundo para as crianças.

Lobato corta de A Child's History of the World a imagem de Shakespeare lendo para a rainha Elizabeth (Biblioteca Infantil Monteiro Lobato, São Paulo). 142

Reprodução da imagem em História do mundo para as crianças.

Cruzeta a grafite azul rasurada na leitura de Lobato (Biblioteca Infantil Monteiro Lobato, São Paulo)......

Anotação das datas "7/1/33" e "4/3/33" a grafite e lápis vermelho (Biblioteca Infantil Monteiro Lobato, São Paulo). 143

Conta traçada por Lobato a tinta vermelha em seu exemplar do livro de Hillyer (Biblioteca Infantil Monteiro Lobato, São Paulo). 


\section{Sumário}

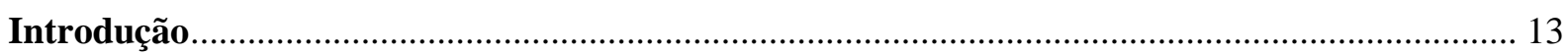

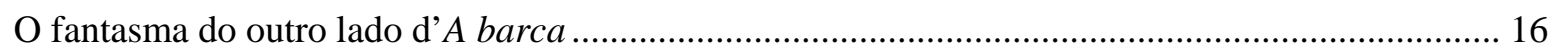

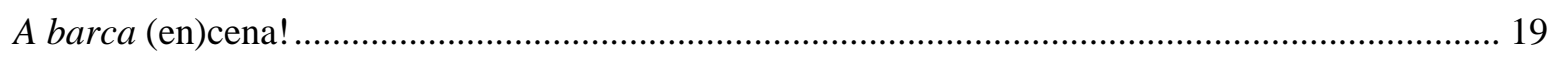

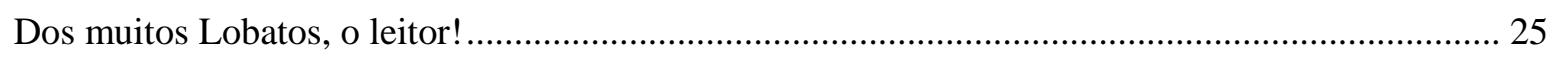

PARTE I..

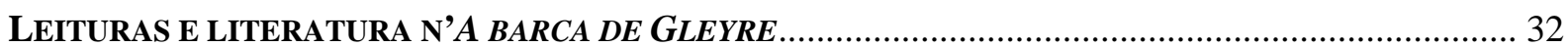

\section{Capítulo 1}

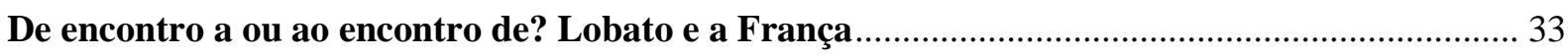

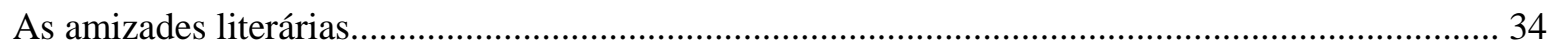

Outras relações por intermédio da literatura francesa ........................................................................ 48

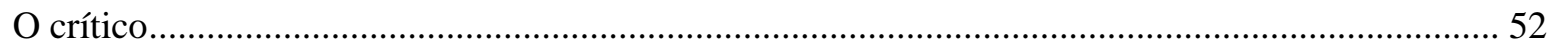

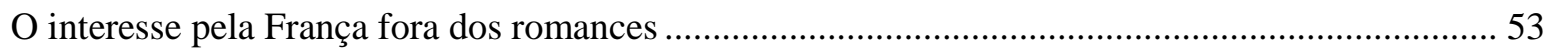

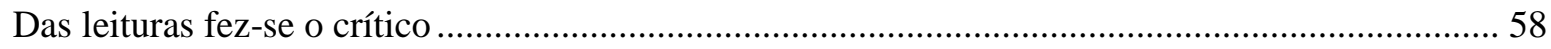

\section{Capítulo 2}

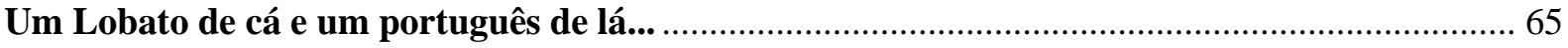

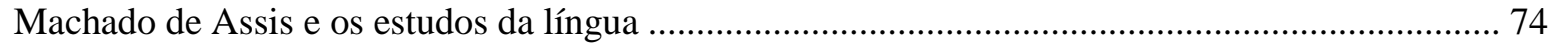

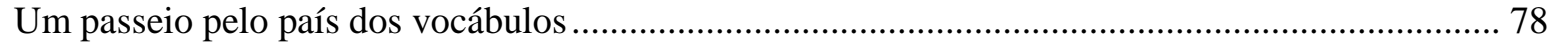

\section{Capítulo 3}

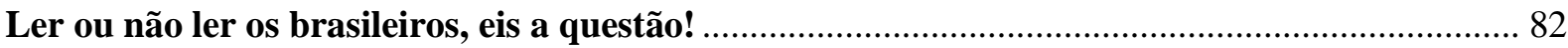

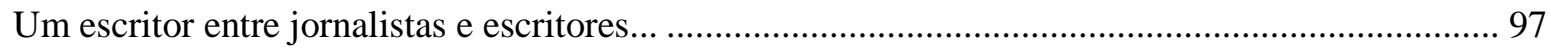

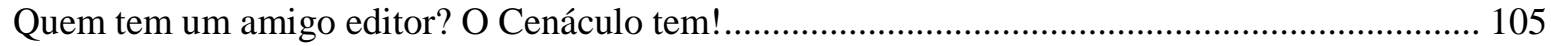

\section{Capítulo 4}

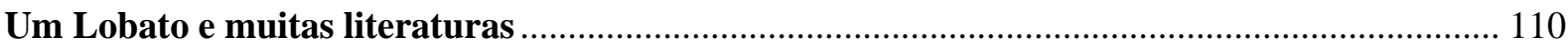

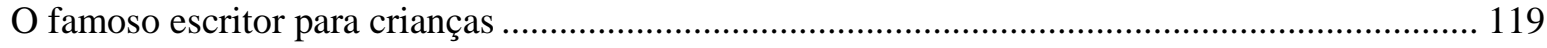




\section{PARTE II}

VESTÍGIOS DA BIBLIOTECA DE MONTEIRO LOBATO

Capítulo 1

Das cartas até a biblioteca do escritor 123

Um pouco de história antes da História!. 128

O manuscrito de História do mundo para as crianças 131

Considerações finais 146

Referências bibliográficas.

COMPLEMENTOS

Complemento A - Autores e obras citados por Monteiro Lobato entre 1903-1917 em A barca de Gleyre

Complemento B - Carta de Georgette Tavares Bastos à Editora Brasiliense Ltda.

Complemento C - Carta de Georgette Tavares Bastos à Ruth Monteiro Lobato

Complemento D - Texto de Monteiro Lobato

Complemento E - Tabela dos títulos publicados pela Revista do Brasil e pelas editoras Monteiro Lobato \& Cia., Cia. Graphico-Editora Monteiro Lobato e a Cia. Editora Nacional. 188

Complemento F - Livros traduzidos por Monteiro Lobato

Complemento G - Livros doados pela família à Biblioteca Infantil Monteiro Lobato após a morte do escritor

Complemento H - Livros que integram o Fundo Monteiro Lobato, da Unicamp 


\title{
Introdução
}

\begin{abstract}
"Minha correspondência geral é incrível. Tenho cartas de todo mundo importante desta terra e de outras. Se procurar bem, sou capaz de descobrir algum autógrafo do Pithecanthropus erectus..."
\end{abstract}

Monteiro Lobato ${ }^{1}$

Objeto de estudos em diversas áreas do conhecimento, a vasta correspondência de Monteiro Lobato (1882-1948) permite reunir diferentes perspectivas desse escritor que trocou cartas e bilhetes com parentes, amigos e intelectuais. Divide-se em correspondência ativa, passiva e de terceiros que, por alguma razão ficou, sob a custódia de Lobato.

Em A barca de Gleyre, livro que Lobato organiza e publica pela Companhia Editora Nacional em 1944, acha-se reunida somente a correspondência ativa endereçada ao amigo e escritor Godofredo Rangel (1884-1951); soma 340 cartas e dois bilhetes. Cobre o período 1903-1948, sendo o primeiro um bilhete sem data, dado como de 1903, e o último, uma carta de 23 de junho de 1948, doze dias antes da morte do remetente, encerrando mais de quarenta anos de conversa epistolar.

Na segunda edição, preparada novamente por Monteiro Lobato para figurar, em 1946, nas suas Obras completas pela Editora Brasiliense, não foram reproduzidas onze cartas, escritas entre 5 de março de 1945 e 10 de março de 1947. Na reedição, em 1948, a mesma casa paulistana repete a ausência que ela repara em 1950, na quarta edição. Em 2010, a Editora Globo põe nas livrarias A barca de Gleyre revista e acrescida de documentos.

Porém, antes de chegar às cartas, deve-se perguntar: como é que se ensaiam os primeiros passos dessa amizade?

Na cidade de Taubaté (SP), José Bento Monteiro Lobato nasce a 18 de Abril de 1882, filho de José Bento Marcondes Lobato e Olympia Monteiro Lobato. Passa a infância na cidade natal e, após a morte dos pais, é criado pelo avô materno, José Francisco Monteiro, Visconde de Tremembé. Em 1900, muda-se para a cidade de São Paulo, aprovado nos exames

\footnotetext{
${ }^{1}$ LOBATO, Monteiro. A barca de Gleyre. Edição coordenada por Arlete Alonso. São Paulo: Globo, 2010, p.559. Carta de São Paulo, 05/07/1943.
} 
da Faculdade de Direito do Largo de São Francisco, que frequenta até 1904. É neste espaço de tempo que conhece José Godofredo de Moura Rangel, seu correspondente.

Nascido na cidade mineira de Três Corações, a 21 de novembro de 1884, Rangel chega à capital paulista em 1902 para também cursar Ciências Jurídicas e Sociais no Largo de São Francisco. Entretanto, em 1904, passa a residir em Campinas, onde leciona por alguns meses, valendo-se da possibilidade de prosseguir no curso jurídico sem frequência integral. Falece de câncer em 4 de agosto de 1951, em Belo Horizonte ${ }^{2}$.

Com outros amigos, nem todos egressos do Largo de São Francisco, Lobato e Rangel formam o grupo autodenominado Cenáculo que se reúne, quase todas as noites, no Café Guarani, à rua 15 de Novembro, e na república estudantil do Minarete, chalé amarelo no Belenzinho. O crescimento das afinidades faz com que, em 1903, Lobato intime Rangel a ingressar no universo das cartas:

"Sigo logo para a fazenda e quero de lá corresponder-me contigo longa e minuciosamente, em cartas intermináveis - mas é coisa que só farei se me convencer de que realmente queres semelhante coisa.

"Mando um Estado com o discurso do Ramalho Ortigão, e o começo do meu Diário. E vai uma revista com capa minha.

"Responda sem demora se está disposto a ser caceteado à distânciatelecaceteado!"3

Repleta de pequenos objetos de sedução nas menções ao jornal, o texto e a revista, as cartas fisgam o destinatário. Como não se tem acesso à resposta de Rangel, é o próprio perdurar da correspondência que testemunha o pacto epistolar. Ao reconhecer que era pouco o tempo de convívio, a amizade mantida na ausência transfere para o diálogo das cartas a encenação de uma quase convivência, sendo o meio encontrado para se expressar e, principalmente, compartilhar o exercício literário. É interessante notar que o próprio Lobato distingue o Rangel amigo das cartas:

"Hoje vai cartapácio; estou de veia e com saudades. Dirás: 'Então por que não vens?'. É que este hábito de escrever-nos desdobrou-te em dois Rangéis: o de carne, professor, marido e lá sei que mais e o Rangel epistológrafo. Este é que é o meu. Deste é que conheço as ideias e manhas. Que fique com dona

\footnotetext{
${ }^{2}$ São aqui arroladas editoras e datas dos títulos de Godofredo Rangel: Estudo práctico de Português ([sl/sn], 1917); Vida ociosa (São Paulo: Monteiro Lobato \& Cia, 1920); Andorinhas. (São Paulo: Monteiro Lobato \& Cia, 1922); A filha (Belo Horizonte: Imprensa Oficial de Minas Gerais, 1929); Um passeio à casa de Papai Noel (São Paulo: Cia. Editora Nacional, 1943); Histórias do tempo do onça (São Paulo: Cia. Editora Nacional, 1943); Os humildes (São Paulo: Universitária, 1944); Os bem casados (São Paulo: Melhoramentos, 1955); Falange gloriosa (São Paulo: Melhoramentos, 1955).

${ }^{3}$ LOBATO, Monteiro. A barca de Gleyre. Ed. cit., p. 42. Carta de São Paulo, 09/12/1903.
} 
Bárbara $^{4}$ o primeiro. Eu só quero o segundo. Este é o Rangel longe - e bem sabes como o longe embeleza as coisas, faz a montanha, que é verde, parecer-nos azul; e torna também azul um céu de ar incolor. O meu Rangel e o de Bárbara! O dela é o marido, o professor, o gastrônomo, o dono de casa, o filho - o cidadão certamente muito igual a todos os outros maridos e professores e donos de casa etc. O meu é uma coisa que só eu sei, porque só a mim revela. É um que me manda todas as flores que lhe nascem no canteiro da inteligência, como diria o Praxedes de Abreu, um jornalista daqui profundamente imaginoso." ${ }^{5}$

O gosto máximo pela literatura marca os primeiros anos dessa conversa em mangas de camisa e pé no chão, como a denomina Lobato em sua carta de 7 de novembro de 1904. De modo recíproco, discorrem sobre leituras, criticam escritores e personalidades da época, trocam esboços e originais dos próprios textos, comentam a criação.

A chegada de uma nova carta entusiasma Lobato por lhe assegurar a possibilidade de diálogo com alguém cujas ideias são proximamente compatíveis com as suas:

"Tua carta veiu como aragem. Eu estava com saudades dum voo e aqui não há asas - só se discutem coronéis políticos e namoros. E eu estava cansado, esmagado pela genial estopada do maçante Zola no Travail; andava descontente comigo mesmo, com as minhas ideias, com estes miolos que quanto mais aprendem menos sabem, e a pensar na morte - todo ódios e invejas. Tua carta foi um sopro em queimadura. Vou responder longamente, porque enquanto escrevo as ideias-morcego não me perseguem; e vou dar largas ao meu magisterdixismo.

\section{$[\ldots]$}

"Tuas cartas me são um estimulante; obrigam-me a pensar, abrem-me perspectivas"6.

A barca de Gleyre dispõe as múltiplas facetas lobatianas. Ali está o jovem universitário que convive com o leitor de romances franceses, cujas leituras se diversificam para a construção do contista que estreia em 1918 com Urupês. A partir da compra da Revista do Brasil, Lobato enceta uma trajetória revolucionária na produção do livro no país. Cresce o intelectual engajado que soltará, bem mais tarde, a voz na campanha em defesa do ferro e do petróleo brasileiros.

\footnotetext{
${ }^{4}$ Bárbara Pinto de Andrade, esposa de Godofredo Rangel.

${ }^{5}$ LOBATO, Monteiro. A barca de Gleyre. Ed. cit., p. 112. Carta de Taubaté, 1906.

${ }^{6}$ IDEM, ibidem, p. 55. Carta de Taubaté, 20/01/1904.
} 


\section{$\underline{\text { O fantasma do outro lado d'A barca }}$}

Conhecidas nossas são as cartas de Monteiro Lobato. Entretanto, há sempre algumas perguntas que são levantadas ao redor dessa amizade escrita: $\mathrm{O}$ que aconteceu com as cartas de Godofredo Rangel? Por que elas não foram publicadas? Estas cartas existem de fato? Se existem, com quem estão?

As respostas são diversas e trazem hipóteses que deixam muitas vezes os leitores e pesquisadores da correspondência lobatiana diante de questões próprias da genética epistolar. No ensaio "Qual genética para as correspondências?”, José-Luis Diaz refere-se às cartas "fantasmas":

"Em matéria epistolar, os fantasmas são as cartas hoje perdidas, que não possuem senão uma existência hipotética, mas cuja presença virtual se deduz, certamente, através de outras cartas que fundamentam sua existência - seja pela simples alusão, seja às vezes por citações."

Constituirão um verdadeiro caso de fantasma epistolar as cartas de Godofredo Rangel a Lobato? Eis que parte dessa obscuridade é iluminada nas páginas de um periódico mineiro, em 1984. Organizados por Márcio Sampaio, dois números especiais do Suplemento Literário do jornal oficial daquele Estado, o Minas Gerais ${ }^{8}$, em 24 de novembro e $1^{\circ}$ de dezembro, são dedicados a Godofredo Rangel como homenagem ao escritor no ano de seu centenário. Por meio da transcrição de artigos críticos, depoimentos de amigos e familiares, capítulos de romances, contos, além de material inédito como trechos de obras e dezessete das tão aguardadas cartas a Monteiro Lobato, o Suplemento delineia aspectos da vida deste escritor que também foi tradutor, professor e juiz.

A não publicação das cartas é assunto desde as primeiras páginas do Suplemento Literário de 24 de novembro, 1984, ao oferecer o artigo "Godofredo Rangel”, em verdade

\footnotetext{
${ }^{7}$ DIAZ, José-Luis. "Qual genética para as correspondências”. Trad. Cláudio Hiro e Maria Sílvia Ianni Brasalini. Manuscrítica. Revista de Crítica Genética, no 15. São Paulo: Humanitas, 2007, p. 129.

${ }^{8}$ Como consta do histórico, o Suplemento Literário, quando criado, na década de 1960, sob a responsabilidade da Imprensa Oficial, saía semanalmente como encarte do jornal institucional do Estado, o Minas Gerais, o que durou até 1992. Interrompido em 1993, voltou a ser editado um ano depois, sob a chancela da Secretaria de Estado da Cultura, com o título simplificado para Suplemento, com periodicidade mensal e nova numeração. Os primeiros redatores foram os escritores mineiros Murilo Rubião, Laís Correa de Araújo e Ayres da Mata Machado Filho. O projeto Suplemento Literário - Preservação, desenvolvido, desde 1997, pela Biblioteca da Faculdade de Letras (Fale) da UFMG, tornou disponível uma versão eletrônica do Suplemento, por meio da digitalização e microfilmagem do acervo de 1966 a 2004, constituído de 1282 fascículos. Disponível através do endereço eletrônico http://www.letras.ufmg.br/websuplit/Lib/html/WebSupLit.htm.
} 
uma parcela da biografia do escritor, escrita por Enéas Athanázio 9 . Mesmo lançando seus livros e tendo boa repercussão na crítica, Rangel permanecia tímido e expressava esse acanhamento diante de uma possível publicação de suas cartas. Após ter sugerido que Lobato publicasse as próprias cartas e as reunisse n'A barca de Gleyre, ainda que em meio a tantos pedidos, não franqueia as suas missivas e proíbe o filho, Nello de Moura Rangel, de fazer isso $^{10}$.

Uma das razões referidas para a não publicação é que Godofredo Rangel julgava as próprias cartas sem interesse especial quanto ao conteúdo, entendendo que apenas provocavam as excelentes respostas de Lobato. Por essa razão, o plano original de editar a correspondência recíproca fora preterido e o prefácio d'A barca de Gleyre tornara-se tarefa para Edgard Cavalheiro:

"Minha ideia no começo era dar as tuas e as minhas [cartas] juntas, articuladas, mas vi que isso iria estragar tudo. Para quem está de fora, tem muito mais interesse uma conversa telefônica da qual só ouve um lado; o fato de não ouvir o outro lado força mais a imaginação. Fica um imenso campo de colaboração aberto à imaginativa do auditor. Solto agora as minhas cartas a você; e depois você solta as tuas a mim."11

Posteriormente à primeira edição d'A barca, o próprio Lobato pleiteia a publicação das cartas de Rangel e tenta convencê-lo do sucesso que seria:

"E as cartas, meu Godo? Continuam a reclamá-las. Deixa-te de enjoamentos e organize-as, como fiz com as minhas. Todo comprador da Barca fatalmente comprará as tuas.

"Não vês isso animal? Ganharás no mínimo (edição de cinco mil) uns 20 contos." $" 12$

A recusa de publicar, afetando não só as cartas, mas também de parte da obra, perpassa a vida de Rangel, como testemunha A barca de Gleyre, onde vemos a insistência de Lobato em divulgar contos e romances do amigo. O biógrafo Enéas Athanázio analisa:

"Monteiro Lobato, o amigo e confidente, o 'buldogue' da Cainçalha, chegou ao auge da fama literária. Tornou-se extremamente popular, viveu em São Paulo, no Rio de Janeiro e em Nova Iorque. Ele [Rangel], porém, vegetou em pobres vilocas interioranas, mais ou menos desconhecidas. Não há dúvida, entretanto, que contribuiu para essa situação. Nunca se promoveu

\footnotetext{
${ }^{9}$ Cf. ATHANÁZIO, Enéas. Godofredo Rangel. Curitiba: Gráfica Editora, 1977.

${ }^{10}$ IDEM. "Godofredo Rangel”. In: Suplemento Literário do Minas Gerais. Belo Horizonte, a. 19, n 947,24 nov. 1984, p. 4.

${ }^{11}$ LOBATO, Monteiro. A barca de Gleyre. Ed. cit., p. 565. Carta de São Paulo, 27/10/1943.

${ }^{12}$ IDEM, ibidem, p. 573. Carta de São Paulo, 26/12/1945.
} 
ou procurou propagar o próprio nome e a sua obra. Contentava-se, parece, com a posição de "outro lado" do célebre taubateano."13

Márcio Sampaio, no texto “A outra barca”, não só enaltece Rangel como também traz algumas informações acerca dos rumos tomados pelo arquivo do escritor:

"Aconselhando os filhos que queimassem seus papéis - rascunhos, esboços, tudo que ficara como massa ainda informe de sua literatura, bem como as cartas que, ao longo de quatro décadas, escrevera a Lobato, 'por se tratarem de coisas sem valor literário' - Godofredo Rangel dava, ao morrer, mais uma prova de sua proverbial modéstia. [...].

"Mas, mineiramente, com esse débil brilho de esperança, abre-se uma brecha que garante a sobrevivência do legado do escritor para o quadro do patrimônio cultural brasileiro: ele próprio, em uma nota afixada na pasta de suas cartas a Lobato, deixa a critério dos filhos a seleção daquilo que lhes parecer literariamente relevante." ${ }^{\prime 14}$

O trecho é exemplar para discutir questões relativas à publicação de cartas, ao envolvimento de familiares em decisões a serem tomadas acerca dos rumos da correspondência e, até mesmo, à relevância da divulgação de uma conversa epistolar entre amigos. Ademais, no caso das cartas de Rangel não publicadas, quais foram os critérios adotados para selecionar aquilo que "pareceria literariamente relevante"? Enfim, querelas à parte, é Philippe Lejeune, em "A quem pertence uma carta", que adverte: "mesmo postada, a carta continua sendo, intelectual e moralmente, propriedade de seu autor - e, depois de sua morte, de seus herdeiros, que são os únicos que podem autorizar a publicação."15

Fato é que as cartas não saíram n'A barca e até hoje são objetos do desejo de muitos pesquisadores. Contudo, o Suplemento Literário, em 1984, garantiu o acesso a dezessete cartas, até então inéditas, de Rangel para Lobato. Escritas entre 1905-1948, de diferentes cidades - São Paulo, Caldas, Silvestre Ferraz, Campinas, Três Pontas, Belo Horizonte ocupam-se, principalmente, do cotidiano de Rangel, de suas leituras e produção literária.

\footnotetext{
${ }^{13}$ ATHANÁZIO, Enéas. "Godofredo Rangel”. In: Suplemento Literário do Minas Gerais. Belo Horizonte, a. 19, n ${ }^{\circ}$ 947, 24 nov. 1984, p. 4.

${ }^{14}$ SAMPAIO, Márcio. "A outra barca”. In: Suplemento Literário do Minas Gerais, Belo Horizonte, ano 19, n. $948,1^{\circ}$ dez. 1984 , p. 8.

${ }^{15}$ LEJEUNE, Philippe. "A quem pertence uma carta?" In: NORONHA, Jovita Maria Gerheim (org.). O pacto autobiográfico: de Rousseau à Internet. Trad. Jovita Maria Gerheim Noronha e Maria Inês Coimbra Guedes. Belo Horizonte: Editora UFMG, 2008, p. 253.
} 


\section{$\underline{\text { A barca }(\mathrm{en}) \mathrm{cena} !}$}

"Poucas correspondências haverá como a nossa, tão longa e tão fora do mundo."

Monteiro Lobato ${ }^{16}$

Ao tomar a correspondência reunida em A barca de Gleyre como a principal fonte desta pesquisa para o mestrado, foi necessário compreender que as cartas não foram, aparentemente, escritas com o objetivo de serem publicadas, tendo, a uma primeira leitura, a finalidade de permitir a comunicação entre dois amigos. Será, então que elas podem ser consideradas fiéis "portadoras" de pensamentos e intenções do autor?

A veracidade documental das cartas é sempre um assunto a ser discutido. A primeira edição de A barca de Gleyre sai em 1944, preparada por Lobato, o que remete a alguns aspectos intrínsecos das edições de cartas. Na parte intitulada "Escusatória", é ele próprio quem apresenta a coletânea como uma "curiosidade editorial", e levanta questões que frequentam o universo dos estudos do gênero epistolar:

"Estas cartas se salvaram, das que escrevi a Godofredo Rangel no dilatado espaço de quarenta anos. Quarenta anos do mesmo amigo e mesmo assunto, que fidelidade!... E a consequência foi se tornarem uma raríssima "curiosidade". Não sei em nenhuma literatura de tão longa correspondência, sobre o mesmo assunto, entre só dois sujeitos.

"O gênero 'carta' não é literatura, é algo à margem da literatura... Porque literatura é uma atitude - é a nossa atitude diante desse monstro chamado Público, para o qual o respeito humano nos manda mentir com elegância, arte, pronomes no lugar e sem um só verbo que discorde do sujeito. $\mathrm{O}$ próprio gênero 'memórias' é uma atitude: o memorando pinta-se ali como quer ser visto pelos pósteros - até Rousseau fez assim - até Casanova.

"Mas cartas não... Carta é conversa com um amigo, é um duo - e é nos duos que está o mínimo de mentira humana. Ora, como da minha conversa escrita com Rangel se salvassem quase todas as cartas, tive ensejo um dia de lê-las - e sinceramente achei que constituíam uma 'curiosidade editorial' de bom tamanho. E que teriam interesse para o público justamente porque ao escrevê-las nunca me passou pela mente que jamais fossem dadas a público. Mas vacilei. Dá-las ou não? Tão íntimo tudo aquilo. Tantas perversidadezinhas para com os amigos, tanta piada para cima do Nogueira o companheiro que no fundo mais admirávamos... Além de que isso de cartas é sapato de defunto. Depois que o autor morre é que elas aparecem.

\footnotetext{
${ }^{16}$ LOBATO, Monteiro. A barca de Gleyre. Ed. cit., p. 381. Carta da Fazenda, 05/11/1916.
} 
"Pensei, pensei, pensei. Por fim, vá lá. Tenho sérias dúvidas sobre se estou ainda vivo - e se as cartas saírem com a minha revisão de semivivo, apresentar-se-ão podadas de muitas inconveniências que um semimorto já não subscreve."17

Lobato é perspicaz quando alude ao personagem de Memórias póstumas de Brás Cubas, de Machado de Assis, para confessar sua revisão de "semivivo" com a finalidade de publicar as cartas. Testemunha-se em diversas passagens n'A barca o processo de preparar a correspondência para publicação em livro:

"Falas tanto nas minhas cartas que estou na suspeita de que se enchem de coisas boas pelo caminho. Chegas a insistir na absurda ideia da publicação! Estou curioso de relê-las e verificar que enxertos são esses, tão do teu agrado. Se eu fosse o Frango Sura ou outro qualquer dos muitos que te desconhecem a sutilíssima ironia, era provável que me iludisse. Mas conheço-me e também te conheço, meu tranca. E digo como o malandro: 'Não brinca, mano'. Dois quilos de cartas. Quanto nonsense nelas, quanto sonhinho tolo! Mas desempenharam uma grande missão. Com o trocá-las anos a fio, e escrever-nos virou-nos hábito, e bom hábito - e a vida é uma sedimentação de hábitos."18

"Reli as cartas minhas que mandaste, e que saudades tive do que já lá vai nesses treze anos de palestra pelo correio! Saudades... Pela primeira vez ponho aqui esta palavra. E sabe o que no fundo quer isso dizer? Velhice [...] Façamos de nossas cartas duas cópias a máquina bem batidinhas, em bom papel, para as relermos na velhice. São, afinal de contas, as nossas memórias íntimas - mas memórias só para nós. Nem nossos filhos entenderão o que fomos um para o outro."19

"Que ideia sinistra a tua, de publicarmos as minhas cartas! Seria dum grotesco supremo, porque cartas só interessam ao público quando são históricas ou quando oriundas de, ou relativas a, grandes personalidades. No nosso caso não há nada disso: não são históricas e nós não passamos de dois pulgões de roseira - eu, um pulgão publicado; você, um pulgão inédito. $O$ interesse que achas nas tais cartas é o interesse da coruja pelas peninhas dos seus filhotes. Formam um álbum de instantâneos da nossa vida. Mas o público quer penas de pavão, plumas de avestruz ou aigrettes de garça não quer peninhas de filhote de coruja. Todos iriam rir-se de nós, além de que estão cheias de maldadezinhas endereçadas a amigos e conhecidos, sobretudo por mim, que tenho a mania de arrasar tudo, a começar por mim mesmo. Não. Varra com a ideia." 20

"Fui mexer na minha tremenda papelada epistolar e tonteei. É coisa demais. É um mundo. Pus a Ruth ${ }^{21}$ separando aquilo e classificando por ordem de data - é o primeiro passo. O segundo será separar certas cartas, como as tuas, que são as mais numerosas; e como por milagre tenho aqui as minhas, estou vendo que desse passo vai sair coisa grossa e talvez muito interessante. Desconfio, Rangel, que essa nossa aturada correspondência vale

\footnotetext{
${ }^{17}$ LOBATO, Monteiro. "Escusatória”. In: A barca de Gleyre. Ed. cit., p. 31.

${ }^{18}$ IDEM, ibidem, p. 378. Carta da Fazenda, 29/10/1916.

${ }^{19}$ IDEM, ibidem, p. 380-1. Carta da Fazenda, 05/11/1916.

${ }^{20}$ IDEM, ibidem, p. 440. Carta de São Paulo, 26/05/1919.

${ }^{21}$ Ruth Monteiro Lobato, filha de Lobato e Purezinha.
} 
alguma coisa. É o retrato fragmentário de duas vidas, de duas atitudes diante do mundo - e o panorama de toda uma época. Literatura, história e mais coisas. [...] Bom. Esta vai apenas para te comunicar que meti mãos á mina. Quando estiver tudo datilografado, você vai se assombrar, e verificar que éramos muito mais interessantes nos bastidores epistolares do que no palco e juntos penetraremos na posteridade $\left[\ldots . .,{ }^{, 22}\right.$

"Achei ótima a ideia de você mesmo bater na máquina as tuas cartas. Farei isso às minhas, e assim as depuraremos dos gatos, do bagaço, das inconveniências. Deixaremos só o bom - como as canas de chupar que a gente atora a ponta e o pé. Depois decidiremos sobre o que fazer. Imagine uma edição de Cartas Nossas em dois ou três volumes, coisa que nunca foi feita neste país!

"Não posso formar opinião definitiva antes da datilografagem de tudo, da poda das pontas e pés e da 'limpeza' raspagem da cana. Numa das tuas há uma pequenina confissão que se sair impressa te deixa raso aí em Belo Horizonte. Aquela historia do...,23

Se no início a ideia de publicar as missivas parecia absurda, com o tempo, Lobato pensa mais sobre o assunto e o projeto se dimensiona. As cartas que, considerando o meio da escrita, são originalmente autógrafos a tinta, recebem transcrição datilografada para melhor avaliação do conteúdo e ajustes para a gráfica. O remetente brinca com a preservação de momentos atinentes à esfera íntima e confessional das cartas quando reconhece a necessidade de "poda das pontas e pés" e da "raspagem da cana", o que constitui, em verdade, a operação editorial $^{24}$.

A filha de Lobato, Ruth, o auxilia na organização cronológica. As cartas, relidas por Lobato e Rangel, contam também com outros leitores que estimulam a publicação. Recebem o aval do futuro biógrafo do escritor, Edgard Cavalheiro:

"Estou quase me apaixonando pela obra. As cartas são os andaimes; as notas
completam-nas. Creio que não há em literatura nenhuma uma série tão longa
de cartas entre duas vocações, sempre sobre o mesmo assunto e no mesmo
tom. O Edgard Cavalheiro aprovou-as com calor, achando que dá um livro
dos mais originais. Fizemos também uma prova feminina - e a julgadora
disse ao Edgar: "Comecei a ler e não parei - terminei a leitura de madrugada;
e estou a reler várias cartas'."25

Se n'A barca de Gleyre temos a perspectiva de Monteiro Lobato quanto à publicação, a de Rangel é ali apenas é inferida. Nesse sentido, o Suplemento Literário, em duas das cartas inéditas, traz a opinião de Rangel sobre a organização da correspondência. Em 15 de outubro de 1916, ele escreve:

\footnotetext{
${ }^{22}$ LOBATO, Monteiro. A barca de Gleyre. Ed. cit., p. 558-9. Carta de São Paulo, 05/09/1943.

${ }^{23}$ IDEM, ibidem, p. 560. Carta de São Paulo, 15/09/1943.

${ }^{24}$ IDEM, ibidem, p. 560. Carta de São Paulo, 15/09/1943.

${ }^{25}$ IDEM, ibidem, p. 565. Carta de São Paulo, 27/10/1943.
} 
"Acabei de ordenar mais ou menos tuas cartas. Fazem um pacote de uns dois quilos. Impressos, dariam uns cinco volumes à Charpentier. Cá estão ao teu dispor. Foi meu compêndio de estética. Você e o Ricardo foram os meus dois iniciadores, você tem continuado o que ele encetou, arrancando-me da mão romances de fancaria e orientando-me o gosto pela boa leitura. Tuas cartas são um curso completo, e mais uma vez te lembro que ali tens massa para um livro de arte maciça, condensada, além de outros de prosa leve, que seduzem pela naturalidade do dizer, aliada à sutileza do conceito - segredo que Anatole possui tão bem e que mais ganham como coleção de cartas. Se escrevesses um romance em cartas farias uma nova Mlle. de Maupin que peca por ser mais romance que epístolas, se é que neste romance pode haver algo frágil." 26

É através do diálogo desta carta com aquelas n'A barca de Gleyre, principalmente com a de 29 de outubro, 1916, que, de fato, se entende a publicação como ideia de Godofredo Rangel, ao reunir e ordenar os dois quilos de cartas. É também o mineiro quem lhes chancela o valor literário, em 21 de novembro de 1917:

"Daqui uns tempos, se tiver pachorra e houver encontrado um bom plano de coordenação, quero ver se tiro um livro teu das tuas cartas. Manda-mas logo que possas, que preciso delas para rever algumas velhas coisas que me interessam. Creio que é legítima velhice esse gosto de reler e mexer em papéis velhos... Ou será sintoma de cabeça assentada. Quando a gente se desilude de esperar belas coisas do Futuro, vê que essas belas coisas já nos passaram despercebidas entre as mãos sôfregas: volvemos então a remexer no bric-à-brac do passado, onde encontramos o melhor do que buscávamos. Mas já é muito misticismo para uma só carta."27

A definição da carta como partilha coincide com o escopo da correspondência Lobato e Rangel. Através dos trechos selecionados, pode-se observar que as cartas chegam aos destinatários; passa-se um tempo e, para serem relidas, até mais de uma vez, voltam aos respectivos remetentes.

Naquela mesma carta de 15 de outubro de 1916, enquanto sugere a publicação das cartas do amigo, Rangel já parece mostrar o pouco valor que dá à sua própria correspondência; lembra ter queimado as cartas de amor endereçadas à esposa:

"Quis tentar esta seleção em minhas cartas de amor - vi porém que o gênero não se prestava, dado o estado de estupidez e, que fica atacado o correspondente, e acabei, depois de relidas à Bárbara, para renovação de estudos d'alma antigos, e acabei por fazer delas um fogueirão, que não deflagrou menos intensamente que a labareda que as incendiava interiormente (...). ${ }^{, 28}$

\footnotetext{
${ }^{26}$ Carta de Godofredo Rangel a Monteiro Lobato. Suplemento Literário do Minas Gerais, Belo Horizonte, ano $19, \mathrm{n}^{\circ} .948,1^{\circ}$ dez. 1984, p. 10 . Transcrição da carta de 15/10/1916.

${ }^{27}$ IDEM, ibidem, p.10. Transcrição da carta de 21/11/1917.

${ }^{28}$ IDEM, ibidem, p.10. Transcrição da carta de 15/10/1916.
} 
Enfim, como se vê, existe nos carteadores a preocupação de construir, de "encenar" as respectivas figuras, não dando azo às correções alheias ou à maledicência. É interessante pensar que o criador de Emília não esconde a re-escritura visando à publicação, diferenciando e protegendo a privacidade original da interlocução. Observa-se que nosso escritor tinha certa familiaridade com gêneros da escrita do eu, referindo-se n'A barca às memórias de Casanova, às cartas do Padre Antônio Viera e à correspondência de Taine. Na missiva de 30 de setembro de 1915, Lobato discute sua preferência:

"Já notaste como é mais vivo o estilo das cartas do que o de tudo quanto visa aparecer em livro ou jornal? Acho maravilhoso o prime saut das cartas. [...] A caraça do público, a 'feição' do jornal, os moldes do editor, sempre antepostos aos nossos olhos quando 'escrevemos para imprimir', acanhamnos a expressão, destroem-nos a alerteza do élan. Eu, por mim, só lia cartas e memórias como as do Casanova." 29

Além disso, ao apresentar questões relacionadas à organização das cartas e ao preparo da edição, Lobato assume praticamente o papel de um geneticista, se nos reportamos a Almuth Grésillon: "Sem dúvida os escritores, quando falam de sua própria atividade, são eles próprios os primeiros geneticistas." ${ }^{30}$ Aliás, vale notar que A barca de Gleyre abona o processo de criação de vários textos lobatianos.

Sabe-se que, no trabalho com cartas ou outros escritos de origem pessoal, nem sempre se tem a fidelidade garantida pelos documentos originais. Entretanto, até mesmo a leitura de documentos primários deve ser consciente das delimitações próprias a cada situação da escrita. Ao discutir a relação do texto com o real, Roger Chartier, em A história cultural: entre práticas e representações, alerta: "O texto, literário ou documental não pode nunca anular-se como texto, ou seja, como um sistema construído consoante categorias, esquemas de percepção e de apreciação, regras de funcionamento, que remetem para as suas próprias condições de produção" 31 .

É preciso sempre desconfiar! Ao reler a própria correspondência, o Lobato de 1943 admite ter construído a imagem que queria passar de si durante a juventude:

"Numa das minhas cartas, que peguei ao acaso, encontro esta nota: 'Estou escrevendo na Tribuna, de Santos, jornal cor-de-rosa, a 10 mil-réis o artigo.

\footnotetext{
${ }^{29}$ LOBATO, Monteiro. A barca de Gleyre. Ed. cit., p. 332. Carta da Fazenda, 30/09/1915.

${ }^{30}$ GRÉSILLON, Almuth. Devagar obras. Tradução de Júlio Castañon Guimarães. Rio de Janeiro, Fundação Casa de Rui Barbosa/ Ministério da Cultura, 1999. In: ZULAR, Roberto. Criação em processo: ensaios de crítica genética. São Paulo: FAPESP/Iluminuras, 2002, p. 153.

${ }^{31}$ CHARTIER, Roger. A história cultural: entre práticas e representações. Tradução de Maria Manuela Galhardo. Lisboa: Difel, 1990, p. 63.
} 
Mandei para lá hoje o 'Bocatorta'. Desconfio que falei em '10 mil-réis' para te dar inveja, pois tenho uma vaga ideia de que realmente só me pagavam 5. Está aí um ponto que qualquer criticastro do futuro resolverá com a maior segurança - e no entanto eu, que afirmei os 10 mil-réis, sou obrigado a deixar o ponto em obscuro. Talvez eu falasse em 10 mil-réis porque para todos nós naquele tempo ganhar 10 mil-réis com um piolho extraído do cérebro devia ser um sonho de grandeza - e de todos do Cenáculo era talvez eu o primeiro a alcançar a extraordinária bonanza. Haveria em nosso grupo outro que estivesse ganhando tanta coisa, ou com possibilidades de ganhar tanto, com os piolhinhos cerebrais?"32

Assim sendo, a questão da "veracidade" do gênero epistolar, embora sempre no horizonte deste trabalho, não o inviabiliza, uma vez que não se pretende discutir se as cartas são totalmente verídicas ou encenações; vamos apenas tomá-las como um recorte da realidade que o remetente quer mostrar a seu destinatário. Ou ao seu público, no livro.

É do conhecimento geral que o trabalho com cartas tem despertado o interesse de pesquisadores das mais diversas áreas. Para Giselle Martins Venâncio,

"A revalorização dos arquivos e da experiência individual fizeram com que as cartas - vestígios brutos de diálogos passados - emergissem como objeto privilegiado para a investigação histórica. Não mais a correspondência como um texto de onde se podiam simplesmente extrair informações, mas as cartas analisadas a partir de seu suporte material, dos códigos sociais utilizados e das formas lingüísticas empregadas" ${ }^{\text {,33. }}$.

Logo, muitas são as possibilidades de estudo que se abrem diante de uma correspondência tão vasta como a de Lobato, que trocou cartas com uma grande variedade de pessoas de sua época, desde sua esposa Purezinha; amigos, editores, escritores e intelectuais, até o então Presidente da República, Getúlio Vargas (1882-1954), com quem polemizou sobre a questão do petróleo no Brasil (acabou sendo preso). A rede de relações estabelecida por meio da epistolografia indica que "A teia de correpondência de um intelectual permite vislumbrar a tessitura de sua rede pessoal e profissional e, através dela, pode-se caracterizar suas práticas de intercâmbio de idéias, de troca de livros e de divulgação de suas opiniões."34

Em se tratando d'A barca de Gleyre, qual recorte fazer diante de tantas perspectivas que a correspondência possibilita?

\footnotetext{
${ }^{32}$ LOBATO, Monteiro. A barca de Gleyre. Ed. cit., p.559. Carta de São Paulo, 05/09/1943.

${ }^{33}$ VENÂNCIO, Giselle Martins. "Cartas de Lobato a Vianna: uma memória epistolar silenciada pela história". In: GOMES, Angela de Castro (org). Escrita de si, escrita da história. Rio de Janeiro: Editora FGV, 2004, p.113.

${ }^{34}$ IDEM, ibidem, p.114.
} 


\section{Dos muitos Lobatos, o leitor!}

"Literatura é cachaça. Vicia. A gente começa com um cálice e acaba paud'água de cadeia."

Monteiro Lobato ${ }^{35}$

A estreita relação Monteiro Lobato e livros é algo muito anterior às atividades de ficcionista, editor, tradutor e crítico. Na verdade, é como leitor que durante a juventude ele sonha ser literato; na época em que atua no mercado editorial, seu faro de leitor é utilizado para perceber obras que serão sucesso entre o público; enquanto tradutor, é o leitor que mergulha na obra de outrem para trazê-la para a língua de seu país; é ainda como leitor de textos infantis que sente a necessidade de uma literatura voltada para as crianças brasileiras. Esses são alguns dos possíveis diálogos quando se pensa na faceta Lobato leitor, lembrando que as referências são ainda muito mais se pensarmos na quantidade de obras lidas ao longo de sua vida.

O prazer pela leitura é provável que tenha se despertado na infância. Eliane Santana Dias Debus, na tese O leitor, esse conhecido: Monteiro Lobato e a formação de leitores, conta que o primeiro livro de leitura de Lobato foi João Felpudo, presente da mãe Dona Olímpia, quando ele tinha cinco anos de idade ${ }^{36}$. Aliás, segundo Edgard Cavalheiro, a leitura era um dos divertimentos preferido do menino, embora não houvesse muitos títulos para crianças naquele tempo:

"Ele conseguira reunir uns poucos, que lia e relia: três obras de Laemmert, adaptadas por Jansen Müller, e dois álbuns de cenas coloridas $O$ menino verde e João Felpudo. Havia ainda o Robinson resumido e certo livro de narrativas ingênuas intitulado Dez contos, incansavelmente lidos e relidos. Esse último, ele o perdeu no Jardim Público, certa tarde., ${ }^{, 37}$

Mas é o Lobato de 1904 quem nos conta as lembranças e descobertas vividas na biblioteca do avô Visconde de Tremembé:

"A biblioteca de meu avô é ótima, tremendamente histórica e científica. Merecia uma redoma. Imagina que nela existem o Zend-Avesta, o

Mahabarata e as obras sobre o Egito de Champollion, Maspero e Breasted; e

\footnotetext{
${ }^{35}$ LOBATO, Monteiro. A barca de Gleyre. Ed. cit., p. 64. Carta de São Paulo, 16/06/1904.

${ }^{36}$ DEBUS, Eliane Santana Dias. O leitor, esse conhecido: Monteiro Lobato e a formação de leitores. Tese de Doutorado (orientação: Regina Zilberman). Porto Alegre: Pontifícia Universidade Católica do Rio Grande do Sul, 2001, p. 37.

${ }^{37}$ CAVALHEIRO, Edgard. Monteiro Lobato: vida e obra. São Paulo: Cia Editora Nacional, 1955, p. 26.
} 
o Larousse grande; e o Cantù grande; e o Élysée Reclus grande; e inúmeras preciosidades nacionais, como a coleção do Journal des Voyages que foi o meu encanto em menino. Cada vez que naquele tempo me pilhava na biblioteca do meu avô, abria um daqueles volumes e me deslumbrava. Coisas horríveis, mas muito bem desenhadas - do tempo da gravura em madeira. Cenas de índios sioux escalpando colonos. E negros achantis de compridas lanças, avançando contra o inimigo numa gritaria. Eu ouvia os gritos... E coisas horrorosas da Índia. Viúvas na fogueira. Elefantes esmagando sob as patas a cabeça de condenados. E tigres agarrados à tromba de elefantes. E índios da Terra do Fogo, horríveis, a comerem lagartixas vivas. E eu via a lagartixa bulir... E tragédias do centro da Ásia e lá das Guianas. O rio Orinoco me impressionava muito. Eram os romances de aventuras de Gustave Aimard e Mayne Reid. Certa vez encontrei naquela biblioteca um álbum de fotografias que me tumultuaram o sangue: só mulheres nuas!... Mas não eram mulheres nuas, Rangel: eram nus do Salon. Eu não sabia distinguir. Também encontrei lá todas as obras de Spencer. Essa biblioteca, pela maior parte, fora dum filho de meu avô que depois de formar-se em São Paulo deu de correr mundo, andou pelo Egito e outros países históricos, apanhou febre na campanha romana e morreu num hotel de Nápoles. Secretário de legação. Sua bagagem veio para Taubaté, com os mais preciosos e curiosos livros comprados aqui e ali." ${ }^{38}$

É interessante observar que o Lobato que se encantava com as histórias quando menino reconhece, anos mais tarde, a necessidade de uma literatura voltada para a criança brasileira. Com as aventuras do Sítio do Picapau Amarelo, não só os pequenos puderam se deliciar, muitos adultos também!

Além da biblioteca do avô apresentar uma considerável variedade de títulos, Monteiro Lobato deixa pistas, em A barca de Gleyre, de que frequentou os clássicos e obras que eram conhecidas e lidas em sua época. Principalmente, durante a juventude, testemunha-se nas cartas a imagem de um Lobato em formação, leitor voraz que ensaia seus passos como escritor. Nos primeiros anos da conversa escrita, mostram-se as profusas e variadas leituras que lhe integram o cotidiano; na carta de dezembro de 1903, confia a Rangel:

"Leio, leio interminavelmente. Meus olhos já estão cansados. Lamartine me faz ver a Revolução Francesa [...] Quando Lamartine me cansa, mudo-me para Zola na história de Gervaise Coupeau, dos invejosos Lorilleux, da promissora Nanázinha. [...] Farto de Zola, pulo para Michelet na sua visão da Índia primitiva; ele começa bem mas entusiasma-se a ponto de dar pinotes; e eu, assustado, fecho o livro -fecho a boca de Michelet. Vou então para Renan - o sereno evocador da verdade. Renan é água clara e filtrada. Descansa-me. [...]"39

Ao mesmo tempo em que as leituras lhe ocupam um importante espaço, Lobato admite que não lê por obrigação, lição esta que ensina ao amigo na carta de 10 de janeiro de 1904:

\footnotetext{
${ }^{38}$ LOBATO, Monteiro. A barca de Gleyre. Ed. cit., p.55-6. Carta de Taubaté, 20/01/1904.

${ }^{39}$ IDEM, ibidem, p.48. Carta de Taubaté, 28/12/1903.
} 
"Perguntas quantas horas 'literatizo'. Nem uma, meu caro, porque só leio o que me agrada e só quando estou com apetite. Não troco uma conversa com uma macaquinha (o sexo na mulher corrige a banalidade, no homem agrava-a, diz Machado) pela melhor tragédia de Eurípides, porque por mais banal que seja a moça é sempre mais humana que um livro - e o humano quer o humano. Ler e comer, só quando há apetite; fora daí é uma insuportável corvée. Também não escrevo por obrigação. Escrevo quando os dedos comicham - ou quando o Benjamim ${ }^{40}$ me força a escrever. Neste caso é o meio de ver-me livre do Benjamim. Não tenho horas prediletas - minhas horas são as que coincidem com a disposição. Há horas em nos sentimos extraordinariamente aptos para pensar e tudo nos vem fácil e claro. Outras há em que estamos imaginosos, todo cheios de casulos a picarem, como ovo na hora de sair o pinto. Queria você tirar o pinto antes do tempo - o pinto morre. Estômago e cérebro: duas respeitabilidades. Respeitemo-las, Rangel." 41

Ao longo dos quarenta anos dessa troca epistolar, há referências aos mais variados assuntos, desde considerações sobre a vida cotidiana até reflexões de cunho filosófico, além dos tão estudados assuntos literários. Estes concernem tanto a autores e obras quanto à produção de Rangel e Lobato, no bojo do caráter testemunhal dessa correspondência.

Na hipótese pela qual os autores que aparecem mais constantemente nas cartas funcionam como eventuais "formadores" do ficcionista, pode-se assinalar, comentados, obras e estilo de romancistas como Anatole France, Gustave Flaubert, Honoré de Balzac, Alphonse Daudet, Guy de Maupassant, Rudyard Kipling, Nietzsche, Émile Zola, Camilo Castelo Branco, Machado de Assis, entre outros.

No entanto, há outros autores; raros na epistolografia de Monteiro Lobato, que parecem não haver marcado de forma decisiva a obra do escritor. Na carta de 12 de janeiro (1910), verifica-se uma lista de teatrólogos mencionados apenas de passagem no conjunto da correspondência com Godofredo Rangel:

"Não me mandes, pois, o teatro francês [...] Tenho deles em Taubaté um
metro de estante, e acodem-me os nomes de Robert de Flers e Caillavet, o
seu irmão siamês; e Tristan Bernard o Barbinegro, espirituosíssimo e
gafadíssimo; e Maurice Donnay, todo sutilezas de bordel e salão; e Alfred
Capus, consolador dos que tudo esperam da Sorte; e Rothschild, e Paul
Hervieu, e Lavedan, e Henry Cain, e o Octave Mirbeau do Nogueira, e
Henri Bataille, e o traumatizante Bernstein, e Dario Nicodemi, o amante da
faisandée Réjane; e Porto-Riche, e Tarride, e o Edmond Rostand do
Ricardo... Acho que em França há mais teatrólogos do que espectadores." ${ }_{42}$

\footnotetext{
${ }^{40}$ Benjamin Pinheiro manteve em Pindamonhangaba o jornal Minarete, de julho de 1903 a julho de 1907, no qual Lobato colaborava.

${ }^{41}$ LOBATO, Monteiro. A barca de Gleyre. Ed. cit., p. 54. Carta de São Paulo, 10/01/1904.

${ }^{42}$ IDEM, ibidem, p. 234. Carta de Areias, 12/01/1910.
} 
Ainda que muitos volumes desses autores ocupem suas estantes, o próprio Lobato os anula, fato este que de algum modo justifica a quase ausência completa do teatro na obra lobatiana.

É neste sentido a abordagem de um possível "período de formação" que Lobato tenha vivenciado como leitor e como escritor, em uma espécie de "aprendizado literário", o que permite reunir traços relativos à sua concepção de literatura e estilo e relacionar suas leituras nos anos iniciais da sua correspondência com Godofredo Rangel. Ademais, a pesquisa desenvolvida na Iniciação Científica, orientada pela Profa. Marisa Lajolo, contribuiu para que, por intermédio da epistolografia de Monteiro Lobato, fosse possível conhecer uma faceta do escritor em sua "formação", e delinear uma espécie de percurso de leituras até 1918, quando vem à luz Urupês.

A partir do levantamento realizado, foi organizada uma tabela, servindo como ponto de partida para a pesquisa atual, na qual se reuniu os autores e as obras citados por Lobato em A barca de Gleyre, como pode ser verificado no COMPLEMENTO A, nesta dissertação.

A organização cronológica da tabela associa as leituras à produção do escritor. Esse cruzamento de dados dá acesso à análise do diálogo do leitor com autores e obras que lhe valeram como mestres ou matrizes. Além disso, elaborar uma tabela com os autores e obras citadas auxilia na tarefa de investigar os indícios no acervo da Biblioteca Infantil Monteiro Lobato e no Fundo Monteiro Lobato do CEDAE. O levantamento também propõe contribuir no sentido de delinear vestígios de diálogos na ficção lobatiana, diante da impossibilidade de recuperação da biblioteca completa, hoje parcialmente conservada nos acervos citados, visando uma reconstituição virtual hipotética.

Por quais autores Monteiro Lobato se interessou? De que forma ele discute literatura com Rangel? Quais referências literárias encontramos nas cartas? Quais diálogos podem se estabelecer entre leitura e escritura? O que restou da biblioteca lobatiana?

Norteada por pressupostos relacionados à Epistolografia e à Crítica Genética, esta dissertação objetiva recuperar parte das referências de leituras feitas pelo escritor, por meio das diversas citações a autores e obras deixadas n’ A barca de Gleyre. Além disso, tenciona recolher informações acerca dos títulos que estiveram nas estantes da biblioteca lobatiana e levantar quais ainda permanecem no acervo do escritor na Biblioteca Infantil e na Unicamp. Adiantamos que, ao final do trabalho, discutiremos aspectos do livro História do mundo para 
as crianças, adaptação da obra norte-americana A Child's History of the World, de Virgil Mores Hillyer. O exame do exemplar presente no acervo da Biblioteca Infantil Monteiro Lobato, com notas da leitura de Lobato, recupera elementos da gênese da adaptação feita por ele.

Diante de tais objetivos, esta pesquisa também desvela possíveis fontes da criação literária, no diálogo estabelecido entre leitura e escritura. É nesse sentido que recuperamos a afirmação de Telê Ancona Lopez:

"Nas influências reconhecidas, nas leituras declaradas, na presença de
determinadas obras na biblioteca de um escritor, nas notas autógrafas à
margem de suas leituras ou em folhas anexadas a volumes, em todas as
formas e feições de recriar, insinuam-se matrizes, instaurando-se o diálogo
que traz a interdisciplinaridade da criação. As matrizes mostram-se de forma
principal quando se ligam ao modo de formar; quando textos ou elementos
de um texto - tema, motivos, sequências, cenas, personagens, marcas do
espaço, do estilo etc - enraízam a (re)criação que se afirma com
originalidade e autonomia ao integrar outro contexto." ${ }^{43}$

A localização das referências é o ponto de partida para a compreensão do diálogo intertextual das leituras de Lobato com a sua ficção. Serão, pois, examinandos os processos de absorção e integração dos elementos alheios na criação lobatiana e na transformação das fontes operadas, concordando, com Leyla Perrone-Moisés, que:

"[...] a literatura se produz num constante diálogo de textos, por retomadas, empréstimos e trocas. A literatura nasce da literatura; cada obra nova é uma continuação, por consentimento ou contestação, das obras anteriores, dos gêneros e temas já existentes. Escrever é, pois, dialogar com a literatura anterior e com a contemporânea." ${ }^{4}$

Além disso, nas palavras da ensaísta, é preciso que se tenha em vista que "A obra literária não como um fato consumado e imóvel, mas como algo em movimento; porque ela traz inscrita em si as marcas de sua gênese, dos diálogos, absorções e transformações que presidiram o seu nascimento [...]"45.

A multiplicidade de menções a autores e obras na correspondência remetida a Rangel, (como consta no COMPLEMENTO A), permite mapear um possível panorama das leituras feitas pelo escritor. É claro que não se deve perder de vista a imagem que o remetente desenha de si próprio enquanto leitor. Porém, o confronto das referências nas cartas com as

\footnotetext{
${ }^{43}$ LOPEZ, Telê Ancona. "A biblioteca de Mário de Andrade: seara e celeiro da criação". In: ZULAR, Roberto (org.) Criação em processo: ensaios de crítica genética. São Paulo: FAPESP/Iluminuras, 2002, p. 48.

${ }^{44}$ PERRONE-MOISÉS, Leyla. "Literatura comparada, Intertexto e antropofagia". In: Flores da escrivaninha: ensaios. São Paulo: Companhia das Letras, 1990, p. 94.

${ }^{45}$ IDEM, ibidem, p. 97.
} 
obras restantes da biblioteca de Lobato aponta caminhos assim como as traduções e adaptações feitas pelo escritor.

Ao eleger A barca de Gleyre nosso corpus, contamos com 340 cartas e dois bilhetes onde buscamos indícios das leituras de Lobato, os quais pusemos em contato com a remanescência de sua biblioteca no acervo da Biblioteca Infantil Monteiro Lobato e do Fundo Monteiro Lobato no CEDAE da UNICAMP. Diante da abundância de referências, destacamos os caminhos que nos pareceram plausíveis.

Deste modo, a primeira parte da dissertação, 'Leituras e literatura n'A barca de Gleyre", concentra-se em explorar as referências literárias deixadas nas cartas trocadas com Rangel. No capítulo 1, "De encontro a ou ao encontro de? Lobato e a França", analisamos as menções à littérature française e a aspectos do posicionamento de Lobato frente aos efeitos da forte assimilação das letras francesas no Brasil. No capítulo 2, "Um Lobato de cá e um português de lá...”, enfocamos sua aproximação da literatura e da língua portuguesa. Aos poucos, os franceses deixam de interessar Lobato e a literatura portuguesa é tomada, em especial, como fonte para o estudo da língua. É assim que mergulha em Camilo Castelo Branco, seu autor mais lido na época delimitada.

O que discute o capítulo 3, "Ler ou não ler os brasileiros, eis a questão!", decorre da verificação de que o contato com a literatura brasileira foi intensificando-se na medida em que nosso escritor diminui sua dedicação aos clássicos franceses e portugueses. Até aqui, pode-se dizer que as leituras estavam principalmente relacionadas com a formação e, de certo modo, eram vistas como fonte de estudo e aprendizado. Depois, quando Lobato se projeta como autor e editor de sucesso, a correspondência passa a testemunhar novos sentidos nas relações do leitor com a literatura. Outras literaturas estrangeiras e a faceta de tradutor são focalizadas no quarto capítulo, "Um Lobato e muitas literaturas". Para ele, o trabalho de traduzir é acompanhado de intensas leituras, tendo a tradução lhe rendido os primeiros ganhos em atividades intelectuais.

Na segunda parte da dissertação, "Vestígios da biblioteca de Monteiro Lobato", no primeiro capítulo "Das cartas até a biblioteca do escritor" estudamos os títulos que pertenceram a Lobato e hoje estão depositados nos acervos acima referidos. Em seguida, ainda no mesmo capítulo, encerramos a dissertação com a análise das notas de leitura no exemplar de A Child's History of the World, de Hillyer, localizado na Biblioteca Infantil, 
notas que constituem o primeiro manuscrito conhecido da adaptação História do mundo para as crianças.

Disponibilizamos um COMPLEMENTO ao final do trabalho com documentos e tabelas mencionadas ao longo da dissertação. 


\section{PARTE I}

\section{LEITURAS E LITERATURA N'A BARCA DE GLEYRE}




\section{Capítulo 1}

\section{De encontro a ou ao encontro de? Lobato e a França}

"A literatura francesa infeccionou-nos de tal maneira que é um trabalho de Hércules remover suas sedimentações. É gafeira lamelar. Temos de ir tirando aquilo casca por casca."

Monteiro Lobato ${ }^{1}$

Conto, crônica, poema, novela, biografia, memórias, romance? Quais eram as leituras de um jovem brasileiro no início do século $\mathrm{XX}$ ? O que um universitário das Ciências Jurídicas e Sociais do Largo São Francisco lia? Ora, lemos os franceses! Em 1903, essa poderia ser a resposta do jovem Monteiro Lobato.

Sabe-se que os estreitos vínculos estabelecidos entre o Brasil e a França permitiram uma tradição em que tanto a língua como a literatura francesa foram incorporadas, durante muitos anos, às sete séries da escola secundária ${ }^{2}$. Segundo Ítalo Caroni, nossos estudantes puderam se deliciar com textos de Villon, Montaigne, Corneille, Pascal, Racine, Voltaire, Flaubert e outros, da Idade Média ao século XIX ${ }^{3}$.

Leyla Perrone-Moisés, em "Galofilia e galofobia na cultura brasileira", analisa momentos do diálogo Brasil-França, considerando que nem sempre esse relacionamento foi de amor, como também enfrentou momentos de instabilidade e até mesmo rejeição.

Em se tratando de Monteiro Lobato, a citação no início deste capítulo revela apenas parte do posicionamento dele frente aos efeitos da forte assimilação das letras francesas no território tupiniquim. Como se constitui essa relação? Amor? Ódio? Amor e ódio? Nem amor, nem ódio!

\footnotetext{
${ }^{1}$ LOBATO, Monteiro. A barca de Gleyre. Ed. cit., p. 336. Carta da Fazenda, 07/12/1915.

${ }^{2} \mathrm{Na}$ atual nomenclatura, as séries correspondem atualmente aos anos $6^{\circ}$ ao $9^{\circ}$ do Ensino Fundamental II e $1^{\circ}$ ao $3^{\circ}$ do Ensino Médio.

${ }^{3}$ CARONI, Ítalo. "Francês literário ou francês instrumental?" In: ANTONIO CANDIDO, CARONI, Ítalo, LAUNAY, Michel. O francês instrumental: a experiência da Universidade de São Paulo, São Paulo: Hemus, 1977, p. 18-24.

${ }^{4}$ PERRONE-MOISÉS, Leyla. "Galofilia e galofobia na cultura brasileira". In: Vira e mexe, nacionalismo: paradoxos do nacionalismo literário. São Paulo: Companhia das Letras, 2007, p. 51.
} 


\section{As amizades literárias}

Ao focalizar as referências a leituras rastreadas em A barca de Gleyre, percebe-se até 1910 o predomínio de citações de autores e obras relacionadas ao universo da literatura em língua francesa. Nos anos seguintes, cresce o gosto por escritores portugueses e brasileiros, embora permaneçam as menções à littérature française.

Se o período 1903-1918 é considerado o mais intenso da troca epistolar entre Monteiro Lobato e Godofredo Rangel, logo, a presença francesa nas cartas deixa pistas da posição de destaque ocupada por ela na formação de Lobato escritor. É nesse sentido que a leitura da correspondência, enquanto testemunho de uma época, permite reunir aspectos do papel da cultura francesa (de modo especial, da literatura) em seu diálogo com o Brasil nos primeiros decênios do século XX.

Cabe notar que a relação com a França, registrada em $A$ barca de Gleyre, não se prende unicamente da literatura, pois verificam-se referências a personagens históricas, como Luís XVI, Robespierre, Napoleão, entre outras.

Nas cartas, destacam-se inúmeros empregos de vocábulos e expressões em francês, como qu'est ce que c'est que ça, tour du monde, épave, pince-nez, atelier, argot, flirt, grincheux, toilletes, souvenir, besogne, maillot, tout passe, etc., entremear este que ocorria também na esfera oral cotidiana da época.

Há momentos em que frases inteiras são transcritas de livros. Nesta carta de 21 de janeiro, 1907, dirigida a Godofredo Rangel, Lobato interpõe os idiomas e incorpora citação do polêmico escritor Restif de la Bretonne (1734-1806) em meio a uma discussão sobre mulheres:

"Entre centenas de criaturas apagadas e incolores, dessas que sofrem do maior dos males, pois, como diz Retif de la Bretonne, '... le plus grand mal c'est l'obscurité, c'est la vie de ces plantes mouvants qui végètent autour de vous, qui vivent et qui meurent sans que personne se soit aperçu de leur existence ${ }^{, .} .5$

\footnotetext{
${ }^{5}$ LOBATO, Monteiro. A barca de Gleyre. Ed. cit., p. 136. Carta de Areias, 21/01/1907.
} 
A carta de 22 de setembro de 1907, não só reúne críticas de Lobato como mostra o quanto ele estava intelectualmente envolvido com a produção literária francesa:

"De um ano para cá tenho acompanhado o movimento literário da França de hoje e me parece que não decai do anterior - tão nosso conhecido, com Zola, Daudet, Goncourt, Flaubert; e hoje te mando um volume do Tristan Bernard, pequena obra prima de psicologia espirituosa, com muitas semelhanças com teu estilo e alguns personagens evidentemente furtados dos teus borrões. Nascido em França, serias o próprio Tristan Bernard. Lê e julga.

"Dos autores que venho lendo e acho que posso recomendar, tenho como o mais paradoxalmente fino o requintadíssimo Marcel Prévost, nas Lettres de femmes (três volumes), Lettres à Françoise, Jardin secret, etc. Abel Hermant ironiza com muita superioridade em Les transatlantiques (americanos em Paris), em Confession d'un homme d'aujourd'hui, em La carrière (costumes da diplomacia) - são os que tenho aqui. E Anatole? Esse você sabe. Abafa tudo. Há Paul Hervieu e Henri Lavedan na comédia. Henri Bernstein é um Shakespeare up to date. La raffale, Le bercail. Todo coup de foudres. Maurice Barrès, límpido como um cristal. Léon Frapié. Pierre Weber. Na poesia graúda, Verhaeren - o homem que associou ao polvo as grandes cidades. Quando alguém pronunciar perto de você esse horrível nome, boceje esfastiado e murmure 'Cidades tentaculares' - e haverá arregalamento de olho. Nunca deixes de associar tentáculos ao nome de Verhaeren, porque desmoraliza." 6

Como frequentador do Café Guarani, à rua 15 de novembro em São Paulo, Lobato costumava conversar sobre literatura com os amigos e manter-se informado dos assuntos literários em voga. Ao que parece, com o propósito de participar a Rangel essa pluralidade de escritores, apresenta-lhe Émile Verhaeren (1855-1916) e prescreve ao amigo um comportamento diante do poeta belga de expressão francesa, prática esta tendente a formar gosto.

Essa estratégia de discussão suscita indagações: será que Monteiro Lobato lia tudo aquilo que conta em cartas ou apenas conhecia títulos e associações como esta que se nota na carta? Qual era seu conhecimento da literatura francesa? Lia algum crítico literário?

Assim como na biblioteca de Mário de Andrade (1893-1945), nas estantes lobatianas há espaço para Verhaeren, consagrado como o primeiro poeta da vida moderna. Enquanto que, para o modernista, a obra de Les villes tentaculaires precedées de Les campagnes hallucinées pode ser classificada como matriz geradora de Paulicéia desvairada (1922) ${ }^{7}$, o

\footnotetext{
${ }^{6}$ IDEM, Ibidem, p. 163-4. Carta de Areias, 22/09/1907.

${ }^{7}$ Cf. LOPEZ, Telê Ancona. A criação literária na biblioteca do escritor. Ciência e Cultura, São Paulo, v. 59, n.1, jan./mar. 2007. Disponível em: http://cienciaecultura.bvs.br/scielo.php?pid=S0009-

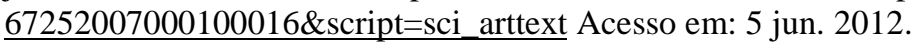


nome Verhaeren restringe-se à conversa epistolar de Lobato com Rangel em 22 de setembro, 1907.

Quando se volta para o primeiro ano da correspondência, 1903, o índice de alusões ao universo francês é extenso; localizam-se referências a Émile Zola, Voltaire, Flaubert, Edmond Rostand, Louis Veuillot, Champollion, Alphonse Lamartine, Jules Michelet, Ernest Renan e Alphonse Daudet.

Impregnado de leituras gálicas, o autor de Urupês, em maio de 1905, demonstra forte assimilação em sua escrita epistolar: "Se te queixas de trabalho em excesso, que direi eu, vítima do excesso oposto, surmenage de faineantise?";; "Você tem a besogne, o amor, um Moloch que devora tudo quanto nossas faculdades produzem, mas o teu mal está em que o teu Moloch é um Moloch literário"9 . A Lobato, como a muitos brasileiros cultos de então, parece necessário o emprego de vocábulos e expressões francesas por não achar equivalentes em sua língua-mãe, fato este que admite na continuação da carta:

"Que tanto Moloch! É que ontem estive conversando Salammbô com um velho filósofo daqui e hoje topei no Minarete com um artigo Moloch. Quer dizer que por estes dias o jongleur do meu trapézio do Brás Cubas vai ser essa palavra. Antes foi abbatteur de besogne. Que expressão nossa diz o mesmo? Sugere-me um pescoço enorme, ombros colossais, uma coragem de trabalho à Balzac ou Dumas. E tens a audácia de atirar-me à cara essa expressão tremenda a mim que sou gramínea desclorofilada e murcha..."10

A obra à qual Lobato se refere é Salammbô, publicado em 1862, romance histórico de Gustave Flaubert (1821-1880). Como não foi assinalada nas cartas a edição lida, recorreu-se ao Fundo Monteiro Lobato CEDAE/IEL/UNICAMP e ao acervo da Biblioteca Infantil Monteiro Lobato (São Paulo), onde nada foi localizado.

Moloch, nome retomado sete vezes ao longo da carta, é um deus amonita conhecido nas escrituras sagradas. Os adoradores sacrificavam-lhe recém-nascidos jogando-os na fogueira, prática ilustrada no capítulo que leva o nome dessa entidade no romance de Flaubert. Na carta, Lobato retoma metaforicamente a figura de Moloch como uma força interna que necessita ser saciada, no caso de Rangel, a própria criação literária.

Observa-se, ao longo de A barca de Gleyre, que Monteiro Lobato costumava opinar sobre escritores e textos. Embora a missiva de 13 maio de 1905 apresente referências a

\footnotetext{
${ }^{8}$ LOBATO, Monteiro. A barca de Gleyre. Ed. cit., p. 89. Carta de Taubaté, 13/05/1905.

${ }^{9}$ IDEM, ibidem, p. 90. Carta de Taubaté, 13/05/1905.

${ }^{10}$ IDEM, ibidem, p. 90. Carta de Taubaté, 13/05/1905.
} 
Flaubert, é em outras cartas trocadas com Rangel que se tem acesso às críticas lobatianas ao ficcionista:

"Eu não disse (e se disse retrato-me) que Flaubert não é artista, e sim que Flaubert me desagrada, me maça seriamente, e que me tem sido uma pura corvée a leitura de seus livros. Idiossincrasia de temperamento, vulgaridade de espírito, qualquer inferioridade minha, enfim - mas sinceridade [...]". ${ }^{11}$

Mesmo que Salammbô tenha sido assunto partilhado com Rangel, Lobato parece não gostar tanto assim do estilo flaubertiano. Em sua busca incessante da forma, Flaubert nutria a preocupação constante com a arte e a ciência; sabe-se de seu hábito de viajar e fazer anotações de cenas, imagens, impressões de sons, cores e cheiros; o estudo dos arquivos da criação revela como a sua produção literária carrega palavras, expressões, frases e imagens de cartas e relatos de viagens ${ }^{12}$. Aliás, o romance Salammbô adveio de sua visita às ruínas de Cartago.

Ainda que Lobato não aprecie os textos do autor de L'éducation sentimentale, suas considerações na carta de 2 de fevereiro, 1905, mostram certo conhecimento de aspectos estéticos da produção de Flaubert ao apontar a assimilação, por parte de Rangel, no conto "Gouache":

"O teu 'Gouache' do último Minarete (o prodigioso revisor do Benjamin ${ }^{13}$ deixou sair 'Gonache', palavra sem significação que deve estar dando dor de cabeça nos pidamonhangabanos), e teu 'Gonache' é uma pura imitação pastichada desse Flaubert que te anda estragando as tripas do estilo. Entre a maneira de Flaubert e a de Rangel a diferença é nula - o que seria ótimo para você, se você houvesse vindo ao mundo antes de Flaubert.

"Escapaste da imitação do Eça, mas sem sentir imitas o abominável Flaubert. Coisas assim, assinadas por Flaubert, seriam admiráveis - em você não passam de engenhosos ecos"14.

Se na carta de 10 de janeiro de 1904, Lobato exorta: "Sare, homem! Estás malíssimo de ingurgitamento literário. Vomite o Flaubert!"15, em 19 de agosto, 1905, verificam-se indícios de que Godofredo Rangel já não admirava tanto o rigor de Flaubert no estilo, na forma:

\footnotetext{
${ }^{11}$ IDEM, ibidem, p. 85. Carta de Taubaté, 02/02/1905.

${ }^{12}$ Cf. RIBEIRO, Lúcia Amaral de Oliveira. Artifícios e entrega ao exercício da linguagem. Um estudo sobre Flaubert. In: Congresso Internacional da Associação de Pesquisadores em Crítica Genética, X Edição, 2012. Disponível em: http://ebooks.pucrs.br/edipucrs/anais/apcg/edicao10/Lucia.Ribeiro.pdf Acesso em: 03 nov. 2012.

${ }^{13}$ Benjamin Pinheiro foi o fundador do jornal Minarete, publicação esta que circulou em Pindamonhangaba/SP de 1903 a 1907 e que tanto Monteiro Lobato quanto Godofredo Rangel colaboraram com textos.

${ }^{14}$ LOBATO, Monteiro. A barca de Gleyre. Ed. cit., p. 85. Carta de Taubaté, 02/02/1905.

${ }^{15}$ IDEM, ibidem, p. 54. Carta de São Paulo, 10/01/1904.
} 
"Gostei do teu tédio pós-flaubertiano. É prova de mais um encontro nosso. A canseira que o excessivo trabalhado do estilo dava a Flaubert penetra também o leitor. Cansaço por indução. Para mim é como se assistisse a uma ópera em teatro de vidro, onde os cenários e as paredes transparentes deixassem ver toda a maquinaria oculta. Um anjo passa voando na apoteose final e toda a beleza do voo lá se vai porque o espectador está vendo os arames de suspensão. O trabalhado de Flaubert transparece em toda a sua obra - ou é sugestão minha por saber que ele trabalhava demais as frases? Às vezes gastava todo um dia com uma delas, e esgoelá-la em todos os tons. [...] Ainda ontem vi com um rapaz daqui um horroroso relógio de mostrador transparente, com toda a engrenagem - toda a barrigada - visível. Flaubert é assim. Imagine uma moça belíssima, mas de carnes diáfanas, com as tripas, os bofes, o coração e todas essas coisas vermelhas aparecendo... $\mathrm{E}$ Flaubert ainda é, como dizes, 'secante'. O pai foi médico e os avós também. $\mathrm{O}$ filho herdou a fúria de escalpelar. Aquilo dele pegar e dissecar tipos incaracterísticos como a Bovary, Homard etc. acaba secando a gente. Eu gosto dum Tartarin, dum Besoukov, dum Lantier, dum Ega." 16

Questões estilísticas e comparações literárias frequentemente perpassam as críticas lobatianas. Para ele, o excessivo trabalho na fatura da obra dificultaria a leitura, como insiste na carta de 21 de janeiro de 1907 :

"O pior hábito teu é o Flaubert. É preciso que duvides de Flaubert - e pelas tuas cartas vejo que é o único homem no mundo de quem nem sonhas duvidar. O duvidar dos deuses e de Deus é o princípio da sabedoria. No dia em que começares a duvidar de Flaubert, cresces vinte côvados.

"A mim Flaubert me enfada: admiro-o, sim, mas como admiro a pirâmide de Quéops ou a Esfinge. [...] Flaubert me dá ideia dum pedreiro, dum carapina literário - dum sujeito que faz livros, em vez de expluí-los, exsudálos, defecá-los." 17

Se a escrita de Flaubert não apraz esse leitor, Alphonse Daudet (1840-1897) marca prazerosamente a juventude de Lobato e de seus companheiros do Minarete. Inspirado por aventuras em uma viagem à Argélia, Daudet escrevera para o jornal francês Le Figaro, em 1863, "Chapatin, le tueur de lions", narrativa que, em 1872, deu origem a Tartarin de Tarascon, Tartarin sur les Alpes (1885) e Port-Tarascon (1890).

As aventuras de Tartarin tornaram-se de tal modo presentes no cotidiano de Lobato e de seu círculo de amigos como A barca de Gleyre as espelha em referências e até mesmo em brincadeiras envolvendo trechos da obra. O Hino do Minarete, composto por Godofredo Rangel, remete ao grito de guerra dos tarasconeses de Port-Tarascon:

\footnotetext{
${ }^{16}$ IDEM, ibidem, p. 95. Carta de Taubaté, 19/08/1905.

${ }^{17}$ IDEM, ibidem, p. 139-40. Carta de Areias, 21/01/1907.
} 


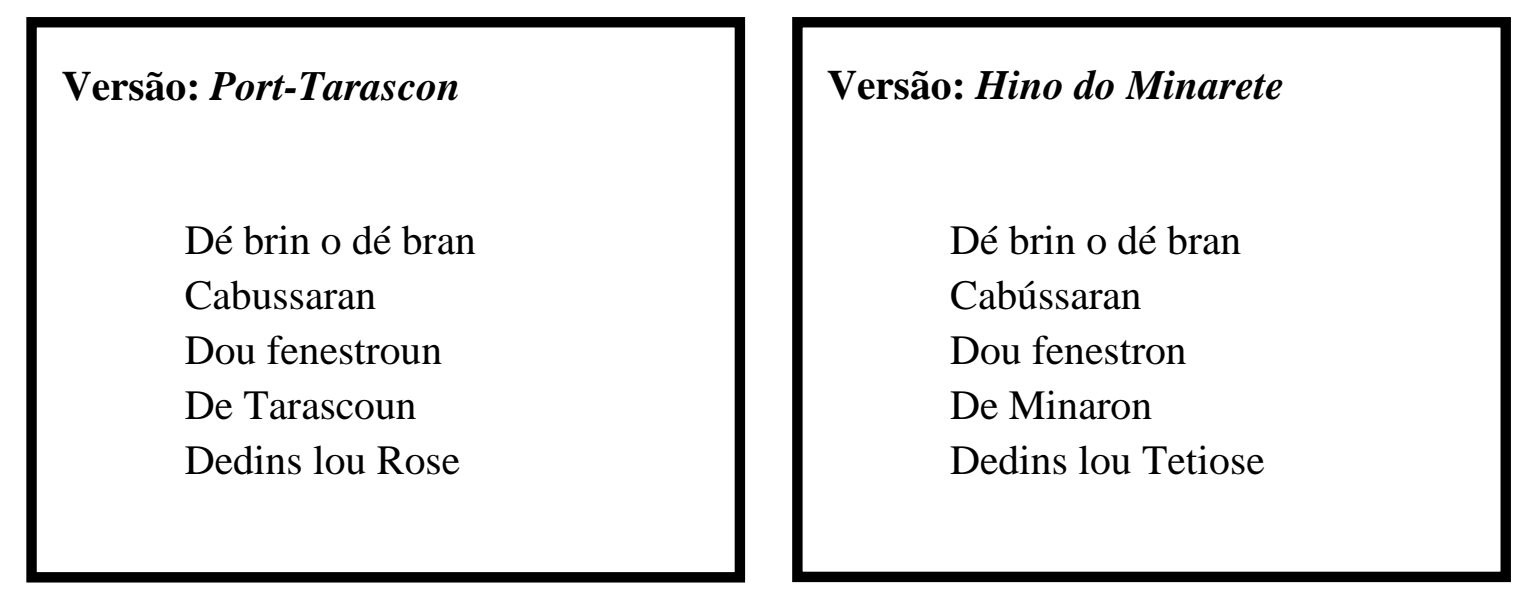

Em nota de rodapé n'A barca de Gleyre, Lobato conta que, no Minarete, os moradores recebiam os visitantes no portão cantando o hino do local e quem estava na casa aparecia à janela, saudando o visitante com o "Vé!" dos tarasconeses. Além disso, confessa que todos andavam tão imbuídos do Tartarin que se faziam personagens da história. Ricardo era o herói que deu nome a narrativa. Rangel, Bezuquet; Cândido Negreiros, Bompard; Artur Ramos, o espingardeiro Costecalde e Lobato, Pascalon, o Engraçado ${ }^{18}$.

Impregnado de Daudet, Lobato, em certas cartas, toma emprestados elementos do romance Tartarin de Tarascon. O bilhete que abre a seleção da correspondência n'A barca de Gleyre inicia-se com a saudação “Té, muezins!” e termina com “Té, Bezuquet! Vé, Tartarin!”. E uma carta de $1903^{19}$ chega mesmo a tratar o destinatário de Bezuquet.

Outros títulos de Alphonse Daudet são referidos ao longo d'A barca de Gleyre: Le petit chose, Robert Helmont, Jack, Le nabab e Sapho.

O autor de Tartarin de Tarascon perdura na lembrança de Lobato, como se vê na carta de 30 de julho de 1918:

"Há dias fui com Oswald [de Andrade] em procura do velho Minarete - pela primeira vez desde aquele nosso tempo. [...] Espiei do portão aquele 'Paradou' da entrada, aquela cercadura de canteiros maltratados que nem poda conheciam, e minha sensação foi a de coisas idas - deliciosamente idas - paisagenzinhas do Tartarin de Tarascon e do Robert Helmont..."20

Para Monteiro Lobato, Daudet é um dos amigos da época do Cenáculo, um companheiro de boas horas. A consciência do laço de amizade com as leituras mostra-se na carta de 9 de agosto, 1907:

\footnotetext{
${ }^{18}$ IDEM, ibidem, p. 35, nota da edição.

${ }^{19}$ IDEM, ibidem, p. 44. Carta de São Paulo, 1903 (sem data completa).

${ }^{20}$ IDEM, ibidem, p. 422. Carta de São Paulo, 30/07/1918.
} 
"O que achas dos autores com os quais travamos conhecimento é o que se dá
com as amizades pessoais. Quando topamos um amigo novo e com ele nos
abrimos, não abrimos coisa nenhuma - tudo é reserva e vaga hostilidade. Só
depois, quando o convívio desfaz esse velho sentimento do hospes hostis, é
que começamos a conhecer o prazer da amizade. Por que tanto nos
encantamos com Daudet? Porque é o nosso amigo literário mais velho - pré-
cenacular ainda." ${ }^{21}$

Dentre os ficcionistas franceses, Daudet ladeia Émile Zola na leitura de Lobato; é citado em 1903 e ao longo da correspondência, tem referidos os títulos Germinal, L'assommoir, La joie de vivre, Le rêve e Le docteur Pascal da série Les Rougon-Macquart, assim como Travail e Mes Heines.

Ensaiando como crítico, Monteiro Lobato discute o movimento naturalista na carta de 20 de janeiro de 1904:

"Acho Graça Aranha novo. Abre caminho para o artista-filósofo, o artista de cultura moderna que há de substituir os meros naturalistas descritivistas à Zola (mas sem o gênio esmagador de Zola). Zola me lembra o martelo-pilão das fábricas de ferro; os seus imitadores são martelos de quebrar coquinhos. O naturalismo foi uma reação violenta contra os exageros do romantismo. Mas o naturalismo passou da conta e por sua vez está provocando reações. O naturalismo acabou em fotografia colorida. $\mathrm{O}$ adjetivo de que o Macuco mais gosta deve ser o 'nítido', e não há cretino que ao dar opinião sobre qualquer pintura (a Gioconda ou um Corot) não venha com o clássico: 'Como está nítida'. Pois foi isso. O naturalismo morreu no nítido fotográfico. $" 22$

Enquanto Graça Aranha agrada Lobato com o romance sócio filosófico Canaã, o excesso de minúcias no campo da descrição e o ideal de que a escrita deva se alimentar de cores verdadeiras, assim como a fotografia, o afastam do naturalismo de Zola.

O escritor admite, contudo, o papel das leituras zolaianas na sua formação: "Um defeito meu, teu, nosso: damos espaço demais ao cenário, com prejuízo das figuras [...] Nós nos perdemos nas mignardises da paisagem, a copiar até as perninhas dos carrapatos - vício que vem do tempo em que o naturalismo zolaiesco nos seduziu." 23 .

É do conhecimento geral que, assim como Flaubert, Zola costumava aprofundar-se no estudo do meio, munindo-se de anotações e materiais d'après nature para os utilizar em seus romances. Para Lobato, não basta reproduzir a sociedade nas páginas do livro; um grande escritor deve expressar sua individualidade artística e não simplesmente transpor

\footnotetext{
${ }^{21}$ IDEM, ibidem, p. 160-1. Carta de São Paulo, 09/08/1907.

${ }^{22}$ IDEM, ibidem, p. 57. Carta de Taubaté, 20/01/1904.

${ }^{23}$ IDEM, ibidem, p. 301. Carta da Fazenda, 30/01/1915.
} 
fotograficamente a realidade que o circunda. É neste sentido que, em 23 de outubro de 1915, reaparecem suas críticas ao naturalismo:

"Tomei-me de tal engulho pelo naturalismo formalístico, impessoal pedaços da natureza vistos através dum molde -, que o considero máquina de fabricar linguiça. Entram pela boca Zola, Aluísio e tutti quanti, sobraçando o assunto; dá-se à manivela e sai do outro lado sempre a mesma linguiça, na forma e no comprimento, apenas com leves diferenças no tempero interno." 24

O Monteiro Lobato de 1917, pouco antes publicar Urupês, está construindo sua identidade no universo literário. Assim, quer mostrar a Rangel o desvinculamento dos ideais que tanto os atraíram na mocidade ${ }^{25}$ :

"Nós, Rangel, nós do Minarete, viciados pelo senhor Émile Zola até no modo de pegar a caneta, pervertemos com a maneira de Zola - ótima e certa nele, porque era dele, mas péssima em nós porque nos sufocava o surto da nossa maneira [...] E hoje que o 'naturalismo' zolaico passou, ainda andamos patinhando por lá, como gente de anquinhas em estação de vestidos colantes" ${ }^{\prime 26}$.

Enquanto o estilo literário de Zola e de Flaubert não agradam nosso escritor, há um francês que o encanta, Honoré de Balzac (1799-1850):

"Há tempos que ando para te dizer duma leitura que me pôs esbarrondado. Lys dans la vallée, de Balzac, foi romance que sempre me afugentou por causa do sentimentalismo do título, mas agora, em falta de título de maior sugestão, fui-me a ele - e dele saí como quem sai dum mundo novo. Conheces Balzac? Se não leste o Lys posso afirmar que não, porque é ali que Balzac assume as proporções desmarcadas dum Shakespeare do romance. A princípio me soou entediante e falsa a sua maneira de tratar o assunto; mas breve, reconsiderando e mudando o sistema de ler - lendo-o como o fanático lê uma encíclica e não como nós lemos um romance, a voar de ideia em ideia dentro do carro do estilo - lendo e pensando, lendo devagar, lendo palavra por palavra, frase por frase, cheguei a ponto de lê-lo dum modo novo: ler admirando, ler em êxtase, ler com espanto, ler bebendo as frases com o terror sagrado da beata que ingere a hóstia. Porque Balzac - só agora o percebi - é o Grande Gênio da literatura moderna. Compreendes? Balzac é o gênio da alma moderna, como Shakespeare foi o gênio da alma antiga. Penetrar, como Balzac o fez, no fundo do pensamento moderno, e pôr a nu todas as almas, quem mais que Balzac o fez? Meu entusiasmo é tanto que só tenho um conselho a dar-te: lê o Lírio do vale e depois varre da tua cabeça o alfabeto, para que nunca mais nenhum livro venha profanar essa leitura suprema e última. Lê o Lírio,

\footnotetext{
${ }^{24}$ IDEM, ibidem, p.333. Carta da Fazenda, 23/10/1915.

${ }^{25}$ Embora não seja o foco de nosso estudo, vale lembrar que no campo da crítica de arte, a influência de Zola nos ideais artísticos de Lobato pode ser percebida. Tadeu Chiarelli aproxima os dois autores por possuírem, entre outras características, a mesma concepção de arte. Cf. CHIARELLI, Tadeu. "Lobato antes de Lobato". Um jeca nos vernissages. São Paulo: EDUSP, 1995, p. 107- 141.

${ }^{26}$ LOBATO, Monteiro. A barca de Gleyre. Ed. cit., p. 407-8. Carta de Caçapava, 03/10/1917.
} 
Rangel, e morre. Lê o Lírio e suicida-te, Rangel. Se não o tens aí, posso mandar-te o meu exemplar - e junto o revólver." 27

Conhecido por formar em sua obra um painel da sociedade oitocentista, Balzac é considerado o fundador do realismo na literatura moderna. Publicado em 1835, Le lys dans la vallée integra uma das oitenta e oito histórias do conjunto La comédie humaine. Ao que parece, esse foi o primeiro romance do ficcionista francês lido por Lobato. Observa-se o didatismo do missivista no intuito de suscitar a leitura do amigo. Além disso, o entusiasmo do leitor estende-se a outros títulos que lhe integram o repertório:

"Ontem perdi o sono e conclui a leitura do Cousine Bette. Rangel, Rangel! Balzac me assombra. É gênio dos absolutos. Lembro-me duma imagem de Zola, comparando a obra de Balzac a um colossal edifício inacabado - tijolos nus, andaimes, só o arcabouço externo. Não é nada disso. Não tem nada de inacabado - mas Balzac não é homem que desça a truques, remates, ornatos secundários. Pinta a largas espatuladas. Diz o essencial, cria blocos apenas, formidáveis blocos, mas não alisa a pedra, não usa lixas, não lhes enfraquece a grandeza. Que tipos! Que prodígios! Que coerência! Que fertilidade! Que mina! Que celeiro de ideias e imagens! Que multidão de gente viva e estua dentro de seus romances! Como perto dele é pálido e artificial Zola, com sua arte mecânica, sua lógica invariável, seu romantismo despido das belezas heroicas do romantismo! Balzac nem em capítulos divide a narrativa. Aquilo rompe e rasga, e vai numa catadupa tumultuosa, numa avalanche, até o fim. Quelle puissance! Já li César Birotteau e a Cousine e afundo-me agora em toda a sua obra, como num mar. Já não dispenso todo Balzac!"28

Uma característica da crítica de Lobato é a comparação. Assim, em meio aos elogios à escrita balzaquiana, reaparece a opinião quanto ao estilo de Zola. Pode-se apontar, na carta de 15 de maio de 1914, a recorrência desse procedimento: "Contes drolatiques? Sim, conheço. Balzac é grande em todos os gêneros - e igualmente o contrário de Flaubert em todos.",29

Nota-se que o interesse de Lobato pelos textos de Balzac foi aumentando. Se antes o título Le lys dans la vallée o afastava pelo sentimentalismo, após ler este romance, na carta de 15 de setembro de 1908, admite o mergulho no autor de La comédie humaine. Cabe lembrar que, neste caso, as cartas são os únicos testemunhos de que dispomos dessa leitura, uma vez que tanto no Fundo Monteiro Lobato quanto na Biblioteca Infantil em São Paulo não foram identificados exemplares de obras de Balzac que tenham integrado o acervo lobatiano.

\footnotetext{
${ }^{27}$ IDEM, ibidem, p. 178-9. Carta de 1908 (sem local e data completa).

${ }^{28}$ IDEM, ibidem, p. 182. Carta de Areias, 15/09/1908.

${ }^{29}$ IDEM, ibidem, p. 284-5. Carta da Fazenda, 15/05/1914.
} 
Diferente é o que ocorre com Anatole France (1844-1924). Estão depositados no acervo do CEDAE, na Unicamp, dois títulos dele que pertenceram a Monteiro Lobato: La révolte des anges ( $1^{\mathrm{a}}$ ed.) e Les contes de Jacques Tournebroche (sem indicação da edição, apenas o ano 1909), sendo que este último conta com a dedicatória do cunhado: "Ao Lobato, lembrança affectuosa do Heitor de Moraes. Santos. 6 - julho - 1913". ${ }^{0}$ Já na Biblioteca Infantil Monteiro Lobato, localizam-se os exemplares de Histoire comique e Le crime de Sylvestre Bonnard, todos em primeira edição. ${ }^{31}$

Afora a recolha de vestígios que auxiliam na tarefa de reconstituir a biblioteca dispersa de Monteiro Lobato, há trechos em A barca de Gleyre que convalidam o apreço por Anatole France. Na carta de janeiro de 1907, Lobato recomenda a Rangel, em tom humorístico, a leitura de Anatole, a fim de que ele se cure da "flaubertite crônica"! É claro que a brincadeira marca o próprio estilo lobatiano, assim como o discurso pedagógico:

\begin{abstract}
"Por que não afundas em Anatole, Rangel? Sabe que isso já está me revoltando - essa demora em entrares no bom porto? Para começo da catequese prescrevo Crainquebille, Putois, Histoire comique (onde o cômico é um ator; aqui em Areias os velhos usam ainda usam a palavra 'cômico' por 'ator'), L'orme du mail, La rôtisserie de la reine Pédauque e o Abbé Coignard - a filosofia mais alta que o homem produziu até hoje - um encanto de diálogos. Com estas leituras você sarará da flaubertite crônica esta gota militar adquirida no Minarete." 32
\end{abstract}

Lobato entende as leituras como parte da formação de ambos os escritores, logo, considera importante conhecer diferentes padrões estético-estilísticos. Por essa razão, não esconde o aborrecimento diante daquilo que lhe parece teimosia em Rangel:

"Temos velhas contas a justar. No bilhete em que declinas do cargo de cronista da Ascensão, há isto: 'Não pude ler o Sur la pierre blanche!'.

"Não pôde? Impossibilidade material, como olho furado? Proibição da polícia? Ou não pudeste ler por inferioridade da obra, ilegibilidade do Anatole France?

\footnotetext{
30 FRANCE, Anatole. La révolte des anges. $1^{\mathrm{a} e d .}$ Paris: Calmann-Levy, 1914. Localização no acervo CEDAE/IEL/UNICAMP: código MLb 800048.

IDEM. Les contes de Jacques Tournebroche, Paris: Calmann-Levy, 1909. Localização no acervo CEDAE/IEL/UNICAMP: código MLb 800012.

31 IDEM. Histoire comique. $1^{\text {a }}$ ed. Paris: Calmann-Levy, 1903. Localização no Acervo Monteiro Lobato, Biblioteca Infantil Monteiro Lobato: CDD 843.7.

IDEM. Le crime de Sylvestre Bonnard. 1 ${ }^{\mathrm{a}} \mathrm{ed}$. Paris: Calmann-Levy, 1881. Localização no Acervo Monteiro Lobato, Biblioteca Infantil Monteiro Lobato: CDD 843.7.

${ }^{32}$ LOBATO, Monteiro. A barca de Gleyre. Ed. cit., p. 140. Carta de Areias, 21/01/1907.
} 
"Não podendo tomar o 'não pude' no primeiro caso, tomei-o no segundo - e sinceramente desejei que Hércules ressuscitasse para fazer em teu cérebro o que fez nas cavalariças de Áugias ${ }^{33}$.

"O pobre Anatole nasce com fortes aptidões filosóficas e estéticas; educase laboriosamente durante cinquenta anos de vida europeia; afinal, apura, lapida as qualidades ingênitas de pensador e artista de expressão; consegue atingir a meta suprema - vários Everests ainda não atingidos, entre eles o de 'associar às verdades extensas da Ciência as verdades profundas da Poesia'; escreve o Le lys rouge, onde bate Dante e Petrarca na descrição do maior amor que jamais existiu; cria um gênero em que ele ainda está só, uma arte nova - a de engastar raios de ironia na gema da forma; eleva o Paradoxo à estratosfera, chega a desvendar o futuro - e ensina à França o Humor. E quando esse homem alcança o zênite e produz Sur la pierre blanche, onde, na mais cristalina das linguagens, diz todas as altas ideias que embaraçam as pernas dos Sílvios Romeros - diz ideias que são como o sol de certas manhãs de maio - tu, Rangel, tu, pulgão verde da roseira literária, tu, Silvério do Reis, tu, queijo de Minas, dizes, com onze letras: 'não pude lêlo!...". 34

Na juventude, Lobato recomendara ao amigo o autor de Le lys rouge; sete anos antes de falecer, revestido de melancolia, confessa que a leitura o acompanhara até na prisão, sob o Estado Novo:

"Mas o nosso tédio, Rangel, chama-se 'velhice'. Somos uma porcaria. Somos uns cacos de pote. Nada mais nos sabe ao paladar, porque já perdemos o paladar. Você relê os velhos ídolos da mocidade e desaponta-se. Eu não releio os meus para evitar o desapontamento. Camilo, Anatole... Levei vários Anatoles para a prisão e pouco li. Já me não sabiam como antes. A beleza que encontramos nas coisas e nas gentes não está nelas - está em nós - e a idade vai apagando." 35

Com apenas o exemplar da primeira edição de Promenades dans Rome na Biblioteca Monteiro Lobato ${ }^{36}$, outra referência de Monteiro Lobato é Stendhal (1783-1842), citado em sete diferentes cartas de 1904 a 1917. A avaliação do leitor enaltece a construção do enredo das obras e demonstra sua sensibilidade crítica quanto ao texto literário:

"Se gosto de Stendhal? Imenso. Amigo velho na história da pintura, nas viagens, nas 'promenades' em Roma, no Le rouge et le noir (um assombro), na Chartreuse de Parme. A descrição que Stendhal faz da batalha de Waterloo é a maior das maravilhas. O herói não viu nada, só viu a si mesmo

\footnotetext{
${ }^{33}$ Nesse trecho, Lobato faz referência à mitologia greco-romana, mais especificamente a um dos doze trabalhos de Hércules: limpar as cavalariças de Áugias.

Áugias, rei da Élida, tinha grandes rebanhos de cavalos (ou gado, conforme a versão), mas não cuidava de seus estábulos, que acumularam uma colossal quantidade de estrume ao longo dos anos e exalava um mau cheiro tão intenso não permitindo a aproximação de ninguém. Hércules conseguiu alterar a água dos rios Alfeu e Peneu na direção dos estábulos e com a forte correnteza limpou todo o estrume acumulado.

${ }^{34}$ LOBATO, Monteiro. A barca de Gleyre. Ed. cit., p. 181. Carta de Areias, 15/09/1908.

${ }^{35}$ IDEM, ibidem, p. 547. Carta de São Paulo, 17/09/1941.

${ }^{36}$ STENDHAL. Promenades dans Rome. $1^{\mathrm{a} e d}$. Paris: Calmann-Levy, [s/d]. Localização no Acervo Monteiro Lobato, Biblioteca Infantil Monteiro Lobato: CDD 843.7.
} 
e aos companheiros mais próximos, e as cercas que andou pulando na fuga. Mais tarde é que veio a saber que aquilo fora a famosa batalha de Waterloo. No Le rouge et le noir o vermelho é o espírito napoleônico e o preto é o padre - a Reação. Stendhal tem relâmpagos; é sempre original, quase sempre sincero e poucas vezes atraente (à moda dos 'fáceis'). Gênio". ${ }^{37}$

Guy de Maupassant (1850-1893) poderia ser apenas mais um dos autores franceses registrados em A barca de Gleyre. Entretanto, a predileção pelo contista normando é tamanha que, segundo o biógrafo Edgard Cavalheiro, Lobato leu a obra completa, assim como a de Stendhal e Kipling. Se por um lado nosso jovem leitor não nutria apreço por Flaubert, é curioso notar a admiração por Maupassant, considerado discípulo do autor de Salammb $\hat{o}^{38}$.

Nas cartas, são citados os títulos Mademoiselle Fifi, Boule de suif, Clair de lune, Une vie, Miss Harriet, Bel Ami, Toine, Mont-Oriol, Pierre et Jean, Sur l'eau, La main gauche e Notre coeur. Consta do Fundo Monteiro Lobato Toine e do acervo da biblioteca do escritor, em São Paulo, os exemplares de Le horla e Sur l'eau, os três títulos sem indicação da edição ${ }^{39}$.

Ao lado do inglês Rudyard Kipling, Maupassant figura como referencial na formação do contista brasileiro. A missiva de 27 de junho de 1909 registra algumas perspectivas que Lobato almeja enquanto escritor, especificamente quanto à escolha do gênero:

"Sou partidário do conto, que é como o soneto na poesia. Mas quero
contos como os de Maupassant ou Kipling, contos concentrados em que haja
drama ou que deixem entrever dramas. Contos com perspectivas. Contos que
façam o leitor interromper a leitura e olhar para uma mosca invisível, com
olhos grandes, parados. Contos-estopins, deflagradores das coisas, das
ideias, das imagens, dos desejos, de tudo quanto exista informe e sem
expressão dentro do leitor. E conto que ele possa resumir e contar a um
amigo - e que interesse a esse amigo."

Na discussão sobre o modo ideal de escrever contos, Lobato atribui ao texto literário a necessidade de atingir o leitor e despertar-lhe algo, preocupação esta que mostra parte de seu posicionamento frente ao papel social ativo que o escritor deve desempenhar.

\footnotetext{
${ }^{37}$ LOBATO, Monteiro. A barca de Gleyre. Ed. cit., p. 58. Carta de Taubaté, 20/01/1904.

${ }^{38}$ A amizade dos dois escritores, a relação mestre e discípulo e o viés pedagógico das cartas são analisados no artigo "De Flaubert para Maupassant", de Brigitte Monique Hervot. Cf. http://seer.fclar.unesp.br/lettres/article/view/5310 Disponível em: 05 mar. 2012.

39 MAUPASSANT, Guy de. Toine. [S.l.] Mauppon, [s/d]. Localização no acervo CEDAE/IEL/UNICAMP: código MLb 8 00056;

IDEM. Le horla. [S.1] Société d'Éditions littéraires et artistiques, [s/d]. Localização no Acervo Monteiro Lobato, Biblioteca Infantil Monteiro Lobato: CDD 843.8;

IDEM. Sur l'eau. [S.1] Société d'Éditions littéraires et artistiques, [s/d]. Localização no Acervo Monteiro Lobato, Biblioteca Infantil Monteiro Lobato: CDD 843.8.

${ }^{40}$ LOBATO, Monteiro. A barca de Gleyre. Ed. cit., p. 198. Carta de Areias, 27/06/1909.
} 
É interessante notar o amadurecimento do contista. Na carta de 31 de julho de 1907, sugere ao amigo Rangel que se dedique ao gênero como meio de se aprimorar na literatura:

"No teu caso eu me dedicaria exclusivamente ao conto e me ia aperfeiçoando sempre; e muito naturalmente viria mais tarde o romance, sem forçar o temperamento - como veio ao Maupassant e ao Eça. O romance é um conto de trezentas páginas e mais engalhado - e só ergue cem quilos de peso quem durante anos se treinou em suspender halteres de dez.",41

Dois anos depois, aprofunda essa questão:

"Toda gente considera o conto um gênero leve - e tomam o leve como sinônimo de fácil. Mas note que em todas as literaturas só emerge do conto um Maupassant para dez romancistas. Mesmo assim, achas que é possível meter Maupassant na plana de Balzac, Dostoievsky e Tolstoi? Não creio. É mister fazer bom e grande e o contista, embora alcance o bom, não pode chegar ao grande. É ourivesaria, não arquitetura." ${ }^{42}$

Lobato não deixa de considerar o conto gênero menor que o romance, até mesmo pela comparação que faz entre Maupassant e outros escritores de renome. Contudo, na carta de 23 de outubro, 1909, admite que o trabalho do contista é grande e minucioso no que concerne a escritura.

Publicado em Urupês, "Meu conto de Maupassant" já indica pelo título o diálogo com o ficcionista francês. No início do texto, Lobato justifica-se:

“_ ${ }^{43}$ Anda a vida cheia de contos de Maupassant; infelizmente há pouquíssimos Guys...'

“- 'Por que Maupassant e não Kipling, por exemplo?’

“- 'Porque a vida é amor e morte, e a arte de Maupassant é nove em dez um enquadramento engenhoso do amor e da morte. Mudam-se os cenários, variam os atores, mas a substância persiste - o amor, sob a única face impressionante, a que culmina numa posse violenta de fauno incendido de luxúria, e a morte, o estertor da vida em transe, o quinto ato, o epílogo fisiológico. A morte e o amor, meu caro, são os dois únicos momentos em que a jogralice da vida arranca a máscara e freme num delírio trágico'."44

Aponta-se de imediato a opção por Maupassant na escolha temática; porém, há outros empregos que manifestam o tributo prestado ao escritor, entre os quais Ana Luiza Reis Bedê destaca: o recurso de verossimilhança (narrador em primeira pessoa que relata uma conversa ouvida), o início da narrativa com um veículo em movimento (o trem), a omissão dos verbos de declaração nos discursos diretos, o efeito final (o cenário de início reaparece e a última

\footnotetext{
${ }^{41}$ IDEM, ibidem, p. 158. Carta de Areias, 31/07/1907.

${ }^{42}$ IDEM, Ibidem, p. 228. Carta de Areias, 23/10/1909.

${ }^{43}$ A utilização das aspas ocorre por conta do trecho ser um diálogo reproduzido deste modo no conto de Lobato.

${ }^{44}$ LOBATO, Monteiro. Urupês. Edição coordenada por Arlete Alonso. São Paulo: Globo, 2007, p.83.
} 
frase em geral é a fala de alguma personagem que demonstra sua surpresa, indignação ou ceticismo sobre o que foi dito) ${ }^{45}$. Ademais, a dissertação de Ana Luiza Reis Bedê contribui na indicação de diálogos entre a orientação estilística adotada por Maupassant e os elementos dos quais Lobato se apropria, destacando: "o desprezo pela linguagem preciosa e rebuscada em prol da simplicidade; o poder de evocação das palavras, a valorização do texto enxuto, ou seja, dizer o máximo com o mínimo de recursos e a habilidade em sugerir." ${ }^{4}$.

Há ainda inúmeras referências a escritores franceses em A barca de Gleyre. Poetas, ficcionistas, teatrólogos, ensaístas... a lista é extensa e variada: Adrien Delpech, Alexandre Dumas, Alfred Capus, Allan Kardec, Alphonse Karr, André Theuriet, Auguste Comte, Barbey d'Aurevilly, Bernard Le Bovier de Fontenelle, Blaise Pascal, Bossuet, Buffon, Caillavet, Chamfort, Charles Baudelaire, Charles Perrault, Edmond de Goncourt, Eliphas Levi, Emile Faguet, Émile Littré, Emilio Sevene, François Rabelais, François-René de Chateaubriand, George Sand, Georges de Porto-Riche, Georges Ohnet, Gérard Nerval, Gobineau, Gustave Aimard, Gustave Le Bon, Henri Lavedan, Henry Berstein, Joris-Karl Huysmans, Jean-Jacques Rousseau, Jules de Goncourt, Júlio Verne, La Bruyère, La Fontaine, Lecomte de Lisle, Léon Frapié, Madame de Staël, Marcel Prévost, Marquês de Sade, Maurice Barrès, Maurice Charles Donnay, Maurice Maerterlinck, Molière, Octave Mirbeau, Paul Bourget, Paul de Saint-Victor, Paul Hervieu, Paul Koch, Paul Scarron, Paul Verlaine, Pierre Loti, Robert de Flers, Theóphile de Banville, Theóphile Gautier, Tristan Bernard, Victor Hugo, Volney e Xavier de Maistre.

Estudar cada um destes escritores na relação que tem com a formação de Monteiro Lobato e sua produção literária exigiria uma série de análises às quais o presente trabalho não se estenderá ${ }^{47}$. A escolha de abordagem foi norteada pelos nomes que mais se destacaram na correspondência com Godofredo Rangel.

\footnotetext{
${ }^{45}$ BEDÊ, Ana Luiza Reis. Monteiro Lobato e a presença francesa em A barca de Gleyre. Dissertação de mestrado (orientação: Gilberto Passos). São Paulo: Faculdade de Filosofia, Letras e Ciências Humanas, Universidade de São Paulo, 2004. p. 131-154 .

${ }^{46}$ IDEM, ibidem, p. 142.

${ }^{47}$ Ana Luiza Reis Bedê detém-se em diferentes aspectos da relação de Lobato com a França, inclusive em algumas das referências deixadas nos próprios contos lobatianos, entre eles, "Pollice verso", "A vida em Oblivion" e "A facada imortal", respectivamente encontrados nos livros Urupês, Cidades mortas e Negrinha. BEDÊ, Ana Luiza Reis. "O 'prisma francês' em Lobato". In: Monteiro Lobato e a presença francesa em A barca de Gleyre. Ed. cit., p. 57-64.
} 


\title{
Outras relações por intermédio da literatura francesa
}

\begin{abstract}
"Dum banho em Nietzsche saímos lavados de todas as cracas vindas do mundo exterior e que nos desnaturam a individualidade [...] de Nietzsche saímos tremendamente nós mesmos. O meio de segui-lo é seguir-nos. 'Queres seguir-me? Segue-te!' Quem já disse coisa maior? Nietzsche é potassa cáustica. Tira todas as gafeiras.

"E que estilo, Rangel! Aprendi nele mais que em todos os nossos franceses. É o estilo cabrito, que pula em vez de caminhar. O estilo de Flaubert é estilo tatorana: vai indo até o fim. O de Nietzsche nunca se arrasta, voa de pulo em pulo - e chispa relâmpagos, e chia, urra, insulta. É a mais prodigiosa irregularidade artística. Quando leio Nietzsche sinto ódio contra Flaubert o Impecável. Nietzsche é o Grande Pecador."
\end{abstract}

Monteiro Lobato $^{48}$

Nos primeiros anos do século passado, a obra de Nietzsche começou a difundir-se no Brasil e ficou tão conhecida que se tornou moda literária. O acesso aos textos foi possibilitado pelas traduções francesas que circulavam no país, como se percebe na carta de 24 agosto de 1904: "Rangel: há muito que quero insistir em Nietzsche, e dele te mando um volume que lerás e devolverás, e então mandarei outro. Não há Nietzsche nas livrarias desta Zululândia. Estes me vieram de França." 49

As cartas testemunham essa mediação francesa, sobretudo nas citações:

“[...] Escreve em tua porta isto da Gaya scienza de Nietzsche:

VADEMECUM - VADETECUM

Mon allure et mon langage t'attirent,

Tu viens sur mes pas, tu veux me suivre?

Souis-toi toi même fidèlement

Et tu me suivras, moi! Tout doux! Tout doux!",50

Antonio Candido destaca a função mediadora da França quando afirma que esse país não se limitou a transmitir a própria cultura, mas ajudou a propagar outras por intermédio do idioma. É o caso das versões em francês que tornaram acessíveis poetas, romancistas e filósofos, nomes como, Goethe, Byron ou Hegel, e difundiram o romance russo a partir de

\footnotetext{
${ }^{48}$ LOBATO, Monteiro. A barca de Gleyre. Ed. cit., p. 66-7. Carta de São Paulo, 24/08/1904.

${ }^{49}$ IDEM, ibidem, p. 66. Carta de São Paulo, 24/08/1904.

${ }^{50}$ IDEM, ibidem, p. 62. Carta de São Paulo, 02/06/1904.
} 
$1880^{51}$. Observa-se que o mesmo ocorre com os textos de Nietzsche, informação dada pelo próprio Lobato: “[...] Chegou-me o Nietzsche em dez preciosas brochuras amarelas, tradução de Henri Albert." ${ }^{52}$

Há ainda outros autores lidos em traduções francesas. Um exemplo está em Homero, lembrado na carta de 3 de fevereiro de 1908: "Sabe de alguma tradução de Homero em português? Leio na de Lecomte". ${ }^{33}$ Isto é, na versão assinada pelo poeta francês Lecomte de Lisle (1818-1894), tradutor de Homero e Ésquilo.

Sem perder de vista as consequências dessa mediação, inclusive as inerentes lacunas vindas da interpretação e da tradução, as versões francesas também permitiram a criação de traduções em língua portuguesa. Para ilustrar essa complexa rede de difusão cultural, pode-se tomar as traduções de $O$ anticristo e $O$ crepúsculo dos ídolos, de Nietzsche, feitas por Lobato a partir da versão francesa de Henri Albert, sendo que o manuscrito da primeira está conservado no Fundo Monteiro Lobato, da Unicamp ${ }^{54}$. Ademais, como Monteiro Lobato não dominava a língua alemã, teria que buscar o texto francês, conforme estuda Lucila Bassan Zorzato. ${ }^{55}$

Segundo Edgard Cavalheiro, a tradução constituiu para Lobato a primeira fonte de renda como atividade intelectual, iniciada quando ele era promotor público na cidade de Areias, no período 1907-1911, e traduzia artigos do londrino Weekly Times para O Estado de S. Paulo. Além de textos em língua inglesa, encarregou-se de trazer para o português: Mémoires (Memórias) de André Maurois, La sagesse et la destinée (A sabedoria e o destino), de Maurice Maeterlinck, Contes de fées (Contos de fadas), de Perrault, Pilote de guerre (Piloto de guerra), de Saint Exupéry e Madame Curie (Madame Curie), de Ève Curie ${ }^{56}$, assunto que será aprofundado no Capítulo 4, "Um Lobato e muitas literaturas".

\footnotetext{
${ }^{51}$ Cf. CANDIDO, Antonio. "O francês instrumento de desenvolvimento" In: CANDIDO, Antonio; CARONI, Ítalo; LAUNAY, Michel. O francês instrumental: a experiência da Universidade de São Paulo. Ed. cit., p. 9-17.

${ }^{52}$ LOBATO, Monteiro. A barca de Gleyre. Ed. cit., p. 59. Carta de São Paulo, 02/06/1904.

${ }^{53}$ IDEM, ibidem, p.173. Carta de Areias, 03/02/1908.

54 “[...] talvez publique a minha tradução do Anticristo do Nietzsche, para a qual já tenho editor. Depende duma correção final do manuscrito que só poderei fazer quando acabar esta minha interminável estada em São Paulo, consumidora de todo o meu tempo em coisas profanas." IDEM, ibidem, p. 239. Carta de São Paulo, 30/07/1910. Manuscrito de $O$ anticristo disponível no CEDAE/IEL/UNICAMP, localização no acervo: código MLb 41 00013.

${ }^{55}$ A relação entre Monteiro Lobato e o universo alemão é discutida em: ZORZATO, Lucila Bassan. A Alemanha de Lobato. In: Anais da X Semana de Letras. 70 anos: A FALE FALA. Porto Alegre: EDIPUCRS, 2010. Disponível em: http://ebooks.pucrs.br/edipucrs/anais/Xsemanadeletras/comunicacoes/Lucila-Bassan-Zorzato.pdf Acesso em: 17 out. 2012.

${ }^{56}$ Cf. BEDÊ, Ana Luiza Reis. Op. cit., p. 64.
} 
É interessante notar que as traduções francesas abrangiam escritores de diferentes nacionalidades. E, pela vez dele, o criador do Sítio do Pica-pau Amarelo teve versões em francês de parte de sua obra. Na dissertação de mestrado A literatura infantil/juvenil brasileira na França: Où est Lobatô?, Vanessa Gomes Franca estuda a inserção do escritor no cenário internacional, sendo traduzido para os idiomas espanhol, russo, inglês, árabe, japonês, alemão, italiano e francês ${ }^{57}$. Em 1921, Lobato informa Rangel do lançamento de Urupês na Argentina, traduzido por Benjamin de Garay e comenta o interesse de tradutores de outros países: "Recebi o Urupês em espanhol lançado na Argentina. Bela edição. Garay. Nos Estados Unidos quer traduzi-lo Isaac Goldberg. E em França, um Julien Fauvel. Livro de sorte." $" 58$

Segundo Vanessa Gomes Franca ${ }^{59}$, em decorrência da preferência dos franceses por escritores regionalistas, Lobato tornou-se um dos autores mais traduzidos nas décadas de 1920 e 1930. Da lista das versões em francês constam os livros Urupés (Urupês) e Le président noir: le choc des races (O presidente negro ou Choque das raças), e contos captados em Cidades mortas e Negrinha; para as páginas dos periódicos Le Monde Nouveau, Revue Nouvelle e Revue de L'Amérique Latine que recebeu maior número de textos. Entre os diversos tradutores estão Gofredo da Silva Telles, G. Le gentil, Sergio Milliet e Jean Duriau,

Em 1967 é publicado La vengeance de l'arbre et autres contes, pelas Editions Universitaires, traduzido por Georgette Tavares Bastos e apresentado por Lucien FarnouxReynaud. Nessa versão estão todos os contos de Urupês: "Les gardiens du phare" ("Os faroleiros"); "Le plaisantin repenti" (“O engraçado arrependido"); "Le couvre-lit de retailles" (“A colcha de retalhos"); "La vengeance du péroba" (“A vingança da peroba”); "Biriba, l'estafette" ("Um suplício moderno"); "Mon conte de Maupassant' ("Meu conto de Maupassant"); "Pollice verso" ("Pollice verso"); "Bucolique" ("Bucólica"); "Le tueur d'arbre" ("O mata-pau"); "Bocatorta" ("Bocatorta"); "L'acquéreur de fazendas" ("O comprador de fazendas"); "Le stigmate", (“O estigma"); "Vieille calamité" ("Velha praga"); "Urupês" ("Urupês"); dois contos de Cidades mortas : "Un homme honnête" ("Um homem honesto"); "Le chef-d'oeuvre du tapeur"; e três contos de Negrinha: "Tranche de vie" ("Fatia

\footnotetext{
${ }^{57}$ FRANCA, Vanessa Gomes. A literatura infantil/juvenil brasileira na França: Où est Lobatô? Dissertação de mestrado (orientação: Ofir Bergemann de Aguiar). Goiânia: Faculdade de Letras, Universidade Federal de Goiás, 2007.

${ }^{58}$ LOBATO, Monteiro. A barca de Gleyre. Ed. cit., p.466. Carta de São Paulo, 10/06/1921.

${ }^{59}$ FRANCA, Vanessa Gomes. Op. cit., p. 64-71.
} 
de vida"); "Les tout petits" (“Os pequeninos”); "Je veux aider le Brésil” (“Quero ajudar o Brasil"). ${ }^{60}$

Duas cartas de Georgette Tavares Bastos, a primeira destinada à Editora Brasiliense e a outra à filha do escritor, Ruth Monteiro Lobato, estão depositadas no Fundo Monteiro Lobato, na Unicamp ${ }^{61}$. As missivas testemunham o contato inicial da tradutora com a família do escritor em busca da autorização para publicar os contos bem como aspectos do preparo da edição francesa de Urupês, integrando a série de obras hispano-americanas nas edições Universitárias, ligada à UNESCO e organizada por Roger Caillois. Embora Fernando Marques do Vale e Nelly Novaes Coelho ${ }^{62}$ afirmem que Monteiro Lobato teve obras infantis traduzidas para o francês, Vanessa Gomes Franca alerta para a ausência de indícios.

O texto mais recente a ganhar versão francesa é o polêmico artigo de Lobato jornalista, n'O Estado de S. Paulo, em 20 de dezembro de 1917: “A propósito da exposição Malfatti (“À propôs de l'exposition Malfatti”), traduzido por Michel Riaudel, em 1987, na revista Modernidade, de Paris.

\footnotetext{
${ }^{60}$ FRANCA, Vanessa Gomes. Op. cit., p. 70.

${ }^{61}$ As imagens digitalizadas das cartas estão no COMPLEMENTO B e C.

${ }^{62}$ VALE, Fernando Marques do. A obra infantil de Monteiro Lobato: inovações e repercussões. Lisboa: Portugalmundo, 1994.

COELHO, Nelly Novaes. Panorama histórico da literatura infantil/juvenil: das origens indo-europeias ao Brasil contemporâneo. 4 ed. São Paulo, Ática, 1991.
} 


\title{
$\underline{\text { O crítico }}$
}

\author{
"Na crítica de arte paulista ele [Lobato] era o mais capacitado e original \\ dos críticos."
}

Tadeu Chiarelli ${ }^{63}$

Das muitas facetas de Monteiro Lobato aquela que causou mais polêmica foi a do crítico. O reconhecimento na imprensa como escritor engajado veio com "Velha praga" e "Urupês", artigos publicados em 1914, n'O Estado de S. Paulo.

No campo da crítica de arte, Monteiro Lobato atuou em São Paulo mais intensamente entre 1915 e 1919. É mais do que conhecido o episódio envolvendo a artista brasileira Anita Malfatti (1889-1964) e a repercussão do artigo “A propósito da Exposição Malfatti”,", retomado sob o título "Paranóia ou mistificação?", em 1919, no livro Ideias de Jeca Tatu. Segundo Tadeu Chiarelli, na história ideal do modernismo não seria interessante reconhecer que Anita Malfatti, considerada a primeira artista moderna brasileira, já se desviara desse caminho, optando por uma produção convencional:

"Já que Lobato não revira seus posicionamentos para aderir ao grupo, vinha muito a calhar a possibilidade de imputar-lhe a responsabilidade pelo recuo de Malfatti, uma vez que ele externara suas opiniões contrárias em relação à arte moderna. Com essa estratégia, Malfatti não corria o risco de ser vista como uma artista moderna arrependida, mas como mártir do movimento." 65

Não se pode negar a importância de Lobato para a crítica de arte militante. Assim como nas páginas de A barca de Gleyre acompanhamos parte do processo da formação literária de Monteiro Lobato enquanto ficcionista, paralela e complementarmente, o perfil de crítico vai se delineando. É evidente que não poderiam faltar referências francesas nessa trajetória.

\footnotetext{
${ }^{63}$ CHIARELLI, Tadeu. Um jeca nos vernissages. São Paulo: EDUSP, 1995. p. 33.

${ }^{64}$ Enio Passiani, no texto "Os duelistas: os confrontos entre Monteiro Lobato e o modernismo na formação do campo literário nacional" aponta alguns intelectuais que propoem uma revisão das ideias estabelecidas quanto ao modernismo, assim retomamos:

CHIARELLI, Tadeu. Um jeca nos vernissages. São Paulo: EDUSP, 1995;

MARTINS, Wilson. História da inteligência brasileira (1915-1933), vol. VI, São Paulo: Cultrix/EDUSP, 1978; SODRÉ, Nelson Werneck. História da literatura brasileira. 9a ed. Rio de Janeiro: Bertrand Brasil, 1995;

NUNES, Cassiano. Novos estudos sobre Monteiro Lobato. Brasília: UNB, 1998;

LANDERS, Vasda Bonafini. De Jeca a Macunaíma: Monteiro Lobato e o Modernismo. Rio de Janeiro: Civilização Brasileira, 1988;

AZEVEDO, Carmen Lucia de; CAMARGOS, Marcia; SACCHETTA, Vladimir. Monteiro Lobato: furacão na Botocúndia. São Paulo: SENAC, 1997.

${ }^{65}$ CHIARELLI, Tadeu. Op. cit., p. 27.
} 


\section{$\underline{\text { O interesse pela França fora dos romances }}$}

Responsáveis pela construção de todo um repertório de conhecimentos históricos, sociais e artístico-culturais, as leituras francesas ocupam lugar privilegiado não só na formação de Monteiro Lobato. Até como retrato de época, a interpenetração da cultura gálica intensifica-se por conta dos estreitos vínculos estabelecidos com a França na Belle époque brasileira, isto é, entre 1889-1922. Cabe ressaltar que, no caso de Lobato, sabe-se que o escritor nunca visitou a França e não se tem notícia de amizades nem de correspondência dele com franceses.

Buscando fontes que lhe permitissem aprofundar seus conhecimentos, a Lobato parece necessário encontrar traços mais humanos e menos literários, como se lê na carta a Godofredo Rangel, em 10 de outubro de 1911:

\footnotetext{
"O que na Revolução Francesa me interessa é o que os estúpidos historiadores à moda clássica não contam. Eu quero fatias de vida da época, conservadas aqui e ali em memórias, em panfletos de despeitados. Interessame o bas-fond da revolução, o formigueiro dos interesses inconfessáveis, a trama secreta dos bastidores, os fios que movimentavam os polichinelos políticos - os subornos. A história fala no patriotismo de Danton, na virtude de Robespierre, mas o que me interessa conhecer é o apetite de Danton, a ambição de Robespierre. Os grandes homens aparecem infinitamente mais interessantes, mais homens, quando despidos das falsas atitudes com que veste a História - esse reposteiro." 66
}

O gosto por uma temática de cunho social, presente em grande parte da produção lobatiana, revela-se, é claro, nas preferências de leitura. Na verdade, Lobato elege um ângulo que o aproxima não só dos acontecimentos mais relevantes como dos bastidores da época; recorre às memórias e aos panfletos. Nesse sentido, o escritor de Cidades mortas antecipa uma tendência cada vez mais adotada por historiadores atualmente: a utilização de memórias, diários e cartas tanto como fonte quanto como objeto de pesquisa.

O fervor pelo material memorialístico acentua-se em 9 de maio de 1913:

"Parece que ando na idade de ler memórias. Só nelas temos o que é possível de história verdadeira, com os bas-fonds e as cozinhas e copas da humanidade. A história dos historiadores coroados pelas academias mostranos só a sala de visitas dos povos. [...] Mas as memórias são a alcova, as anáguas, as chinelas, o pinico, o quarto dos criados, a sala de jantar, a privada, o quintal - a pele quente e nua, ora macia e lisa, ora craquenta de lepra - da humanidade, a grande humanidade com "h" minúsculo, esse

\footnotetext{
${ }^{66}$ LOBATO, Monteiro. A barca de Gleyre. Ed. cit., p. 254-5. Carta de Taubaté, 10/10/1911.
} 
oceano de machos e fêmeas que come, bebe e ama - e supõe que faz mais alguma coisa além disso." 67

A metáfora da casa e seus cômodos reafirma o interesse pela esfera da escrita ligada à intimidade. Aliás, a leitura de cartas é uma prática de que Lobato almeja estender a Rangel quando lhe recomenda a leitura da correspondência de Hippolyte Taine (1828-1893):

"Leio com encanto History of England de Sir Macaulay. E também leio as cartas de Taine. Nelas encontro este juízo, numa a Cornélio de Wit: J'ai lu Macaulay que j'admire infiniment. Merci de cette idée. Para que um dia me agradeças, aconselho-te a leitura dos Essays e também da correspondência de Taine. Outro mártir da má saúde, o Taine - espécie de Adalgiso Pereira. A sua correspondência com E. de Suckau lembra a nossa em certos pontos. Há uma eterna referência a Edmond de About e Prevost-Paradol, como na nossa há uma eterna recorrência do Ricardo e outros." ${ }^{68}$

O livro citado, H. Taine, sa vie et sa correspondance, publicado em 1902, é obra ausente do conjunto de livros que restou das estantes do escritor. Dentre os diversos interlocutores de Taine, Lobato destaca apenas Cornelius de Witt e Édouard de Suckau. Além de conhecer o autor de Urupês como leitor de cartas, cabe analisá-lo no paralelo que faz entre a própria correspondência com Rangel e a de Taine com Suckau. Ao identificar uma característica em comum, Lobato revela-se um aficcionado do gênero e estabelece relações com a construção das próprias memórias epistolares.

Como leitor e crítico iniciante, Monteiro Lobato não só demonstrou interesse pelo movimento naturalista, mas também leu obras de Hippolyte Taine. Em A barca de Gleyre, além das cartas do teórico determinista, são citados Essais de critique et d'histoire, Histoire de la littérature anglaise e Les origines de la France contemporaine.

Na carta de 15 de novembro de 1904, Lobato sugere ao amigo a leitura dos Essais de critique et d'histoire, livro de Taine do qual consta o ensaio "Gleyre" sobre o pintor Charles Gleyre (1808-1874). É a partir dessa leitura crítica do quadro Le soir ou Les illusions perdues que, por meio de metáforas, compara as expectativas de ambos os amigos sobre o futuro. Quanto ao título da coletânea de cartas, Lobato chegara a pensar em Correspondência epistolar entre Lobato e Rangel, conforme relata em carta de 28 de setembro, 1943, e acaba optando pelo metafórico A barca de Gleyre, diálogo focalizado por Emerson Tin:

"Mas por que A barca de Gleyre, se o título original do quadro era Le soir, e ficou conhecido, por força do público, como Les illusions perdues? Aqui novamente se faz sentir a força do texto de Taine: nas 31 páginas de

\footnotetext{
${ }^{67}$ IDEM, ibidem, p. 274. Carta de São Paulo, 09/05/1913.

${ }^{68}$ IDEM, ibidem, p. 415. Carta de São Paulo, 11/12/1917.
} 
seu ensaio sobre Gleyre, nenhuma vez ele alude ao quadro Le soir pelo seu título original, nem pelo título atribuído pelo público. Taine refere-se sempre ao quadro como La barque. Possivelmente, Lobato, ao publicar sua correspondência, tenha relido o ensaio de Taine, e encontrado na metáfora da Barca o título mais expressivo para o volume." ${ }^{69}$

A arte revestida de caráter científico e o rigor formalístico afastam Lobato dos ideais naturalistas. Embora frequentasse a obra de teóricos do movimento na França, entre eles Hipollyte Taine, o "seguidor da veneta", como se classifica, ${ }^{70}$ admite que sua opinião no campo das artes não se pauta por teorizações:

"Na penúltima carta dás como definição de arte do Taine a sua definição de obra d'arte, coisa muito diferente. Definição de arte foi coisa que o sensato e cautelosíssimo Taine teve o espírito de não tentar para não dar a topada que todos os definidores vêm dando desde a Grécia. Todas as definições de arte que conheço degeneram em noção, e isto pelo absurdo de aplicar o processo definitório, coisa puramente científica e lógica, ao fato mais incientífico e ilógico da humanidade - a Arte. ,71

Ainda que a base teórica de Lobato não esteja esmiuçada na correspondência com Rangel, o nome de Taine aparece em diferentes cartas como escritor reconhecido por sua autoridade crítica: "Não concordo com a tua ideia de que todo crítico é um raté da literatura, porque a crítica é um ramo da literatura para o qual certos sujeitos nascem com aptidões especiais. Olhe Taine, Sainte Beuve, Macaulay."72 É também elogiado: [...] estou lendo uma coisa enorme e enormemente boa - As origens da França contemporânea, do Taine" ${ }^{\text {73. }}$.

Além de Hipollyte Taine, outros dois nomes são citados: Anatole France, já referido no presente capítulo porque algumas de suas obras integram o acervo de Monteiro Lobato na Biblioteca Infantil e na Unicamp, e Jules Michelet (1798-1874), da Histoire de la révolution française, um dos primeiros historiadores a se interessar por temas da vida cotidiana. Ao passo que Anatole e Taine são recomendados em diferentes cartas, não há referências em $A$ barca de Gleyre que revelem outras leituras de Michelet. Por sugestão ou não de Lobato,

\footnotetext{
${ }^{69}$ TIN, Emerson. A barca de Gleyre: uma metáfora para a viagem epistolar de Monteiro Lobato e Godofredo Rangel. Intersecções, Revista de estudos sobre práticas discursivas e textuais, a.1, n. 1. Jundiaí, São Paulo, setembro de 2008.2 Disponível em: http://www.anchieta.br/unianchieta/revistas/interseccoes/pdf/Rev_Inter_Emerson_pdf.pdf Acesso em 22 jan. 2013.

${ }^{70}$ Em carta de 30 de janeiro de 1915, Lobato crítica os métodos e afirma: "Meu hábito em tudo é pôr de lado métodos e seguir as intuições da veneta. Acho a veneta algo muito sério e misterioso, Rangel. É como se uma força dentro de nós cochichasse.” LOBATO, Monteiro. A barca de Gleyre. Ed. cit., p. 301. Carta da Fazenda, 30/01/1915.

${ }^{71}$ IDEM, ibidem, p. 85. Carta de Taubaté, 02/02/1905.

${ }^{72}$ IDEM, ibidem, p. 227. Carta de Areias, 23/10/1909.

${ }^{73}$ IDEM, ibidem, p. 265. Carta da Fazenda, 09/04/1912.
} 
sabe-se somente que, do historiador francês, a Companhia Gráfico-Editora Monteiro Lobato lança em 1925 a tradução assinada por Godofredo Rangel do livro La femme (A mulher).

Em se tratando da leitura da obra de críticos n'A barca de Gleyre, é mencionado também Antoine Albalat (1856-1935) em cinco cartas restritas a 1909 e 1914. Lobato toma conhecimento dele por intermédio de amigos e faz uma primeira e superficial análise:

"Esse Albalat que o Ricardo [Gonçalves] te mandou anda interessando muito à rapaziada de São Paulo que pretende lugar nas letras. Tenho a impressão de que é obra vã e perigosa, talvez das que ensinam um certo estilo - e neste caso teremos estilo postiço, como há dentes postiços., ${ }^{, 74}$

Pela escolha da forma “tenho a impressão", infere-se que a crítica precede a leitura, até mesmo porque, dezesseis dias depois, o juízo vago é substituído por um breve comentário que assinala o recebimento do livro: "Veio o 5, acompanhando o Albalat. Comecei a ler este e a gostar". ${ }^{75}$ Sabe-se do costume tanto de Lobato como de Rangel relativo à numeração provisória dos textos que produziam, neste caso, acusando a chegada de um trabalho talvez do autor de Vida ociosa. Portanto, a correspondência revela que a rede de trocas entre os missivistas costumava abranger livros, conhecimentos literários e a própria produção intelectual. Ademais, não só Lobato contribuía com as sugestões de leituras, Rangel possivelmente foi quem lhe sugeriu a leitura de Albalat.

Embora nas cartas d'A barca não haja referência direta ao título de Albalat, é através de um comentário de Lobato acerca da opinião do estudioso sobre Homero que se desvenda essa questão. O título é L'art d'écrire: enseigné en vingt leçons, porém não se pode precisar qual foi a edição à qual ele teve acesso:

“Acabei o Albalat bom, mas de pouco valor para nós aqui. Discreteia sobre o estilo francês, e as coisas mudam quando em português. A parte referente ao estilo descritivo em Homero é ótima e boa para nós. A conclusão que tirei do livro é que estilos não se fabricam, nem se ajustam por influxo de regras; são o que são, como o nariz das pessoas. O mais, arrebiques, sobrecargas, postiços que só aparentemente melhoram o natural ingênito e espontâneo de cada um. Gostei do meu juízo sobre Chateaubriand coincidir com o de Albalat." 76

Nessa época em que Lobato dava seus primeiros passos como escritor e buscava desenvolver-se como ficcionista, nota-se, principalmente nas cartas até 1918, que conhecer o texto de autores de renome também tinha o objetivo de auxiliá-lo na formação do próprio

\footnotetext{
${ }^{74}$ IDEM, ibidem, p. 212. Carta de Areias, 14/08/1909.

${ }^{75}$ IDEM, ibidem, p. 215. Carta de Areias, 30/08/1909.

${ }^{76}$ IDEM, ibidem, p. 225. Carta de Areias, 22/09/1909.
} 
estilo, isto é, por meio de assimilação e apropriação. Tal perspectiva acaba por estabelecer um forte diálogo com o modus operandi adotado por Albalat no manual L'art d'écrire: enseigné en vingt leçons. Dentre os ensinamentos do crítico, estes aproximam Albalat e as práticas adotadas por Lobato:

"Aprender a escrever bem é aprender também a julgar os bons
escritores." 77

"Certamente que não queremos obrigar ninguém a adotar tal ou tal estilo.

"O que aconselharemos é que se decomponham e assimilem todos os estilos, e que depois se forme um deles" 78

"A leitura dos bons autores é, portanto, indispensável para a formação do estilo;" 79

É também no período em que lê Albalat que Lobato está no início de seu encantamento por Camilo Castelo Branco. Na carta de 15 de setembro de 1909, o autor de Ideias de Jeca Tatu revela seu caminho pelos textos do romancista português:

"Mandei vir Noites de insônia, de Camilo, doze volumes, e ainda apanhei uns em Taubaté. E leio anotando os jeitos. Palavras novas não me interessam. A grande coisa não é possuir montes de palavras; se assim fosse, um dicionarista batia Machado de Assis. É saber combinar bem as palavras, como o pintor combina as tintas e o músico o faz às notas. $[\ldots]^{80}$.

Ao relacionar estilo e o bom uso vocabular, Lobato se aproxima do manual de Antoine Albalat, no qual temos a mesma comparação entre o dicionarista e o artista:

"O estilo é a arte de aprender o valor das palavras e as relações das palavras entre si.

"As ideias simples, representadas pelas palavras do dicionário, em número somente de umas 17.000, não bastam para fazer um escritor.

"Aquele que conhecer essas 17.000 palavras poderá, não obstante, ser incapaz de traçar uma frase.

"O talento não consiste em nos servirmos secamente das palavras, mas em descobrir as imagens, as sensações e os cambiantes, que resultam das suas combinações." ${ }^{\natural 1}$

Portanto, ao anotar os "jeitos", Lobato estaria exercitando a formação de seu estilo, aprendendo não só o valor das palavras, mas a possibilidade de combinações.

\footnotetext{
77 ALBALAT, Antoine. A arte de escrever: ensinada em vinte lições. Tradução de Cândido de Figueiredo. Lisboa: Livraria Clássica, 1948, p.8.

${ }^{78}$ IDEM, ibidem, p. 18.

${ }^{79}$ IDEM, ibidem, p.32.

${ }^{80}$ LOBATO, Monteiro. A barca de Gleyre. Ed. cit., p. 223. Carta de Areias, 15/09/1909.

${ }^{81}$ ALBALAT, Antoine. Op. cit., p.42.
} 
Lobato tira proveito do manual e compartilha as lições com o amigo. Conclui que os estilos literários são traços do caráter individual de um escritor, não podendo ser construídos ou modificados. Nota-se que a ideia de particularidade artística na criação permanece ao longo da correspondência. Nesse sentido, a leitura permite assimilar modelos estilísticos e auxilia na construção da própria identidade literária, distinguindo apropriação de imitação.

Do mesmo modo que, ao tratar dos autores franceses no presente capítulo fez-se um recorte, optou-se por analisar os referenciais críticos citados que apresentavam comentários mais substanciosos da parte de Monteiro Lobato e não apenas breve menção a nomes em meio às cartas, indicada a simples passagem por Émile Faguet (1847-1916), Sainte-Beuve (18041869) e Ernest Renan (1823-1892), sem particularizar títulos.

\section{$\underline{\text { Das leituras fez-se o crítico }}$}

“Ai! Quando nos virá a esplêndida coragem de sermos nós mesmos, como o francês tem coragem de ser francês, e o inglês a de ser inglês, e o alemão a de ser alemão?

"Quando? Quando?"

Monteiro Lobato ${ }^{82}$

Amparando-se nas referências em cartas a Godofredo Rangel, ao longo do capítulo, foram selecionados e analisados excertos representativos da relação de Monteiro Lobato com a França, principalmente no que concerne ao tratamento dado à literatura francesa em sua formação de escritor e ao seu desenvolvimento crítico enquanto leitor. Deste modo, com a finalidade de complementar a leitura de A barca de Gleyre e ampliando o estudo das marcas francesas em Lobato, recorre-se a seus títulos Ideias de Jeca Tatu cuja primeira edição é da Revista do Brasil em 1919, e Na antevéspera, lançado em 1933 pela Companhia Editora Nacional, por reunirem artigos que expressam incisivamente sua opinião sobre o afrancesamento da sociedade brasileira.

\footnotetext{
${ }^{82}$ LOBATO, Monteiro. “Arte brasileira”. In: Ideias de Jeca Tatu. São Paulo: Brasiliense, 1950, p.196.
} 
O artigo "Estética oficial", em Ideias de Jeca Tatu, posiciona-se perante o envio de brasileiros para estagiar na França, questão já discutida em "Pensionamento de artistas", n'O Estado de S. Paulo em 16 de janeiro de $1916^{83}$. Uma leitura isolada do fragmento "[...] para a imbecilidade nacional o mundo é ainda a França." ${ }^{84}$, poderia concluir que Monteiro Lobato é adverso à presença francesa no Brasil. Todavia, aqueles que conhecem A barca de Gleyre e se encontraram com o número expressivo de menções ao universo francês, indagam-se: Como o Lobato das cartas, leitor de escritores franceses e conhecedor da cultura gálica, dialoga com o Lobato dos artigos de crítica? Distancia-se ele da opinião expressada em sua correspondência? Como se processa a crítica lobatiana à França?

Embora não se possa negar certo tom galófobo no discurso de Lobato, cabe discutir que essa tensão, na verdade, advém de uma reação de recusa da galicização e associa-se a um impulso de busca da afirmação nacional, na qual um número considerável de intelectuais brasileiros estava engajado; entre eles, Mário de Andrade.

Leyla Perrone-Moisés traça um retrato da sociedade nesse período de acentuada atração pela cultura francesa:

"No fim do século XIX, a influência francesa sobre os intelectuais, e em todos os domínios da vida cotidiana das elites, é maior do que nunca. $\mathrm{O}$ positivismo de Auguste Comte é a ideologia inspiradora de nossa República, instalada ao som da Marseillaise. A viagem a Paris torna-se obrigatória no currículo de toda pessoa civilizada. Entretanto, na medida em que essa mesma elite persiste em seu desígnio de consolidar a nação brasileira e de dar a esta uma cultura própria, manifesta-se cada vez mais a recusa da imitação pura e simples da França.

"A fundação da Academia Brasileira de Letras, em 1896, é um dos exemplos mais claros dessa submissão, alternada com recusas. Fundada com um objetivo nacionalista, que consistia antes de mais nada na fixação da língua nacional, já emancipada do português metropolitano, nossa Academia foi no entanto criada como uma cópia fiel da Academia Francesa.[...]

"O francesismo da Belle Époque era uma imitação servil, por vezes ridícula. Os brasileiros abastados queriam vestir-se com a última moda de Paris e ler os livros que lá se editavam. Companhias teatrais francesas, desde o século XIX, faziam turnês periódicas no Rio e em São Paulo, e conferencistas franceses eram acolhidos com entusiasmo nas duas cidades ${ }^{\prime 85}$.

83 Texto disponibilizado no acervo digital do jornal $O$ Estado de $S$. Paulo. Disponível em: http://acervo.estadao.com.br/pagina/\#!/19160116-13537-nac-0003-999-3-not. Acesso em: 17 mai. 2013.

${ }^{84}$ LOBATO, Monteiro. "Estética oficial”. In: Idéias de Jéca Tatu. Ed. cit., p. 46.

${ }^{85}$ PERRONE-MOISÉS, Leyla. "Galofilia e galofobia na cultura brasileira”. In: Vira e mexe, nacionalismo: paradoxos do nacionalismo literário. Ed. cit., p. 62 e 67-8. 
Em Ideias de Jeca Tatu, a relação idílica com a França já era denunciada por Lobato em 1919:

"Vem daí o fato estranho, a quem corre o olhar pelas paredes das nossas casas ricas, de vê-las coalhadas de quadros franceses no estilo e no assunto, apesar de rubricados por nomes nacionais.

"Salas há onde o visitante, se fechar as janelas para não ver os plátanos bichados da rua, e os ouvidos para não ouvir o 'batata assada ao forno', jura estar em Paris pelo menos.

"São marinhas de Concarneau, cenários da Costa Azul, trechos da Bagatelle, estudos de boulevards, bretanhices a granel, perdões, pescarias, mulheres de coifa...

"E tudo nomeado à francesa, basse-cour, étang, vieille cour, vieux moulin e outras sonoridades de encher o ouvido." ${ }^{86}$

É justamente essa sujeição aos modelos franceses em detrimento da afirmação da identidade cultural brasileira que Monteiro Lobato combate. Logo no prefácio da $1^{\mathrm{a}}$ edição de Ideias de Jeca Tatu (reproduzido nas demais edições) a tônica do livro é o debate em torno da imitação bajuladora, da macaqueação das ideias francesas:

"Uma ideia central unifica a maioria destes artigos, dados à estampa em O Estado de S. Paulo, na Revista do Brasil e em outros periódicos. Essa ideia é um grito de guerra em prol da nossa personalidade... A corrente contraria propugna a vitória do macaco. Quer, no vestuário, a cinturinha de Paris; na arte, 'aveuglesnés'; na língua, o patuá senegalesco. Combate a originalidade como um crime e outorga-nos, de antemão, o mais cruel dos atestados: és congenialmente incapaz duma atitude própria na vida e nas artes; copia, pois, ó imbecil!

"Convenhamos: a imitação é, de feito, a maior das forças criadoras. Mas imita quem assimila processos. Quem decalca não imita, furta. Quem plagia não imita, macaqueia. E o que os paredros do 'dernier cri' fazem não passa de caretas, guinchos, pinotes de monos glabros em face dos homens e das coisas de Paris.

“- Macaquitos, então?

“- Upa! Macacões!

"Jéca Tatú, coitado, tem poucas ideias nos miolos. Mas, filho da terra que é, integrado como vive no meio ambiente, se pensasse, pensaria assim. Justifica-se pois o título." 87

Ao tecer sua crítica com o objetivo de "grito de guerra em prol da personalidade brasileira", Lobato acredita no próprio papel ativo nesse enfrentamento da penetração da França não só no campo das artes, mas no comportamento, nos ideais... na cultura brasileira.

\footnotetext{
${ }^{86}$ LOBATO, Monteiro. "Estética oficial”. In: Ideias de Jeca Tatu. Ed. cit., p. 47-8.

${ }^{87}$ IDEM. "Prefácio da $1^{\mathrm{a}}$ edição". In: Ideias de Jeca Tatu. Ed. cit., p. XI.
} 
Com o intuito de explicar a escolha do título do livro, o autor evoca Jeca Tatu, personagemsímbolo não só da sua obra, mas de toda uma fase da literatura brasileira ${ }^{88}$, de modo que, personagem e escritor se fundem, tornando Lobato um porta-voz do Jeca e de suas ideias. Há também nesta escolha uma crítica ao próprio povo brasileiro que, nascido como o Jeca, "filho da terra e integrado como vive no meio ambiente", deveria posicionar-se pela independência cultural de seu país e não pela subserviência, pois o Jeca, que é menos esclarecido, assim pensaria/se posicionaria, como Lobato.

O termo "macaquear" e suas variações são retomados em diversos textos lobatianos quando o assunto é a reprodução servil dos modelos franceses. Além disso, é interessante notar a distinção estabelecida entre imitação, decalque e plágio, sendo que para Lobato a primeira é aceitável por reconhecer a assimilação/ apropriação como parte do processo criativo, prática esta por ele adotada.

No artigo "Estética oficial", Lobato valoriza o trabalho artístico vinculado às feições nacionais ao pontuar que “[...] o artista cresce à medida que se nacionaliza. É mister que a obra d'arte denuncie ao mais rápido volver d'olhos a sua origem, como as raças denunciam pelo tipo individual o grupo etnológico." ${ }^{89}$

O Pensionato Artístico, comandado pelo mecenas José de Freitas Valle, de 1912-1930, é questionado por ir contra os ideais de uma formação nacional:

"Pega o Estado no rapaz, arranca-o da terra natal e dá com ele no Quartier Latin, com o peão da raiz arrebentado.

"A mentalidade em formação do adolescente, assim desramada e desraigada, padece grave traumatismo, lá perde a seiva preciosa do habitat e vai viver em vaso sob clima hostil à sua regionalidade.

"Durante a estadia de aprendizagem só vê a França, só lhe respira o ar, só conversa mestres franceses, só educa os olhos em paisagem francesa, arte francesa, museu francês. [...]

"Concluindo o tirocínio, há duas sendas para o transplantado: ou ficar por lá, perdido na turba dos artistas exóticos que atravancam Paris, incapaz de emparelhar com os nativos, porque o inferioriza uma alma de empréstimo, ou torna cá, tombado para a categoria do 'expatriado artístico'.

“A sua pátria estética lá ficou - a França, reconhece-o ele.

\footnotetext{
${ }^{88}$ AZEVEDO, Carmen Lúcia de; CAMARGOS, Márcia; SACCHETTA, Vladimir. Monteiro Lobato: furacão na Botocúndia. São Paulo: SENAC, 1997, p. 58.

${ }^{89}$ LOBATO, Monteiro. "Estética oficial”. In: Ideias de Jeca Tatu. Ed. cit., p. 45.
} 
"Os débeis entram a malsinar das nossas coisas. O céu é estupidamente azul. O azul é absurdo, irreproduzível na tela. $O$ verde não tem fim. A cor é excessiva. Não há cambiantes. Não há árvores pitorescas. Não há gente. Não há costumes. Não há mulheres. E suspiram, com o olho da saudade fito na pequena que os enfeitiçou por lá: - 'Ah, Paris! Paris!'

"Os fortes compreendem de relance a situação, atinam com a senda verdadeira e entram a estudar de novo, deitando às urtigas metade das ideias bebericadas fora. Redimem-se, estes." 90

Nesta visão, a instrução francesa oferece apenas duas possibilidades malogradas: a permanência do artista na França, relegado por não pertencer social e culturalmente à nova pátria; a volta ao Brasil dotado de instrumental francês, de modo que a única alternativa para produzir uma arte nacional seria libertar-se da formação estrangeira recebida. Assim, qualquer que fosse a influência de outras culturas culminaria na produção de uma obra não genuinamente brasileira. Na verdade, o embate de Lobato prende-se ao fato de que "A França era o novo modelo que a jovem nação opunha ao modelo colonial português, na qualidade de país da liberdade (recentemente conquistada por nós), das Luzes (desejadas) e da própria idéia de nação. Em vez de estudar em Coimbra, como antes, os jovens brasileiros começam a ir para Paris." 91

Novamente o tom antigalicista marca a tomada de posição na busca da brasilidade:

“[...] à luz do ponto de vista brasileiro era de desejar que a França fosse tragada por um maremoto afim de permitir uma livre e pessoal desenvoltura à nossa individualidade. Porque ela está nos pondo 'faisandés' antes do tempo.

"Que lindo se figurássemos na assembleia mundial como povo capaz de uma ideia sua, uma arte sua, costumes e usanças que não rescendam a figurinos importados!

"Enerva a persistência na macaquice." $" 92$

Em "Arte brasileira", artigo no livro Ideias de Jeca Tatu, inserido nas Obras completas em 1946 (não foi encontrada referência a uma publicação anterior), Lobato continua a defender liberdade do artista:

"De que maravilhosas coisas o brasileiro não seria capaz se o não fincasse no terreno do pastiche o inibitório terror à mofa escarninha do francês! O que nos mata é o francês! Nós temos a obsessão do francês" ${ }^{, 93}$.

\footnotetext{
${ }^{90}$ LOBATO, Monteiro. "Estética oficial”. In: Ideias de Jeca Tatu. Ed. cit., p. 46.

${ }^{91}$ PERRONE-MOISÉS, Leyla. "Galofilia e galofobia na cultura brasileira”. In: Vira e mexe, nacionalismo: paradoxos do nacionalismo literário. Ed. cit., p. 57.

${ }^{92}$ LOBATO, Monteiro. "Estética oficial”. In: Ideias de Jeca Tatu. Ed. cit., p. 48-9.

${ }^{93}$ IDEM. “Arte brasileira”. In: Ideias de Jeca Tatu. Ed. cit., p. 192.
} 
O livro Na Antevéspera, publicado em 1933, com o subtítulo "Reações mentais dum ingênuo", reúne artigos de Lobato de diferentes épocas, alguns do tempo de estudante no Largo São Francisco (1900-1904), outros para os diários cariocas O Jornal e A Manhã, entre 1925 e 1927, e mais textos que acrescem as Obras completas, organizada e revista pelo próprio autor e publicada pela editora Brasiliense, em 1946. Na nota dos editores desta última, a entrada desses artigos remotos justifica-se na necessidade de equilibrar a matéria dos vários volumes.

Em “O nosso dualismo", no Diário da Noite, em 1926 (São Paulo, 20 de março), posteriormente inserido na coletânea $\mathrm{Na}$ antevéspera, o escritor discute aspectos do movimento modernista e do futurismo trazido, segundo ele, por Oswald de Andrade (18901954); o que Mário de Andrade nega no artigo "Post-Scriptum Pachola", no suplemento de $A$ Manhã, em 13 de maio de $1926 .^{94}$

Um dos assuntos abordados no artigo lobatiano é a submissão nacional aos modelos franceses e a presença portuguesa ainda fortemente marcada na língua:

"Porque é estranho isto de permanecermos tão franceses pela arte e pensamento e tão portugueses pela língua, nós, os escritores, nós, os arquitetos da literatura, quando a tarefa do escritor de um determinado país é levantar um monumento que reflita as coisas e a mentalidade desse país por meio da língua falada nesse país.

"Formamos, os escritores, uma elite inteiramente divorciada da terra, pelo gosto literário, pelas ideias e pela língua. Somos um grupo de franceses que escrevem em português" ${ }^{95}$.

Lobato não só defende a personalidade nacional, como assinala o próprio papel enquanto intelectual e escritor na afirmação identitária do Brasil. Para ele, é preciso expressarse segundo os costumes de seu país, logo, na construção de uma literatura que reflita tanto a temática quanto a língua desta nação. Nesse sentido, não se pode deixar de reconhecer a relação com Mário de Andrade cujo projeto nacionalista crítico abrangia também a tarefa de nacionalizar a linguagem, como se testemunha na correspondência com Manuel Bandeira (1886-1968) e se verifica na Gramatiquinha da fala brasileira ${ }^{96}$.

\footnotetext{
${ }^{94}$ ANDRADE, Mário de. "Post-scriptum pachola”. In: Revista Cult, n. 57, ano 5, São Paulo, maio /2002.

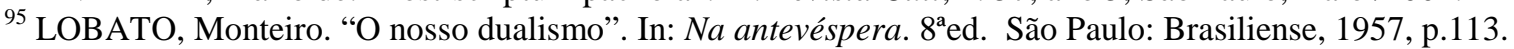

${ }^{96}$ ANDRADE, Mário de; BANDEIRA, Manuel. Correspondência Mário de Andrade \& Manuel Bandeira. Organização, introdução e notas de Marcos Antonio de Moraes. São Paulo: Edusp/IEB, 2000.

ANDRADE, Mário de. A gramatiquinha da fala brasileira, na série Manuscritos Mário de Andrade, no arquivo do escritor, no IEB/USP.
} 
O desejo de uma dimensão brasileira da língua portuguesa é expresso não só neste artigo como em diferentes momentos da obra lobatiana. Cabe notar que esse enfrentamento da herança lusitana inicia-se por volta de 1917-1920, quando Lobato não mais procurava se pautar em escritores portugueses quanto ao aprendizado da língua e dá sinais de rejeição à gramática.

Para finalizar, o texto "Curioso caso de materialização", crônica com traços de ficção, posta em meio aos artigos de Ideias de Jeca Tatu, aborda com humor o afrancesamento da cultura nacional. Nessa narrativa, Camilo Castelo Branco (1825-1890), o autor português mais admirado por Lobato, encontra-se numa praça paulistana. A partir do anúncio de um restaurante colado em meio ao à crônica, impregnado de modismos franceses e ingleses, nem todos corretamente grafados, Camilo questiona nossa identidade e crítica o brasileiro que, numa referência à teoria evolucionista de Charles Darwin (1809-1882), ao invés de evoluir, retrocede ao seu passado primata, associação resultante do termo macaquear.

Enfim, nas cartas e nos artigos apresentados, não se pode falar no perfil de Lobato enquanto leitor sem uma tentativa de organizar os diversos perfis de leitura modificados no decorrer da vida dele. Deste modo, a escolha de abordar primeiro os escritores franceses norteou-se pela própria correspondência reunida em A barca de Gleyre e a aproximação aos modelos portugueses, como se observa, cresceu com o passar dos anos. Assinala-se, inclusive, que isto não impossibilita que Lobato leia os escritores franceses ao mesmo tempo em que prefere Camilo Castelo Branco e vice-versa.

E por falar em Camilo, vamos às leituras em língua portuguesa!

\footnotetext{
${ }^{97} \mathrm{O}$ texto se encontra digitado em COMPLEMENTO D presente no final do trabalho.
} 


\section{Capítulo 2}

\section{Um Lobato de cá e um português de lá...}

“[...] em matéria de língua minha base de operações é Camilo.”

Monteiro Lobato ${ }^{1}$

A rede de sociabilidade nas trocas, tanto de livros como de conhecimentos literários, estabelecida com Godofredo Rangel, permite explorar aspectos relacionados ao lado leitor de Monteiro Lobato. As cartas mostram um escritor em formação que exercita seu senso estético nas leituras que comenta e sugere ao amigo.

Se as referências francesas marcam os primeiros anos da correspondência entre Monteiro Lobato e Godofredo Rangel, vire algumas páginas e pule alguns anos, assim terá em A barca de Gleyre a faceta de um jovem escritor fascinado pelo estilo literário de Camilo Castelo Branco.

É a partir de 1909 que a literatura portuguesa ganha maior espaço nesse jogo epistolar, tendo Camilo Castelo Branco um papel de destaque colocado pelo próprio Lobato. Contudo, desde 1903, outros autores portugueses aparecem nas páginas d'A barca; alguns apenas uma vez, outros com mais referências. Desse modo, encontram-se: Eça de Queirós, Alexandre Herculano, Oliveira Martins, Luís de Camões, Bocage, Fialho d'Almeida, Frei Luís de Sousa, Almeida Garrett, Carlos Malheiro Dias, Eugénio de Castro, João de Lucena, Pedro Antônio Correia Garção, Pe. Antônio Vieira, Antônio Feliciano de Castilho, Pe. Manuel Bernardes, Nicolau Tolentino de Almeida, Francisco Manoel, Teixeira de Pascoais e outros.

Embora admita não ter conseguido terminar a leitura d'Os Lusíadas, após cinco tentativas $^{2}$, Lobato elogia a poesia de Camões. Abre a carta de 15 de outubro de 1906 com os versos "Olhos sossegados,/ Pretos cansados." e deseja que Rangel adivinhe de quem é a

\footnotetext{
${ }^{1}$ LOBATO, Monteiro. A barca de Gleyre. Ed. cit., p. 342. Carta da Fazenda, 20/01/1916.

2 "O próprio Lusíadas nunca li inteiro. Cansa-me. Já investi contra o bloco cinco vezes. Começo achando-o belíssimo, e vai belíssimo até dez ou doze estrofes; daí por diante entram a amiudar-se os bocejos e a admiração vai morrendo. $\mathrm{Na}$ estrofe $16^{\mathrm{a}}$ volto as páginas para ver se o fim do canto ainda está muito longe. $\mathrm{Na} 20^{\mathrm{a}}$ acho meios de interromper a ingestão da obra-prima e encostá-la por seis meses ou um ano. Mas é admirável o Camões, não resta a menor dúvida. Nós é que somos uns fracalhões, uns dispépticos, uns degenerados netos de truculentíssimos avós. Um dos nossos antepassados, Cunhambebe, comia um português inteiro sem arrotar. Nós mal escoramos uma asinha de frango...”. IDEM, ibidem, p. 106. Carta de Taubaté, 15/03/1906.
} 
autoria. Mesmo que o autor de Urupês não tenha se dedicado ao gênero, seus comentários indicam que seu senso estético é sensível à poesia:

"Não prefiro a poesia antiga à moderna, nas acho na antiga um sabor mais amável, qualquer coisa como o cheiro dos velhos casarões de fazenda que a caseira abre para nos receber. A cor e o sabor da poesia moderna são mais ricos de torturas, têm mais pensamento, denotam mais matéria cinzenta no cérebro humano e isso nos agrada, a nós complicados homens de agora. A antiga dá ideia de pés em sandálias."

Em Areias, no cargo de promotor público, escreve carta em janeiro de 1910 abordando sua predileção pela língua e a literatura portuguesa:

"Vai por quatro o número de vezes que me ponho a escrever e estarrecese-me em meio a pena, tolhida de súbita vergonha. É o caso que leio e leio e leio Camilo, com o afã dum Henry Morgan a remexer as arcas de um galeão espanhol capturado no mar dos Caraíbas. Leio-o e penetro-me de Camilo, ensaboo-me com as riquezas do maior sabedor da língua d'aquém e d'além mar, Algarves e Colônias; e, com a 'descoberta' que fiz do que realmente é a língua portuguesa, espanto-me do atrevimento da filha bastarda que vingou vicejar nestas paragens, tomou-lhe o nome e vive a dar-se como sua sucessora!

“[...] aprendi por cá uma língua bunda pensando que era a nobre e fidalga língua portuguesa." 4

Recorre aos autores portugueses como meio de aprofundar seu aprendizado da língua.

Critica o português do Brasil, principalmente aquele que observa na escrita jornalística:

"Meu estudo de português continua, mas em tom mais baixo. Tenho um inimigo à ilharga, que desfaz o que Camilo faz. É o jornal. Não dispenso a leitura de três ou quatro desses infames massacradores da língua. Mas exercem uma função boa. Impedem-nos de nos afastarmos muito da realidade. Mesmo assim eu desejaria dispensá-los por uns anos., ${ }^{5}$

A dificuldade de uma escrita em língua portuguesa à maneira de Camilo Castelo Branco assusta o jovem escritor "Após um mês de paixão por Camilo - paixão cega e que me tomava os dias inteiros - engulhei, e engulhado estou até agora. Voltei ao desenho. Há duas semanas não faço outra coisa" ${ }^{6}$. Logo, a grande admiração pelo autor português não só o aproxima da língua e da literatura portuguesa, como o afasta momentaneamente da escrita literária.

\footnotetext{
${ }^{3}$ IDEM, ibidem, p. 127. Carta de Taubaté, 15/10/1906.

${ }^{4}$ IDEM, ibidem, p. 233-4. Carta de Areias, 12/01/1910.

${ }^{5}$ IDEM, ibidem, p. 202. Carta de Areias, 01/07/1909.

${ }^{6}$ IDEM, ibidem, p. 193. Carta de São Paulo, 02/01/1909.
} 
Se por um lado as leituras em língua francesa são interrompidas, manifesta-se um Lobato leitor de clássicos portugueses, preocupado com o estudo da língua e com um bom modelo linguístico, como afirma: "Parei com as minhas leituras de língua estrangeira. Não quero que nada estrague minha lua de mel com a língua lusíada"7. A entrega à literatura portuguesa e aos exames linguísticos é confiada ao amigo:

"Sempre vivi nesse elegante atascal da língua francesa, no qual me cevava de literaturas exóticas, eslava, britânica, escandinava e até hindustânica - sem me lembrar que isso só deve ser permitido aos que já perlustraram a fundo as províncias da literatura pátria. E tão encrostado me pôs o longo patinhar por anos a fio nesse engano ledo e cego, que não creio em cura para o mal. Tenho sífilis no idioma, da incurável! Mas é provável que encetando agora o estudo da Grande Língua, aos 80 anos menos leigo serei de suas louçanias que hoje. E como ajustado ao intento me pareceu Camilo, a ele me arremeti. Fiz vir um fardel de cinquenta volumes, que trago (tragar, engolir) em parcelas de meio por dia. E espero encomendas feitas a várias livrarias lusitanas, que me abasteçam de Francisco Manoel, um sujeito que deve valer muitos Stendhais e Taines. E de Almeida Garrett, o visconde resgatador de todas as alimarias viscondadas, baronadas, acondadas, marquesadas com que o moderno Portugal atravancou o mundo. E de mais Camilo, Herculano, e Tolentino, e Garção... Que coorte!

"E enquanto de todos me não tornar amigo íntimo em diurno e noturno conversar, protesto não admitir amizades bárbaras (no sentido romano, isto é, estrangeiras). Não me mandes, pois, o teatro francês, que te delicia; muito tempo hei perdido com esses deliciosos pechisbeques - cocadas que atendem ao paladar mas empecem a alma."

Neste sentido, Regina Helena Pires de Brito, em “A influência de autores estrangeiros em Lobato e a constituição da Brasilina", delineia esta trajetória no tocante às relações lobatianas com a língua e literatura portuguesa:

“- 1903-1908: período de alheamento com relação ao estudo da língua portuguesa;

“- 1909-1913: introdução da literatura portuguesa às suas leituras estrangeiras;

“- 1915-1917: preocupação extrema com o estudo da língua portuguesa via literatura;

\footnotetext{
${ }^{7}$ IDEM, ibidem. p. 222. Carta de Areias, 15/09/1909.

${ }^{8}$ IDEM, ibidem, p. 233-4. Carta de Areias, 12/01/1910.

${ }^{9}$ No artigo "A influência de autores estrangeiros em Lobato e a constituição da Brasilina", Regina Helena Pires de Brito analisa as referências aos autores portugueses, encontradas em A barca de Gleyre, mais especificamente, a relação de Monteiro Lobato e a língua portuguesa. O estudo das cartas revela como Lobato se mostrou a favor de um modelo de língua adaptado à realidade brasileira, pautando-se nos "bons" autores estrangeiros (portugueses), numa tentativa de os assimilar e atingir o "nosso" uso.

Regina Helena Pires de. A influência de autores estrangeiros em Lobato e a constituição da Brasilina. Revista do GELNE. v. 4, n. 2, [S.1], 2002. Disponível em: 〈http://www.gelne.ufc.br/revista_ano4_no2_21.pdf >. Acesso em: 11 ago. 2010.
} 
“- 1917-1920: sinais de rejeição da gramática portuguesa;

“- 1921/22: dialeto, com possibilidade de vir a ser língua: a Brasilina." 10

Entusiasmado com a leitura de $O$ dialeto caipira, de Amadeu Amaral, Lobato envolvese com a ideia de uma dimensão brasileira da língua portuguesa, pautada na fala do povo, o que culmina com a brasilina, denominação usada, pela primeira vez, em 1921, no livro $A$ onda verde:

"Não obstante a menina cresce, aconchegada com amor no seio do povo. Já é ela, a neta, e não mais a avó erudita, quem satisfaz às necessidades de intercambio mental dos roceiros, das patuleias urbanas e dos literatos que se dirigem às massas e não às elites. Nela é que o sertanejo ama, o gaúcho bravateia, o retirante chora, o seringueiro lamenta-se, o vaqueiro descanta, o cafajeste pernostica. Tem já poetas embelecados pelas suas graças nascentes, e adoradores prosistas, doidos pelo seu linguajar langue, ingênuo, expressivo e vivamente impregnado da cor, do som, do cheiro, do itê, do agreste da terra brasílica.

“[...] E a velha língua-mãe, que cá vige mas não viça, abdicará de vez na filha espúria que hoje renega, e desconhece, e insulta como corruptora da pureza importada.

"Cem anos levará isso? Que importa? Cem, duzentos, quinhentos - isso é nada na vida de um povo. E sinhazinha Brasilina não tem pressa."

Essa relação estabelecida com a língua modifica-se ao longo dos anos ${ }^{12}$. Se, em 1921, sua consciência linguística lhe permite escrever sobre a brasilina, em 1909, Lobato estava apenas principiando os estudos linguísticos. Impulsionado pelo universo lusófono, escreve diversas cartas que testemunham o empenho dele no contato com a língua portuguesa via literatura. Na carta de 15 de setembro, 1909, refere-se ao emprego do idioma de Frei Luís de Sousa como o modelo linguístico que procura:

“Nós não sabemos essa maldita língua, Rangel, e manejamos
achavascadamente, plebeiamente, um barro, um caulim de primeira, com o
qual se podem modelar as mais leves e finas coisas. Só agora ando
alcançando a extensão do meu erro nesse ponto. Até aqui me repastei, quase
que exclusivamente, no francês, e 'ouvia falar' da 'língua de Frei Luís de
Sousa'. Meu português era o caseiro e do jornal. E eu ficava de olho grande:
'Que linda não há de ser, meu Deus, a língua de Frei Luís de Sousa!'. Mas
não tinha coragem de investigar. Agora, sim, a coragem me veio e entrei.

\footnotetext{
${ }^{10}$ BRITO, Regina Helena Pires de. A influência de autores estrangeiros em Lobato e a constituição da Brasilina. Revista do GELNE. v. 4, n. 2, [S.1], 2002. Disponível em:〈http://www.gelne.ufc.br/revista_ano4_no2 21.pdf>. Acesso em: 11 ago. 2010

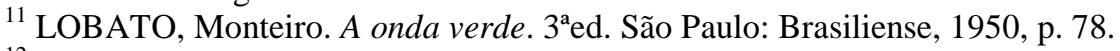

${ }^{12}$ No artigo "Exatidão e liberdade na linguagem de Monteiro Lobato", Maria Zélia Borges aborda a preocupação do escritor com a língua, incluindo os diferentes posicionamentos em relação à gramática ao longo da vida.

Cf. BORGES, Maria Zélia. Exatidão e liberdade na linguagem de Monteiro Lobato. Todas as Letras, v. 1, n.1, São Paulo, 1999. Disponível em: http://www3.mackenzie.br/editora/index.php/tl/article/view/877/630. Acesso em 15 jul. 2012.
} 
Estou, Rangel, dentro da língua de Frei Luís, embora ainda longe de lá do centro, onde ele deve figurar como um Deus, com Herculano à mão direita e Camilo à esquerda. [...]",

Descobre nos clássicos o exemplo a seguir, o estilo a ser trabalhado. A fruição literária associa-se ao aprendizado, de modo que a seleção de textos pauta-se por um modelo linguístico a ser conquistado. Na mesma carta de 15 de setembro de 1909, o autor de Cidades mortas comenta com o amigo as leituras recentes:

"Mandei vir Noites de insônia, de Camilo, doze volumes, e ainda apanhei uns em Taubaté. E leio anotando os jeitos. Palavras novas não me interessam. A grande coisa não é possuir montes de palavras; se assim fosse, um dicionarista batia Machado de Assis. É saber combinar bem as palavras, como o pintor combina as tintas e o músico o faz às notas. [...]

"Já li um volume das Lendas e narrativas de Herculano e releio o ultrabom Eusébio Macário de Camilo - Camilo a fazer fosquinhas para os naturalistas! E tenho um livro de Frei Luís, uma hóstia sagrada, Rangel: Anais de D. João III. O Nó Vital é ali com esse frade, o verdadeiro dono moral da língua. Quantas vezes eu tinha lido, 'A língua de Frei Luís de Sousa'... Ando por Herculano, Camilo e outros, como quem anda sobre as lages que se aproximam do templo." 14

Ao longo das missivas, captam-se elementos do perfil de Monteiro Lobato como leitor, principalmente nos momentos em que ele apresenta a Rangel a imagem por ele traçada do próprio processo de leitura. O modo como lê, fazendo anotações daquilo que denomina "jeitos", evidencia a postura do leitor que lança seu olhar ao texto como um espaço de estudo; despende esforços na construção de seu próprio estilo por meio do exame da escrita de outros autores.

Mesmo em meio à rotina de fazendeiro, derivada da herança em 1911 de terras de seu avô, o Visconde de Tremembé, Lobato acha tempo para mergulhar nos livros. Na carta de 16 de janeiro de 1915, detalha o processo de aprendizagem e de construção do próprio estilo, esmiuçando o mecanismo da apropriação:

"Minhas incursões pelos romances do Camilo têm duas intenções: uma, passarinhar naquela desordenada mata virgem, apanhando as boas locuções que não tenho em meus viveiros; outra, mariscar os idiotismos, que são as pérolas da língua. E também me é um descanso andar pela floresta do grande malabarista - descanso desta nossa crise monetária de vocábulos e graça, que nos envolve neste país em que a leitura do jornal mata a do livro. Não há livros, Rangel, afora os franceses. Nós, precisamos entupir este país com uma chuva de livros. 'Chuva que faça o mar, germe que faça a palma', já o queria Castro Alves.

\footnotetext{
${ }^{13}$ LOBATO, Monteiro. A barca de Gleyre. Ed. cit., p. 222. Carta de Areias, 15/09/1909.

${ }^{14}$ IDEM, ibidem, p. 223. Carta de Areias, 15/09/1909.
} 
"Na tua carta levas ao extremo o estudo camiliano. Levas ao extremo de esfarelá-lo num glossário metodicamente disposto para a rebusca de frases feitas. Condenas aquele meu terreirinho limpo onde caiam as sementes que o vento traz. Com o teu sistema de glossário, sabe o que acontece? Tornamonos uns Camilos enfezados, uns puros camelinhos, quando o que eu quero é que de Camilo tu saias mais Rangel do que nunca e eu saia bestialmente Lobato - embora sem as brocas e lagartas para as quais o melhor veneno é justamente Camilo.

"O meu processo é anotar as boas frases, as de ouro lindo, não para roubá-las ao dono, mas para pegar o jeito de também tê-las assim, próprias. Dum de seus livros extrai sessenta frases de encher o olho. Não releio mais esse livro - não há tempo - mas releio o compendiado, o extrato, e aspiro o perfume e saboreio. Formo assim um florilégio camiliano do que nele mais me seduz as vísceras estéticas. E não discuto nem analiso, porque seria fazer gramática, do mesmo modo que não analiso botanicamente um cravo ou uma gostosa laranja mexeriqueira. Cheiro um e como a outra.

"Resumindo: meu plano é ter uma horta de frases belamente pensadas e ditas em língua diversa da língua bunda que nos rodeia e nós vamos assimilando por todos os poros da alma e do corpo. Um jardim de flores simpáticas à nossa estesia inconsciente. No meu passeio pelas Vinte horas de liteira apanhei isto: Um corujão berrou no esgalho seco de um sobro. Detive-me; fiz pouso nessa frase enchedora de olhos e ouvidos. E não anotei, por que anotada ficou para sempre em meu cérebro. Não a analiso, não a comento; ponho-a apenas em uma lapela do cérebro, como pus naquele prego um ninho de beija-flor encontrado no barranco. Se Camilo houvesse dito: Uma coruja piou no galho seco de uma árvore, eu teria deixado no barranco esse ninho de beija-flor. O 'berrou' é que me seduziu. Toda vida, para toda gente, as corujas piam - só em Camilo aparece uma que berra. Lindo!", 15

Este excerto reitera na relação entre a leitura de obras da literatura portuguesa, especificamente a obra de Camilo Castelo Branco, e a formação do estilo lobatiano. Além disso, remete ao próprio processo de criação de Monteiro Lobato, quando ele detalha, para seu destinatário, as anotações que derivam de sua leitura. A montagem de um glossário, procedimento adotado por Rangel, coloca-se em oposição ao mecanismo de "anotar as boas frases", de "anotar os jeitos". Lobato também define os objetivos dessa leitura da ficção camiliana: não significa transformar ambos, ele e o amigo, em Camilos, mas permitir que cada um evolua em seus próprios caminhos. Nesse sentido, a leitura torna-se um espaço de construção da própria identidade no universo literário, na formação do estilo, não pela cópia, e sim por meio de uma assimilação vocabular trabalhada, lição possivelmente tirada do manual de Albalat, como se viu no capítulo anterior.

\footnotetext{
${ }^{15}$ IDEM, ibidem, p. 296-7. Carta de Caçapava, 16/01/1915.
} 
Observa-se que a temática da busca do próprio estilo é retomada em diferentes cartas:

"Confundes bobamente duas coisas: clássicos e Camilo. Camilo não é
clássico no sentido gramaticoide do termo; e para afundarmos os dois no mar
do classicismo, nunca te convidaria eu, porque o aborreço sobre todas as
coisas. Convidei-te para o passeio através de Camilo como remédio contra o
estilo redondo dos jornais que somos forçados a ingerir todos os dias.
Camilo é o laxante. Faz que eliminemos a 'redondeza'. É a água limpa onde
nos lavamos dos solecismos, das frouxidões do dizer do noticiário - e
também nos lavamos da adjetivação de homens copados como Coelho Neto.
Camilo é lixivia contra todas as gafeiras. E além desse papel de potassa
cáustica, ele nos dá essa coisa linda chamada topete. Camilo nos "desabusa",
como aos seminaristas tímidos um companheiro desbocado. Ensina-nos a
liberdade de dizer fora de qualquer forma. Cada vez que mergulho em
Camilo, saio lá adiante mais eu mesmo - mais topetudo."

O mestre português encanta o pupilo pela propriedade no emprego da língua e o modo como a articula na criação de seus textos. Cada vocábulo e construção linguística é meticulosamente examinado por Lobato. E assim, que venha mais Camilo!

"Precisamos ler Camilo. Vou mandar vir um sortimento. Saber a língua é ali! Camilo é a maior fonte, o maior chafariz moderno donde a língua portuguesa brota mijadamente, saída inconscientemente, com a maior naturalidade fisiológica.

"Eu tenho a impressão de que os outros aprenderam a língua e só Camilo a teve ingênita até no sabugo da unha de todas as células do corpo." ${ }^{, 17}$

A leitura de textos camilianos liga-se ao estudo, materializado nas anotações apostas às obras, bem como ao interesse em "absorver" um estilo, no processo de construção do próprio texto. A estratégia adotada explica-se na carta de 30 de janeiro de 1915:

"O negócio de anotar Camilo só convém nas sobre-excelências; do contrário é copiá-lo inteiro. Livro há em que ele é uma roda de fogo de artifício, a chispar fagulhas do começo ao fim. Não cuidemos de quantidade, nem façamos disso tarefa. $\mathrm{O}$ meu sistema é lê-lo com atenção e marcar à margem as frases que me encantam e me aproveitam. Depois de terminada a leitura, encosto o livro: mais tarde abro-o e releio as coisas assinaladas - e copio num caderno as que ainda me impressionam." 18

Segundo Telê Ancona Lopez, “[...] o leitor/escritor materializa, ao anotar, o diálogo inerente a toda e qualquer leitura, no domínio da palavra escrita"19.

\footnotetext{
${ }^{16}$ IDEM, ibidem, p. 299. Carta da Fazenda, 23/01/1915.

${ }^{17}$ IDEM, ibidem, p. 208. Carta de Areias, 07/07/1909.

${ }^{18}$ IDEM, ibidem, p. 301. Carta da Fazenda, 30/01/1915.

${ }^{19}$ LOPEZ, Telê Ancona. “A biblioteca de Mário de Andrade: seara e celeiro da criação”. In: ZULAR, Roberto (org.) Criação em processo: ensaios de crítica genética. São Paulo: FAPESP/Iluminuras, 2002, p. 50.
} 
Infelizmente, ao pesquisar no acervo da Biblioteca Infantil e no Fundo Monteiro Lobato da Unicamp, sabe-se que não restaram exemplares de obras de Camilo Castelo Branco que tenham pertencido a Lobato.

Quando se avalia o gosto máximo de Lobato na leitura camiliana, vale a pena lembrar esta análise de Josué Montello, contemplando o mesmo Camilo:

"A opulência do vocabulário camiliano, a precipitação das frases curtas e incisivas, a combinação do arcaísmo e do neologismo, do erudito e do popular, do simples e do precioso, no rigor da construção escorreita - fazem da prosa do romancista de Eusébio Macário uma confluência dos elementos expressionais mais ricos da língua de Portugal - com as vozes de suas aldeias e de seus barcos, de seus lavradores e de seus nautas, de seus soldados e de seus bacharéis, ao mesmo tempo lírica e épica, variada e pitoresca, sentimental e ríspida, capaz dos mais ternos acalantos e dos impropérios mais causticantes." ${ }^{20}$

Entretanto, algum conhecedor das modas literárias brasileiras de 1900 talvez se pergunte: existem tantas referências à leitura de Camilo Castelo Branco e nenhuma a Eça de Queirós (1845-1900)? Para Brito Broca, Eça "não foi somente uma grande influência na literatura brasileira; foi também moda literária, que se iniciou por volta de 1878, quando se divulgou aqui $O$ primo Basílio - implantando o que os cronistas da época chamavam de 'basilismo' - até a guerra de 1914, mais ou menos.",21

Há cartas, como esta de 28 de dezembro de 1903, em que brincadeiras e comentários a respeito de personagens ecianos testemunham a frequência desse escritor português nas rodas literárias e mesmo no grupo familiar:

“Eça está muito querido cá em casa; todos o 'adoram'. A semana passada apareceu-nos um comediógrafo, José Piza, e durante três dias só lidamos com o Eça. Meu avô lê $A$ cidade e as serras, minha irmã lê $A$ ilustre casa de Ramires, eu leio suas histórias de santos - e como somos só três neste imenso casarão, não erro dizendo que a casa inteira lê o Eça." 22

Mas quando se trata de estilo literário e modelo linguístico, para Monteiro Lobato, Eça distancia-se de Camilo Castelo Branco. As críticas ao autor de O crime do Padre Amaro caminham no sentido do emprego da língua portuguesa:

\footnotetext{
${ }^{20}$ MONTELLO, Josué. "O conto brasileiro: de Machado de Assis a Monteiro Lobato". In: Caminho da fonte. $1^{\text {a }}$ ed. Rio de Janeiro: Instituto Nacional do Livro, 1959, p. 261.

${ }^{21}$ BROCA, Brito. A vida literária no Brasil - 1900. $5^{\mathrm{a}}$ ed. Rio de Janeiro: José Olympio, Academia Brasileira de Letras, 2005, p. 174.

${ }^{22}$ LOBATO, Monteiro. A barca de Gleyre. Ed. cit., p. 49. Carta de Taubaté, 28/12/1903.
} 
"Releio Os Maias. Como é grande, no sentido de volumoso! Dava dois, três livros diferentes. Acho que Os Maias seria um belo romance se fosse traduzido em português e levasse poda de foice. Há frases como esta: 'Desde moço fora célebre, na capital, por pôr casas a espanholas; a uma mesmo dera carruagem ao mês'. Acho o Eça o culpado de metade do emporcalhamento da língua no Brasil, onde o lido e o imitado é só ele, ele e mais ele. Mas Eça progrediu muito no fim. A ilustre casa de Ramires já está escrita em língua que escova os dentes. ${ }^{23}$

Se de um lado Monteiro Lobato aproxima-se até a apropriação dos textos de Camilo Castelo Branco, por outro recomenda o afastamento de Eça de Queirós, embora lhe reconheça a influência na literatura brasileira:

"Para o trabalho do estilo, a primeira empreitada é mundifica-lo, como diz você, das 'maneiras' consagradas. Fugir sobretudo da maneira do Eça, a mais perigosa de todas, porque é graciosíssima e muito fácil de imitar. 'Cigarro lânguido' - 'Caneta melancólica' - 'Tinteiro filosófico'.,"24

A comparação entre Camilo e Eça surge para mostrar o quanto o primeiro é superior no estilo e no uso da língua:

"Quanto a Camilo, vejo-o sempre o mesmo e único. E cada vez mais me dá Eça a ideia dum creme Chatilly, muito gostoso. Camilo é o rosbife quase cru, vermelho. A semana passada li dum fôlego Agulha em palheiro. Que garbo! É um romance saído de dentro dele como um rato sai dum buraco. É um jato. E sabe que anda em Portugal um vivo movimento de reação próCamilo? O câmbio do Eça cai, e como não há nenhum 'grande novo', o remédio é retroceder umas estações e parar em Camilo. Amiúdam-se os estudos camilianos. Recebi mais um de Pimentel e há dias o Jornal do Comércio trouxe colunas sobre ele.

"Eu de mim não quero outro mestre. [...]

"As ficelles do Eça também transparecem muito, e começam a enjoar quando percebemos que são ficelles. Camilo é floresta virgem, irregular, como perambeiras e espigões, com taquaruçus, bromélias, borboletas de azul celeste em voos boiados, e mamangavas tremendas, e sapos que espirram leite venenoso. Eça é um jardim francês daqueles que Le Nôtre desenhava. É possível levantar a planta dum jardim, mas quem tira a planta duma floresta virgem - dum Camilo? Eu recomendo a Boémia do espírito aos que sofrem de lazeira de estilo." 25

A presença de Camilo Castelo Branco é também testemunhada na correspondência lobatiana pela citação de uma variedade de títulos: Onde está a felicidade, Vingança, Anos de prosa, Agulha em palheiro, Amor de salvação, Vinte horas de liteira, Os brilhantes do brasileiro, A mulher fatal, Noites de insônia, O regicida, Novelas do Minho, A Caveira da

\footnotetext{
${ }^{23}$ IDEM, ibidem, p. 335. Carta da Fazenda, 07/12/1915.

${ }^{24}$ IDEM, ibidem, p. 336. Carta da Fazenda, 07/12/1915.

${ }^{25}$ IDEM, ibidem, p. 310-1. Carta da Fazenda, 30/03/1915.
} 
mártir, Eusébio Macário, Cancioneiro alegre de poetas portugueses e brasileiros, A brasileira de prazins, $O$ vinho do Porto e Boémia do espírito.

É interessante pensar que, enquanto colônia portuguesa, os primeiros modelos que recebemos foram os portugueses e, apenas posteriormente, foi se fortificando a presença cultural da França no Brasil. Lobato "retrocede" ao modelo português após sua dedicação aos autores franceses. A descoberta de um escritor que estimula o senso estético e linguístico equivale, para Monteiro Lobato, ao despertar de um leitor arguto e ávido por construir uma escrita própria. Porém, Camilo não deixa de ser muito "português de Portugal", como destaca na carta de 30 de agosto de 1909. É assim que, ao lado do discípulo apaixonado de Camilo Castelo Branco, granjeia espaço um Lobato que vê no escritor brasileiro Machado de Assis (1839-1908) o modelo de conciliação entre estilo e língua: "Estilos, estilos... Eu só conheço uma centena na literatura universal e entre nós só um, o do Machadão" 26.

\title{
Machado de Assis e os estudos da língua
}

\begin{abstract}
"Eu continuo a não achar salvação fora de Camilo, a ponto de não conseguir ler Os Maias. Já o Machado de Assis eu o alterno com Camilo. Donde concluo que em matéria de estilo há dois, Camilo lá e Machado aqui. Todos os mais cansam. Agradam muito no começo, como um pedaço de bolo inglês, mas acabam enfarando. Camilo e Machado são como o pão com manteiga - coisas de que ninguém enjoa nunca."
\end{abstract}

Monteiro Lobato ${ }^{27}$

Camilo Castelo Branco incita Lobato à busca de uma identidade no universo literário. A propriedade com a qual o luso ficcionista emprega cada vocábulo na construção de seus enredos e o estilo apurado atraem a atenção lobatiana. Entretanto, a leitura de Camilo não deixa de ser uma literatura estrangeira para Lobato. É, então, em Machado de Assis que encontra a maestria na arte de bem escrever no idioma pátrio, embora já lhe reconheça o talento desde os primeiros anos da correspondência.

Colocados ambos os escritores paralelamente em algumas cartas, Lobato alterna a exaltação:

\footnotetext{
${ }^{26}$ IDEM, ibidem, p. 92. Carta de Taubaté, 15/07/1905.

${ }^{27}$ IDEM, ibidem, p.366. Carta da Fazenda, 10/07/1916.
} 
"Não conheço melhor modelo que Machado de Assis. Camilo ainda me choca, é muito bruto, muito português de Portugal e nós somos daqui. Machado de Assis é o clássico moderno mais perfeito e artista que possamos conceber. Que propriedade! Que simplicidade! Simplicidade não de simplório, mas do maior dos sabidões. Ele gasta as suas palavras como um nobre de raça fina gasta a sua fortuna e jamais como o parvenu, o upstart, que começou vendeiro de esquina e acabou comprando um título de barão do papa." 28

Para ele, Machado alia a língua e o estilo na escrita literária, sem deixar de ser atual para a época de Lobato:

“[...]Machado de Assis é o mais perfeito modelo de conciliação estilística; seu classicismo transparece de leve e nunca ofende os nossos narizes modernos. Como vivemos neste século e neste continente, não podemos, sem uma hábil e manhosa tática, usar expressões lusitanas e de tempos já muito remotos." 29

Nesse sentido, Aurélio Buarque de Holanda, em "Linguagem e estilo de Machado de Assis", ilumina o aspecto linguístico na ficção machadiana:

"Espanada de algumas grossas teias de aranha do falar lusitano, a sua sintaxe apresenta-se, de ordinário, mais leve, como que mais transparente; mas o disfarce não é tão perfeito que por trás das cortinas não estejamos a ver agindo a mão de Frei Luís de Sousa, Manuel Bernardes ou Castilho Antônio.

"O que ele teve foi o segredo de conciliar - e nem sempre - as exigências da sintaxe de além-mar com a mais corrente entre nós, sem nunca transgredir, porém, com os seus princípios de cultor extremado do idioma. E o que lhe transmite à prosa, e não raro ao verso, aquele amável tom de simplicidade e harmonia, não será tanto o efeito dessa conciliação como as suas qualidades intrínsecas de escritor, o feitio harmonioso e simples do seu espírito, a revelar-se em tudo que lhe saiu da pena." ${ }^{30}$

Em 1904, segundo ano da troca epistolar com Godofredo Rangel, menções ao Bruxo do Cosme Velho evidenciam a presença do escritor já no tempo do estudante Monteiro Lobato. Estão citados ao longo dessa correspondência: Iaiá Garcia, Helena, Memórias póstumas de Brás Cubas, Histórias sem data, Casa velha, Quincas Borba, Dom Casmurro, Esaú e Jacó e Memorial de Aires. A carta de 3 de junho de 1915 remete à leitura:

"Ontem li Historias sem data, de Machado, e ainda estou sob a impressão. Não pode haver língua mais pura, água mais bem filtrada, nem melhor cristalino a defluir em fio da fonte. E ninguém maneja melhor tudo

\footnotetext{
${ }^{28}$ IDEM, ibidem, p. 216. Carta de Areias, 30/08/1909.

${ }^{29}$ IDEM, ibidem, p. 212. Carta de Areias, 14/08/1909.

${ }^{30}$ FERREIRA, Aurélio Buarque de Holanda. "Linguagem e estilo de Machado de Assis". In: Linguagem e estilo de Machado de Assis, Eça de Queirós e Simões Lopes Neto. Rio de Janeiro: Academia Brasileira de Letras, 2007 , p.4. Disponível em: http://www.academia.org.br/abl_e4w/media/Linguagem\%20e\%20Estilo\%20de\%20Machado-Eca-Simoes\%20\%20INTERNET-final.pdf. Acesso em 10 jun. 2012.
} 
quanto é cambiante. A gama inteira dos semitons da alma humana. É grande, é imenso, o Machado. É o pico solitário das nossas letras. Os demais nem lhe dão pela cintura." 31

A relação com Machado de Assis é reiterada em 1939, por ocasião do centenário do autor, quando La Prensa, jornal de Buenos Aires, encomenda a Lobato um artigo. No texto, que lembra muito as referências n'A barca de Gleyre, a lição do mestre é destacada:

"Machado de Assis ensinou o Brasil a escrever com limpeza, tato, finura, limpidez. Criou o estilo lavado de todas as douradas pulgas do gongorismo, do exagero, da adjetivação tropical, do derramado, da enxúndia, da folharada intensa que esconde o tronco e o engalhamento da árvore. [...]

"Ensinou-nos a escrever tão bem, dando-nos uma série de obras tão perfeitas de equilíbrio e justa medida, que 'abafou a banca', como diria um meu amigo analfabeto, impenitente jogador de roleta. E não só a abafou no Brasil, como ainda em Portugal. Nem o próprio Eça de Queirós, o talento mais rico em arte que Portugal produziu, chega à perfeição de Machado. Em Eça há 'elegâncias', maneirismos, atitudes - deliciosas atitudes, mas que o impediram de plantar nas regiões sereníssimas do estilo de Machado de Assis." ${ }^{32}$

Geovana Gentili Santos investiga essa relação no artigo "O papel de Machado de Assis na formação literária de Monteiro Lobato", atribuindo às leituras machadianas o emprego de uma linguagem mais límpida e objetiva na obra infantil lobatiana. Esse ponto, segundo a autora, pode ser verificado na própria renovação do tratamento linguístico conferido aos livros para crianças, na maior acessibilidade dada aos clássicos pelo modo de narrar de D. Benta e pelo repúdio da turma do Sítio à linguagem mais complicada. Destarte,

"Por meio do contato com as obras machadianas, Lobato assimila que a riqueza de uma obra literária não consiste no seu rebuscamento linguístico; ao contrário, a opção por uma linguagem precisa, sem "enfeites literários", propicia a aproximação da obra com o leitor, ampliando seu alcance." 33

Para Josué Montello, a relação entre Monteiro Lobato, Camilo Castelo Branco e Machado de Assis pode ser estabelecida desta forma:

"Não obstante essa preferência da maturidade, facilmente se constata que Lobato, no curso de toda a sua vida literária, sempre ficou mais perto de Camilo que de Machado de Assis, por um imperativo de sua feição inconformada e polêmica.

"E é mais no estilo do que na técnica da composição que está a chave do conto de Monteiro Lobato. Daí também a circunstância de que o mais

\footnotetext{
${ }^{31}$ LOBATO, Monteiro. A barca de Gleyre. Ed. cit., p. 316. Carta da Fazenda, 03/06/1915.

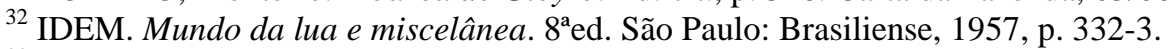

33 SANTOS, Geovana Gentili. O papel de Machado de Assis na formação literária de Monteiro Lobato. Miscelânea, Assis, v. 6, jul./nov. 2009. Disponível em:

<http://www.assis.unesp.br/posgraduacao/letras/mis/pdf/v6/geovana.pdf>. Acesso em: 20 nov. 2011.
} 
popular dos tipos desse mestre da novela curta não sai de um conto, sim de uma página polêmica.

"A vivacidade da frase, na qual a palavra exata, por vezes de sabor clássico, parece cair perpendicularmente no texto vibrátil; o risco nítido da deformação caricatural; a onipresença do escritor no desenvolvimento da explanação ou da narrativa - deixam transparecer no criador do Jeca Tatu as afinidades camilianas." 34

Fato é que tanto Machado como Camilo provocam em Monteiro Lobato um especial interesse pela língua portuguesa, fazendo-o avançar em seus estudos linguísticos. Em 30 de setembro de 1915, ele agradece ao amigo Rangel as correções feitas a um texto seu (não identificado na carta), reunindo também aspectos dessa sua trajetória em busca da tão procurada língua de Frei Luís de Sousa:

"Grande bem me fazes com a denúncia das ingramaticalidades. De gramática guardo a memória dos maus meses que em menino passei decorando, sem nada entender, os esoterismos do Augusto Freire da Silva ${ }^{35}$. Ficou-me da 'bomba' que levei, e da papagueação, uma revolta surda contra gramática e gramáticos; e uma certeza: a gramatica fará letrudos, não faz escritores. Depois, quando cheguei à puberdade estética e sobrevieram as curiosidades mentais, pus-me a ler - mas só em francês e isso até depois dos 25 anos. Até essa idade conto nos dedos os livros em nossa língua que li: um pouco de Eça, uns cinco volumes de Camilo, meio Machado de Assis. E Euclides e jornais. Como vês, ensarnei-me a fundo na sarna gálica. A reação vem dos tempos da 'Velha Praga'. Ali ainda sou o antigo. Em 'Urupês' aparecem uns clarões ricocheteados de Camilo - o grande Camilo que me revelou a língua portuguesa e me fez ver as balisas que a extremam da língua bunda dos jornais e deputados - a Língua de Cafra para Cafrarias, diz Camilo. De 'Urupês' em diante tateio, na luta das transições, procurando saltar para o outro lado. [...] entreguei-me a aprender, em vez de gramatica, língua - lendo os que a têm e ouvindo os que falam expressivamente." ${ }^{36}$

Este percurso narrado ao amigo foi assim resumido por Regina Helena Pires de Brito: o período de alheamento com relação ao estudo da língua portuguesa; a introdução da literatura portuguesa às suas leituras estrangeiras e uma preocupação extrema com o estudo da língua via literatura ${ }^{37}$. Monteiro Lobato também estabelece uma distinção entre "aprender gramática" e "aprender a língua", repudiando aquele e utilizando-se da leitura para alcançar este. Recorre a Camilo Castelo Branco e a Machado de Assis, reconhecendo no ficcionista brasileiro a conciliação entre língua e estilo.

\footnotetext{
${ }^{34}$ MONTELLO, Josué. "O conto brasileiro: de Machado de Assis a Monteiro Lobato". In: Caminho da fonte. Ed. cit., p. 262.

${ }^{35}$ Monteiro Lobato foi reprovado no primeiro exame que fez - o de português. Nota da edição de 1948.

${ }^{36}$ LOBATO, Monteiro. A barca de Gleyre. Ed. cit., p. 329-30. Carta da Fazenda, 30/09/1915.

${ }^{37}$ BRITO, Regina Helena Pires de. A Influência de autores estrangeiros em Lobato e a constituição da Brasilina. Revista do GELNE. v. 4, n. 2, [S.1], 2002. Disponível em:〈http://www.gelne.ufc.br/revista_ano4_no2_21.pdf〉. Acesso em: 11 ago. 2010.
} 


\section{Um passeio pelo país dos vocábulos}

Durante esse período de leituras e estudos em que Lobato atenta para o uso da língua portuguesa nos escritores já referidos, o desejo de melhorar o vocabulário o impulsiona a ler dicionários. Referência editorial para a época, o Dicionário contemporâneo da língua portuguesa (1881), mais conhecido no Brasil como Dicionário Caldas Aulete, iniciado por Francisco Júlio de Caldas Aulete (1826-1878), é leitura à qual muito se dedica, como mostra a carta de 7 de julho de 1909:

"Mandei vir o dicionário de Aulete, que ainda é o melhor, e estou a lê-lo. Aventura esplêndida, Rangel! Os vocábulos são velhos amigos nossos que pelo fato de diariamente nos acotovelarem no brouhaha da Língua, não nos merecem a atenção curiosa e indagadora que damos às palavras estrangeiras. Pelo fato de frequentar um parente, você chega a ponto de não poder descrever-lhe a cara - e no entanto é capaz até de desenhar de memória a cara dum estranho que viu ontem. Deixam de nos impressionar as coisas habituais. Daí o valor da leitura de dicionário. Todo o povo tumultuoso da praça pública da Língua lá o encontramos individualizado, como soldados em quartel, cada um com o seu número, o seu posto, perfilados e obedientes quando os defrontamos."

Esmiuçar os significados das palavras caracteriza o foco de estudo proposto por Lobato. Nesse trecho da carta, o remetente direciona seu olhar para a riqueza lexical, consciência esta que, anos mais tarde, marcaria a escrita de Guimarães Rosa. A leitura do dicionário atrai a atenção lobatiana para a polissemia:

"Na rua vemos passar cavalos. No dicionário encontramos um CAVALO. 'Quem é você?' E ele muito sério: '... substantivo masculino. Quadrúpede doméstico, solípede; ramo ou tronco em que se enxerta; banco de tanoeiro etc. etc.'. A gente regala-se com o mundo de coisas que cavalo é, e muitas vezes também nos regalamos com as cavalidades do dicionarista. Se o cavalo é um 'quadrúpede doméstico', como se arranja o dicionarista para denominar um equus selvagem? E vamos assim mentalmente retificando aqui e ali o dicionário, enquanto ele nos faz o mesmo aos inúmeros pontos vocabulares em que claudicávamos sem o saber. Quantos novos sentidos de palavras, das quais sabíamos um só? Quanta construção bonita de frase, com forma intransitiva de verbos habitualmente transitivos? E as antigualhas merecedoras de restauração? Que deleite seguir em mente a evolução dum vocábulo! Ver, por exemplo, agora sair de hac hora, como a borboleta sai da crisálida; e preto sair de pyraites (queimado), como sai preto o papel branco depois que o fogo o queima. E caravançará sair do persa Karvan sarai. Essa leitura nos vai dando firmeza, com o conhecimento da exata propriedade dos vocábulos." ${ }^{39}$

\footnotetext{
${ }^{38}$ LOBATO, Monteiro. A barca de Gleyre. Ed. cit., p. 206-7. Carta de Areias, 07/07/1909.

${ }^{39}$ IDEM, ibidem, p. 207. Carta de Areias, 07/07/1909.
} 
É com este afinco que Lobato chega mesmo a propor a Rangel um exercício formador das respectivas expressões:

"Estou lendo e marcando as palavras úteis para o meu caso, os sentidos figurados, aproveitáveis nesta 'nossa' literatura etc. Ainda estou no 'A' e já tenho belos achados. É um verdadeiro mariscar de peineiras. Deves fazer a mesma coisa, e depois trocamos as notas." 40

Embora tenha se aportado apenas no ano de 1909 neste "passeio no país dos vocábulos", modo como Lobato se refere, na carta de 30 de agosto, ao estudo empreendido, outro benefício trazido pela leitura do dicionário é a retificação de algumas pronúncias às quais Lobato apelida de "batatas" vocabulares:

"Parei com os contos e segui com o Aulete. Dá-me mais prazer isto, além
das vantagens que traz - prazer pitoresco, variado como o de um general que
assistisse ao desfile de 70 mil homens não uniformizados, cada um vestido
dum jeito e lá com sua cara diferente. Outra vantagem está sendo a
retificação de muitas palavras que eu pensava que eram uma coisa e são
outra; e também já cavei 24 vocábulos que eu pronunciava erradamente. São
24 'batatas' de que fico liberto. Estou no M."

Observador da propriedade vocabular, Monteiro Lobato atém-se à questão da construção de significados nas frases e para isso empreende estudo por meio das leituras de Camilo Castelo Branco e de Machado de Assis.

É nessa mesma época que o escritor Euclides da Cunha (1866-1909) figura em cartas d'A barca de Gleyre. Cabe dizer que a quantidade de menções é bem menor se comparadas com as citações de Camilo e Machado, mas o modo de análise dos textos euclidianos, principalmente no que se refere aos usos linguísticos, revela mais algumas características da faceta leitora de Monteiro Lobato.

Para o autor de Ideias de Jeca Tatu, Euclides da Cunha era um conhecedor das palavras e sabia bem como as empregar, fato este que o diferenciava na esfera jornalística:

"Euclides da Cunha foi um grande ledor de léxicos. Nos Sertões eu notei como ele fugia à vulgaridade sem cair no abstruso, por meio do emprego de palavras que o jornalismo não estafou (porque a cachamorra que achata todas as palavras da língua é sempre o jornalismo). Em vez de prematuro, imaturo. Implexo por complexo etc. Uma variação dos prefixos habituais da imprensa - e a frase fica mais fina, toda petulante de distinção. A desgraça em tudo é a vulgaridade - o 'toda gente'." 42 .

\footnotetext{
${ }^{40}$ IDEM, ibidem, p. 207. Carta de Areias, 07/07/1909.

${ }^{41}$ IDEM, ibidem, p. 215. Carta de Areias, 30/08/1909.

${ }^{42}$ IDEM, ibidem, p. 207. Carta de Areias, 07/07/1909.
} 
A habilidade de fugir ao lugar comum e diferenciar-se dos demais coloca nosso escritor frente aos textos de Euclides da Cunha. Em carta de 11 de setembro de 1911, captada uma série de situações referentes ao uso de adjetivos, verbos e advérbios, Lobato analisa detalhadamente o estilo euclidiano ao mesmo tempo em que o compara com a escrita jornalística:

"Volto ao Euclides. Estive a lê-lo e pareceu-me que a sóbria e vigorosa beleza do seu estilo vem de não estar cancerado de nenhum dos cancros do estilo de toda gente - estilo que o jornalismo apurou até ao ponto-de-bala acadêmico, tornando-o untuoso, arredondado e impessoal." ${ }^{43}$

A linguagem deve ser límpida, direta. O adjetivo deve ser posposto ao substantivo, levando em conta que a expressão ganha com os vocábulos nessa ordem; facilita-se a compreensão do sentido das palavras e a consequente aproximação da língua portuguesa corrente no Brasil:

“1) Euclides evita prepor o adjetivo ao substantivo, o que contraria a lógica percepção cerebral. Por exemplo: 'exaustivas correrias', 'paupérrimas choupanas', 'esguia palmeira'. O que na mecânica da leitura o cérebro tem de representar ao receber a impressão dum desses adjetivos (sem ter ainda recebido a impressão do substantivo posposto), é uma qualidade vaga $e$ dissipada em extremo, capaz de mil articulações diversas: ao passo que na forma contraria - 'palmeira esguia', por exemplo - a impressão é de extrema nitidez e vigor; o cérebro representa a coisa indicada pelo substantivo e imediatamente a qualifica ou determina com o adjetivo posposto. Ora, em Euclides não há adjetivos prepostos aos substantivos, ao passo que no estilo de jornal é esta a forma que predomina ('nosso inteligente colaborador', 'o distinto amigo', a 'gentil senhorita', a 'virtuosa consorte', o 'honrado comerciante desta praça', etc.)." ${ }^{, 4}$

Na colocação dos verbos e advérbios, advoga o emprego de uma linguagem que exploda em seu significado, aproveitado ao máximo o valor de cada palavra:

“2) Os verbos em forma composta, essa nojenta coisa de agregar o 'ter' e o 'haver' ao resto da verbalhada. É outro vício dessorante, que enfraquece o estilo com amortecer a nitidez da impressão cerebral ('haviam feito', 'tinham estado comendo', etc.). As formas verbais simples são esplêndidas de energia e Euclides só emprega as compostas quando indispensáveis. Já o estilo de jornal só quer saber das compostas, justamente porque melifluem a frase, fá-las de salão de Clube Recreativo. Abro um Minarete e encontro: 'andaram percorrendo', 'tiveram começo', 'estavam reclamando', 'foram verificados', etc. A explicação do fato é a mesma do adjetivo preposto dispersão, dissipação.

“3) Os advérbios em mente, outra asquerosa invenção do jornal com o fito de adocicar o estilo por causa das leitoras folhetinistas, normalistas,

\footnotetext{
${ }^{43}$ IDEM, ibidem, p. 252. Carta de Taubaté, 11/09/1911.

${ }^{44}$ IDEM, ibidem, p. 252-3. Carta de Taubaté, 11/09/1911.
} 
pianistas, feministas - todo o hospital dos cloróticos para os quais o jornal é um pão de cada dia - pão doce. A razão ainda é a mesma. Claro que têm mais força as formas - 'de leve', 'à larga', 'à sós' - do que o 'levemente', o 'largamente', e o 'solitariamente'. Euclides é idiossincrásico aos advérbios em mente e o estilo de jornal não quer outra coisa. Pela-se por eles." ${ }^{, 45}$

Depois das considerações sobre essa utilização que seria ideal da língua portuguesa, Lobato exemplifica com um excerto de Os sertões, de Euclides da Cunha, e brinca com seu destinatário reescrevendo o mesmo trecho na linguagem jornalística:

"Veja este trecho: 'A deiscência das vagens das catingueiras, abrindo-se com estalidos secos e fortes, soava-lhes como percussões de gatilho ou estalo de espoletas, dando a ilusão de descargas súbitas de alguma algara noturna inopinada e as grinaldas fosforescentes dos cananãs fulguravam ao longe, esbatidas nas sombras, como restos de fogueiras quase apagadas, em torno das quais velassem, em silêncio, expectantes tocaias numerosas...' E compare como ficaria em jornalismo: 'A deiscência das vagens das catingueiras, abrindo-se com secos e fortes estalidos, soava-lhe como agudas percussões de gatilho e secos estalidos de espoleta, dando a ilusão de súbitas descargas e alguma inopinada algara noturna, e as fosforescentes grinaldas dos cananãs fulguravam remotamente, esbatidas nas sombras, como restos de fogueiras quase apagadas, em torno ás quais estivessem velando, silenciosa e expectantemente, numerosas tocais, etc'. ",46

Para concluir, essa trajetória de Monteiro Lobato pelo reino das palavras via literatura marca uma fase do escritor na busca de seu próprio estilo literário. Em dezembro de 1917, ele confessa que em todas as literaturas segue em busca do carnívoro e evita farinhas, isto é, autores como Camilo Castelo Branco, Machado de Assis e Euclides da Cunha agradam-lhe pelo estilo direto e enxuto: "Camilo é o estilo estadulho. Dá porradas geniais!"; "Machado de Assis é capilé refinado, filtrado, puríssimo, bebido pela taça da cicuta de Sócrates"; "Euclides também não é [capilé] - mas se o fosse, seria capilé com geodesia" ${ }^{47}$. É com leituras, estudos e anotações que ele exercita o fazer literário.

Mas quanto tempo leva para que um escritor encontre seu próprio estilo? Para o Lobato de 1917: "Meu estilo está em formação. Talvez fique em formação toda a vida. O de hoje é uma fase. Fase da Lua Cheia, talvez precursora de mais equilibrada e discreta Minguante" ${ }^{48}$.

\footnotetext{
${ }^{45}$ IDEM, ibidem, p. 253. Carta de Taubaté, 11/09/1911.

${ }^{46}$ IDEM, ibidem, p. 253-4. Carta de Taubaté, 11/09/1911.

${ }^{47}$ IDEM, ibidem, p. 414. Carta de São Paulo, 11/12/1917.

${ }^{48}$ IDEM, ibidem, p. 414. Carta de São Paulo, 11/12/1917.
} 


\title{
Capítulo 3
}

\section{Ler ou não ler os brasileiros, eis a questão!}

\begin{abstract}
"Se há quem escreva nos outros países é que existem por lá compensações sérias, renome e dinheiro. Desde que entre nós não aparece compensação nenhuma, escrever não passa de pura manifestação de cretinice."
\end{abstract}

Monteiro Lobato ${ }^{1}$

Quando se fala em rastrear um possível percurso de leituras empreendidas por Monteiro Lobato, espera-se logo uma lista na qual constem vários títulos nacionais. Verificase que o contato com a literatura brasileira foi intensificando-se à medida em que nosso escritor deixou de se dedicar aos clássicos franceses e, posteriormente, aos portugueses.

É neste sentido ainda que Tadeu Chiarelli afirma que Lobato parecia comportar-se como um exilado dentro do país, com sua visão preconceituosa do Brasil, do ambiente cultural local e da produção literária e artística. É claro que esta seria apenas uma das bases do nacionalismo lobatiano, em sua primeira fase. Ademais, como será abordada ao longo deste capítulo, a aproximação ao grupo de intelectuais do jornal $O$ Estado de S. Paulo contribuiu para que ele se interessasse mais efetivamente pela realidade, literatura e arte brasileira. ${ }^{2}$

A leitura do conjunto de cartas d'A barca de Gleyre revela que há comentários críticos acerca de escritores e obras nacionais, mas não chegam a ser um número tão expressivo se comparados àqueles sobre outras literaturas.

Embora se acentuem com o passar do tempo, referências a autores brasileiros são feitas n'A barca desde o primeiro ano de carteio com Godofredo Rangel. Aliás, o bilhete que abre o livro dialoga com os versos de Olavo Bilac (1865-1918). É a partir da leitura do romance Tartarin de Tarascon, de Daudet, que Ricardo Gonçalves, companheiro de Rangel e Lobato, apelida o chalezinho onde moravam de Minarete e os moradores de muezins, brincadeira esta presente no primeiro bilhete:

\footnotetext{
${ }^{1}$ LOBATO, Monteiro. A barca de Gleyre. Ed. cit., p. 315. Carta da Fazenda, 17/05/1915.

${ }^{2}$ Além de analisar os diferentes momentos da relação de Lobato com o Brasil, Tadeu Chiarelli acredita que um dos fatores dessa situação de exílio (auto-exílio) acaba sendo a própria formação de Lobato, centrada em autores europeus. Cf. CHIARELLI, Tadeu. "Lobato antes de Lobato". In: Um jeca nos vernissages. São Paulo: EDUSP, 1995, p. 107-141.
} 


\title{
"Primeira visita de Lobato a Rangel
}

“(Bilhete deixado no Minarete para Ricardo e Rangel, os dois muezins iniciais)

\author{
"TÉ, MUEZINS!
}

"Asas da saudade abertas ao vento! Por elas arrastado transporte-me hoje - sábado - ao Minarete fecundo.

"Estava deserto. No ar parado moscam zumbiam. Moscas zumbiam no ar parado... Tristeza. Desolação. Sobre a mesa dormiam um Flaubert e um Coelho Neto. Não os despertei. Mas dum companheiro de soneca, Bruno de Cádiz $^{3}$, furtei alguns sonetos desconhecidos. Era o Álbum do Minarete e nele revi a cena inicial dos Domingos Boêmios, e nele encontrei recordada a 'memorável farpela cor de pinhão do Lobato'.

"Boa farpela! A mais espetacular que ainda possui. Alfaiataria Galo. Mereces na verdade mais que uma simples menção - mereces biografia, ó veneranda companheira de 'vecchia zimarra', da famosa capa de borracha do $\mathrm{Lino}^{4}$ e da 'fatiota verde do Tito". Se algum dia me acudir engenho e arte, juro-te, farpela cor de pinhão, que te narrarei a mocidade, a maturidade e a melancólica velhice.

"Havia ainda sobre a mesa... Céus!... Que prodigioso acontecimento! Que jamais prevista prodigalidade! Havia tinta!...

"Silêncio. No ar parado não canta o sino. Só voejos de moscas e o leve sussurro do vento na folhagem da paineira. As folhas do coqueiro aflam ao vento. Silêncio... Súbito, um apito distante corta o espaço e, triste e melancólico, vem ferir-me o ouvido. É a Central... E em meu coração brotam pungentes saudades da minha infância em Taubaté. Ó infância minha na roça, quanta poesia, etc. etc. Adeus, vou-me embora, vou-me levado para outras terras. As recordações angustiam-me, etc. etc. Adeus, muezins ausentes, que deixam as portas abertas. E se eu fosse um ladrão?

"Em resumo: o Lobato veio visitá-los e perdeu o latim. Volta amanhã. Deixa Lendas e narrativas e Robert Helmont. Está de férias por todo um mês. Adeus. Té, Bezuquet! Vé, Tartarin!"6

Em nota da edição de 1948 d'A barca de Gleyre, Lobato conta que há no bilhete uma imitação/ paródia do estilo em falsete de "no ar parado um sino canta", sem identificar o título do poema de onde saíra o verso. A brincadeira com os versos de Bilac em "Surdina" mostra como as leituras integravam o repertório do missivista e era conhecimento partilhado entre os

\footnotetext{
${ }^{3}$ Pseudônimo de Ricardo Gonçalves.

${ }^{4}$ Lino Moreira, companheiro no grupo Cenáculo.

${ }^{5}$ Tito Lívio Brasil, companheiro no grupo Cenáculo.

${ }^{6}$ LOBATO, Monteiro. A barca de Gleyre. Ed. cit., p. 33-37. Bilhete deixado por Lobato, 1903 (sem data completa).
} 
destinatários Godofredo Rangel e Ricardo Gonçalves. É interessante se transcrever o poema para melhor compreender a paródia:

\section{Surdina ${ }^{7}$}

No ar sossegado um sino canta, Um sino canta no ar sombrio... Pálida, Vênus se levanta...

Que frio!

Um sino canta. O campanário Longe, entre névoas, aparece... Sino, que cantas solitário, Que quer dizer a tua prece?

Que frio! embuçam-se as colinas; Chora, correndo, a água do rio; E o céu se cobre de neblinas... Que frio!

Ninguém... A estrada, ampla e silente, Sem caminhantes, adormece...

Sino, que cantas docemente

Que quer dizer a tua prece?

Que medo pânico me aperta O coração triste e vazio!

Que esperas mais, alma deserta?

Que frio!

Já tanto amei! já sofri tanto!

Olhos, por que inda estais molhados?

Por que é que choro, a ouvir-te o canto,

Sino que dobras a finados?

Trevas, caí! que o dia é morto! Morre também, sonho erradio! A morte é o último conforto... Que frio!

Pobres amores, sem destino, Soltos ao vento, e dizimados! Inda vos choro... E, como um sino, Meu coração dobra a finados.

E com que mágoa o sino canta, No ar sossegado, no ar sombrio! Pálida, Vênus se levanta...

Que frio!

\footnotetext{
${ }^{7}$ BILAC, Olavo. "Surdina". In: Antologia: Poesias. São Paulo: Martin Claret, 2002. Alma Inquieta. (Coleção a obra-prima de cada autor). Disponível em: http://www.dominiopublico.gov.br/download/texto/bv000285.pdf. Acesso em: 17 jul. 2013.
} 
Olavo Bilac, parodiado nesse início da correspondência, é citado em outras cartas d'A barca, entretanto, em nenhuma delas Lobato se detém especificamente na discussão de aspectos da produção literária do poeta parnasiano. No Fundo Monteiro Lobato CEDAE/IEL/UNICAMP foi localizado o exemplar de Poesias, de Olavo Bilac, que contém Panoplias, Via láctea, Sarça de fogo, Alma inquieta, As viagens, O caçador de esmeraldas, Profissão de fé ${ }^{8}$. A dedicatória - "Ao Bello espirito de Adalgiso Pereira, affectuosamente, Olavo Bilac. S. Paulo, 1915.” - revela que o livro, na verdade, pertencera ao conceituado professor mineiro Adalgiso Pereira. A prática de emprestar ou pegar obras emprestadas era hábito de Lobato, como se observa em diversas cartas.

Coelho Neto (1864-1934), cujo livro se encontra sobre a mesa dos amigos residentes no Minarete, anos depois manterá relações epistolares com Lobato. Aqui, vale apenas mencionar que o ficcionista maranhense e Bilac são os dois únicos escritores brasileiros citados nas cartas de 1903.

Em 1904, ampliam-se as menções à literatura nacional, embora ainda sejam poucas se confrontadas com aquelas à literatura estrangeira. Graça Aranha (1868-1931) é o primeiro escritor brasileiro a ter obra comentada. Na carta de 4 de janeiro de 1904, Lobato, ainda estudante no Largo São Francisco, escreve a Rangel sobre o romance Canaã e já revela sensibilidade crítica apurada frente ao texto literário:

“[...] Canaã é o que chamam uma 'obra forte', e 'obra forte' quer dizer 'obra fraca'. Não é paradoxo. As 'obras fracas' no presente são as incompreendidas, ou de compreensão só possível no futuro. E as fortes são as que de tal modo satisfazem às exigências do presente que provocam estouros de entusiasmo - obras despóticas. Mas passam com a passagem dessas exigências. Acho a tese de Canã̃ muito atual: imigração, colonização, absorção etc. Quando tudo mudar, daqui a cem anos, quem vai interessar-se pelas ideias de Milkau e Lentz? Quem hoje lê os romances sobre a escravidão? Os argumentos da Cabana do Pai Tomás nos fazem sorrir - e eram tão fortes no tempo que deflagraram uma guerra. Os romances de Madame de Staël nos dão ideia de anquinhas, saia balão. Canã̃ será um grande livro enquanto perdurarem os nossos problemas imigratórios; depois irá morrendo - e os futuros leitores pularão os pedaços de Lentz e Milkau. Já o Brás Cubas é eterno pois enquanto o mundo for mundo haverá Virgílias e Brases; mas Milkau é um metafísico de hoje, tem ideias de hoje e filosofa hojemente; amanhã só será lido pelos futuros Melos Morais."

8 IDEM. Poesias. $4^{\text {a }}$ ed. Rio de Janeiro: Livraria Francisco Alves, 1906. Localização no acervo CEDAE/IEL/UNICAMP: código MLb 800045.

${ }^{9}$ LOBATO, Monteiro. A barca de Gleyre. Ed. cit., p. 51-2. Carta de Taubaté, 04/01/1904. 
Apresentada essa argumentação, nota-se que, neste início de século XX, Lobato já levantava questões que de certo modo estariam em Italo Calvino em Por que ler os clássicos; entre elas, a da permanência de determinadas obras ao longo dos séculos. Fazer comparações é uma característica das análises lobatianas, observada em outros capítulos deste trabalho. Para isso, o escritor vale-se de seu repertório de leituras que abrange obras e escritores de diferentes épocas e nacionalidades. No trecho da carta estão, no passado, Harriet Beecher Stowe, Madame de Staël e Machado de Assis, este sempre alvo de julgamentos favoráveis e sobressaindo-se aos demais.

Em carta de 20 de janeiro, também de 1904, o jovem leitor retoma sua análise e confronta a descrição da paisagem em Graça Aranha com as soluções de Chateaubriand, e a valoriza na comparação com a pintura brasileira de seu contemporâneo, Antônio Parreiras. E vai mais longe em sua análise, evoca Goethe, Nietzsche e Zola, mas não traz à tona autores brasileiros:

"Queres mais impressões sobre Canaã (note que não digo 'minha humilde opinião', 'meu fraco parecer'. Para quê?). Li Canaã num exemplar do Cândido ${ }^{10}$, faz tempo, e achei um livro forte, sadio, certo - e com excelentes paisagens. Na pintura de cenas Graça Aranha é criador. Tudo vive. [...] Suas descrições de florestas fazem-me sentir um mormaço e um cheiro de folhas e musgos molhados. Não é mais a mata descrita pelas receitas de Chateaubriand. É mata, mato de verdade. Os escuros dos verdes, os úmidos, os fofos, a calma dos troncos, a paciência de tudo, a paulama, a cipoeira, os farfalhos - todo o 'jogo de futebol parado' da botânica. Equivale a Antônio Parreiras - o nosso único pintor que pinta matas certas.[...]

"O livro conduz duas coisas paralelas, uma realista, outra simbólica. Milkau e Lentz são dois revenants do tempo de Byron vestidos à moderna, que passam pelo romance como nuvens, filosofando ao modo de Goethe no Wilhelm Meister, defendendo ideias polares - mas ligados pela mesma superioridade mental; Milkau simboliza a boa Alemanha contemplativa e musical, e Lentz simboliza a Alemanha perigosa que eu tenho medo surja de Nietzsche. São os Froments dos 'Evangelhos' de Zola. Embaixo desse nevoeiro de filosofia, a boiar mansamente por toda a obra, vemos a vida brasileira sem nenhuma deformação patriótica, com todas as suas chinfrinices - e personagens apequenados pelo contraste com a violentíssima natureza tropica. $[\ldots]$

"Graça Aranha é um artista e um sociólogo; este passará mas aquele fica; os sociólogos lidam com problemas passageiros; só os artistas lidam com coisas eternas." $" 11$

\footnotetext{
${ }^{10}$ Cândido Negreiros, companheiro no grupo Cenáculo.

${ }^{11}$ LOBATO, Monteiro. A barca de Gleyre. Ed. cit., p. 56-7. Carta de Taubaté, 20/01/1904.
} 
Enquanto Antônio Parreira escolhe suas tintas para dar vida à sua pintura, Graça Aranha seleciona bem as palavras na composição das cenas do romance dele. Tadeu Chiarelli nos alerta para essa importante característica de Lobato: realizar comparações entre literatura e artes plásticas, sob uma ótica impregnada de naturalismo, numa filiação crítica a Émile Zola $^{12}$.

Se por um lado há aqueles que merecem a atenção e agradam, não se pode negar a existência de autores menos admirados por Lobato: "O Goulart é o meu Montaigne - o livro de cabeceira. Ali aprendo como não se deve escrever." "13 Artur Goulart Penteado (1872-1910) é um dos "detestados literatos do Brás", conforme nota de 1948 em A barca de Gleyre. Característico do estilo lobatiano, humor e ironia predominam em suas observações críticas. Quando Rangel reclama dos olhos cansados, Lobato lhe sugere: "Eu, se fosse médico de olhos, receitava Artur Goulart para a cura da mania de ler à noite." 14

Contudo, nem sempre se consegue determinar quem recebe as críticas. Vale lembrar que A barca de Gleyre, lançada em 1944, foi editada pelo próprio Lobato, assunto já abordado na introdução desta dissertação. Fato é que alguns autores tiveram o nome modificado, como é o caso de Macuco, personalidade desconhecida, inclusive no índice onomástico organizado por Vladimir Sacchetta, na edição de 2010 da Globo.

O que se sabe é que constam vinte cartas d'A barca com referências ao incógnito escritor, um dos "literatos do Brás" assim como Artur Goulart. Através dos comentários, entende-se que os participantes do Cenáculo soubessem a quem Lobato se referia como Macuco, hipótese esta que pode inclusive se estender a outros amigos e pessoas do círculo social da época. Macuco pode ter sido apenas uma figura criada, alegoria do estilo rebuscado, da inconveniência em termos de literatura. Verificam-se principalmente alusões do tipo "Macuco diria isso assim..." ou "Se fosse o Macuco...", como nesta carta de 20 de janeiro de 1904: “[...] O adjetivo de que o Macuco mais gosta deve ser o 'nítido’, e não há cretino que ao dar opinião sobre qualquer pintura (a Gioconda ou um Corot) não venha com o clássico: ‘Como está nítida!' Pois foi isso. O naturalismo morreu no nítido fotográfico.” 15

\footnotetext{
${ }^{12}$ CHIARELLI, Tadeu. Op. cit., p. 118.

${ }^{13}$ LOBATO, Monteiro. A barca de Gleyre. Ed. cit., p. 55. Carta de Taubaté, 20/01/1904.

${ }^{14}$ IDEM, ibidem, p. 113. Carta de Taubaté, 1906 (sem data completa).

${ }^{15}$ IDEM, ibidem, p. 57. Carta de Taubaté, 20/01/1904.
} 
Observa-se também citações em torno da escrita empregada por Macuco, especificamente ao uso de adjetivos:

"Contei os adjetivos em Montaigne, Renan e Gorki. Sóbrios. Shakespeare,
quando quer pintar um cenário (um maravilhoso cenário shakespeariano!),
diz, seco: 'Uma rua'. O Macuco diria: 'Uma rua estreita, clara, poeirenta,
movimentada etc.'. O Macuco espalhou mais adjetivos pelo Belenzinho do
que gonococos - e nunca houve uma espingarda que o abatesse!...."16

Ao longo dos anos, o termo "Macuco" foi abrangendo escritores que se assemelhavam ao tal literato do Brás: “Os Macucos adquirem vocabulário unicamente para fazer alarde da "riqueza vocabular'" ${ }^{17}$. As críticas ultrapassaram a correspondência e viraram matéria literária, conforme Lobato confidencia a Rangel em 4 de maio de 1916: "Reeditei O plágio ${ }^{18}$. Não era bem conto, sim coisa para bulir com o Artur Goulart e os Macucos daquele tempo. Não tenho o talento da composição. Tudo me sai crônica. No fundo não passo dum cronista."19

No que se refere à autoria feminina, é de conhecimento o árduo caminho trilhado pela mulher, nos séculos passados e ainda no início do século $\mathrm{XX}$, para se inserir e, por que não, gozar de reconhecimento nos meios literários ${ }^{20}$. Júlia Lopes de Almeida (1862-1934) é uma das poucas escritoras que aparece nas páginas d'A barca de Gleyre: "Outra que anda enchendo as medidas é a Júlia Lopes - uma extraordinária mulher. Contos maravilhosos, únicos em nossa literatura. Conhece-os?"21

Anos mais tarde, Albertina Bertha (1880-1953) recebe as críticas de Monteiro Lobato, inclusive no artigo "Em pleno sonho", de $\mathrm{Na}$ antevéspera. O primeiro romance da autora, Exaltação, publicado em 1916, é bem recepcionado pela crítica, tendo Araripe Júnior recomendado sua publicação, episódio este que lhe rendera a alcunha de "padrinho" de Albertina Bertha ${ }^{22}$. Em carta de 23 de abril de 1916, Lobato opina:

\footnotetext{
${ }^{16}$ IDEM, ibidem, p. 96. Carta de Taubaté, 19/08/1905.

${ }^{17}$ IDEM, ibidem, p. 216. Carta de Areias, 30/08/1909.

${ }^{18}$ Conto de Monteiro Lobato publicado na Vida Moderna em 1915, na Revista do Brasil em outubro de 1918 e inserido no livro Cidades Mortas (1919).

${ }^{19}$ LOBATO, Monteiro. A barca de Gleyre. Ed. cit., p. 357. Carta da Fazenda, 15/05/1916.

${ }^{20}$ Cf. DUARTE, Constância Lima. "O canône e a autoria feminina". In: SCHMIDT, Rita Terezinha (Org.). Mulheres e literatura: (trans)formando identidades. Porto Alegre: Editora Palotti, 1997.

${ }^{21}$ LOBATO, Monteiro. A barca de Gleyre. Ed. cit., p. 158. Carta de Areias, 31/07/1907.

${ }^{22}$ Outros críticos que escreveram sobre Albertina Bertha: Lima Barreto, Almachio Diniz, Heitor Muniz, Homero Prates, Humberto de Campos, Orestes Barboza, Joaquim Tomaz, Thomaz Murat. Cf. MARTINS, Anna Faedrich. A produção de autoria feminina: Albertina Bertha e a imprensa periódica. Pontos de interrogação .Universidade do Estado da Bahia: Alagoinhas, Bahia, v. 2, p. 44-58, n. 1, jan./jun. 2012. Disponível em: http://www.poscritica.uneb.br/revistaponti/arquivos/volume2-n1/vol2n1-44-58.pdf. Acesso em: 16 out. 2013.
} 
"Comecei a ler Exaltação da Albertina Berta, o livro que assombrou o Araripe Júnior. Caso curioso. A mulher tem talento e até gênio, mas consegue destruir a ambos à força dum amaneirado de estilo que raia o grotesco. Lembra uma obra de D'Annunzio que um Zé Cantinho ou um Frango Sura ${ }^{23}$ reescrevesse na linguinha deles. Que pena! Com uma tesoura de podar, picando o livro e reduzindo-o à metade, eu faria dele uma coisa excelente. A mulher tem um grande talento, mas nenhum tato plástico."24

Ainda sobre a presença feminina em A barca de Gleyre, daremos um salto para a carta de $1^{\circ}$ de fevereiro de 1943. Lobato encontra em Maria José Dupré (1898-1984) aquilo que mais busca no texto literário, a propriedade linguística:

"Rangel: apareceu-nos uma senhora Dupré que está operando uma revolução literária. Está nos ensinando a escrever - e eu já muito aproveitei a lição. Revelou-me um tremendo segredo: o certo em literatura é escrever com o mínimo possível de literatura! Certo, porque desse modo somos lidos, como ela está sendo e como eu consegui ser nos livros em que me limpei de toda 'literatura'. Como nos envenenou aquela gente que andamos a ler na mocidade! Só agora me sinto completamente sarado, graças à medicação Dupré. Para que bem me entendas, terás de ler o ÉRAMOS SEIS, romance que a Editora acaba de publicar com um prefácio meu, que a autora não encomendou, pois nem sequer de vista a conheço. O caso me interessou tanto (li o livro em provas), que me lancei a esmiuçá-lo nesse prefácio." ${ }^{25}$

Com o prestígio de Monteiro Lobato enquanto escritor e, posteriormente, editor, os pedidos de prefácio eram tantos que ele chegou a organizar, em meados dos anos 1940, o livro Prefácios e entrevistas. Com a Sra. Leandro Dupré, segundo confessa em carta a Rangel, não houve pedido para prefaciar, a admiração por Éramos seis teria o impulsionado: "Numa noite o romance dessa mulher me ensinou mais literatura do que em cem anos a aprendi com os carranças e petrônios que quase me deixaram beribérico."26

$\mathrm{Na}$ analogia entre artes plásticas e literatura, Lobato relembra as preocupações estilísticas que acompanharam sua formação literária:

"Coisas que te disse antigamente confirmam-se agora, depois duma conversa tida com o Marques Campão, um pintor excelente e inteligente (coisa rara) e do livro da Dupré. Campão revelou-me o segredo da aquarela: não empastar as cores, não sobrepor tintas, pois só assim alcançamos o que nesse gênero há de mais belo: a transparência. No estilo literário dá-se a mesma coisa: o empastamento mata a transparência, tal qual nas aquarelas. Se eu digo 'céu azul', estou certo porque não sobrepus tintas e obtive transparência. Mas se venho com aqueles 'lindos' empastamentos literários que nos ensinaram ('céu azul-turquesa' - 'a cerúlea abóbada celeste'), estou

\footnotetext{
${ }^{23}$ Frango Sura é o apelido utilizado por Lobato para o escritor Manuel Francisco Pinto Pereira (1889-1956).

${ }^{24}$ LOBATO, Monteiro. A barca de Gleyre. Ed. cit., p. 353. Carta da Fazenda, 23/04/1916.

${ }^{25}$ IDEM, ibidem, p. 549. Carta de São Paulo, 01/02/1943.

${ }^{26}$ IDEM. "Prefácio ao Éramos seis, da Sra. Leandro Dupré". In: Prefácios e entrevistas. $3^{\mathrm{a} e d . ~ S a ̃ o ~ P a u l o: ~}$ Brasiliense, 1950, p. 57.
} 
fazendo literatura; e sobre a coisa linda que é a palavra 'azul' sobreponho um tom empastante 'turquesa' que no espírito do leitor irá sugerir a esposa dum Abud qualquer, ou 'cerúleo', que nos sugere cera, positivamente borro o azul do céu - em vez do céu lindo que eu quis descrever me sai uma 'literatura'. A Dupré mostrou-me que se pode escrever com zero de 'literatura' e cem por cento de vida. É o que estudo no prefácio.

"Parece incrível! Pois não é que com a tirada acima voltei atrás e estou naqueles tempos de Taubaté e Areias em que nos carteávamos semanalmente, a debater a eterna 'procura' dos nossos 'eus' literários?

"Como nos procuramos, Rangel - e parece que nos achamos... faltou-me naquele tempo uma Dupré mas a mim me salvaram as crianças. De tanto escrever para elas, simplifiquei-me, aproximei-me do certo (que é o claro, o transparente como o céu). ${ }^{27}$

Considerando a afirmação de Constância Lima Duarte, "raramente encontramos um nome feminino antes dos anos 40, quando folheamos manuais de literatura e as antologias brasileiras mais reconhecidas" 28 , as referências à escrita feminina n'A barca colocam Lobato numa posição diferenciada em relação a muitos críticos da época. Além de valorizar os romances de Maria José Dupré, ele indica a leitura a amigos como Rangel e Cesídio Ambrogi (1893-1974):

"Estou receitando a Dupré e a raspadeira a vários amigos de talento e ainda 'salváveis', como o Cesídio Ambrogi de Taubaté, o qual está tonto como quem tomou dose muito forte de 914. [...]

"Em teu caso, eu suspendia o novo livro até ver o efeito do remédio Dupré, pois que, apesar de cristalizado, te suponho ainda capaz de reagir à medicação - como o Cesídio está reagindo. Sem conhecer teu livro, juro que rasparias dele pelo menos meio quilo de 'literatura', como me aconteceu com Fábulas. "29

Em se tratando de modelos lobatianos, cabe notar que, segundo se discutiu no capítulo anterior, no período 1915-1917 Lobato demonstra grande preocupação com o estudo da língua portuguesa via literatura, inicialmente, nos textos portugueses e, com o tempo, nos brasileiros. Para Lobato, destacam-se Machado de Assis, escritor que concilia o uso correto da língua com um o estilo modelar; Euclides da Cunha, pela escrita enxuta e direta.

Aliás, nessa busca de um estilo de escrita que lhe seja exemplar, o emprego do adjetivo é analisado por Lobato em diferentes escritores. Critica Coelho Neto, referência para

\footnotetext{
${ }^{27}$ IDEM. A barca de Gleyre. Ed. cit., p. 549-50. Carta de São Paulo, 01/02/1943.

${ }^{28}$ DUARTE, Constância Lima. Op. cit., p. 57-8.

${ }^{29}$ LOBATO, Monteiro. A barca de Gleyre. Ed. cit., p. 550-1. Carta de São Paulo, 01/02/1943.
} 
muitos jovens, e para ele próprio ${ }^{30}$. É interessante observar o vocabulário crítico utilizado nas cartas. A escolha das palavras, na maioria das vezes, parte de uma realidade próxima, o que atrai até hoje leitores para A barca. Lobato preconiza: os adjetivos devem ser "podados":

"Ontem emergi do Turbilhão do Coelho Neto - um livro simples, sem esparramo de adjetivos, sem pompas orientais, dum Coelho Neto evidentemente podado a podão e tesoura (shears em inglês é tesoura de podar; nós não temos a palavra). Os tipos são fotograficamente montados e de tudo resulta a montagem fotográfica do avacalhamento moral e social da família carioca $[\ldots] ., 31$

Verifica-se também em outras cartas que Lobato costumava referir-se ao processo de criação por meio de "metáforas vivas", aquilo que Almuth Grésillon chama de metáforas organicistas da escrita. Neste sentido, encontramos termos como "gestação" e "parto" aludindo à gênese de alguns de seus textos ${ }^{32}$.

O cronista João do Rio, pseudônimo de Paulo Barreto (1881-1921), merece a atenção de Lobato:

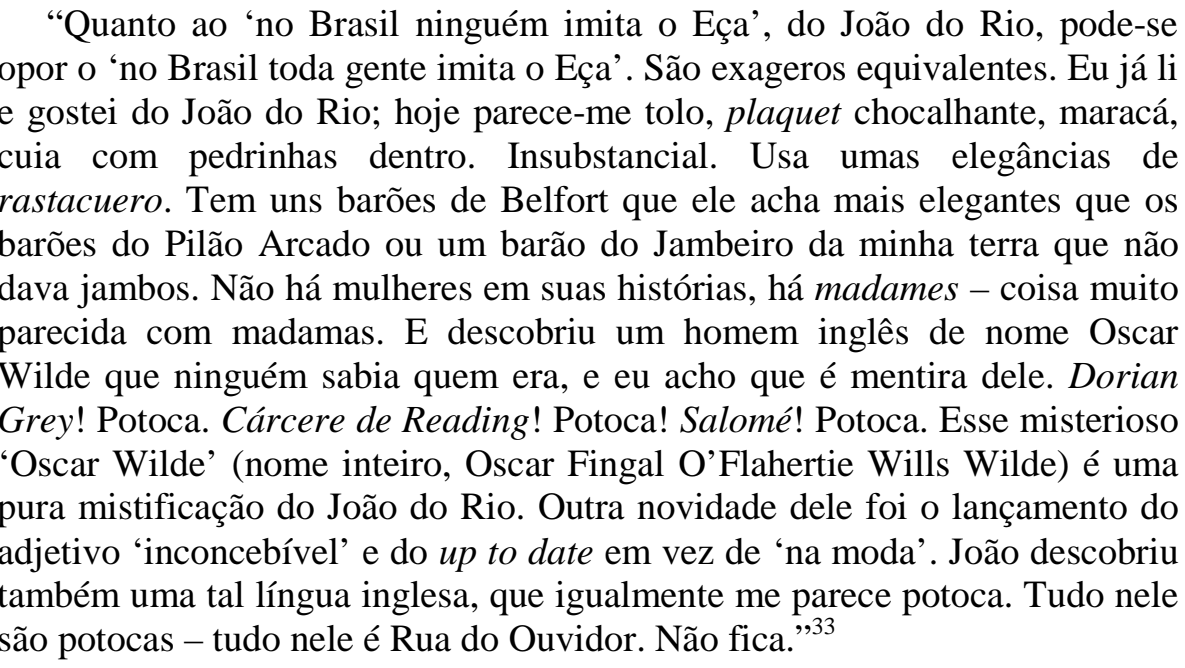

Pode-se ver que Lobato não apreciava João do Rio e que a vida de Oscar Wilde não era tão conhecida no Brasil, como lembra Brito Broca ${ }^{34}$. A crítica recaí também sobre a escrita do cronista carioca, "imitada" de Eça de Queirós, cuja linguagem é desaprovada por Lobato, como vimos no capítulo anterior.

\footnotetext{
${ }^{30}$ Cf. ENDALÉCIO, Raquel Nunes. A (re) Construção do mundo clássico na obra de Monteiro Lobato: fontes e procedimentos. Dissertação de Mestrado (orientação Marcos Antonio de Moraes). São Paulo, Instituto de Estudos Brasileiros, Universidade de São Paulo, 2013.

${ }^{31}$ LOBATO, Monteiro. A barca de Gleyre. Ed. cit., p. 313. Carta da Fazenda, 17/05/1915.

32 GRÉSILLON, Almuth. Devagar obras. In: ZULAR, Roberto. Criação em processo: ensaios de crítica genética. São Paulo: FAPESP/Iluminuras, 2002, p. 150.

${ }_{33}^{33}$ LOBATO, Monteiro. A barca de Gleyre. Ed. cit., p. 302. Carta da Fazenda, 30/01/1915.

${ }^{34}$ BROCA, Brito. A vida literária no Brasil $-1900.5^{a}$ ed. Rio de Janeiro: José Olympio, Academia Brasileira de Letras, 2005, p. 164.
} 
A carta de 30 de setembro de 1915 é importante por exibir um escritor atento aos estudos da língua e à propriedade vocabular dos adjetivos:

"O pior vezo nacional é cevar o estilo como se cevam porcos. O ideal literário parece que é a banha. Está gordinho? Ah, então está lindo.

"Toca a jejuar até emagrecer às justas proporções - jejuar de adjetivos modificatório. São a gafa. O qualificativo é tinta boa, viva, crua; o modificativo é água diluente, dessorante: 'Raiava um céu azul'; o azul está forte, na pureza com que sai dum tubinho do Ceruleum blue do Windsor \& Newton. Posponha-se lhe um 'desmaiado'.

“Raiava um céu azul desmaiado...

“Adeus, vigor! Junte-se mais um 'diáfano',

“Raiava um céu azul, desmaiado, diáfano...

"e do Portugal nervoso de Camilo saltamos para o Brasil toucinhento de João do Rio. Já é aquarela, água rala, água panada, pintura de moça. Dirão: 'E um gênero como outro qualquer'. Sim, mas que não sobrevive como sobrevivem os fortes claro-escuros de Rembrandt - e o tudo na biologia é sobreviver. O que já nasceu desbotado continua a desbotar pela ação do tempo." ${ }^{35}$

Não só as preocupações linguísticas afligem o escritor em formação. A carta de 22 de novembro de 1914 revela um Lobato que lê José de Alencar (1829-1877) e posiciona-se frente ao indianismo romântico:

"Como você vê, não é fantasia nem carocha. É uma coisa que está aí e ninguém vê por causa do tal prisma. Rangel, é preciso matar o caboclo que evoluiu dos índios de Alencar e veio até Coelho Neto - e que até o Ricardo romantizou tão lindo:

“Cisma o caboclo à porta da cabana...

"Eu vou contar o que ele cisma. A nossa literatura é fabricada nas cidades por sujeitos que não penetram nos campos de medo dos carrapatos. E se por acaso um deles se atreve e faz uma 'entrada', a novidade do cenário embotalhe a visão, atrapalha-o, e ele, por comodidade, entra a ver o velho caboclo romântico já cristalizado - e até vê caipirinhas cor de jambo, como o Fagundes Varela. O meio de curar esses homens de letras é retificar-lhes a visão. Como? Dando a cada um, ao Coelho Neto, à Júlia Lopes, uma fazenda na serra para que a administrem. Se eu não houvesse virado fazendeiro e visto como é realmente a coisa, o mais certo era estar lá na cidade a perpetuar a visão erradíssima do nosso homem rural. O romantismo indianista foi todo ele uma tremenda mentira; e morto o indianismo, os nossos escritores o que fizeram foi mudar a ostra. Conservaram a casca... Em vez de índio, caboclo." 36

\footnotetext{
${ }^{35}$ LOBATO, Monteiro. A barca de Gleyre. Ed. cit., p. 332. Carta da Fazenda, 30/09/1915.
}

${ }^{36}$ IDEM, ibidem, p. 291-2. Carta da Fazenda, 22/11/1914. 
Enviada dez dias após a publicação do artigo "Uma velha praga" e um mês antes da saída de "Urupês", a carta reúne reflexões do Lobato criador do personagem Jeca Tatu. Assim, critica escritores como José de Alencar, Fagundes Varela, Coelho Neto e Júlia Lopes de Almeida, entre outros, pela visão mitificada do homem do campo. Segundo sua correspondência, Monteiro Lobato sentia-se mais próximo dessa realidade porque tivera a oportunidade de viver de perto o universo caipira em sua experiência como fazendeiro nas terras do Buquira.

Não se sabe precisar quais foram as obras de José de Alencar lidas por Lobato, mas a carta de 17 de março de 1916 apoia a hipótese de que ele leu $O$ Guarani e estendeu o julgamento a outros romances: “[...] Não conheço As minas de prata do velho Alencar, mas juro que também lá ele falsifica o homem - embelezando-o. Os índios de Alencar no Guarani são pescados na Ilíada de Homero." 37 Talvez Lobato não tenha lido a obra ou tenha feito uma leitura posterior à carta, pois o Fundo Monteiro Lobato da Unicamp guarda um exemplar de As minas de prata, edição de 1923 da Livraria Garnier ${ }^{38}$.

É preciso dizer que, mesmo mais próximo da realidade brasileira nesse momento, Lobato parecia ainda estar preso às teorias deterministas de Le Bon e Taine. Porém, quando entra em contato com livros ligados às campanhas higienistas dos médicos Belisário Pena e Artur Neiva, compreende o Jeca não mais como maldição social, e sim, fruto do subdesenvolvimento que gera a fome, a doença e a miséria ${ }^{39}$.

Campanhas sanitaristas? Sobre quais outros assuntos Monteiro Lobato também lia? Ao longo deste trabalho, foram indicados diferentes autores e gêneros aludidos em A barca de Gleyre. Textos literários, críticos, verbetes, discursos... até mesmo um tratado sobre a criação de galinhas! $!^{40}$

\footnotetext{
${ }^{37}$ IDEM, ibidem, p. 348. Carta da Fazenda, 17/03/1916.

38 ALENCAR, José. As minas de prata. Rio de Janeiro: Livraria Garnier, 1923. Localização no acervo CEDAE/IEL/UNICAMP: código MLb 800037.

${ }^{39}$ AZEVEDO, Carmen Lúcia de; CAMARGOS, Márcia; SACCHETTA, Vladimir. Monteiro Lobato: furacão na Botocúndia. São Paulo: SENAC, 1997, p. 112.

${ }^{40}$ Em meio à vida da Fazenda, Lobato escreve em 19 de agosto de 1912: "Ontem, a Galinocultura de Delgado de Carvalho me enlevou a cabeça e a alma, como outrora as enlevava um romance de Daudet." Em sua tese de doutorado, Armando João Dalla Costa afirma que o Tratado de galinocultura, de Delgado de Carvalho, avicultor e autor de diversas publicações, estava entre os mais lidos na época. Cf. COSTA, Armando João Dalla. Agroindústria brasileira contemporânea: Inovações organizacionais e transformações tecnológicas na avicultura. Tese de Doutorado (orientação de M. Guy Martinière). Paris, França: Université de la Sorbonne Nouvelle Paris III, 1997, p. 60. Disponível em: http://www.empresas.ufpr.br/teseajd.pdf Acesso em 14 out. 2013.
} 
O orador Rui Barbosa (1849-1923), além de ser assunto dos missivistas, tinha seus discursos compartilhados, como mostra a carta de 2 de janeiro de 1909: "Seguem os discursos do Rui aqui em São Paulo. São catedrais de Chartres, Rangel!"

Em 1909, Lobato ocupa o cargo de promotor público na cidade de Areias e Rangel é nomeado juiz municipal de Machado, Minas Gerais; logo, o meio pelo qual ambos acompanham os discursos de Rui Barbosa no Rio de Janeiro, mais precisamente, na Academia Brasileira de Letras, é pela leitura das peças de oratória. É como presidente da ABL que Rui saúda Anatole France na sua passagem pelo Rio de Janeiro, em maio, 1909, visita esta registrada por Brito Broca ${ }^{42}$. Nas cartas, o episódio é também lembrado por Lobato:

"Ando a regalar-me com Macaulay nos Essays. É uma espécie de Rui Barbosa da história e da crítica - e por falar: leu o discurso de Rui saudando o Anatole France? Este o classificou de mais uma bela página acrescentada à literatura francesa - e não o disse por amabilidade porque é mesmo. Rui é positivamente grande como o mar." 43

Ao lado de Machado de Assis e Euclides da Cunha, o escritor conhecido como Águia de Haia, é admirado e respeitado por Lobato, que lhe dedica contabilizadas horas de leitura:

"Gastei 240 minutos ontem lendo o discurso de Juiz de Fora. Que assombro de homem, esse Rui! Que cetáceo, neste nosso marzinho de arenques! Ele rege as frases como um cocheiro russo rege a troika! Que nababo! Pare com o Camões e o Cervantes e pegue no Rui: ele resume-os a todos e é do nosso tempo. Acho uma honra tremenda sermos coevos de tal homem, e duvido que tenhamos outra semelhante na vida. Aprendamos a degustá-lo como ao rei da língua. É uma espécie de Império Britânico do vernáculo. Eu saio dele mais chato que um percevejo." ${ }^{4}$

No presente trabalho não pretendemos analisar os limites literários da escrita de Rui Barbosa, já discutidos por críticos como Antonio Candido e Alfredo Bosi ${ }^{45}$. Entre as variadas leituras praticadas por Lobato, não poderíamos deixar de mencioná-lo.

Se para a época Rui Barbosa tornou-se uma lenda justamente por sua eloquência, a correspondência d'A barca de Gleyre contribui para reforçar essa imagem:

\footnotetext{
${ }^{41}$ LOBATO, Monteiro. A barca de Gleyre. Ed. cit., p. 193. Carta de São Paulo, 02/01/1909.

${ }^{42}$ BROCA, Brito. Op. cit., p. 230-6.

${ }^{43}$ LOBATO, Monteiro. A barca de Gleyre. Ed. cit., p. 200. Carta de Areias, 27/06/1909.

${ }^{44}$ IDEM, ibidem, p. 203. Carta de Areias, 01/07/1909.

${ }^{45}$ Cf. PAGLIONE, Eduardo Augusto. Rui Barbosa: Direito e Literatura. Em tempo. Revista da Faculdade de Direito de Marília. v. 4, Marília: Fundação de Ensino Eurípedes Soares da Rocha, ago./2002. http://galileu.fundanet.br/revista/index.php/emtempo/article/viewFile/120/145.
} 
"Tens os discursos do Rui? Que maravilha! Que deslumbramento! Que incomparável mestre e que artista da palavra! É o grande clássico que nos dispensa de lidar com os velhos clássicos - tudo que neles há de bom aparece em Rui, e melhorado. Tem todas as energias e todas as suavidades. Rui é um Everest."

Em 1916, Lobato aponta deficiências no quadro literário da época e conclui:

"Apesar da pulga geográfica que é, Portugal nos bate quantitativa e qualitativamente - se pusermos de fora Machado, Rui e Euclides. A produção intelectual é lá maior que a nossa, e hoje refervem na fúria dum pequeno Renascimento. Renascem, e nós nem conseguimos morrer [...]."47

Entretanto, como já foi mencionado em outros momentos desta dissertação, a opinião de Lobato frente a alguns autores e obras sofre variação ao longo do tempo, fato este que não o torna diferente, mas igual a qualquer leitor! A carta de 11 de outubro de 1917, praticamente toda dedicada a Rui Barbosa, mescla admiração e questionamentos:

"Rui Barbosa me dá a impressão, na ciência, duma superposição de autores; no estilo, duma superposição de clássicos. Vejo nele Vieira, Bernardes, Latino, Frei Luís, Herculano, Camilo - dele pessoalmente, só a sabedoria e fina arte do misturador. Rui é uma grande Central telefônica a que vão ter todos os fios; e do conglomerado ressoa uma voz eólia, de qualquer lado que bata o vento. É uma focalização. Toda a ciência, toda a literatura de todos os tempos e povos converge seus raios naquele refletor mental que os emburilha, funde e dá - como as cores fundidas dão a luz branca - esse clarão cegante, excessivo, que atrai todas as mariposas e afugenta todos os morcegos: RUI BARBOSA." 48

A literatura portuguesa não só desperta Lobato para os estudos da língua como the concede um repertório a partir do qual ele estabelece relações literárias, em um exercício constante de leitura e análise estilística. Assim, enxerga em Rui Barbosa a assimilação de autores portugueses e lhe critica a dificuldade de inovar:

"Rui tem o gênio dos cadinhos: funde. Falta-lhe o gênio das retortas: que cria. Rui dá 'misturas' geniais; não dá 'combinações' novas. Tenho para mim que Rui é muito mais Força da Natureza do que Força Individual. É um estuário amplíssimo onde cada punhado d'água que tomemos mostra o nome do afluente contribuinte; ou cada folha ou flor carreada conta de que árvore caiu.

"Acho Rui imenso como o Amazonas, mas sem a imensidade dum Shakespeare, dum Nietzsche, dum qualquer Grande Emissor de ideias. Dele me disse ainda há pouco Martim Francisco, em Santos: 'Rui é um grande escritor sem talento: porque não cria'. Nada mais falso. Impossível talento maior que o de Rui. Chega até as raias da genialidade - mas fica-se na categoria do gênio sem medula criadora." ${ }^{, 9}$

\footnotetext{
${ }^{46}$ LOBATO, Monteiro. A barca de Gleyre. Ed. cit., p. 224. Carta de Areias, 15/09/1909.

${ }^{47}$ IDEM, ibidem, p. 351. Carta da Fazenda, 15/04/1916.

${ }^{48}$ IDEM, ibidem, p. 409. Carta de Caçapava, 11/10/1917.

${ }^{49}$ IDEM, ibidem, p. 409. Carta de Caçapava, 11/10/1917.
} 
É interessante notar que n'A barca verificam-se diversos momentos nos quais Lobato entrega-se a leitura como estudo e exercício, compreendendo a assimilação de estilos como parte de sua formação literária. Porém, critica Rui Barbosa por reconhecer nele apenas outros escritores. Essa postura parece ter fundamentação que ultrapassa aspectos literários e liga-se, na verdade, a divergências de ordem política:

"Eu já tive o meu período febril de ruísmo, igual ao teu de hoje: foi em fins de Afonso Pena e Nilo e todo o Hermes. Aquele Rui combativo, cruel como Jeová, feroz como Ezequiel, foi a culminância do 'fenômeno Rui'. Mas ainda nessa fase funcionou como o refletor de todas as ânsias, queixas e desejos da nação. Fez-se Voz da Natureza, Boca do País. Naquele tempo, por politica, estavas divorciado dele. Tentei conversar contigo sobre a Águia que depenava o Avestruz e tu fugiste com o corpo. Hoje dá-se o contrário. Eu é que estou divorciado de Rui... por motivos bélicos. E não o leio. Como torço pela vitória da Alemanha e Rui é o paladino da derrota alemã, resumo a minha opinião sobre ele com a imbecilidade dum calouro: 'É uma besta!' Mas sei ou sinto que isso é pura imbecilidade minha diante de imbecis ainda maiores que eu. E se não o leio é na certeza de que se o ler, a 'besta' me converte com a sua lógica de aço e cá me põe o germanismo de cuecas, de pernas para o ar. Porque o meu germanismo tem fundamentos grotescos: a causa número 1 é ser aliadófilo o meu barbeiro; a número 2 é serem aliados o Estado de S. Paulo, todos os meus amigos e toda gente. Germanizando, eu me isolo do barbeiro, do jornal e duma súcia de amigos. Pura questão de higiene mental." 50

Na defesa de sua posição “anti-ruísmo", Lobato manifesta, ironicamente, sua adesão à Alemanha, diretamente referindo-se a Primeira Guerra Mundial. Entretanto, confessa sua deficiência crítica no assunto, uma vez que se nega a ler essa faceta de Rui Barbosa por receio de ser convencido pela argumentação do notável orador ${ }^{51}$.

Antes de prosseguir tomando outras leituras feitas por nosso escritor, uma última análise sobre a presença do Águia de Haia.

A publicação de Urupês, em 1918, é bem recebida pelo público e são feitas novas edições em um curto espaço de tempo, como o próprio Lobato comenta em suas cartas a Rangel. A popularidade da obra é ainda maior por conta do discurso de Rui Barbosa, em plena campanha à Presidência da República, proferido em 20 de março de 1919, no Teatro Lírico do Rio de Janeiro: “Conheceis, porventura, o Jeca Tatu, dos Urupês, de Monteiro Lobato, o admirável escritor paulista?".

\footnotetext{
${ }^{50}$ IDEM, ibidem, p. 409-10. Carta de Caçapava, 11/10/1917.

${ }^{51}$ No texto A Alemanha de Lobato, Lucila Bassan Zorzato pontua aspectos desse germanismo de Monteiro Lobato através da carta de 11 de outubro de 1917, enviada a Rangel, e outra a Antonio Salles (sem data). Disponível em: http://ebooks.pucrs.br/edipucrs/anais/Xsemanadeletras/comunicacoes/Lucila-Bassan-Zorzato.pdf Acesso em: 17 out. 2012.
} 
Se até agora o presente trabalho focalizou o percurso de Lobato leitor e escritor em formação, recorreu a esse episódio envolvendo Rui Barbosa justamente para ilustrar como essa relação com os autores e a literatura vai sendo modificada à medida que o criador do Jeca começa a consolidar seu nome no jornalismo e na literatura, além de se estabelecer no mercado editorial. Vamos verificar como isto se dá.

\section{$\underline{\text { Um escritor entre jornalistas e escritores... }}$}

"Sou hoje um dos que decidem do destino das coisas literárias do país." Monteiro Lobato ${ }^{52}$

O final do ano de 1914 é sem dúvida um divisor de águas na trajetória de Monteiro Lobato. Isto porque com a publicação dos artigos "Uma velha praga" e "Urupês", ambos n' $O$ Estado S. Paulo, nosso escritor começa a sentir os efeitos de seus textos na imprensa paulista.

Com os artigos reproduzidos em outros periódicos, Lobato é também alvo de comentários pelo grupo de intelectuais do Estado, que o consideram "novo de forma" e uma "revelação", conforme ele relata em carta ao amigo em 12 de fevereiro de $1915^{53}$. O vínculo com o jornal não significa apenas possibilidades financeiras; na verdade, significa o crescimento de seu público leitor que o impulsiona a mergulhar na imprensa de massa:

"Dizes bem quanto à disseminação do nome por intermédio de outras folhas. Isto é como eleitorado. Escrevendo no Estado, consigo um corpo de oitenta mil leitores, dada a circulação de quarenta mil do jornal e atribuindo a média de dois leitores para cada exemplar. Ora, se me introduzir num jornal do Rio de tiragem equivalente, já consigo dobrar o meu eleitorado. Ser lido por duzentas mil pessoas é ir gravando o nome - e isso ajuda. [...]

"Veja você como para o mundo tem peso um nome que assina artigos no jornal. A gente passa de servo da gleba à classe dos senhores." ${ }^{, 54}$

O jovem Lobato, leitor e escritor em formação, vai aos poucos cedendo espaço ao respeitado Monteiro Lobato, colaborador d'O Estado de S. Paulo, reconhecido oficialmente

\footnotetext{
${ }^{52}$ LOBATO, Monteiro. A barca de Gleyre. Ed. cit., p. 422. Carta de São Paulo, 08/07/1918.

${ }^{53}$ IDEM, ibidem, p. 305-6. Carta da Fazenda, 12/02/1915.

${ }^{54}$ IDEM, ibidem, p. 306. Carta da Fazenda, 12/02/1915.
} 
perante a intelectualidade paulistana, com o convite para a conferência na Sociedade de Cultura Artística de São Paulo ${ }^{55}$.

Até aqui, foi analisado, principalmente, o perfil de Lobato enquanto leitor, durante os anos de sua formação literária. Foi-se o tempo do estudante que se deliciava com aventuras tartarinescas e idealizava uma trajetória literária no molde de escritores já consagrados. Passaram-se também as longas horas dedicadas às leituras na pacata cidade de Areias em meio à rotina do juiz interino. Nasce o Lobato que não só se interessa pela crítica de escritores brasileiros, mas que participa ativamente da cena intelectual de São Paulo.

O nacionalismo lobatiano vai se intensificando, assunto abordado no capítulo "De encontro a ou ao encontro de? Lobato e a França", e adquire novos contornos devido a sua presença de articulista na grande imprensa. Em 1917, de volta à cidade de São Paulo, após a venda da fazenda do Buquira, Lobato escreve para os periódicos Vida Moderna, O Queixoso, Parafuso, A Cigarra, O Pirralho, O Estado de S. Paulo e Revista do Brasil. O melhor de sua produção é reservado para estes dois últimos, segundo os biógrafos em Monteiro Lobato: Furacão na Botocúndia. ${ }^{56}$

Começa a colaborar na Revista do Brasil, no terceiro número, em março de 1916, com o conto "A vingança da peroba", e, desse momento em diante, ali, publica contos, artigos e crítica de artes plásticas. Sua trajetória de sucesso é marcada pela compra da Revista do Brasil, em 1918, na qual autofinancia a publicação de O Saci-Pererê: resultado de um inquérito e Urupês.

Essa contextualização é imprescindível para entender as relações de nosso escritor com a literatura brasileira. Isto se deve ao fato de que muito daquilo que Lobato lia estava de algum modo relacionado ao círculo de amigos do Estado de S. Paulo ou aos colaboradores da Revista do Brasil.

Em 1918, a correspondência testemunha como o Lobato leitor convive com a faceta do editor e, segundo a biografia Furacão na Botocúndia, em setembro, Lima Barreto (18811922) é convidado por Lobato para colaborar no periódico e na editora:

\footnotetext{
${ }^{55}$ CHIARELLI, Tadeu. Op. cit., p. 109.

${ }^{56}$ AZEVEDO, Carmen Lúcia de; CAMARGOS, Márcia; SACCHETTA, Vladimir. Op. cit., p. 119.
} 
"A Revista do Brasil deseja ardentemente vê-lo entre os seus colaboradores. Ninhos de medalhões e pérolas, ela clama por gente interessante que dê coisas que caiam no gosto do público. E Lima Barreto, mais do que nenhum outro, possui o segredo de bem ver e melhor dizer, sem nenhuma dessas preocupaçõezinhas de toilette gramatical que inutiliza metade dos nossos autores. Queremos contos, romances, o diabo, mais à moda do 'Policarpo Quaresma', da 'Bruzundanga', etc." 57 '

Segundo Cilza Carla Bignotto, as ideias de Lima Barreto sobre arte e literatura tinham muitos pontos em comum com as de Monteiro Lobato, destacando-se o olhar para os problemas nacionais, a busca de uma linguagem mais "brasileira" e o combate ao academicismo. Deste modo, era importante atraí-lo para a Revista do Brasil ${ }^{58}$.

Lobato recebe, como resposta ao seu convite, os originais do romance Vida e morte de M. J. Gonzaga de Sá. Embora o atarefado cotidiano lhe restringisse o tempo destinado às leituras, se comparado ao da época em que residia em Areias ou na fazenda do Buquira, a dedicação a Lima Barreto é externada a Rangel:

"Como ainda estou de resguardo e preso em casa, leio como bons tempos de Taubaté. Fechei neste momento um romance de Lima Barreto, Isaias Caminha. É dos tais legíveis de cabo a rabo. Romancista de verdade. Amanhã vou assinar com ele contrato para a edição dum livro novo, Vida e morte de M. J. Gonzaga de Sá, cujos originais já estão aqui. A letra é infamérrima e irregularíssima. Há trechos em que o autor positivamente cambaleia, e outros em que para para 'destripar o mico'. Mas quanto talento e do bom!" 59

Os negócios editorias efetivam-se e, no ano seguinte, o romance de Lima Barreto sai pela Revista do Brasil. Embora tenha sido a publicação mais bem paga na editora, o livro não alcançou a popularidade esperada ${ }^{60}$. Da experiência editorial, não só advêm os textos, mas a troca epistolar, durante o período 1918-1922, reunida por Edgard Cavalheiro em $A$ correspondência entre Monteiro Lobato e Lima Barreto ${ }^{61}$. Ao lado deste, Martim Francisco e Paulo Setúbal também estão entre os primeiros autores editados pela Revista do Brasil. ${ }^{62}$

\footnotetext{
${ }^{57}$ CAVALHEIRO, Edgard (Org.) A correspondência entre Monteiro Lobato e Lima Barreto. Rio de Janeiro: Ministério da Educação e Cultura. Serviço de Documentação, 1955, p. 13.

${ }^{58}$ BIGNOTTO, Cilza Carla. Novas perspectivas sobre as práticas editoriais de Monteiro Lobato (1918-1925). Tese de Doutorado (orientação Marisa Philbert Lajolo). Campinas, São Paulo: Instituto de Estudos da Linguagem, Universidade Estadual de Campinas, 2007, p. 215.

${ }^{59}$ LOBATO, Monteiro. A barca de Gleyre. Ed. cit., p. 431. Carta de São Paulo, 24/11/1918.

${ }^{60}$ Cf. MACIEL, Rodrigo Lima. O cenário editorial de Vida e morte de M.J. Gonzaga de Sá, de Lima Barreto. Inventário (PPGLL/UFBA). Salvador, Bahia, UFBA, 12 ed., jan.-ju.1/2013. Disponível em: http://www.inventario.ufba.br/12/O\%20cen\%C3\%A1rio\%20editorial.pdf. Acesso em: 17 set. 2013.

${ }^{61}$ CAVALHEIRO, Edgard. A correspondência entre Monteiro Lobato e Lima Barreto. Ed. cit.

${ }^{62}$ BIGNOTTO, Cilza Carla. Op. cit., p. 211.
} 
Leitor, editor e amigo! O sucesso de Monteiro Lobato e o interesse que demonstra em publicar novos autores amplia sua rede de sociabilidade com a inclusão dos que desejam se projetar na literatura:

"Quando correu a notícia da procura por coisas inéditas, de autores que não
se encaixavam em nenhuma dessas categorias, passaram a chover originais
de todos os recantos do país, como se de repente o Brasil atravessasse uma
fase de inusitado brilho no campo da literatura. Centenas de textos
engavetados vieram à luz do dia graças à sua política editorial." 63

Em carta de 9 de novembro de 1921, Lobato compartilha com Rangel suas ambições editorias: "Meu empenho é só editar novos, mas novos de talento. Medalhão não me entra aqui. Que gosto soltar livros de múmias acadêmicas, gente rançosa? Quero tendrons, brotos. Sinto-me velho, e para burro velho, pasto novo - diz o Manequinho Lopes." $" 64$

Aliás, essa atenção dedicada a escritores que despontavam na literatura brasileira já se manifestara em cartas anteriores à compra da Revista do Brasil. Na missiva de 8 de julho de 1917, verifica-se o quanto Lobato estava a par do movimento literário na época:

"Mas vem surgindo um Guilherme de Almeida, cujo Nós revela muita coisa. Parece-me poeta de verdade - não apenas burilador de versos como o F., ou parnasiano de miolo mole, essas venerandas relíquias do passado, Alberto [de Oliveira] etc. E Bilac, que era a salvação, deu agora para rimar filosofia alheia e fazer patriotismo fardado. Alberto está um perfeito vieux beau.[...]

"Guilherme é o balbucio duma corrente nova que acabará levando para o bueiro os lecomtistas de cabelos pintados com Juventude Alexandre. Tenho muita fé nesse menino de Almeida. São os dois de São Paulo: Vicente de Carvalho, glória legítima mas já sem uma asa, e Guilherme, uma linda manhã. O espaço entre ambos é interestelar: é o Saco de Carvão da Via Láctea. Menotti também desponta, meio papagaio ainda, meio discursante; mas é capaz de dar coisa. Tem coragem. O resto, meu caro, é saparia de lagoa; coaxam rimadamente. No romance irrompeu o Veiga Miranda. Redenção é positivamente bom, apesar da descaída do final. Como é difícil manter um romance no crescendo! Se a política (a dos políticos e a literária) o não arrastar, teremos em Veiga um verdadeiro valor. Lembro-me d' $O$ margarida - o seu desastrado conto de estreia na Revista do Brasil. Pois evoluiu e melhorou muito. E é só naquele São Paulo - uma cidade de 500 mil habitantes! Que penúria, hein?"65

Guilherme de Almeida (1890-1969) está no catálogo dos editados por Monteiro Lobato sob o selo da Revista do Brasil, com a poesia do Livro de horas de Soror Dolorosa. Entre os "novos" lançados pela Revista alinham-se Albertino Moreira, Hilário Tácito

\footnotetext{
${ }^{63}$ AZEVEDO, Carmen Lúcia de; CAMARGOS, Márcia; SACCHETTA, Vladimir. Op. cit., p. 124.

${ }^{64}$ LOBATO, Monteiro. A barca de Gleyre. Ed. cit., p. 472. Carta de São Paulo, 09/11/1921.

${ }^{65}$ IDEM, ibidem, p. 400-1. Carta da Fazenda, 08/07/1917.
} 
(pseudônimo de Joaquim Maria de Toledo Malta), Léo Vaz, Paulo Setúbal, Oliveira Vianna e Renato Kehl.

Leonel Vaz de Barros (1890-1973), literariamente conhecido como Léo Vaz, fora apresentado a Lobato por Oswald de Andrade, passando a frequentar o escritório da Revista do Brasil $^{66}$. O jovem escritor, recém-chegado da cidade de Piracicaba, teria encontrado em Lobato um amigo e também entusiasta de seus textos. ${ }^{67}$ Com a publicação do romance $O$ professor Jeremias, em 1920, pela Revista, o sucesso é comemorado e vira assunto com Rangel: "Estrondoso triunfo está tendo o Léo Vaz. A primeira edição do Jeremias esgotou-se antes que os jornais tivessem tempo de falar - em pouco mais de quinze dias!...."68.

Além de estar atento à produção literária, Lobato demonstra que seu tato crítico o acompanha na trajetória de editor. Assim, julga os títulos recém-publicados e, segundo seu costume, os compara:

"Flama e argila não é livro vulgar, mas não fixa tipos. Li-o e conservo nomes na cabeça, mas 'não vejo' as criaturas. Tem tido crítica ótima, mas o Menotti me disse que se vende pouco. O Jeremias, sim, está tendo saída excelente. Leste-o? Perpassa nele um humorismo displicente de quem não quer - tal qual o autor. Aquilo é o Léo escarrado. Uma espécie de Machado de Assis sem a gagueira. São Paulo está se saindo. Os 'novos' entram 'feitos' e impõem-se de jato. Eu, o Léo, o Menotti e vai ver que também o Malta." 69

Embora Flama e argila, de Menotti del Picchia, não integre o catálogo da editora, Lobato não deixa de mencionar o romance, mostrando-se cuidadoso não só como editor, mas enquanto leitor e crítico. Cabe destacar que nosso escritor se insere entre os "novos" que estão conquistando seu espaço na literatura, muito provavelmente referindo-se a boa saída de suas primeiras publicações - O Saci-Pererê: resultado de um inquérito e Urupês.

Hilário Tácito, o Malta, é o último citado na lista dos estreantes. A relação com o editor é tanto de amizade quanto de negócios; inclusive, é ele quem assina o prefácio do primeiro livro de Godofredo Rangel, Vida ociosa, encomendado pelo próprio Lobato, em $1920^{70}$.

\footnotetext{
${ }^{66}$ BIGNOTTO, Cilza Carla. Op. cit., p. 207.

${ }^{67}$ Lobato costumava comparar Léo Vaz a Machado de Assis, como se verifica em algumas cartas, entre elas, a de 5 de novembro de 1919: "Estou editando um livro à Machado de Assis, de um novo, Léo Vaz." LOBATO, Monteiro. A barca de Gleyre. Ed. cit., p. 445. Carta de São Paulo, 05/11/1919.

${ }^{68}$ IDEM, ibidem, p. 451. Carta de São Paulo, 14/02/1920.

${ }^{69}$ IDEM, ibidem, p. 453. Carta de São Paulo, 23/03/1920.

${ }^{70}$ IDEM, ibidem, p. 456. Carta de São Paulo, 29/11/1920.
} 
Vale destacar que essa atenção aos novatos caracteriza-se por diferentes iniciativas adotadas pelo arguto editor. Embora distante do período que está sendo discutido no presente capítulo, é por meio da carta de 13 de julho de 1946 que se descobre mais sobre a atuação de Lobato na Revista do Brasil:

"Ontem fui visitar o velho Galvez, que é ainda a maior figura do romance argentino. Recordou os bons tempos da Revista do Brasil, quando ele e eu e você e todos nós começávamos a vagir em público. Eu editei-lhe a Nancha regules em português - e vi lá em sua estante o volume, ainda com a faixa amarela com que saiu. Perguntou-me pelo Hilário Tácito, pelo Léo Vaz e por você. Eu havia mandado a ele todas aquelas nossas primeiras edições e ele as lera todas. Estava no período da leitura., ${ }^{, 1}$

Aqui, vemos o quanto Lobato também se empenha em divulgar a produção literária brasileira em outros países. Manuel Gálvez (1882-1962), proprietário da Editorial Patria, de Buenos Aires, trocou cartas com Lobato a partir de 1919, a propósito da publicação de Urupês na Argentina, concretizada na capital portenha em 1921. É claro que a correspondência entre o argentino e o brasileiro reforça o papel da rede de sociabilidade na trajetória do escritor ${ }^{72}$.

Para entender um pouco melhor o convívio de Lobato com os intelectuais, vale recorrer a Léo Vaz que, além de escritor e amigo, era o secretário de redação da Revista cujo cotidiano se mostra nas Páginas vadias:

“[...] tudo quanto era escritor, artista, jornalista, poeta, pensador, ou mero 'sapo' em algum desses setores, tinha ali naquelas duas saletas o seu habitual ponto de encontro. Com o que o expediente da Revista só vigorava mesmo, e produzia o que lhe era indispensável, no período da manha [...] À tarde, a Revista virava clube ou tertúlia, onde compareciam, cavaqueavam, discutiam, ou tiravam uma furtiva soneca, os mais variados, heterogêneos e desencontrados espécimes intelectuais, desde o importante Martim Francisco, sempre aparentado um ar de conspirador do Primeiro Império, até um maluco, egresso do Juqueri, colombiano e sem teto, que Lobato certa noite deparara a vaguear pelo Anhangabaú. Entre esses extremos, eram obrigatórias ou esporádicas presenças as de Artur Neiva, Manequinho Lopes, Plínio Barreto, Felinto Lopes, Paulo Setúbal, Hilário Tácito, Raul de Freitas, Quinzinho Correia, Indalécio Aguiar, Armando Rodrigues, Júlio Cesar da Silva, Wasth Rodrigues, Roberto Moreira, Ricardo Cipicchia, Voltolino, Cornélio Pires, Sílvio Floreal, Amadeu Amaral, Simões Pinto, Cândido

\footnotetext{
${ }^{71}$ IDEM, ibidem, p. 579. Carta de Buenos Aires, 13/07/1946.

${ }^{72}$ Marisa Lajolo, Patricia Artundo e Thaís Mattos Albieri discutem aspectos da relação entre Monteiro Lobato e os argentinos.

LAJOLO, Marisa. De São Paulo ao Aconcágua: uma trajetória latino americana para Monteiro Lobato. Disponível em: http://www.unicamp.br/iel/monteirolobato/outros/limaportugues.pdf Acesso em 10 out. 2013. ARTUNDO, Patricia. “Os empreendimentos editorias de Monteiro Lobato e Manuel Gálvez”. In: Mário de Andrade e a Argentina: Um país e sua produção cultural como espaço de reflexão. São Paulo: Edusp, 2004.

ALBIERI, Thaís Mattos. São Paulo-Buenos Aires: A trajetória de Monteiro Lobato na Argentina. In: XIV SEMINÁRIO DE TESES EM ANDAMENTO, n. 3, novembro de 2008, Campinas (São Paulo). Anais do SETA, Campinas: UNICAMP, 2009, p. 913-923. Disponível em: http://tiny.cc/sax99w Acesso em: 2 out. 2013.
} 
Fontoura, Gelásio Pimenta, Oswald de Andrade, Jairo de Góis, Mário Pinto Serva, Moacir Piza, René Thiollier, Rebouças, Pinheiro Júnior, Assis Cintra, Antônio Figueiredo, Jacomino Define, Adalgiso Pereira, e ainda muitos outros, com cujos nomes não consigo atinar neste momento." ${ }^{73}$

Grande parte dos nomes citados reaparece n'A barca, como veremos mais adiante, por Lobato também compartilhar com Rangel aspectos das relações que travava socialmente.

Ao associar as várias facetas, verifica-se que Lobato é não só um leitor experiente como sabe apurar seu faro editorial, descobrindo escritores que potencialmente agradariam o público $^{74}$. Monteiro Lobato era um homem de negócios! Mas será que ele lia todos os livros que lhe apareciam? A resposta nos é dada novamente por Léo Vaz:

"Lobato examinava perfunctoriamente todos esses escritos, 'cheirava-os', como costumava dizer; e em deparando algum que lhe parecesse editorialmente aproveitável, lia-o de começo a fim, ou passava-o a algum amigo que dos méritos e possibilidades dele lhe desse parecer., ${ }^{, 75}$

Sendo assim, a lista de escritores brasileiros cujos textos teriam sido lidos por Lobato provavelmente é bem mais ampla do que se pode verificar n'A barca de Gleyre. A pesquisadora Juliana Cristina Garcia, na dissertação Monteiro Lobato: contista e editor, ${ }^{76}$ fez um levantamento dos títulos publicados pela Revista do Brasil (1918) e pelas editoras Monteiro Lobato \& Cia. (1920), Cia. Graphico-Editora Monteiro Lobato (1924) e a Cia. Editora Nacional (1926). Assim, ela rastreou 489 títulos de 284 autores, publicados ao longo dos anos em que Monteiro Lobato foi editor, com a ressalva de que esse número pode ser ampliado, dadas as dificuldades em pesquisar os catálogos das editoras ${ }^{77}$.

No COMPLEMENTO E deste trabalho, nos valemos da tabela organizada por Juliana Cristina Garcia para mostrar o quanto a relação de Lobato com outros escritores é ampla. Infelizmente, não se pode precisar quais foram de fato as obras lidas deste catálogo, porém, de algum modo, elas passaram pelas mãos do Lobato editor.

Deste modo, a tarefa de rastrear as leituras de Lobato deste período mostra-se repleta de desafios. As cartas d'A barca de Gleyre testemunham apenas parcialmente a relação com autores brasileiros. Se antes os livros eram vistos, principalmente, como espaço de formação e

\footnotetext{
${ }^{73}$ VAZ, Léo. "No jubileu do Jeca Tatu”. In: Páginas vadias. Rio de Janeiro: Livraria José Olympio Editora, 1957, p. 78-9.

${ }^{74}$ BROCA, Brito. O repórter impenitente. Campinas, São Paulo: Editora da Unicamp, 1994, p. 65-6.

${ }^{75}$ VAZ, Léo. "Lobato editor". In: Páginas vadias. Ed. cit., p. 85.

${ }^{76}$ GARCIA, Juliana Cristina. Monteiro Lobato: contista e editor. Dissertação de Mestrado (orientação: Alckmar Luiz dos Santos). Florianópolis, Santa Catarina: Universidade Federal de Santa Catarina, 2013.

${ }^{77} \mathrm{Em}$ sua tese, Cilza disponibilizou imagens dos catálogos de 1923 da Monteiro Lobato \& Cia. e de 1924 e 1925 da Cia. Graphico-Editora Monteiro Lobato. Cf. BIGNOTTO, Cilza Carla. Op. cit., cd anexo.
} 
exercício literário, neste outro contexto, a leitura assume um papel diferente. Cada vez mais o mundo literário se desmistifica para Lobato, que vê seu nome espalhar-se Brasil afora. Seu relacionamento com intelectuais mostra-se fundamental na trajetória de seus negócios. Assim, recorreu-se a este recorte para exemplificar como neste período Lobato não só leu títulos brasileiros, como atuou diretamente na produção da literatura no país. Portanto, é pouco provável que se consiga separar o leitor, do escritor, crítico e editor Monteiro Lobato, mesmo para estudar apenas uma dessas facetas, desafio que outros pesquisadores também têm enfrentado $^{78}$.

Mesmo com algumas ressalvas, é ampla e variada a lista de brasileiros que figuram ao longo dos mais de quarenta anos de cartas d'A barca de Gleyre, Afrânio Peixoto, Agenor Silveira, Agripino Grieco, Albertina Bertha, Alberto de Oliveira, Alberto Rangel, Alberto Seabra, Alberto Torres, Alfredo Pujol, Almaquio Diniz, Aluísio Azevedo, Amadeu Amaral, Antônio Álvares Pereira Coruja, Antônio de Morais Silva, Aparício Torelly (Barão de Itararé), Araripe Júnior, Arnaldo Simões Pinto, Artur Azevedo, Artur Goulart Penteado, Augusto de Lima, Augusto Freire da Silva, Belisário Pena, Bernardo da Veiga Torres, Bernardo Guimarães, Carlos de Laet, Castro Alves, Cesídio Ambrogi, Chico Xavier, Coelho Neto, Cornélio Pires, Delgado de Carvalho, Eduardo Carlos Pereira, Eduardo Prado, Emílio De Menezes, Euclides da Cunha, Fagundes Varela, Francisco de Paula Ney, Garcia Redondo, Godofredo Rangel, Galdino Pinheiro (Galpi), Graça Aranha, Guilherme de Almeida, Helio Lobo, Herman Lima, Hilário Tácito, Heitor de Morais, Ignácio da Costa Ferreira (Ferrignac), Jarbas Loretti, João do Rio, João Kopke, João Pedro da Veiga Miranda, João Pinto Da Silva, Joaquim Manuel de Macedo, Joaquim Osório Duque-Estrada, José Antônio Nogueira, José Carlos de Macedo Soares, José de Alencar, José de Freitas Valle, José Severiano de Rezende, José Soriano de Sousa, José Veríssimo, Júlio Cesar da Silva, Juó Babanéri, Júlia Lopes de Almeida, Léo Vaz, Lima Barreto, Luís Norberto de Sampaio Freire, Machado de Assis, Manuel Antônio de Almeida, Manuel Bonfim, Manuel de Oliveira Lima, Manuel de Oliveira Paiva, Manuel Francisco Pinto Pereira, Maria José Dupré, Martim Francisco Ribeiro de Andrada III, Medeiros e Albuquerque, Melo Morais Filho, Menotti Del Picchia, Olavo Bilac, Olímpio Portugal, Oliveira Viana, Oswald de Andrade, Papi Júnior, Paulo Prado, Paulo Setúbal, Raimundo Correia, Raul de Freitas, Raul Pompéia, René Thiollier, Ribeiro Couto,

\footnotetext{
${ }^{78}$ Milena Ribeiro Martins aborda aspectos da atividade de Monteiro Lobato enquanto editor das próprias obras, terminado a primeira parte de sua tese com a conclusão de que não há como separar as diferentes esferas de atuação de um literato múltiplo como Lobato.

Cf. MARTINS, Milena Ribeiro. Lobato edita Lobato: história das edições dos contos lobatianos. Tese de Doutorado (orientação Marisa Lajolo). Campinas: Unicamp, 2003, p. 130.
} 
Ricardo Gonçalves, Rocha Pombo, Rodolfo Teófilo, Ronald de Carvalho, Rui Barbosa, Sérgio Milliet, Silva Ramos, Sílvio Romero, Tristão de Athayde, Valdomiro Silveira, Vicente de Carvalho, Viriato Correia, Visconde de Taunay, Xavier da Veiga.

Embora as menções sejam muitas, é provável que Lobato não tenha tido contato com os livros de alguns desses autores. Por exemplo, tanto Ribeiro Couto como Rocha Pombo, entre outros, são citados nas páginas d'A barca apenas como companheiros, sem nenhuma referência à leitura. É preciso lembrar que, na impossibilidade de localizar os títulos lidos por Monteiro Lobato, valemo-nos de sua correspondência para recuperar vestígios de sua biblioteca.

\section{Quem tem um amigo editor? O Cenáculo tem!}

\footnotetext{
"Vou editar o Ricardo [Gonçalves] em setembro - Ipês. Já temos, paridos pelo prelo, o [José Antonio] Nogueira e eu; saindo você e o Ricardo, restará em estado interessante só o Albino [Camargo] com seu tratado de psicologia. E o Cenáculo terá vencido, hein?"
}

Monteiro Lobato ${ }^{79}$

Durante as atividades no ramo editorial, não só as amizades com jornalistas e escritores renderam a Lobato material a ser publicado. Segundo a tabela que está no COMPLEMENTO E, Godofredo Rangel, José Antônio Nogueira, Ricardo Gonçalves e Raul de Freitas, companheiros no Cenáculo, tiveram títulos lançados pelo editor entusiasta.

Sem dúvidas, dentre eles, Godofredo Rangel é o que mais se sobressai.

Se em A barca de Gleyre testemunham-se diferentes aspectos da vida e da obra de Monteiro Lobato, embora não tenhamos acesso à parcela de Rangel ${ }^{80}$, é possível reunir informações sobre este interlocutor lobatiano.

\footnotetext{
${ }^{79}$ LOBATO, Monteiro. A barca de Gleyre. Ed. cit., p. 426. Carta de São Paulo, 29/08/1918.

${ }^{80}$ Contamos apenas com os dois números especiais do Suplemento Literário do Minas Gerais, organizados por Márcio Sampaio, em 1984, no qual constam dezessete cartas de Rangel a Monteiro Lobato.
} 
Entre as leituras de Lobato, é provável que os textos de Rangel tenham sido os mais lidos, analisados e comentados. O otimismo para com a produção do amigo está presente desde a primeira carta d'A barca:

“[...]acabo de ler no Minarete ${ }^{81}$ a tua primeira joia, meu Rangel, o teu primeiro vagido literário impresso, pois que manuscritamente tens vagido muito. Não calculas como aquilo está bom, sobretudo na primeira parte. Todos, sem exceção, gostamos imenso - e foste proclamado o primus inter pares do Cenáculo. Enquanto o resto dessa cainçalha se amofina por aqui, infecunda e lorpa, só alcançando sucesso pela fúria, como o Lino ${ }^{82}$ ou com desordens, como o Bruno ${ }^{83}$, lá num socavão mineiro nosso Anjo progride desembaraçado e já apresenta contos dignos de Daudet.

"Franqueza, Rangel, invejo-te muito! Nesse andar chegarás. Quem leu os teus comecinhos n'O Combatente e agora lê o teu Vagido ${ }^{84}$, apalpa o progresso. Mas deixemos isto, porque tens a mania de modéstia e o sestro de me considerar irônico." ${ }^{.5}$

As críticas lobatianas, em grande parte colocam a produção de Rangel em destaque, o comparando até mesmo com escritores já consagrados. Ao passo que os textos agradam, a humildade do Anjo do Cenáculo é desaprovada em outras cartas, como nesta de 20 de janeiro de 1904:

"Tuas cartas me são um estimulante; obrigam-me a pensar, abrem-me perspectivas. Mas estás um homem cheio de vícios mentais e cacoetes. $\mathrm{O}$ pior é a mania (que acho irônica) de te rebaixares e me pores nas nuvens (como o Rei dos Judeus), quando na realidade não passamos, os dois, de duas 'sedes de saber', de duas 'fomes de expressão' em tudo equivalentes. Que graça, botar a minha sede acima da tua! Sede é sede. Outro vício teu é a tal modéstia. Parece que você faz da modéstia palanque donde melhor regalar-se com a vaidade humana. Seja todo portas e janelas abertas, homem!" 86

Além de amigos e correspondentes, Rangel e Lobato tornam-se leitores privilegiados, compartilhando manuscritos e análises. A carta de $1^{\circ}$ de julho de 1909 , na qual vem o julgamento de Os bem casados, é exemplar para discutir essa questão:

"Li Bem casados duma assentada - e que quer você mais? Só as novelas muito empolgantes suportam essa prova. Todos os personagens fisgados da vida; e cada um, um tipo. Dona Alípia, ótima! O Coutinho, o Licínio, todos, até a Flausina, ótimos! Só dona Ismênia me parece algo imaginada - poderá lá existir tamanha carneirice? Mas fica bem num livro de tanto realismo essa

\footnotetext{
${ }^{81}$ Jornal de Pindamonhangaba, mantido por Benjamim Pinheiro de julho de 1903 a julho de 1907.

${ }^{82}$ Lino Moreira, companheiro no Cenáculo.

${ }^{83}$ Bruno de Cádiz, pseudônimo literário de Ricardo Gonçalves, companheiro no Cenáculo.

84 "Simbólico vagido", primeiro conto de Godofredo Rangel no jornal Minarete, no qual descreve o seu próprio nascimento e o seu primeiro vagido.

${ }^{85}$ LOBATO, Monteiro. A barca de Gleyre. Ed. cit., p. 38-42. Carta de São Paulo, 09/12/1903.

${ }^{86}$ IDEM, ibidem, p. 56. Carta de Taubaté, 20/01/1904.
} 
leve fuga à realidade. É sal na melancia. Está você, portanto, doutorado em romance! Falta apenas um pouco de focalização e o polimento final. Há umas coisas fora de foco. [...]

"Se você gastou dois meses no borrão dos Bem casados, leve dois anos no polimento." 87

N'A barca, o romance rangeliano é referido a partir do ano de 1908, possivelmente reclamado por Rangel: "Queres Os bem casados? Ainda não pude meter ali o bedelho." ${ }^{, 8}$ Lobato, o magister do Cenáculo, epíteto que os amigos e o próprio escritor chegou a utilizar ${ }^{89}$, acredita no valor literário de Rangel. Nas críticas, prevalece o tom elogioso, mesmo indicando pontos a serem aprimorados: "Não tenha pressa em publicar-se. Olhe os bons exemplos. Não digo o Flaubert, que aquilo também era demais - pura doença; mas os outros limpos." Ao que parece, Rangel considera a opinião de Lobato, mas continua trabalhando "flaubertianamente" em Os bem casados, publicado apenas postumamente em 1955.

Através da análise do conjunto epistolar d'A barca de Gleyre, pode-se concluir que ambos se beneficiaram das trocas epistolares: sugerem e discutem leituras, apontam caminhos literários, adotam, como parte do processo de criação, as sugestões e as críticas um do outro sobre as diversas versões de seus textos. Logo, essas leituras e a gênese compartilhada assumem importante papel na formação literária tanto de Lobato como de Rangel.

Felizmente, para conhecer um pouco mais sobre as trocas entre os dois missivistas, tivemos acesso aos dois números especiais do Suplemento Literário do Minas Gerais, organizados por Márcio Sampaio em 1984. Lograram trazer cartas de Rangel que, em 1910, escreve a Lobato:

\footnotetext{
"Dei-me um mês de férias para me refazer da fadiga dos Bem casados. Estou como se estivesse vindo de uma longa viagem de dois meses sem tréguas: e é estremunhado que estudo autos em atraso e releio a jornalada amontoada: ao mesmo tempo, com alvoroço contente de estudante que passou no exame, recomeço o português, prosseguindo na quarta leitura dos Lusíadas e relendo o D. Quixote do Jornal do Brasil, com dois volumes do Anatole à espera.
}

"Recomeçar a escrever-te é um prêmio que me concedi.

"Quando digo que passei em exames, não elogio com isso meu manuscrito: nem tão pouco o detraio, pois sobre ele não tenho juízo: bem como uma parreira não sabe dizer se são boas ou más os cachos que produz. Espero tua apreciação para ver claro: e depois do mês de espairecimento,

\footnotetext{
${ }^{87}$ IDEM, ibidem, p. 201-2. Carta de Areias, 01/07/1909.

${ }^{88}$ IDEM, ibidem, p. 188. Carta de Areias, 10/12/1908.

${ }^{89}$ IDEM, ibidem, p. 55 e 60.
} 
vou operar a refusão do oito, caso o aproves, ou começar o $n^{\circ} 13$, se o condenares. [...]

"Penitencio-me de uma frase que lá ficou atrás armando efeito: como uma parreira etc. Quero dizer que me sinto confuso para dizer se o livro é bom ou mau, oscilando entre estes dois juízos."

Aqui ficam registradas matrizes do processo de criação da obra de Rangel, as quais nos fazem pensar nas diversas fases pelas quais pode passar um texto até sua publicação, inclusive os intervalos de tempo diante do manuscrito. Por meio da comparação com a parreira, são aludidos o próprio fazer literário e as inerentes dificuldades da escrita. Outra característica da produção literária de Rangel que passa a ser conhecida é a numeração dos textos.

Nota-se também que n'A barca há diversas passagens em que Lobato comenta o livro Vida ociosa, de modo que se pode acompanhar a construção do texto até a publicação, em 1920, pela editora Monteiro Lobato \& Cia. Após diversos pedidos para que Rangel publicasse seus livros, o editor se entusiasma:

\begin{abstract}
"Ora até que enfim resolves soltar a Vida ociosa! Vais ver o sucesso. Antes, porém, de tratar comercialmente a coisa, vou explicar-te onde estamos e ao que vamos. [...] Ora, tudo isto para te dizer que podemos lançar também lá [na Argentina] a tua Vida ociosa. Ao mesmo tempo aqui e em Buenos Aires. E este fato forçará aqui a atenção do público. Que tal? Manda-me os originais definitivos para calcularmos o custo da edição e fazermos proposta. Estou ansioso por te ver no giro." $" 11$
\end{abstract}

Lobato é eficiente no preparo da edição de Vida ociosa. Outras cartas testemunham os comentários críticos, as alterações e as sugestões ao amigo. Lobato não só lê o texto como sugere cortes e títulos de capítulos; revisa a ortografia e encomenda o prefácio a Hilário Tácito. Mesmo próximo à publicação, o leitor-editor opina até mesmo sobre o desfecho do romance e no título dos capítulos:

\footnotetext{
"Queria pregar-te uma surpresa: dar a Vida ociosa pronta quando menos esperasses. Mas o sentimentalismo entrou em conflito com o utilitarismo - e lá vão as provas para o teu repasse final. Falha a surpresa, mas escapas ao perigo de erros por descuido aqui. Creio que entre nós não é preciso contrato. Tudo meio a meio, como já combinamos. Mas é forçoso que cortes aquele final com que toda gente - e com carradas de razão - se implica." ${ }^{92}$
}

\footnotetext{
${ }^{90}$ Carta de Godofredo Rangel a Monteiro Lobato. In: Suplemento Literário do Minas Gerais, Belo Horizonte, ano 19 , n. $948,1^{\circ}$ dez. 1984, p. 9. Transcrição da carta de 06/a?/1910.

${ }^{91}$ LOBATO, Monteiro. A barca de Gleyre. Ed. cit., p. 443. Carta de São Paulo, 06/07/1919.

${ }^{92}$ IDEM, ibidem, p. 455. Carta de São Paulo, 04/08/1920.
} 
"Vieram as provas. Mandarei segundas. Dos dois títulos, melhor o velho. Bonança! Desenxabido demais. Molenga. Vê se achas coisa mais forte, mais sugestiva." 93

O diálogo entre as cartas n'A barca de Gleyre e as transcritas no Suplemento Literário reitera a relação entre a crítica genética e o gênero epistolar, perspectiva esta pela qual, segundo Marcos Antonio de Moraes, a correspondência é vista como arquivo da criação, isto é: "espaço onde se encontram fixadas a gênese e as diversas etapas de elaboração de uma obra artística, desde o embrião do projeto até o debate sobre a recepção crítica favorecendo a sua eventual reelaboração." 94

O que caracteriza um editor de sucesso? Em se tratando de Lobato, observa-se através d'A barca como seu nome vai se inserindo nos meios intelectuais brasileiros. Anos antes, o livro Canaã é discutido em carta com Rangel; já como editor, em 1921, Lobato é procurado por Graça Aranha e, curiosamente, conversam sobre Vida ociosa:

"Esteve por aqui o Graça Aranha. Foi interessante o nosso encontro. O Jacinto, daquela livrariazinha $\mathrm{O}$ Livro, telefonou-me dois dias seguidos. Primeiro dia: 'O Graça Aranha está em São Paulo e quer conhecê-lo'. Fiquei ciente e agradeci. Segundo dia: 'O Graça Aranha quer conhecê-lo. Venha cá'. Respondi: 'Não posso. Muito serviço. Se de fato ele quer me conhecer, que venha procurar-me aqui'. Sim, porque quando eu quero conhecer alguém, eu o procuro, não o mando chamar sob vara. E afinal o Graça Aranha veio ontem e conversamos longamente e ficamos amigos. Falou tão bem da Vida ociosa que me entrou no coração. Eu hoje avalio os homens pela capacidade de compreensão do teu livro. Amanhã vamos almoçar juntos. $^{95}$

Mais uma vez, vê-se o quanto a rede de sociabilidade de Lobato contribui em sua atividade editorial e mostra um pouco mais sobre os bastidores da vida literária da época.

Infelizmente, não há registros como estes que tragam mais de perto o Lobato leitor de seus outros amigos do Cenáculo, José Antonio Nogueira, Raul de Freitas e Ricardo Gonçalves.

\footnotetext{
${ }^{93}$ IDEM, ibidem, p. 455. Carta de São Paulo, 30/08/1920.

${ }^{94}$ MORAES, Marcos Antonio de. Epistolografia e Crítica Genética. Ciência e Cultura, São Paulo , v. 59, n.1, Jan./Mar. 2007. Disponível em: http://cienciaecultura.bvs.br/scielo.php?pid=S000967252007000100015\&script=sci_arttext. Acesso em: 10 jan. 2012.

${ }^{95}$ LOBATO, Monteiro. A barca de Gleyre. Ed. cit., p. 471. Carta de São Paulo, 27/10/1921.
} 


\title{
Capítulo 4
}

\section{Um Lobato e muitas literaturas}

\begin{abstract}
"Há muitas maneiras de ler. Talvez que a mais profunda seja a de quem verte um livro para outra língua. O tradutor é um escafandrista. Mergulha na obra como num mar; impregna-se dum pensamento concretizado de um certo modo - o estilo do autor - e lentamente o vai moldando no barro de outro idioma, para que a obra não admita fronteiras. Sem esses abnegados trabalhadores, a literatura ficaria adstrita a pátrias, condenada a limites muito mais estreitos do que os permitidos pela sua potencialidade."
\end{abstract}

(Monteiro Lobato $)^{1}$

Como conciliar os ideais para a afirmação de uma arte de cunho nacional e, ao mesmo tempo, ser um mediador da literatura estrangeira? A pluralidade que marca a trajetória de Monteiro Lobato revela o quanto ele se empenhou em diferentes atividades e, de alguma maneira, as relacionou entre elas. Não se pode negar que o Lobato tradutor também dialoga com seu(s) perfil(is) de leitor estudado(s) ao longo desta dissertação. Por meio da metáfora do escafandrista, mostra que para ele o trabalho de traduzir é acompanhado de intensas leituras. É como leitor privilegiado que mergulha na obra de outrem, com a missão de trazer para a língua de seu povo o texto. Logo, o abnegado artífice, ao mesmo tempo, lê e (re)cria.

Novamente, a tarefa de ler adquire outro significado para Monteiro Lobato - o ganha pão. Ainda mais se pensarmos no livro enquanto mercadoria, pois, tanto para o tradutor quanto para o editor que ele também foi, a leitura significou possibilidades financeiras. N'A barca de Gleyre, em carta de $1^{\circ}$ de julho de 1909 , época em que residia na cidade de Areias como promotor público, está o registro do início desse seu trabalho:

"Tenho mandado uns artigos para A Tribuna de Santos e publicado n' $O$ Estado de S. Paulo umas traduções do Weekly Times - esse meu meio de neutralizar Areias. Leio o Times em Areias! Informo-me todas as semanas da saúde de Her Majesty. Quando encontro coisas muito interessantes, traduzoas e mando-as para o Estado e eles me pagam 10 mil-réis. Acho estranho isto de ganhar um dinheiro qualquer com o que nos sai da cabeça. Vender pensamentos próprios ou alheios... Mas não tolero escrever por obrigação, traduzo quando quero. Faço coisas para A Tribuna quando quero. Do contrário, sentir-me ia escravo no eito." ${ }^{2}$

Como válvula de escape na pequena cidade interiorana, Lobato assina The Weekly Times, fato este que permite retomar a ideia de auto-exílio defendida por Tadeu Chiarelli, em Um Jeca nos vernissages. Já para Marisa Lajolo, a carta reforçaria o bom humor lobatiano

\footnotetext{
${ }^{1}$ LOBATO, Monteiro. "Eu tomo o sol...”. In: Conferências, artigos e crônicas. Edição coordenada por Cecília Bassarani. São Paulo: Globo, 2010, p. 174.

${ }^{2}$ IDEM. A barca de Gleyre. Ed. cit., p. 202-3. Carta de Areias, 01/07/1909.
} 
frente ao contraste do meio interiorano com o mundo que lhe chega pelo jornal inglês. Aliás, o ambiente de Areias, na obra ficcional do escritor apoia a metáfora Cidades mortas, no título do seu segundo livro de $\operatorname{contos}^{3}$. Mas ele já tratara da presença de números das revistas The Strand e Wide World Magazine em suas estantes desde $1906^{4}$. O hebdomadário londrino entra na chave do envolvimento do carteador com as leituras em língua inglesa; também expressado a Rangel em 2 de dezembro de 1908. O que Lobato aprecia em The Weekly Times é justamente a ampliação do mundo que lhe dá as notícias dos ingleses. Estende a admiração ao julgar a literatura inglesa, em especial Kipling:

"Para neutralizar esta Areias sem apito tomei uma assinatura do Weekly
Times, de Londres - edição semanal em que vêm os melhores artigos do The
Times diário, o grande, o velho, o tremendo Times de Londres - e com os
pés na grade da sacada injeto-me de inglês, de pensamento inglês, de política
inglesa, enquanto pela rua passam os bípedes que vão mexer a panelinha da
política local na farmácia do Quindó, meu vizinho. E tenho lido
exclusivamente em inglês. O francês anda a me engulhar todas as tripas.
Como cansa aquela eterna historinha dum homem que pegou a mulher do
outro - como se a vida fosse só, só, só isso! A literatura inglesa é muito mais
arejada, variada, mais cheia de horizontes, árvores e bichos. Não há tigres
nem elefantes na literatura francesa, e a inglesa é toda uma arca de Noé. Só
em Kipling há material para um tremendo jardim zoológico: Kaa, Bagheera,
Shere Khan, a macacada... E há focas e pinguins."

Não só a língua portuguesa passou a interessar Lobato nessa época; a leitura em inglês aos poucos sedimenta o contista e prepara o futuro tradutor. Rudyard Kipling (1865-1936), ao lado do francês Guy de Maupassant, apesar das certas críticas do leitor à literatura francesa, podem ser considerados referenciais na formação deste grande contista brasileiro, como destacamos no segundo capítulo desta dissertação. Cabe uma parada em Kipling, matriz desse Monteiro Lobato e obra que tradutor expandirá em nosso país.

No período 1904-1941, dezenove cartas mencionam o criador de The Jungle Book, que o contista de "Negrinha" toma como mestre, ou matriz, em 1909:

\footnotetext{
${ }^{3}$ LAJOLO, Marisa. A presença do jornal na vida e na obra de Monteiro Lobato. In: Congresso Brasileiro de Marketing Político - POLITICOM. Memória, espaço e mídia. São Paulo: Editora da Universidade Metodista de São Paulo, UMESP/Mackenzie, $2010 . \quad$ Disponível em: http://www.rehime.com.ar/escritos/documentos/idexalfa/q/queiroz/Quieroz\%20-\%20Schaun\%20\%20Memoria\%20Espaco\%20e\%20midia.pdf. Acesso em: 04 nov. 2013.

${ }^{4}$ LOBATO, Monteiro. A barca de Gleyre. Ed. cit., p. 105. Carta de Taubaté, 15/03/1906.

${ }^{5}$ IDEM, ibidem, p. 187. Carta de Areias, 02/12/1908.
} 
"Tenho examinado os últimos livros de contos aparecidos. Nada como quero. [...] O nosso livro de contos será o contrário disso. Todo cheio de novidades, na forma e no entrecho. E nada de amorécos e adulteriosinhos de Paris. Isso já fede. Será como os de Kipling - com paisagens, árvores, céu, passarinhos, negros..."6

Não só a preferência pelo gênero aproxima Lobato e Kipling. O conto "Os faroleiros", publicado no vigésimo número da Revista do Brasil, em agosto de 1917, e posteriormente inserido no livro Urupês, é exemplar para se apontar o diálogo entre leitura e escrita literária: “Minha 'Cavaleria rusticana', que vou mudar para 'Os faroleiros' porque toda gente confunde 'cavaleria' com 'cavalaria' (que cavalo!), é uma colcha de retalhos cosida com panos de diversas épocas e de várias qualidades - linho, algodão, estopa."7 De 1909 a 1917, Lobato, ao trabalhar sua narrativa cujo espaço é o farol, dentre os muitos "panos"/ matrizes a que se liga, tem Kipling referenciado desde as primeiras páginas da narrativa:

"- Uma leitura de Kipling despertara-me a curiosidade de conhecer um farol por dentro.

“_ 'O perturbador do tráfego'...

“- Parabéns pela argúcia. Foi justamente a história do Dowse o ponto inicial do meu drama. Esse desejo incubou-se-me cá dentro à espera da ocasião para brotar." 8

Logo se percebe o diálogo entre "Os faroleiros" e "The Disturber of Traffic", da obra Many Inventions (1893), de Rudyard Kipling. Tanto a escolha do espaço da trama quanto o tema solidão no farol apontam interlocuções. O conto lobatiano também traz referências a Schopenhauer, Shakespeare, Ibsen, Gustave Doré e à Cavalleria Rusticana, ópera de Pietro Mascagni ${ }^{9}$.

Além de se apropriar de Kipling, Lobato traduz-lhe o conto "A Matter of Fact", também de Many Inventions, como relata a Rangel na mesma carta de 27 de junho, 1909:

\footnotetext{
${ }^{6}$ IDEM, ibidem, p. 198. Carta de Areias, 27/06/1909.

${ }^{7}$ IDEM, ibidem, p. 410. Carta de Caçapava, 11/10/1917.

${ }^{8}$ IDEM. Urupês. Edição coordenada por Arlete Alonso. São Paulo: Globo, 2007, p. 23.

${ }^{9}$ Outras relações dialógicas entre Lobato e Kipling são analisadas em BECKER, Elizamari Rodrigues. Forças motrizes de uma contística pré-modernista: o papel da tradução na obra ficcional de Monteiro Lobato. Tese de Doutorado (orientação: Patrícia Lessa Flores da Cunha). Porto Alegre: Instituto de Letras, Universidade Federal do Rio Grande do Sul, 2006.
} 
"Já leste A mais bela história do mundo? Impossível novela mais rica de horizontes. Do mesmo grande Kipling traduzi para o Minarete o conto 'Um fato'. Prodigioso. História duma serpente do mar que em consequência duma erupção vulcânica submarina rebentou lá no fundo e veio à tona, escabujando no desespero da 'falta de pressão atmosférica', espécie de falta de ar. [...] Não pode haver pintura mais fiel, mais d'après nature, dessa serpente marinha que Kipling viu escabujar moribunda - que ele viu, apesar da serpente do mar ser apenas uma crendice de marinheiro!" 10

O contista em formação mostra-se encantado com a técnica narrativa de Kipling. Aliás, em 1907, o Nobel de Literatura laureava Kipling, primeiro autor de língua inglesa a receber esse prêmio e, até hoje, o mais jovem, justamente "in consideration of the power of observation, originality of imagination, virility of ideas and remarkable talent for narration which characterize the creations of this world-famous author". 11

Segundo Edgard Cavalheiro, Lobato leu a obra completa de Kipling e publicou, pela Companhia Editora Nacional, suas traduções: Mowgli, o menino lobo ${ }^{12}$, Jacala, o crocodilo, O livro da Jângal (The Jungle Book e The Second Jungle Book), em parceria com J. Almansur Haddad, e Kim (Kim). Cabe mencionar que, em 1934, a mesma editora imprimira a tradução de Kim por Batista Pereira, feita da edição francesa. Monteiro Lobato traduz do original em inglês, trabalho este realizado em 1941, durante os três meses em que esteve preso, por ordem da ditadura de Vargas. É preciso reconhecer o pioneirismo de Lobato ao traduzir diretamente da língua inglesa, uma vez que os títulos ingleses que circulavam no Brasil desta época eram lidos no original ou vertidos do francês ${ }^{13}$.

Elizamari Rodrigues Becker acredita que não só Kipling tenha contribuído para a produção lobatiana. Enquanto difusor da literatura estrangeira, o Lobato editor e tradutor possibilitou a circulação de muitos escritores no Brasil, sobretudo Kipling:

\footnotetext{
${ }^{10}$ LOBATO, Monteiro. A barca de Gleyre. Ed. cit., Carta de Areias, 27/06/1909.

${ }^{11}$ Disponível em: http://www.nobelprize.org/nobel_prizes/literature/laureates/1907/. Acesso em: 01 nov. 2013.

${ }^{12}$ Três histórias em The Jungle Book e cinco em The Second Jungle Book referem-se ao personagem Mowgli. Por razões de percepção comercial, Monteiro Lobato resolveu editar todas as histórias de Mowgli num único volume da coleção Terramarear: Mowgli, o menino-lobo. Os demais contos dos Jungles Books foram reunidos por Lobato na coleção Jacala, o crocodilo (referência ao conto The Undertakers). Cf. ROCHA, Pedro Albeirice da. Relembrando Kipling: notas sobre os Jungles Books e o romance Kim. Anthesis: Revista de Letras e Educação da Amazônia Sul-Ocidental. v. 01, p. 225- 236, n01. Cruzeiro do Sul, Acre: Universidade Federal do Acre, 2012. Disponível em: http://www.periodicoseletronicos.com.br/index.php/anthesis/article/view/66/56. Acesso em: 04 nov. 2013.

${ }^{13}$ BECKER, Elizamari Rodrigues. Op. cit., p. 86.
} 
"Se há quem veja débito na influência de um autor sobre outro, ou da tradução em relação ao original, torna-se difícil dizer quem deve mais a quem, se Lobato a Kipling, pela impregnação criadora que muito repercutiu na própria criação literária deste brasileiro, bem como em seu projeto de criação de um público ledor de massa, que consome livros e boas traduções, ou Kipling a Lobato, por torná-lo parte do cânone para o público leitor brasileiro, com suas feras e sua selva." $" 14$

No acervo da Biblioteca Infantil Monteiro Lobato e no Fundo Monteiro Lobato CEDAE/IEL/UNICAMP não foram localizadas obras de Kipling; apenas as traduções lobatianas Mowgli, o menino lobo, Jacala, o crocodilo, O livro da Jângal e Kim, ali figuram.

Se, em matéria de contos, Lobato queria os seus como os de Kipling e Maupassant, é a ficção científica de H.G. Wells (1866-1946) que desperta, no ainda jovem escritor brasileiro, a ambição de um caminho literário a seguir:

“[...] Ando com ideias dumas coisas à Wells, em que entrem imaginação, a fantasia possível e vislumbres do futuro - não o futuro próximo de Júlio Verne, futurinho de cinquenta anos, mas um futuro de mil anos. Vou semear agora essas ideias e deixá-las se desenvolverem livremente por dez ou vinte anos - e então limito-me a fazer a colheita, caso a plantação subsista até lá. Se a terra dos meus canteiros mentais não for propícia a essas sementinhas, então é que não estou destinado a ser o H.G. Wells de Taubaté, e paciência. Ou dou um dia coisa que preste, que esborrache o indígena, ou não dou coisa nenhuma." 15

O excerto da carta de 17 de dezembro de 1905 mostra um Lobato interessado em experimentar a ficção científica. Entretanto, apenas em 8 de julho de 1926, o missivista volta ao assunto e aponta a sua relação com H.G. Wells: "Sabe o que ando gestando? Uma ideiamãe! Um romance americano, isto é, editável nos Estados Unidos. Já comecei e caminha depressa. Meio à Wells, com visão do futuro." ${ }^{\prime 16}$ Ainda em 1926, Lobato consegue lançar $O$ choque das raças ou $O$ presidente negro, romance que, segundo Emerson Tin, teve como fonte The Time Machine, de H.G. Wells ${ }^{17}$.

Infelizmente, assim como ocorre com os livros de Kipling, tanto no acervo da Biblioteca Infantil Monteiro Lobato como no Fundo Monteiro Lobato CEDAE/IEL/UNICAMP não se localizou qualquer exemplar da obra de Wells que tenha pertencido ao escritor, apenas duas traduções do próprio Lobato: A ilha das almas selvagens

\footnotetext{
${ }^{14}$ IDEM, ibidem, p. 91.

${ }^{15}$ LOBATO, Monteiro. A barca de Gleyre. Ed. cit., p. 100. Carta de Taubaté, 17/12/1905.

${ }^{16}$ IDEM, ibidem, p. 514. Carta do Rio de Janeiro, 08/07/1926.

${ }^{17}$ TIN, Emerson. Ficção científica no Brasil: O choque das raças ou O presidente negro, de Monteiro Lobato. Remate de Males. v. 32, $\mathrm{n}^{\mathrm{o}}$ 2, p 293-305. .Campinas/ São Paulo: UNICAMP, jul./dez. 2012. Disponível em: http://www.iel.unicamp.br/revista/index.php/remate/article/view/3401/3400. Acesso em: 12 jan. 2014.
} 
(The Island of Dr. Moreau) e $O$ destino da espécie humana (The Fate of Homo Sapiens) ${ }^{18}$. Outros títulos por ele traduzidos nas décadas de 1930 e 1940 foram O homem invisível (The Invisible Man), História do futuro (The Shape of Things to Come) e A construção do mundo: o trabalho, a riqueza e a felicidade do mundo (The Work, Wealth and Happiness of Mankind).

Vale notar que Lobato assume as atividades de tradutor ao regressar dos Estados Unidos, onde reside no período 1927-1931. Antes disso, ocupara-se com poucos títulos: de Nietzsche, O crepúsculo dos ídolos (Götzen-Dämmerung oder Wie man mit dem Hammer philosophirt) e $O$ anticristo (Der Antichrist), a partir da versão francesa de Henri Albert; alguns contos de Kipling, entre eles, "Um fato" ("A Matter of Fact”); Minha vida e minha obra (My Life and Work) e Hoje e amanhã (Today and Tomorrow), de Henry Ford; as versões livres da História de uma viagem à terra do Brasil (Histoire d'un voyage fait en la terre du Brésil: autrement dite Amérique), de Jean de Léry, e Meu cativeiro entre os selvagens do Brasil e Aventuras de Hans Staden (contadas por Dona Benta), de Hans Staden, provavelmente feitas a partir da tradução de Alberto Löfgren, intitulada Hans Staden. Suas viagens e cativeiro entre os selvagens do Brasil $^{19}$. O COMPLEMENTO F, nesta dissertação, traz uma tabela dos livros traduzidos por Lobato, a partir de dados na biografia Monteiro Lobato: vida e obra, por Edgar Cavalheiro, e na tese Viagens de Gulliver ao Brasil (Estudo das adaptações de Gullivers's Travels por Carlos Jansen e por Monteiro Lobato), de Adriana Silene Vieira ${ }^{20}$.

Nas páginas d'A barca de Gleyre nos deparamos com referências a escritores de diferentes literaturas: brasileiros, franceses, portugueses, alemães, ingleses, russos, italianos, americanos, gregos... cada um tem seu espaço no repertório lobatiano. No Fundo Monteiro Lobato da Unicamp, localizamos obras nos idiomas inglês, espanhol e francês, além, é claro, dos textos em língua portuguesa.

\footnotetext{
${ }^{18}$ WELLS, H. G. A ilha das almas selvagens. Tradução de Monteiro Lobato. São Paulo: Cia. Editora Nacional, 1935. Localização no Acervo Monteiro Lobato, Biblioteca Infantil Monteiro Lobato: CDD 823.91.

IDEM. O destino da espécie humana. Tradução de Monteiro Lobato. São Paulo: Cia. Editora Nacional, 1941. Localização no acervo CEDAE/IEL/UNICAMP: código MLb 800013.

${ }^{19}$ NEUSS, Vanete Dutra Santana. Se os leões fossem escultores... na visão de Monteiro Lobato. Sínteses. v. 13, p. 248-275. Campinas, São Paulo: UNICAMP, 2008. Disponível em: http://www.iel.unicamp.br/ojs234/index.php/sinteses/article/view/834/587. Acesso em: 12 jan. 2014.

${ }^{20}$ CAVALHEIRO, Edgard. Monteiro Lobato: vida e obra. São Paulo: Cia Editora Nacional, 1955, p. 761-3.

VIEIRA, Adriana Silene. Viagens de Gulliver ao Brasil (Estudo das adaptações de Gullivers's Travels por Carlos Jansen e por Monteiro Lobato). Tese de Doutorado (orientação: Marisa Philbert Lajolo). Campinas, São Paulo: IEL/UNICAMP, 2004, p. 197-206.
} 
Essa pluralidade literária pode ser verificada em diversas cartas. Escolhemos a de 31 de agosto de 1907 por reunir uma síntese da opinião de Lobato:

"Em Areias - cheguei ontem - reenceto a velha prosa, mas faço-o enervado por um livro de gênio, o Crime e castigo de Dostoiéwsky. Que coisa grande e informe é a literatura russa! [...]

"A França é um velho jardim clássico. A Inglaterra é um gramado lindo. A Alemanha é uma horta científica, adubada com pós químicos, bostas sintéticas, urinas duma Werke. A Rússia é a Grande Esterqueira onde fermenta o Futuro - os futuros valores, os futuros pensamentos, os futuros moldes sociais, as futuras normas de tudo. Toda a literatura russa me dá a impressão disso. Creio que é um dos livros de Turguêniev que termina falando simbolicamente na terra negra... É isso. A Rússia é a Terra Negra da Humanidade...

"Não te posso dizer nada sobre Crime e castigo porque não há falar de coisas grandes com meios pequenos - com estas pulgas glóticas que são as 'palavras em língua portuguesa', esse produtinho lá de Portugal, onde também fazem tamancos e palitos. A nossa análise está aparelhada com medidas francesas, decimais - um sistemazinho decimal de ideias. Não pode, pois, não tem jeito, não consegue dar ideia das coisas russas. Quando leio as outras literaturas, eu sinto isto e aquilo - sentimentos analisáveis e classificáveis. Quando leio os russos, eu pressinto. Guerra e paz!... Crime e castigo! - Casa dos mortos! - Gorki - Gógol - Turguêniev - todos..." ${ }^{21}$

Embora Lobato admire os escritores russos, n'A barca não achamos tantas alusões a essa literatura, principalmente se comparadas às referências a expressões literárias de outros países. É preciso destacar que não passam desapercebidas as menções a outras literaturas, que motivaram estudos como o da pesquisadora Raquel Nunes Endalécio sobre a relação de Lobato com escritores gregos, o de Ana Luiza Reis Bedê que focalizou a presença da França nas cartas e o de Lucila Bassan Zorzato sobre as referências alemãs ${ }^{22}$.

E por falar nos germanos, é necessário fazer um parêntese sobre a filosofia de Nietzsche, que muito encantou Lobato, inclusive na sua formação de escritor. Ele assim se manifesta sobre o filósofo: "Considero Nietzsche o maior gênio da filosofia moderna - e o

\footnotetext{
${ }^{21}$ LOBATO, Monteiro. A barca de Gleyre. Ed. cit., p. 161-2. Carta de Areias, 31/08/1907.

${ }^{22}$ ENDALÉCIO, Raquel Nunes. A (re) Construção do mundo clássico na obra de Monteiro Lobato: fontes e procedimentos. Dissertação de Mestrado (orientação: Marcos Antonio de Moraes). São Paulo, Instituto de Estudos Brasileiros, Universidade de São Paulo, 2013.

BEDÊ, Ana Luiza Reis. Monteiro Lobato e a presença francesa em A barca de Gleyre. Dissertação de Mestrado (orientação: Gilberto Passos). São Paulo: Faculdade de Filosofia, Letras e Ciências Humanas, Universidade de São Paulo, 2004.

ZORZATO, Lucila Bassan. A Alemanha de Lobato. In: Anais da X Semana de Letras. 70 anos: A FALE FALA. Porto Alegre: EDIPUCRS, 2010. Disponível em: http://ebooks.pucrs.br/edipucrs/anais/Xsemanadeletras/. Acesso em: 10 set. 2013.
} 
que vai exercer maior influência. É o homem 'objetivo'. O homem impessoal, destacado de si e do mundo. Um ponto fixo acima da humanidade." ${ }^{23}$.

Após ler textos de Le Bon, Spencer e Comte, Lobato encomenda títulos na tradução francesa e mergulha em Nietzsche, a maior bebedeira de sua vida ${ }^{24}$. Confessa que o aforismo do filósofo “Queres seguir-me? Segue-te!", citado na carta de 3 de outubro de 1917, o haviam libertado de uma crise emocional aos dezoito anos:

"Essas palavras foram tudo - foram o meu remédio certo. Marcaram o fim de minha crise mental. Normalizaram-me. Entregaram-me a mim mesmo. $\mathrm{O}$ que naquela ânsia através das filosofias eu procurava era eu mesmo - e só Nietzsche contou que era assim. Em vez de seguir a alguém, ia seguir a vaga intuição do meu eu...."25

Ao contrário do que se pode pensar, nosso escritor não leu a obra toda de Nietzsche e justifica que foi por medo de assimilá-lo demais e tornar-se nietzschiano, o que contrariaria o seu "vade tecum". Há cartas em que Lobato utiliza o neologismo "lobatizar" e "rangelizar" para designar a busca de um estilo próprio, empreendida tanto por ele como por Rangel, vestígio este da filosofia de Nietzsche em sua formacão - “a função desse filósofo em minha vida foi sempre devolver-me a mim mesmo."26

Enfim, a relação de Lobato com outras literaturas amplia-se na medida em que, de leitor, torna-se um difusor de livros estrangeiros, seja por meio de suas traduções ou de novas edições durante a época em que é editor. Do diálogo entre os diversos perfis lobatianos, leitor, escritor, editor, tradutor e adaptador, algumas indagações devem ser consideradas: Quanto as traduções contribuíram na produção literária do escritor Monteiro Lobato? Ou ainda, quanto Lobato deixou de sua escrita nos textos em que traduziu? Como essa questão se relaciona com um estudo como este? A resposta nos é dada pela pesquisadora Elizamari Rodrigues Becker:

\footnotetext{
"O tradutor é, sem sombra de dúvida, um leitor muito especial, principalmente quando se trata de um tradutor que é também escritor. Se toda escritura é produto de prévias leituras, como não se ver delinear na produção literária desse tradutor-escritor os textos que dissecou com seu bisturi afiado, que experimentou em seu laboratório em fórmulas de diferentes concentrações?",27
}

\footnotetext{
${ }^{23}$ LOBATO, Monteiro. A barca de Gleyre. Ed. cit., p.66. Carta de São Paulo, 24/08/1904

${ }^{24}$ IDEM. "Confissões ingênuas". In: Conferências, artigos e crônicas. Ed. cit., p. 163.

${ }^{25}$ IDEM, ibidem, p. 163.

${ }^{26}$ IDEM, ibidem, p. 164.

${ }^{27}$ BECKER, Elizamari Rodrigues. Op. cit., p. 70.
} 
Lobato acredita que o tradutor deve ser, além de profundo leitor de outros autores, criador/escritor na língua do seu país, como define o ofício, na carta a Diaulas Riedel, em 1945:

"A tradução de fidelidade literal, isto é, de fidelidade à forma literária em que, dentro da sua língua, o autor expressou o seu pensamento, trai e mata a obra traduzida. $\mathrm{O}$ bom tradutor deve dizer exatamente a mesma coisa que o autor diz, mas dentro da sua língua, dentro da sua forma literária; só assim estará realmente traduzindo o que importa: a ideia, o pensamento do autor. Quem procura traduzir a forma do autor não faz tradução - faz uma horrível coisa chamada transliteração, e torna-se ininteligível.",28

Não pretendemos discutir aspectos dos Estudos da Tradução, limites entre certo e errado, fiel ou livre. Para Edgard Cavalheiro, Lobato conferiu novo prestígio à tradução, uma vez que escritores que o antecederam nessa atividade, como Machado de Assis, Olavo Bilac, Coelho Neto, João do Rio, traduziam esporadicamente. Assim ocorria porque, além do espaço editorial não comportar ainda o profissional, nenhum outro teria se valido da tradução como meio de vida ${ }^{29}$.

O número de traduções assinadas por Monteiro Lobato é grande e alguns chegaram até a duvidar desse ritmo acelerado, fato este que o indignava. Cavalheiro relata que, durante anos a fio, o programa de Lobato era levantar-se com o leiteiro, sentar-se à máquina e traduzir vinte páginas diariamente, inclusive domingos e feriados. Parece que, com a mesma velocidade em que ele lia, conforme declarações encontradas nas cartas, também se dedicava às traduções.

A relação de Lobato com os autores que traduz, a apropriação, bem como as (re)leituras, traduções e adaptações merecem ainda outras pesquisas.

\footnotetext{
${ }^{28}$ LOBATO, Monteiro. Cartas escolhidas. $2^{\circ}$ tomo. São Paulo: Brasiliense, 1959, p. 148. Carta escrita em 1945 para Diaulas Riedel, diretor da editora O Pensamento.

${ }^{29}$ CAVALHEIRO, Edgard. Op. cit., p. 234.
} 


\section{$\underline{\text { O famoso escritor para crianças }}$}

"A tradução tem que ser um transplante. O tradutor necessita compreender a fundo a obra e o autor, e reescrevê-la em português como quem ouve uma história e depois a conta com palavras suas.

"Ora isto exige que o tradutor seja também escritor - e escritor decente."

(Monteiro Lobato) $^{30}$

Em suas traduções, Lobato se preocupou com o público adulto, para o qual verteu uma série de livros de outras literaturas e até mesmo atualizou/adaptou obras em língua portuguesa; entre elas, Memórias de um sargento de milícias, de Manuel Antônio de Almeida, e Saudades, de Bernardim Ribeiro. Quanto ao último, Lobato vale-se da percepção de sua dificuldade linguística enquanto leitor da novela portuguesa e, como adaptador, atualiza o livro, tornando-o mais próximo ao português do Brasil, conforme revela a Rangel:

"Já concluí a semidesarcaização do Bernardim Ribeiro, mas coisa tão leve que o leitor nem sente. Nada se perdeu da ingenuidade daquele homem. De ilegível que era, ficou delicioso de ler-se. Fiz a experiência ontem em casa, com as provas. Purezinha, sempre tão exigente, leu-o e com encanto. Só agora, Rangel, vai o Bernardim popularizar-se no Brasil. Antes apenas lhe citavam o Menina e moça [Saudades], e os 'imortais' recorriam ao seu rouxinol sempre que precisavam dum passarinho que não fosse vira-bosta. Eu tinha-o na estante e jamais o li. Pegava e largava. E como eu, todo mundo. Logo que saia, tê-lo-ás aí. Vamos fazer uma linda edição. Aquele rouxinolzinho merece gaiola dourada." 31

Com a preocupação de aproximar o texto da realidade de seu país, as crianças também ganharam versões abrasileiradas das fábulas de Esopo, La Fontaine e Fedro, adaptações de Gullivers Travels, Dom Quixote de La Mancha, Alice in Wonderland, Hans Staden, Peter Pan and Wendy...

O projeto de escrever para crianças manifesta-se em 1916, quando Lobato critica a qualidade das traduções que circulavam no país e a própria defasagem quanto à literatura infantil:

"Ando com várias ideias. Uma vestir à nacional as velhas fábulas de Esopo e La Fontaine, tudo em prosa e mexendo nas moralidades. Coisa para crianças.[...] Ora, um fabulário nosso, com bichos daqui em vez dos exóticos, se for feito com arte e talento dará coisa preciosa. As fábulas em português que conheço, em geral traduções de La Fontaine, são pequenas moitas de amora-do-mato - espinhentas e impenetráveis. Que é que nossas crianças podem ler? Não vejo nada. Fábulas assim seriam um começo da

\footnotetext{
${ }^{30}$ LOBATO, Monteiro. “Traduções”. In: Mundo da lua e miscelânea. 8 a ed. São Paulo: Brasiliense, 1957, p. 127.

${ }^{31}$ IDEM. A barca de Gleyre. Ed. cit., p. 495-6. Carta de São Paulo, 25/09/1924.
} 
literatura que nos falta. Como tenho um certo jeito para impingir gato por lebre, isto é, habilidade por talento, ando com ideia de iniciar a coisa. É de tal pobreza e tão besta a nossa literatura infantil, que nada acho para a iniciação de meus filhos. Mais tarde só poderei dar-lhes o Coração de Amicis - um livro tendente a formar italianinhos." ${ }^{32}$

Este trecho da carta de Lobato a Rangel é exemplar para discutir diferentes aspectos do escritor para crianças que está em formação. Sem perder de vista a preocupação com o Lobato leitor, é preciso notar que, estimulado por sua leitura de La Fontaine e de outros livros infantis, ele sente a necessidade de escrever para as crianças brasileiras. Sua constante preocupação com a linguagem e, principalmente, o desejo de envolver e tornar a literatura acessível a qualquer leitor, motivaram-no a encontrar uma forma peculiar de traduzir e adaptar.

Sua fidelidade ao texto tinha o sentido de traduzir o pensamento do autor, "Não entendia, nem aceitava, a versão literal, ao pé da letra., ${ }^{33}$ Logo, pode-se dizer que, para Lobato, traduzir ou adaptar significava também criar. A inserção de elementos estrangeiros às narrativas levaram aspectos da literatura de outros povos para o espaço do Sítio do Picapau Amarelo. Míriam Giberti Páttaro Pallotta aponta que:

"Em certas obras como Reinações de Narizinho, Fábulas, D. Quixote de La Mancha, O Minotauro e Os doze trabalhos de Hércules, ocorre uma 'apropriação' de outras culturas, um diálogo extremamente fértil de elementos clássicos e contemporâneos, que provoca uma atualização de elementos estrangeiros e alheios ao contexto brasileiro." 34

A intensa rotina de escritor, editor e tradutor preenche o tempo de Lobato que, em 1925, numa tentativa de parceria, oferece ao amigo Rangel textos para traduzir:

"Andas com tempo disponível? Estou precisando de um Dom Quixote para crianças, mais correntio e mais em língua da terra que as edições do Garnier e dos portugueses. Preciso do Dom Quixote, do Gulliver, do Robinson, do diabo! Posso mandar serviço? É uma distração e ganhas uns cobres. Quanta coisa tenho vontade de fazer e não posso! Meu tempo é curto demais." 35

\footnotetext{
${ }^{32}$ IDEM, ibidem, p. 370. Carta da Fazenda, 08/09/1916.

${ }^{33}$ CAVALHEIRO, Edgard. Op. cit., p. 537.

${ }^{34}$ PALLOTTA, Míriam Giberti Páttaro. Reflexões sobre a prática da tradução para Monteiro Lobato: análise da obra Fábulas. In: XI Congresso Internacional da ABRALIC. Tessituras, Interações, Convergências, 13 a 17 de julho de 2008, São Paulo. Anais do XI Congresso Internacional da ABRALIC. São Paulo: Universidade de São Paulo, 2008. Disponível http://www.abralic.org.br/anais/cong2008/AnaisOnline/simposios/pdf/065/MIRIAM_PALLOTTA.pdf Acesso em: 14 nov. 2013.

${ }^{35}$ LOBATO, Monteiro. A barca de Gleyre. Ed. cit., p. 500. Carta de São Paulo, 08/03/1925.
} 
Uma síntese dos esforços em tentar conciliar as diferentes ocupações pode ser vista na carta a Rangel em 16 de junho de 1934:

"Tenho empregado as manhãs a traduzir, e num galope. Imagine só a batelada de janeiro até hoje: Grimm, Andersen, Perrault, Contos de Conan Doyle, O homem invisivel de Wells e Pollyana moça, o Livro da jângal. E ainda fiz a Emília no país da gramática. Tudo isto sem faltar ao meu trabalho diário na Cia. Petróleos do Brasil, com amiudadas visitas ao poço do Araquá. Positivamente não sei explicar como produzi tanto sem atrapalhar o meu trem normal da vida." ${ }^{36}$

Cabe ressaltar que o dialogismo e a intertextualidade na criação são recursos muito explorados por Lobato, levando-o a apropriar-se de personagens como Hércules, Alice, Branca de Neve, Peter Pan, etc. Em obras como História do mundo para as crianças, Geografia de Dona Benta e História das invenções, as crianças do Sítio escutam a história contada por Dona Benta e interagem com a narrativa, maneira lobatiana de adaptar os textos estrangeiros.

Até aqui, esta dissertação ocupou-se de rastrear referências a leituras deixadas nas páginas d'A barca de Gleyre, relatando Lobato leitor em suas diversas fases: o escritor em formação, o editor e o tradutor. $\mathrm{Na}$ impossibilidade de trabalhar unicamente com o acervo lobatiano, dada a parcial dispersão, recorremos à correspondência para nos auxiliar na tarefa de identificar algumas das leituras e reconstituir, ainda que virtualmente, parte da biblioteca de Monteiro Lobato.

\footnotetext{
${ }^{36}$ IDEM, ibidem, p. 541. Carta de São Paulo, 16/06/1934.
} 


\section{PARTE II}

\section{VESTÍGIOS DA BIBLIOTECA DE MONTEIRO LOBATO}




\section{Capítulo 1}

\section{Das cartas até a biblioteca do escritor}

“- Quer ficar com meu arquivo"?

Monteiro Lobato ${ }^{1}$

Quem se interessaria por uma papelada imensa: recortes, cartas, documentos, livros...? E se esse material tivesse pertencido a um importante escritor do início do século XX?

Monteiro Lobato surpreende o amigo e futuro biógrafo Edgard Cavalheiro quando, de mudança marcada para a Argentina, em 1946, confia a ele seu arquivo:

"A pergunta, como é natural, deixou-me estatelado. Já havia visto parte
desse material. Lera muitas cartas, usara mesmo certo álbum de recortes ao
redigir a introdução de Urupês. Não podia desconhecer o valor daqueles
documentos nem a importância do destinatário na vida mental do Brasil.
Como responder, senão com um 'Claro!', bem aberto, bem acolhedor?"2

É a partir desse material que, em 1955, Cavalheiro organiza a biografia Monteiro Lobato: vida e obra. Diferente do que ocorre com alguns escritores como Mário de Andrade, cujo arquivo encontra-se conservado no Instituto de Estudos Brasileiros da Universidade de São Paulo, o acervo de Lobato está disperso. Mudanças de endereços, empréstimos e doações de livros e de documentos pessoais, entre outros fatores, contribuíram, para essa situação. Segundo Joyce Campos, a neta de Lobato, após a morte dele e a de Cavalheiro, provavelmente as pessoas foram se servindo do arquivo, que desapareceu aos poucos. Ao tomar consciência disso, Purezinha, esposa de Lobato, teria encarregado o genro Jurandir Ubirajara Campos de reaver o arquivo. Porém, o conjunto dos documentos já estava espalhado.

Assim como o arquivo, a biblioteca de Lobato também acabou tomando diferentes rumos ao longo dos anos. Joyce Campos recorda-se da relação do avô com os livros:

"Por causa da vida atribulada, com atividades aqui e acolá, doença dos filhos e viagens constantes, inclusive para morar no exterior, meu avô estava sempre de mudança. Era o único escritor que não tinha biblioteca montada. Por isso, nem desencaixotava os livros, tirava para fora só o essencial. Desde

\footnotetext{
${ }^{1}$ CAVALHEIRO, Edgard. Monteiro Lobato: vida e obra. São Paulo: Cia Editora Nacional, 1955, p. 13.

${ }^{2}$ IDEM, ibidem, p. 13.
} 
que me lembro, os livros ficavam em grandes caixotes no porão em todas as casas onde viveu. Alguns, espalhavam-se pelas salas e quartos, e ele costumava dar um ou outro para os amigos que apareciam. Quando sobrava um exemplar, fazia uma dedicatória para mim. [...]

"No escritório pequeno, de três por quatro metros, em que não cabia muita coisa, meu avô guardava alguns volumes para consulta e uma pilha que estava lendo no momento. Não tinha na parede uma estante cheia de livros, de alto a baixo, aquela coisa maravilhosa, não. Era só um armário com prateleiras e portas de vidro que ele levava de um lugar para o outro, feito uma biblioteca ambulante. Como ele recebia livros novos todo dia, em um mês o armário que andava para lá e para cá em todas as mudanças já estava lotado. Mesmo porque Juca guardava todos os seus volumes de Direito e os do visconde, que era uma coleção gigante, além da maioria dos autores franceses. Havia também livros lindos, com ilustrações do Doré."3

Vale notar que o apelido Juca continuava entre os familiares, como podemos verificar nas memórias da neta Juca e Joyce, aliás, aparece como a assinatura de Lobato em suas cartas à esposa Purezinha, à época sua noiva, correspondência publicada postumamente em 1969, em Cartas de Amor ${ }^{4}$.

Do mesmo modo que Lobato quando pequeno se deliciava na biblioteca do avô Visconde de Tremembé, Joyce Campos teve bons momentos de leitura ao lado de Juca, "De vez em quando, meu avô chamava nossa atenção para os desenhos de Dom Quixote, feitos em bico-de-pena, que ele adorava. 'Venham ver a maravilha!, dizia, com o livro aberto nos joelhos. Nós ficávamos babando...."

Após a morte de Purezinha, em 1958, os papéis de Lobato acabam ficando aos cuidados de Ruth Monteiro Lobato, filha mais nova do casal, que falece em 1972; Marta Lobato Campos, mãe de Joyce, guarda os documentos. Com o falecimento dos pais, Joyce Campos herda os livros de Lobato, da tia Ruth, da mãe Marta e do pai, o ilustrador Jurandir Ubirajara Campos. Doa a maioria para a Biblioteca Infantil: "Tirei alguma coisa de que gostava muito, mas confesso que fiquei desnorteada com aquele monte de caixotes entupidos de livros. Tenho a impressão de que, durante muitos anos, meu avô nem pôde olhar como estava aquilo, pois quando abri tinha tanto cupim que muita coisa foi jogada fora." ${ }^{\circ} \mathrm{A}$

\footnotetext{
${ }^{3}$ CAMARGOS, Marcia. Juca e Joyce: memórias da neta de Monteiro Lobato/ depoimento a Marcia Camargos. São Paulo: Moderna, 2007, p. 60-1.

${ }^{4}$ LOBATO, Monteiro. Cartas de amor. Prefácio, compilação e notas de Cordélia Fontainha Seta. São Paulo: Brasiliense, 1969.

${ }^{5}$ CAMARGOS, Marcia. Juca e Joyce: memórias da neta de Monteiro Lobato/ depoimento a Marcia Camargos. Ed. cit., p. 61.

${ }^{6}$ IDEM, ibidem, p. 61.
} 
Biblioteca Infantil Municipal, inaugurada em 14 de abril de $1936^{7}$, acresceu a seu título o nome Monteiro Lobato em 1955, em homenagem ao escritor que mostrou a importância dos livros para as crianças.

Segundo a estudiosa Azilde Lina Andreotti, com a morte do escritor, em 1948, a família entrega bens dele para a Biblioteca Infantil Monteiro Lobato, que já havia iniciado um pequeno acervo, conhecido na época como "Museu da Emília", . No que se refere ao Acervo doado:

"Iniciado nos anos 30 com figuras de personagens infantis doados por Lobato e doações da família do escritor em 1948, esse acervo contém toda a obra de Lobato: as primeiras edições dos livros de literatura infantil, seus ilustradores, traduções, adaptações, documentos pessoais, farta correspondência, homenagens, artigos sobre o autor e sua obra, artigos escritos por Lobato em vários periódicos desde o início do século $\mathrm{XX}$, livros e teses sobre Lobato, fotografias e alguns pertences seus em uma vitrine em exposição. São 3028 documentos abrangendo os vários aspectos da vida do autor e de sua obra." ${ }^{9}$

Esse acervo incorporou os livros que teriam pertencido a Lobato. Em visita à Biblioteca, conversamos com Oiram Antonini e Nelson Somma Jr., pesquisadores do Acervo Monteiro Lobato que nos informaram não haver documentos especificando quantos e quais títulos estiveram realmente na biblioteca do escritor. Entretanto, eles nos mostraram um caderninho com uma lista dos livros doados pela família, autógrafo de Hilda Junqueira Villela Merz, especialista em Lobato e funcionária da biblioteca no período 1982-1998. Como nessa lista estão arrolados títulos de publicação póstuma do escritor, pode-se pensar que, junto aos livros de propriedade de Lobato, tenham vindo outros, oferecidos pela família. Como a própria Joyce Campos afirma, ela herdara, na mesma época, livros das estantes de Lobato, bem como outros que tinham sido de sua tia, de sua mãe e de seu pai; as bibliotecas podem ter se fundido e foram assim incorporadas ao Acervo Monteiro Lobato. Outro fato que nos chama a atenção é que, além das constantes mudanças de endereço, os caixotes de livros contaram com outro inimigo, os cupins!

\footnotetext{
${ }^{7}$ A Biblioteca Infantil Municipal foi criada como parte do amplo projeto de incentivo à cultura, elaborado por um grupo de intelectuais liderado por Mário de Andrade, então diretor do Departamento de Cultura de São Paulo.

${ }^{8}$ ANDREOTTI, Azilde Lina. A formação de uma geração: educação para a promoção social e o progresso de país do jornal A Voz da Infância da Biblioteca Infantil Municipal de São Paulo (1936-1950). Tese de Doutorado (orientação: José Luís Sanfelice). Campinas, São Paulo: Universidade Estadual de Campinas, 2004, p. 4.

${ }^{9}$ IDEM, ibidem, p. 10.
} 
O que restou da Biblioteca de Monteiro Lobato? A partir do caderninho de Dona Hilda, elaboramos uma lista dos títulos doados, conforme consta do COMPLEMENTO G desta dissertação, desconsiderados aqueles de edição posterior a 1948.

As dedicatórias de escritores como Graça Aranha, Ronald de Carvalho, Sra. Leandro Dupré, Cesídio Ambrogi, Jorge Amado, entre tantos, auxiliam na reconstrução da biblioteca de Lobato. Há também livros com dedicatória a Purezinha e, curiosamente, o exemplar da Bahia de todos os santos, de Jorge Amado, está dedicado a Caio Prado Jr. Em nossa tabela, inserimos uma coluna transmitindo as observações que encontramos no caderno acerca dos títulos, como a presença de dedicatórias, de anotações de leitura e de outros elementos da materialidade. A informação sobre as anotações de leitura faz do registro elaborado por Hilda Junqueira Villela Merz o testemunho de uma rica marginalia.

Embora da listagem de Dona Hilda constem 896 exemplares, observamos que nem todos fizeram parte da biblioteca de Lobato. Afora os títulos posteriores ao ano do falecimento do escritor, 1948, há, ali, obras doadas posteriormente por diferentes pessoas, apenas algumas com indicação do ofertante. Cabe notar que o caderninho exibe alteração na letra, na cor da tinta da caneta utilizada e no modo de registrar, pois outros anotadores se fazem ver. As folhas iniciais são mais precisas e completas quanto à informação que, nas finais, contenta-se em apontar autores e títulos. Notamos duplicação e triplicação no registro de títulos, o que reduz o número real para 422 ou talvez menos.

Tivemos dificuldade em levantar os títulos que realmente pertenceram ao escritor. Inclusive, o próprio caderninho de Dona Hilda era considerado um documento "perdido" por conta da mudança de sala do Acervo Monteiro Lobato. Mesmo com ressalvas, esse achado foi fundamental para elaborarmos uma primeira relação daquilo que restou da biblioteca original.

Além do material conservado na Biblioteca Infantil Monteiro Lobato, há também o Fundo Monteiro Lobato, localizado no Centro de Documentação Cultural Alexandre Eulálio, do Instituto de Estudos da Linguagem, da Unicamp. O acervo é constituído por documentos que se referem à vida pessoal e profissional do titular como escritor, editor, adido comercial, desenhista e empreendedor. $\mathrm{O}$ arquivo inclui documentos pessoais, correspondência com amigos, escritores, editores etc., além daquela trocada com Maria Pureza Natividade durante o 
período de namoro. O fundo também conta com livros, manuscritos e datiloscritos de contos, crônicas e traduções, além de desenhos, aquarelas e fotografias da autoria de Lobato ${ }^{10}$.

A formação do acervo é tão repleta de aventura quanto os rumos dos documentos que pertenceram a Lobato.

Fato curioso sucedeu à pesquisadora Cilza Carla Bignotto que, durante o mestrado, encontrou em Santos um rapaz, Luís Martins, vendendo cartões, moedas, livros e outras antiguidades, debaixo da marquise de um prédio. Ao ver os livros espalhados sobre uma mesa de armar, Cilza percebeu obras raras de Monteiro Lobato, vendidas a partir de R 2,00. Descobriu que aquele conjunto tinha pertencido a um colecionador, Newton Nebel dos Santos. Entre as peripécias dessa investigação detetivesca, Cilza foi parar em um porão que continha preciosidades: primeiras edições, traduções, O Sítio do Picapau Amarelo em russo, revistas com textos do escritor, entre outras. Enfim, esse conjunto de documentos foi adquirido, com verba da FAPESP, para integrar a Coleção Biblioteca Lobatiana, na UNICAMP $^{11}$.

Foi na exposição feita para anunciar a chegada, ao CEDAE, desta coleção descoberta em Santos, que a neta do escritor, Joyce Campos, e o marido dela, Jerzy Kornbluh, demonstraram interesse em doar o restante do acervo conservado na residência do casal, no Jardim Paulistano, em São Paulo. Em 20 de julho de 2000, a doação foi feita em comodato ${ }^{12}$.

Consta do Sistema de Arquivos Históricos, disponível no site do Instituto de Estudos da Linguagem, uma relação dos documentos depositados no Fundo Monteiro Lobato ${ }^{13}$. Em se tratando da biblioteca do escritor, elaboramos uma tabela a partir das informações expostas no fundo doado pela família, na qual 74 referências a possíveis leituras de Monteiro Lobato foram rastreadas, conforme mostra o COMPLEMENTO H nesta dissertação.

Em visita a Biblioteca Infantil Monteiro Lobato, localizamos no acervo o exemplar de A Child's History of the World, de Virgil Mores Hillyer, com notas da leitura de Lobato que representam elementos da gênese da adaptação de História do mundo para as crianças.

\footnotetext{
${ }^{10} \mathrm{O}$ total é de 600 manuscritos/datiloscritos e 468 impressos, 600 fotografias, 165 desenhos e aquarelas e 7 objetos.

${ }^{11}$ FÁVARO, Tatiana. Tão bisbilhoteira quanto Emília. Jornal da Unicamp, Campinas, abril de 2002. Disponível em: http://www.unicamp.br/unicamp/unicamp_hoje/ju/abril2002/unihoje_ju173lobato_pag03.html Acesso em: 08 dez. 2013.

${ }^{12}$ Azilde Lina Andreotti justifica essa escolha pela Unicamp dado que a família de Lobato não se dispunha em doar esse material para Biblioteca Infantil por não achar esse espaço o mais adequado. Cf. ANDREOTTI, Azilde Lina. Op. cit., p. 10.

${ }^{13}$ Disponível em: http://www.unicamp.br/sahu/index.html. Acesso em 18 out. 2013.
} 
Embora n'A barca de Gleyre não existam menções a Hillyer, escolhemos finalizar esta dissertação estudando esse exemplar com o objetivo de conhecer mais da faceta Monteiro Lobato leitor.

\section{Um pouco de história antes da História!}

Virgil Mores Hillyer (1875-1931), graduado na área de educação em Havard, foi professor na escola primária Calvert School, na cidade de Baltimore, e tornou-se diretor dela em 1899.

O livro A Child's History of the World foi publicado em 1924, a partir de uma experiência da Calvert School, voltada para a educação de crianças que não frequentavam escola. Do sistema de ensino domiciliar, o Home Instruction Department, criado por Hillyer em 1905, deriva a produção de material e de estratégias para compensar a ausência do professor e da sala de aula.

Escritor perspicaz e atento a seu público, Hillyer vale-se de recursos estruturais e estilísticos em sua escrita voltada para as crianças, entre os quais, a escolha e o uso criterioso de palavras capazes de despertar a atenção e a criatividade; a transmissão de informações claras e precisas, ligadas à realidade do leitor; o aproveitamento do aspecto visual de capítulos com títulos extremamente provocativos e o uso de imagens ${ }^{14}$.

Assim como o escritor norte-americano utiliza determinadas estratégias para atrair seus leitores, Monteiro Lobato, como se sabe, também se prende à elaboração de um estilo calcado na clareza da linguagem. Se alguma palavra ou expressão apresenta qualquer tipo de dificuldade para o leitor, ele encaixa didaticamente uma explicação, como nesta passagem em que temos o significado das palavras "Mesopotâmia" e "Mediterrâneo", em sua tradução/ adaptação, História do mundo para as crianças:

\footnotetext{
${ }^{14}$ PALlOTTA, Míriam Giberti Páttaro. Uma história meio ao contrário: um estudo sobre História do mundo para as crianças de Monteiro Lobato. Tese de Doutorado (orientação Carlos Erivany Fantinati). Assis, SP: Universidade Estadual Paulista Júlio de Mesquita Filho, UNESP, 2001.
} 
“[...] As terras compreendidas entre os dois rios [Tigre e Eufrates] são famosas, porque nelas muitas civilizações se formaram, que depois foram destruídas. Mesopotâmia, chama-se essa região. Vamos ver quem decompõe esta palavra.

"Pedrinho olhou para a menina, a menina olhou para a boneca, a boneca olhou para o visconde. Mas nenhuma boca abriu.

"- Meso, em grego, explicou dona Benta, quer dizer entre, e potamos quer dizer rio. Terra entre rios é o que significa a palavra Mesopotâmia. Se agora olhamos para oeste, vemos um mar chamado Mediterrâneo, que banha um país chamado Egito. Que quer dizer Mediterrâneo, Pedrinho?

"- Isso eu sei. Quer dizer mar entre terras, ou no meio de terras.","

O papel ativo da criança no processo da aprendizagem é uma preocupação que aproxima Hillyer e Lobato, tendo este se envolvido com o movimento escolanovista e com os pioneiros da Escola Nova e cultivado correspondência com Anísio Teixeira (1900-1971). Segundo Míriam Giberti Páttaro Pallotta, os teóricos que influenciaram o trabalho de Hillyer foram Rousseau, Pestalozzi, Herbart, Froebel e William James ${ }^{16}$.

Outro ponto em comum é que ambos consideram a opinião de seus leitores no processo de criação de suas obras.

Raquel Afonso da Silva, na tese de doutoramento Entre livros e leituras: Um estudo de cartas de leitores, traz o diálogo entre Monteiro Lobato e a menina Maria de Lourdes (apelidada de Rã) que, em carta de 1940, procura participar da criação de A reforma da Natureza, livro que sai em 1941. Fato é que Lobato transforma a leitora no personagem Rã da narrativa em que incorpora as propostas recebidas. Na carta a Lobato, a sugestão é esta:

“(...) podemos modificar também o descarado do Rabicó. No focinho êle levará um certo aparelho de minha invenção, um pouco parecido com uma ratoeira que lhe dará um 'liscabão' daqueles, toda vez que êle fôr fossar minhocas ou roubar cocadas. As pernas serão trocadas por umas de tartaruga bem lesma, para impedi-lo de 'desaparecer veloz pela fímbria do horizonte' quando merecer um bom ponta-pé pedriniano. $\mathrm{O}$ rabinho, para ficar mais chique, pode ser feito o de um cachorrinho lulu, dos bem frisadinhos. $\mathrm{O}$ nariz (já reparou que porco vive de nariz escorrendo?) terá um lenço automático que de 5 em 5 minutos dê uma limpadela em regra.

"Que tal? Já é alguma coisa... Ai! Tive uma idéia! Linda! Idéia mãe! Que tal se a Emília pintasse no casco do Quindim a Branca de Neve com todos os anõezinhos em volta e todos os bichinhos também, ao lado do príncipe que a abraçava com um braço e com o outro esmagava a bruxa?

\footnotetext{
${ }^{15}$ LOBATO, Monteiro. História do mundo para as crianças. $1^{\text {a }}$ ed. Biblioteca pedagógica brasileira - Literatura infantil, série I, vol. X. São Paulo: Cia. Editora Nacional, 1933, p. 20-1.

${ }^{16}$ A partir do trabalho de Míriam Giberti, reunimos grande parte das informações que aqui retomamos sobre o trabalho de Hillyer e a obra A Child's History of the World. Cf. PALLOTTA, Míriam Giberti Páttaro. Uma história meio ao contrário: um estudo sobre História do mundo para as crianças de Monteiro Lobato. Ed. cit., p. $22-40$.
} 
“Aí o rinoceronte ficava tão lindo, tão lindo, tão tão tão lindo... que aposto que logo surgia uma rinoceronta toda pimpona com olhos de mel... Epa! E se o Quindim tivesse em vez de chifre um flecha do Cupido com um coração assado na ponta? Ah! A pobre da vaca mocha no mesmo instante propunha casamento."

Realidade e ficção misturam-se n'A reforma da natureza, onde se testemunha a apropriação das modificações sugeridas na invenção da menina:

“A reforma do Quindim, por exemplo, que a Rã fez sozinha, era a coisa mais esquisita que se possa imaginar. Em vez do famoso chifre sobre o nariz, que é característico de todos os rinocerontes, a Rã botou uma flecha de cupido com um coração assado na ponta. Assado, imaginem! E ornamentou os cascos de Quindim com pinturas; Branca de Neve com todos os seus anões." 18

“- E o Rabicó, então? - continuou Pedrinho. - Está com cauda de cachorro lulu, toda frisadinha, e só com dois pés - e pés de tartaruga. E com uma ratoeira no focinho e um lenço automático no nariz!..."

V. M. Hillyer também dispunha de leitores que lhe davam opinião sobre seus livros. Míriam Giberti Páttaro Pallotta nos conta que era costume dele consultar os alunos da Calvert School sobre seus escritos. Aliás, o manuscrito de A Child's History of the World foi lido para os alunos pelo próprio Hillyer ${ }^{20}$.

Em 1924 é publicada a primeira edição de A Child's History of the World, pela editora The Century Co., com sede em Nova Iorque e Londres. Já a versão de Monteiro Lobato vem à luz em 1933 pela Cia. Editora Nacional, parte da Coleção Biblioteca Pedagógica Brasileira Literatura Infantil, Série I, dirigida por Fernando de Azevedo. Recriada para o público brasileiro, essa foi, entre todas as obras de Lobato, a que teve maior tiragem editorial no período 1927-1955, alcançando um total de 92.156 exemplares $^{21}$.

Curiosamente, Godofredo Rangel também fez sua versão da obra de Hillyer e a intitulou Pequena história do mundo para crianças, porém, não conseguimos encontrar a data da edição.

\footnotetext{
${ }^{17}$ Carta no Arquivo Raul de Andrada e Silva, Dossiê Monteiro Lobato (C1P2C30. s/d), no Instituto de Estudos Brasileiros (USP); disponível em: SILVA, Raquel Afonso da. Entre livros e leituras: Um estudo de cartas de leitores. Tese de Doutorado (orientação: Marisa Philbert Lajolo). Campinas, São Paulo: Instituto de Estudos da Linguagem, Universidade Estadual de Campinas, 2009.

${ }^{18}$ LOBATO, Monteiro. A reforma da natureza. $2^{\mathrm{a} e d . ~ S a ̃ o ~ P a u l o, ~ G l o b o, ~ 2010, ~ p, ~} 35$.

${ }^{19}$ IDEM, ibidem, p, 41.

${ }^{20}$ PALLOTTA, Míriam Giberti Páttaro. Uma história meio ao contrário: um estudo sobre História do mundo para as crianças de Monteiro Lobato. Ed. cit., p. 39.

${ }^{21}$ PALLOTTA, Miriam Giberti Páttaro. "História do mundo para as crianças: uma obra inovadora". In: LAJOLO, Marisa; CECCANTINI, João Luís. (Org.). Monteiro Lobato, livro a livro. 1 ed. São Paulo: UNESP e Imprensa Oficial, 2008, p. 222.
} 


\title{
$\underline{\mathrm{O} \text { manuscrito de História do mundo para as crianças }}^{22}$
}

Não só as cartas de Lobato permitem um mergulho nos bastidores de sua criação. O exame no exemplar de A Child's History of the World, com notas da leitura de Lobato, recupera elementos da gênese da adaptação, quando as anotações correspondem a um primeiro manuscrito conhecido da História do mundo para as crianças. Porém, antes de iniciar a análise desse documento, faz-se necessário estabelecer o que entendemos por manuscrito. Para tanto, recorremos a Roberto Zular e Claudia Amigo Pino:

\begin{abstract}
"Por manuscrito entende-se qualquer documento no qual seja possível encontrar um traço do processo de criação, e não necessariamente os manuscritos autógrafos (do próprio punho do escritor). Assim, a crítica genética considera manuscritos, por exemplo, a correspondência do autor (se nela há discussões sobre a criação de suas obras), os datiloscritos (versões datilografadas diferentes do texto publicado) ou mesmo as gravações de voz com ideias sobre uma obra. Para evitar confusões, a geneticista brasileira Cecília Almeida Salles propôs o nome 'documentos do processo' para se referir aos manuscritos objeto da crítica genética." ${ }^{23}$
\end{abstract}

O exemplar de Lobato da obra de Hillyer é da $1^{\text {a }}$ edição e $15^{\text {a }}$ impressão, em 1924. Reproduzimos aqui as imagens das páginas que contêm algum tipo de anotação ou recorte de fragmento.

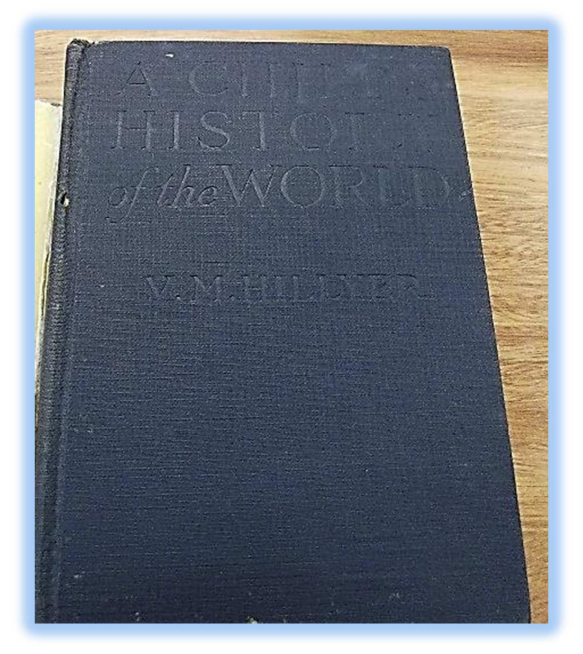

Capa do exemplar de A Child's History of the World de Lobato, conservado no acervo da Biblioteca Infantil Monteiro Lobato, São Paulo.

\footnotetext{
${ }^{22}$ A primeira versão desta parte foi desenvolvida em pareceria com Raquel Nunes Endalécio e apresentada parcialmente como comunicação sob o título "Livros, leituras e outros livros: um certo Monteiro Lobato leitor" no $2^{\circ}$ CIELLI - Colóquio Internacional de Estudos Linguísticos e Literários, realizado na Universidade Estadual de Maringá - PR, 14 jun. 2012.

${ }^{23}$ PINO, Claudia Amigo; ZULAR, Roberto. Escrever sobre escrever: uma introdução crítica à crítica genética. São Paulo: WMF Martins Fontes, 2007, p. 18.
} 


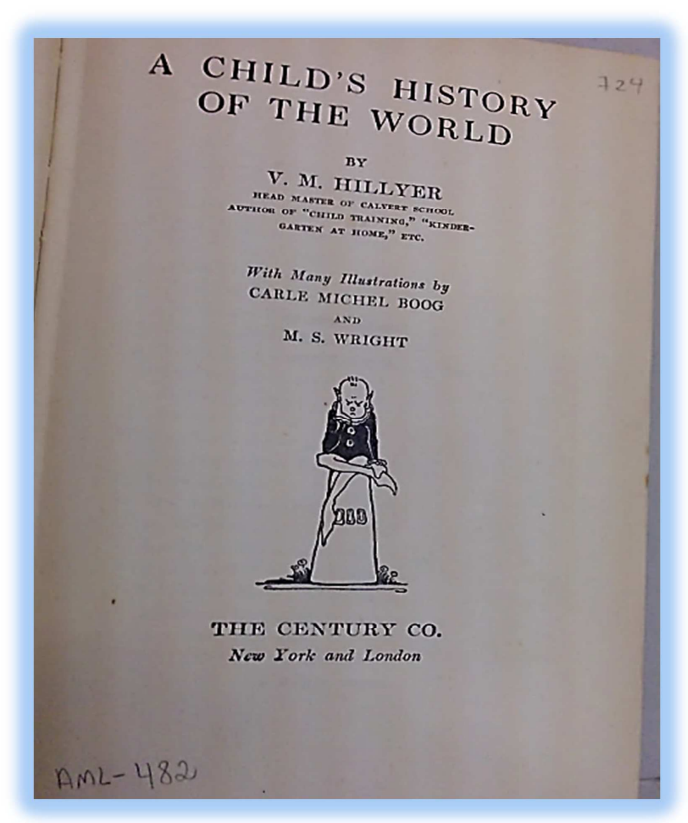

Folha de rosto do exemplar conservado no acervo do escritor (Biblioteca Infantil Monteiro Lobato, São Paulo)

Há anotações a grafite em cinquenta e quatro páginas e, em sua maioria, estão relacionadas às ilustrações no exemplar, sendo que apenas oito destacam o texto:

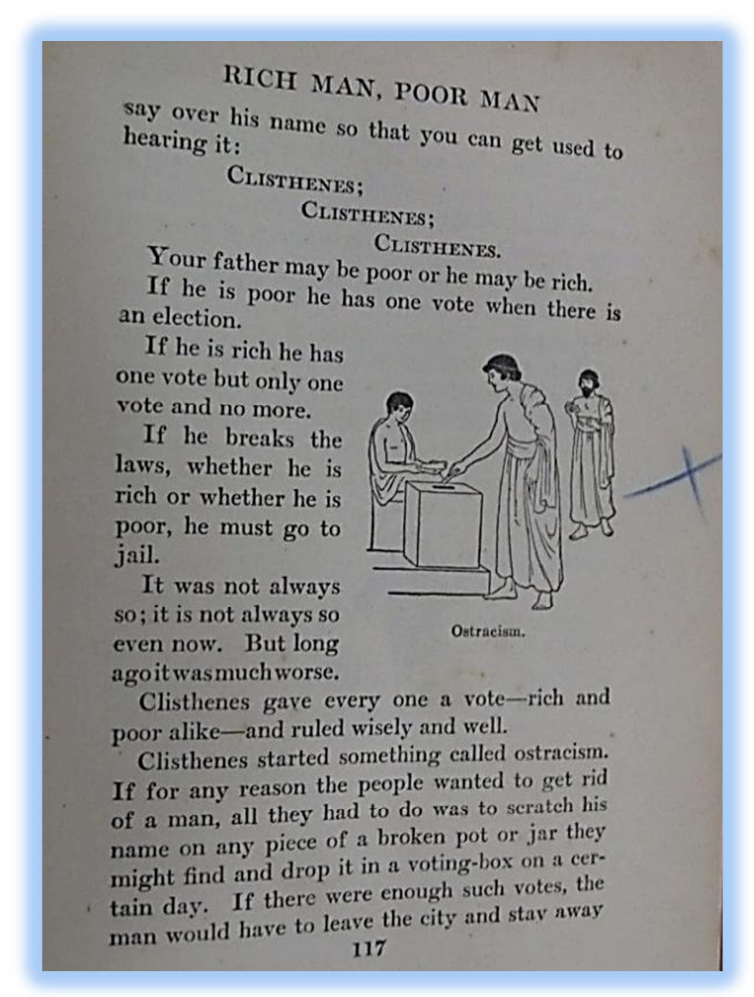

Ilustração do ostracismo assinalada com cruzeta a lápis azul na leitura de Lobato

(Biblioteca Infantil Monteiro Lobato, São Paulo) 
OFF WITH OLD ON WITH NEW

learned, and so what was the to read if they had

You can see how diffice use of learning.

for people throughout the Middle have been

books or newspapers or aiddle Ages, without

what was going on in anything printed, to learn

anything that one wanted to lno or to learn about

But, now that printing had been invented, all

that was changed. Story-books and school-books

and other books could be made in large muobs

and very cheaply. People who never before were

able to have any books could now own them.

Every one could now read all the famous stories

of the world and learn about geography, about

history, about anything he wanted to know. So

the invention of printing was soon to change

everything.

The Hundred Years' War had at last come to

an end soon after the invention of printing.

At the same time something else that was a

At the same time some to an end.

thousand years old came to an end.

The Mohammedans whom we have n't heard

of for a long time, had tried to capture Constanti-

nople in the seventh century, but had been

stopped, as I told you, by tar and pitch

Christians poured down on them.

Bristians poured down on them.

But in 1453 the Mohammedans onever, the

tacked Constantinople. This time, did n't try

Mohammedans were Turks, and the city with arrows.

to batter down the walls of the

Trecho destacado a grafite na margem direita na leitura, de Lobato; referente à carência de leitura na Idade

Média

(Biblioteca Infantil Monteiro Lobato, São Paulo)

Uma análise das notas marginais no exemplar permitiu que se traçasse relações entre elas e o texto, tomamos a primeira edição da História do mundo de Lobato para restabelecer esse diálogo do tradutor/ recriador com o livro de Hillyer, tendo em vista que o criador de Emília tinha por costume alterar momentos de sua obra a cada nova edição; em seu work in progress, acrescentava imagens, palavras e até mesmo trechos ${ }^{24}$.

Na versão de Lobato, Jurandir Ubirajara Campos é quem assina a ilustração. Entretanto, quando comparadas, a História do mundo para as crianças repete muitas imagens da obra americana, ilustrada por Carle Michel Boog e M. S. Wright, crédito esse não acusado na edição lobatiana.

\footnotetext{
${ }^{24}$ Míriam Giberti Páttaro Pallotta, em sua tese de doutorado Uma história meio ao contrário: um estudo sobre História do mundo para as crianças de Monteiro Lobato, trabalha com as diferentes edições da obra de Lobato e as analisa comparativamente. Cf. PALLOTTA, Míriam Giberti Páttaro. Uma história meio ao contrário: um estudo sobre História do mundo para as crianças de Monteiro Lobato. Ed. cit., p. 286-337.
} 
No exemplar de Lobato, as intervenções a grafite revelam a apropriação.

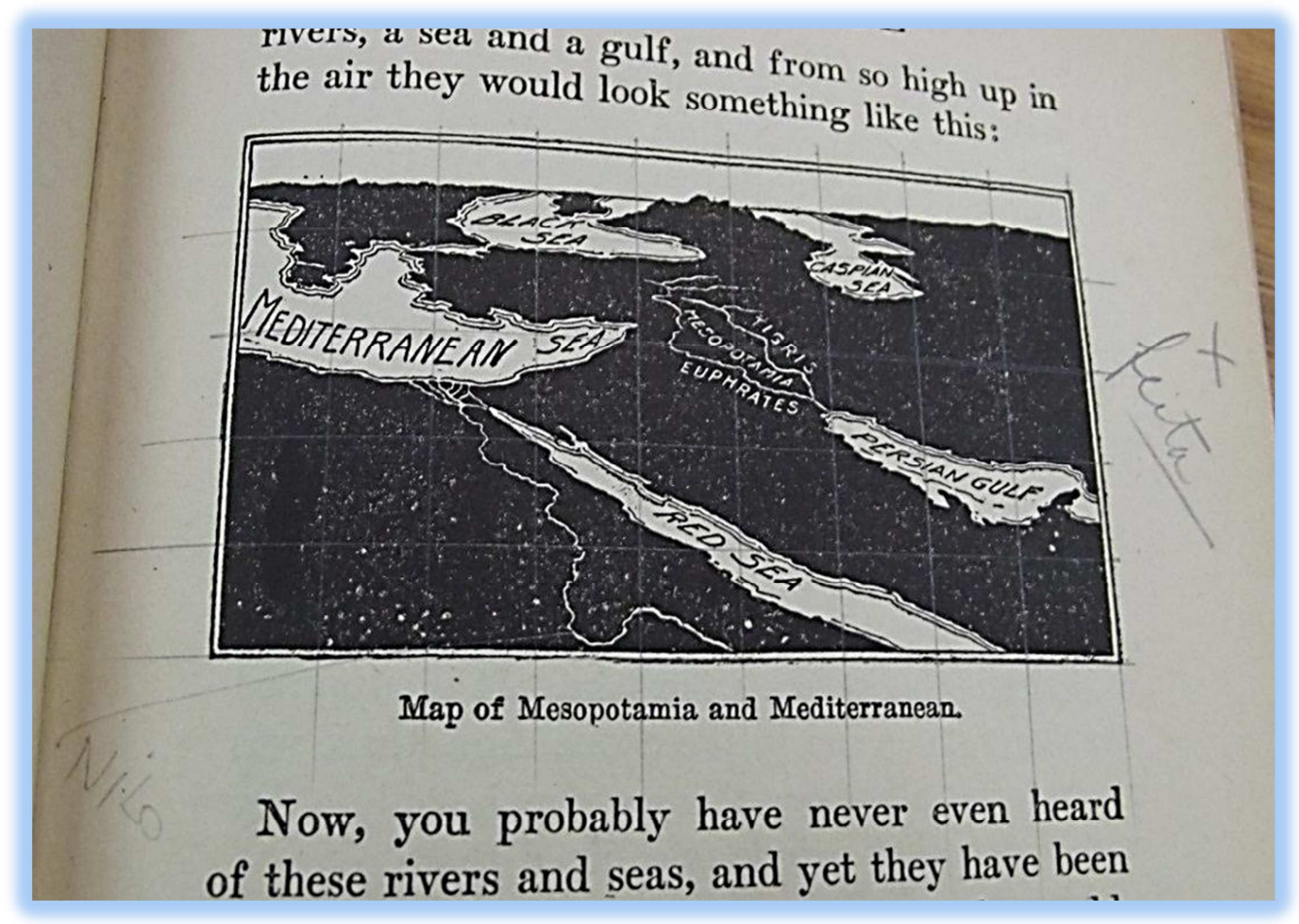

Notas de Lobato a grafite: quadriculado sobre a ilustração e indicação da apropriação a ser efetuada: "feita" e "Nilo"

(Biblioteca Infantil Monteiro Lobato, São Paulo)

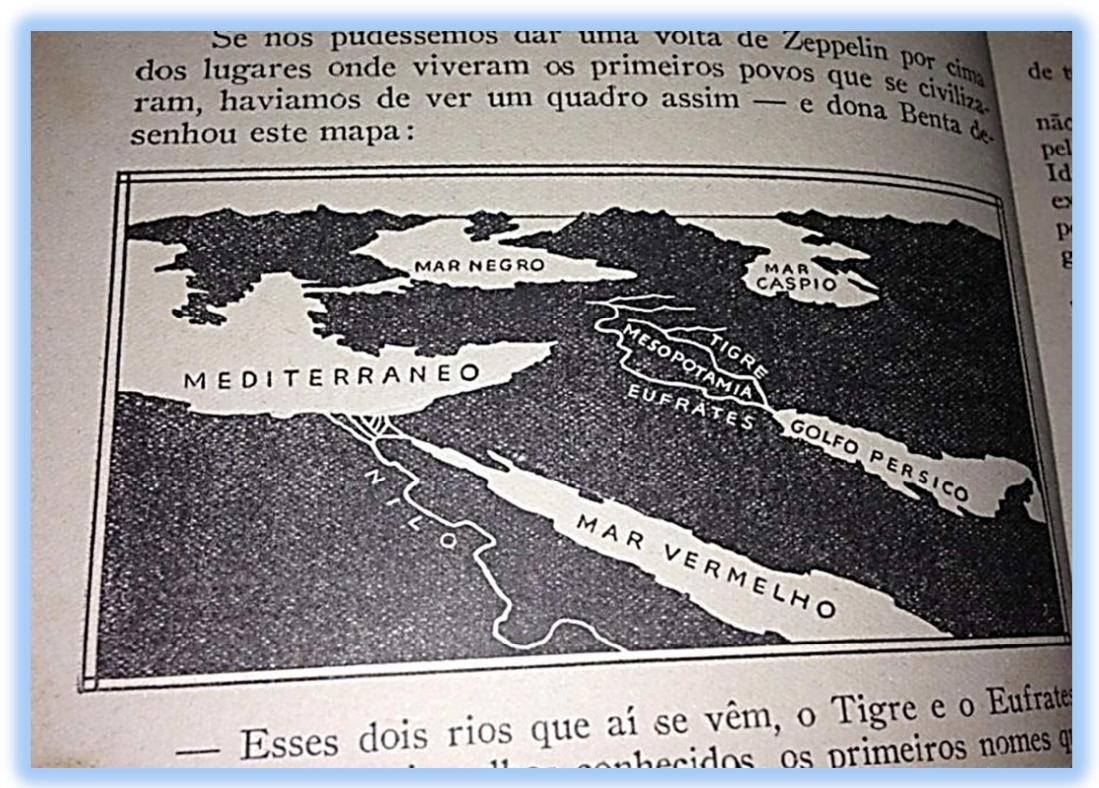

Ilustração reproduzida em História do mundo para as crianças 


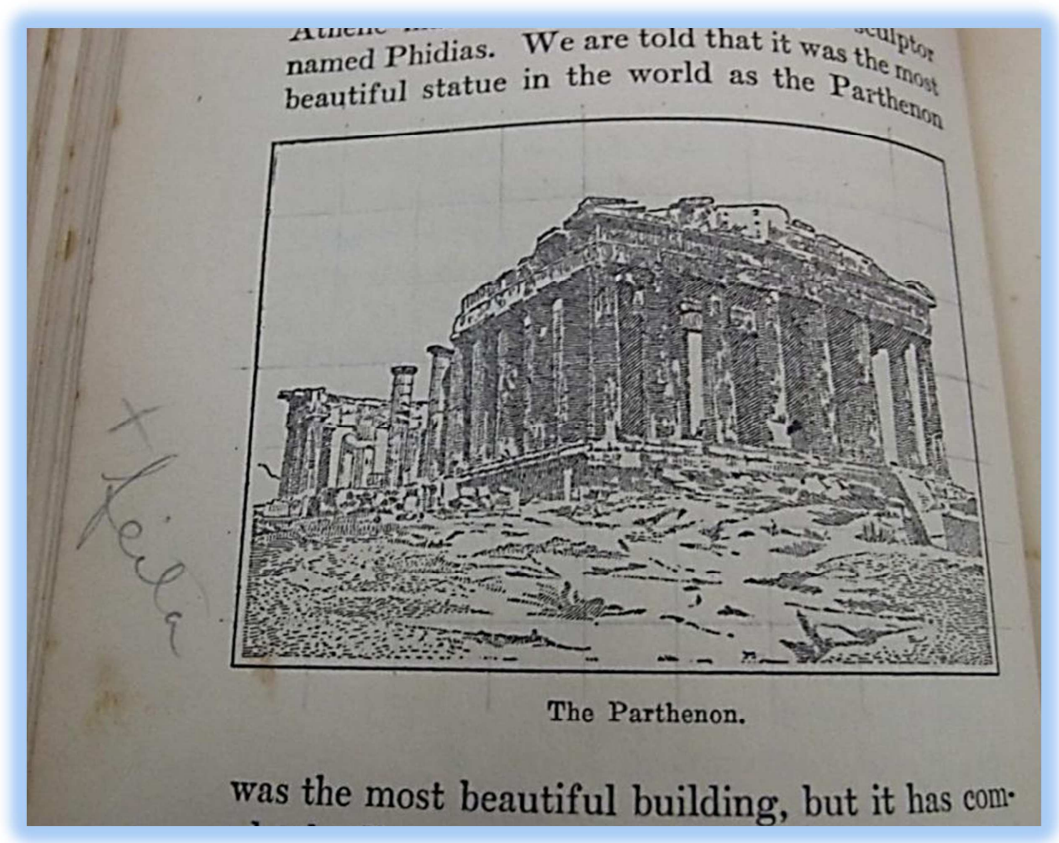

Nota de Lobato a grafite: linhas quadriculando a imagem e indicação "feita" (Biblioteca Infantil Monteiro Lobato, São Paulo)

o temas agora. Os espetaculos realizavam-senvolvido como

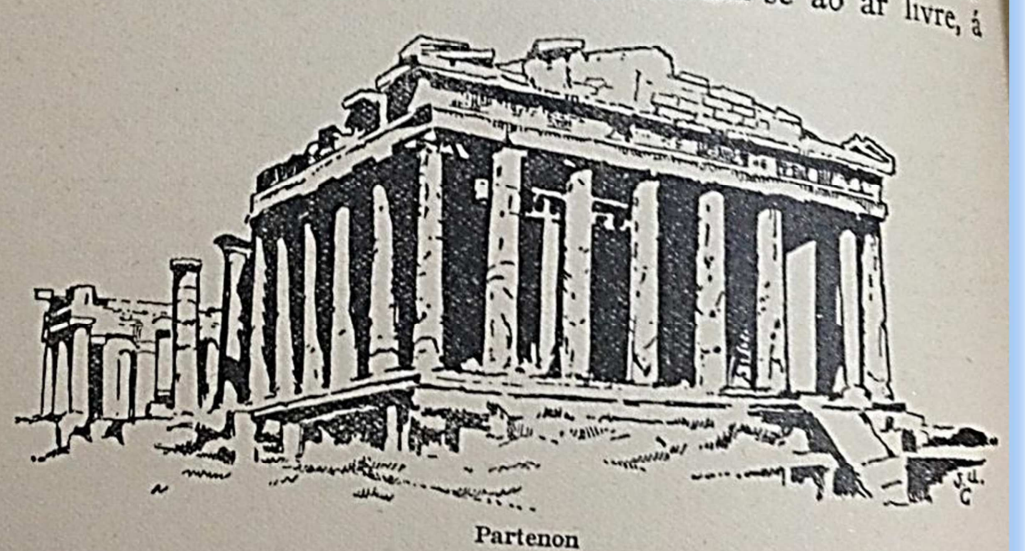

beira de encostas de morro, cuja inclinação servia de arqui um côro de cantores.

Ilustração reproduzida em História do mundo para as crianças 
Nem sempre as imagens encontram posições equivalentes. É o caso do mapa do Mediterrâneo que, em A Child's History of the World, faz parte do cap. 30 "Picking a fight", enquanto Lobato opta por inseri-lo no cap. 28 "A esperteza da Macedônia":

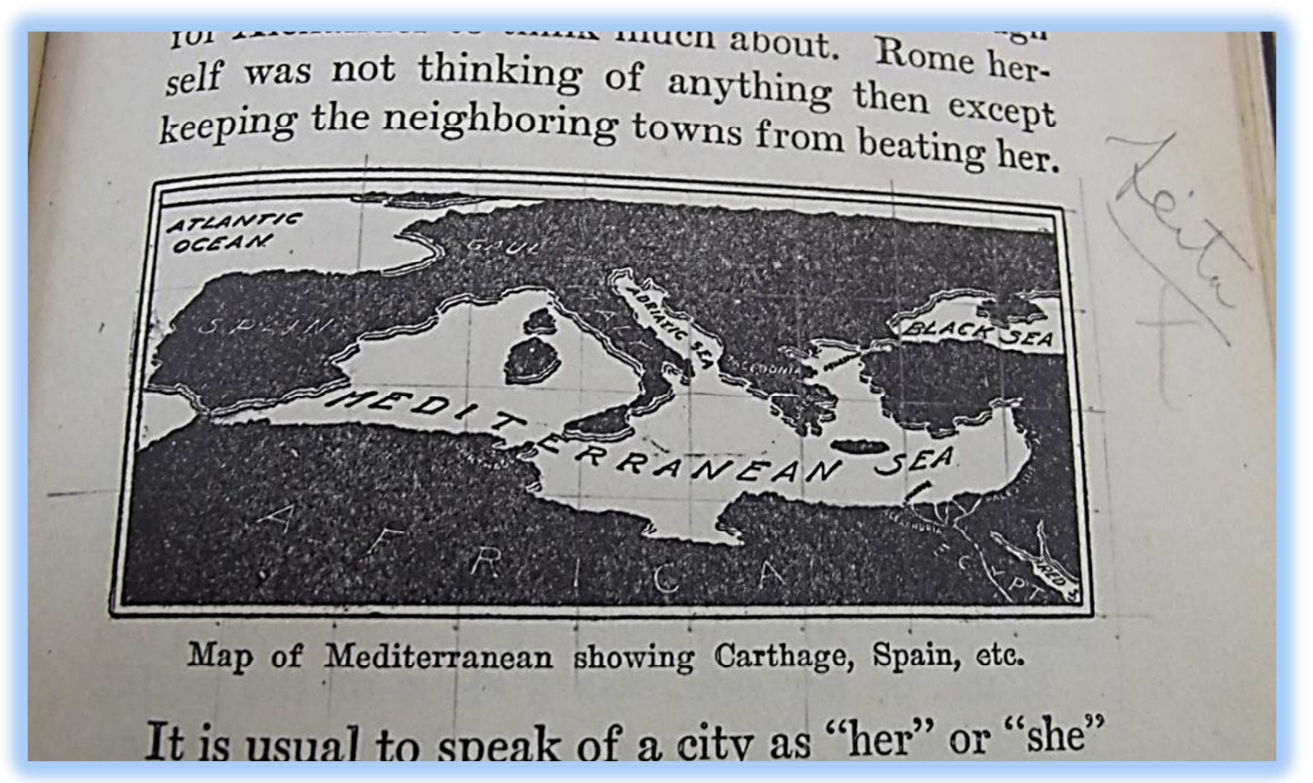

Nota de Lobato a grafite. Linhas quadriculando a imagem para reelaboração e indicação "feita" (Biblioteca Infantil Monteiro Lobato, São Paulo)

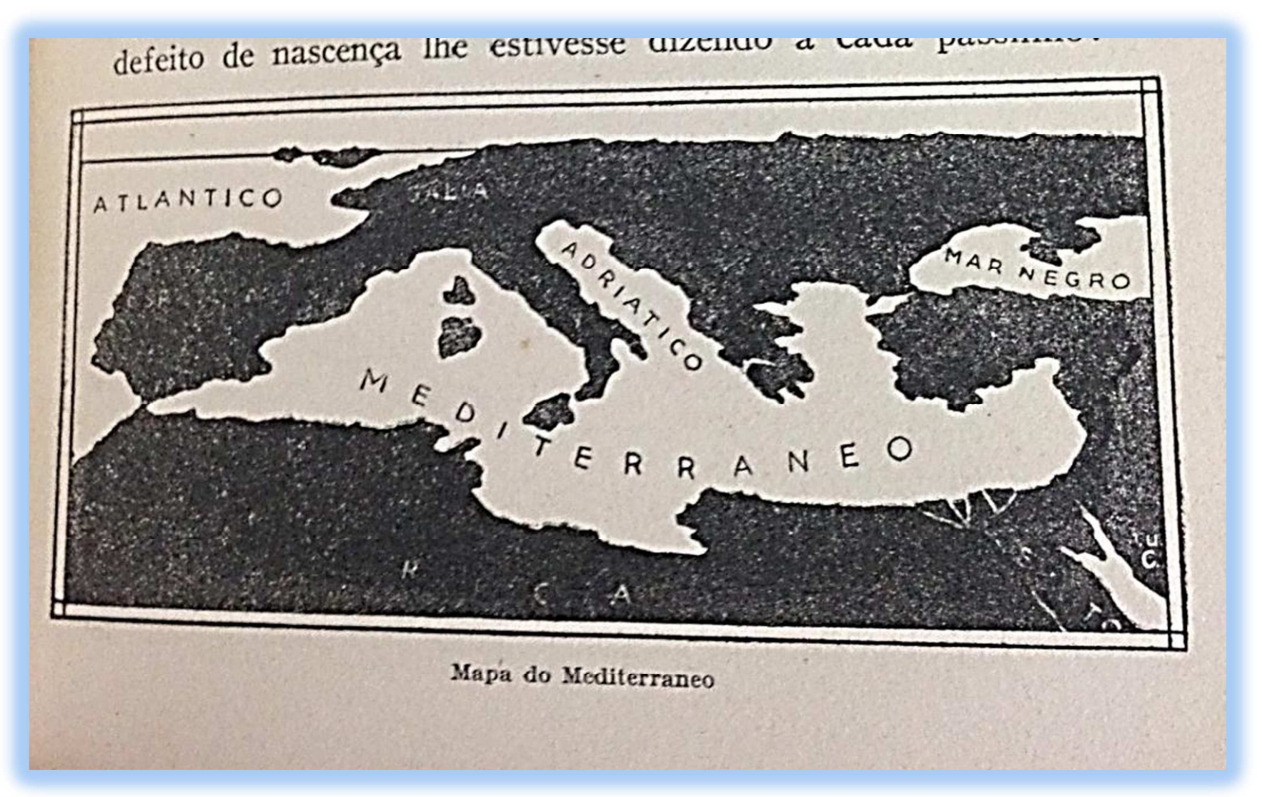

Ilustração reproduzida em História do mundo para as crianças 
Embora quadriculada e com a indicação "feita", a ilustração que oferece a nau Vitória, não faz parte da História do mundo que preferiu retratar Fernão de Magalhães que a capitaneava, desenho da autoria de J.U. Campos.

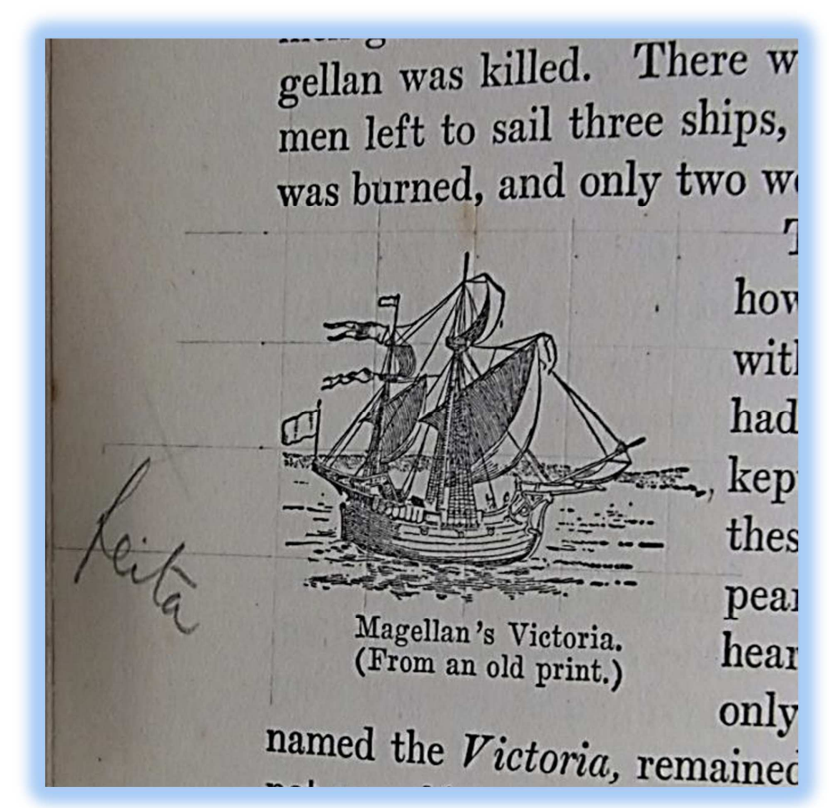

Nota de Lobato a grafite. Linhas quadriculando a imagem e indicação "feita"

(Biblioteca Infantil Monteiro Lobato, São Paulo)

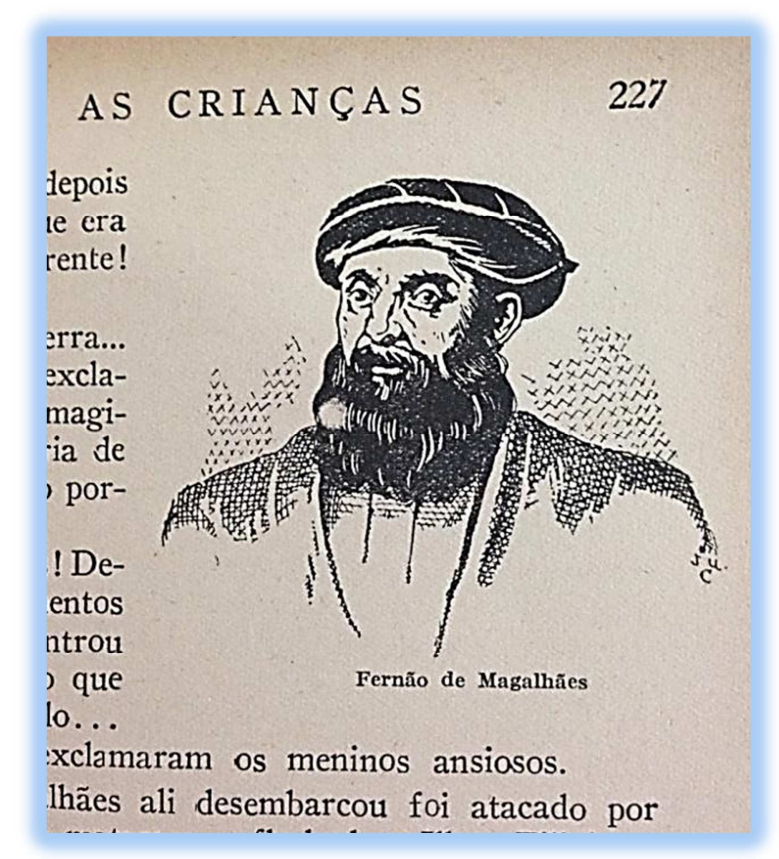

Retrato de Fernão de Magalhães na História do mundo para as crianças 
A ilustração inglesa que exibe, juntos, King Charles e Oliver Cromwell acompanhada de cruzeta a grafite riscada por Lobato, mostra também a apropriação por parte deste, nas indicações "feita" e "2 desenhos". Na História do mundo, os personagens são separados.

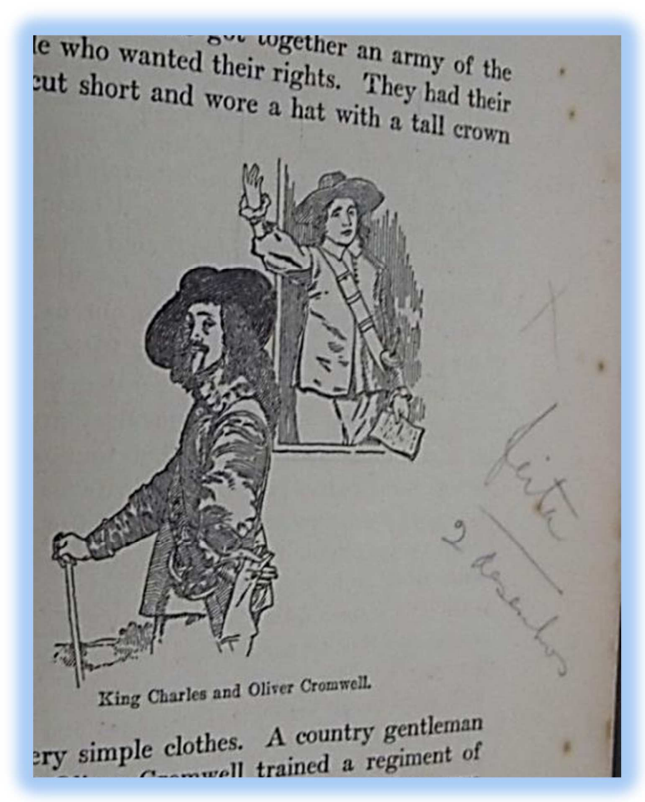

Ilustração com notas de Lobato a grafite revelando a apropriação. Indicações "feita" e "2 desenhos"

(Biblioteca Infantil Monteiro Lobato, São Paulo)

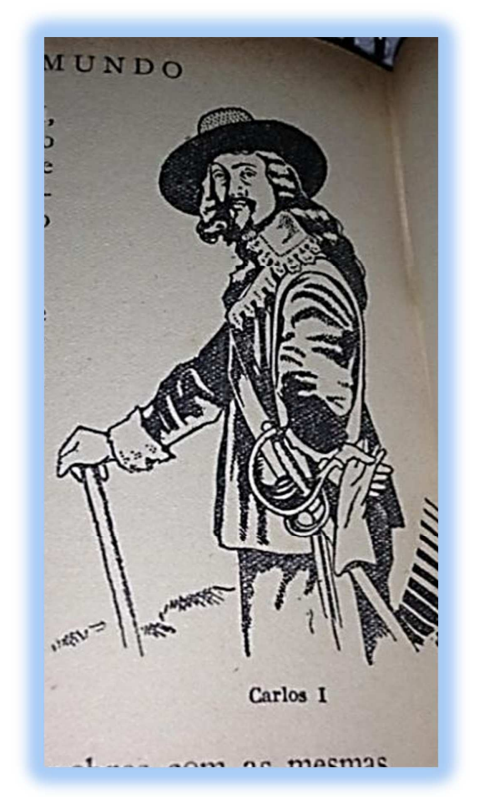

Apropriação do retrato e da legenda em História do mundo para as crianças

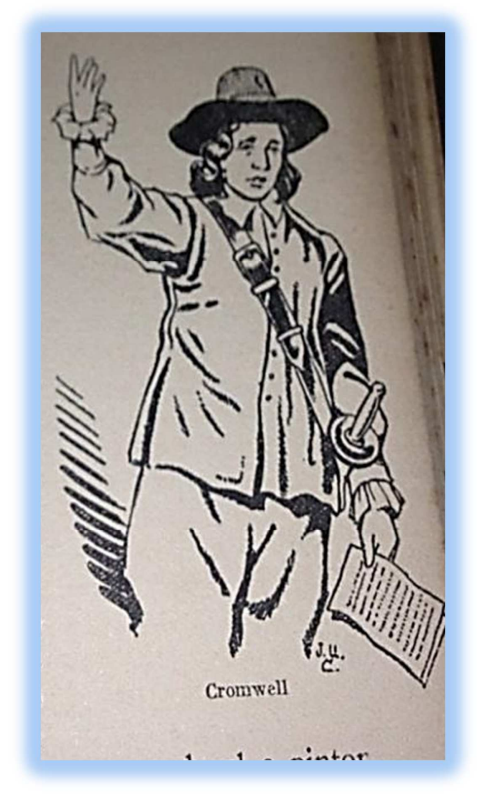

Apropriação do retrato e da legenda em História do mundo para as crianças 
A ilustração que, em Hillyer, exemplifica três tipos de colunas gregas, dórica, jônica e coríntia, revela dois momentos nas anotações relativas à apropriação por Lobato: a lápis azul e a grafite, bem como o projeto de dividir a imagem original, materializado na edição brasileira:

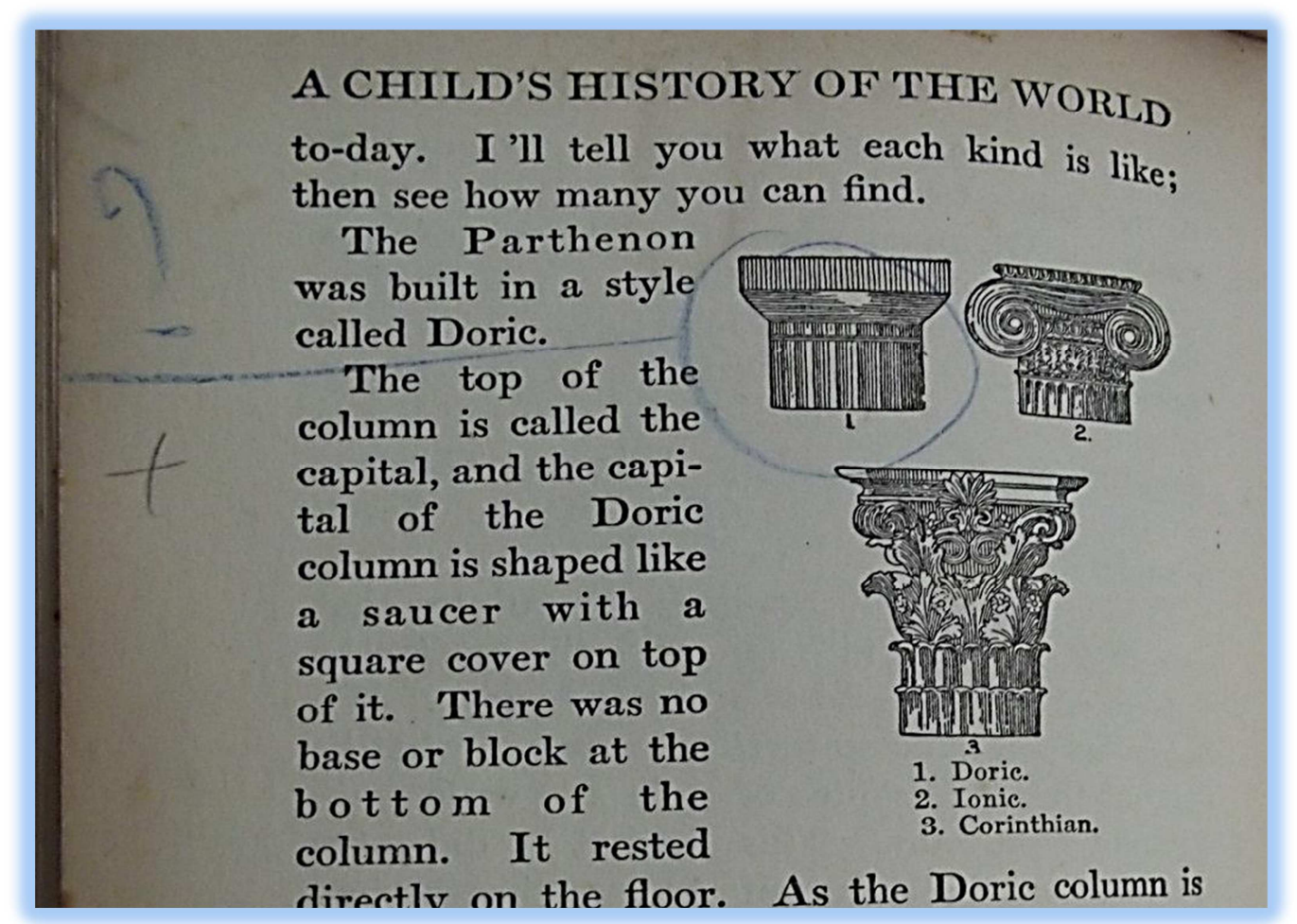

Trecho destacado por anotação a grafite e a lápis azul na leitura/ criação de Lobato (Biblioteca Infantil Monteiro Lobato, São Paulo)

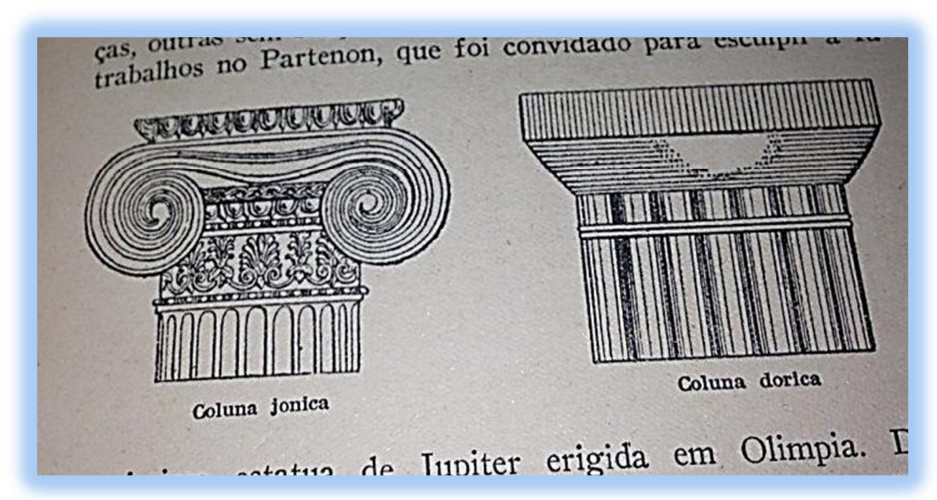

Apropriação da imagem em História do mundo para as crianças

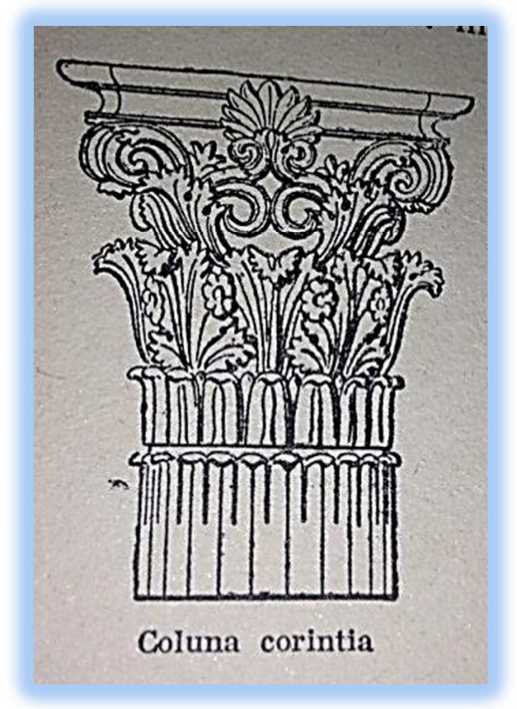

Apropriação da imagem em História do mundo para as crianças 
Estão também materializadas as apropriações no exemplar de Lobato do livro de Hillyer, vinculadas à extração de fragmentos com estilete. Assim, o nome do monarca babilônico Nabucodonosor, na escrita cuneiforme, é cortado para reaparecer em História do mundo para as crianças:

\section{"Nezzar." This is the way Nebucnaunewass} wrote his name, for he used cuneiform writing. How would you like to write your name in such a queer way? the Jews remained prisoners fot Name of Nebuchadnezzar in cuneiform writing.

$$
99
$$

Lobato corta de A Child's History of the World o nome de Nabucodonosor em escrita cuneiforme (Biblioteca Infantil Monteiro Lobato, São Paulo)

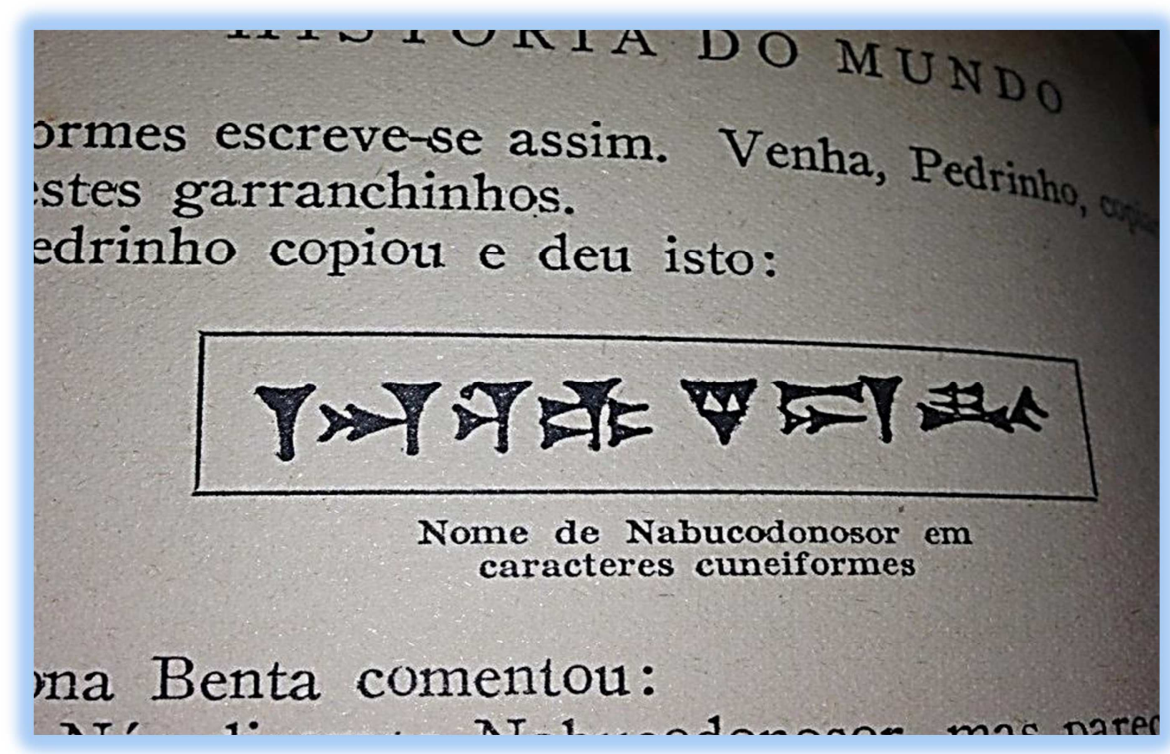

Reprodução da imagem em História do mundo para as crianças 
Caso semelhante de transferência ocorre na extração do fragmento que traz o nome de Cleópatra em hieróglifos:

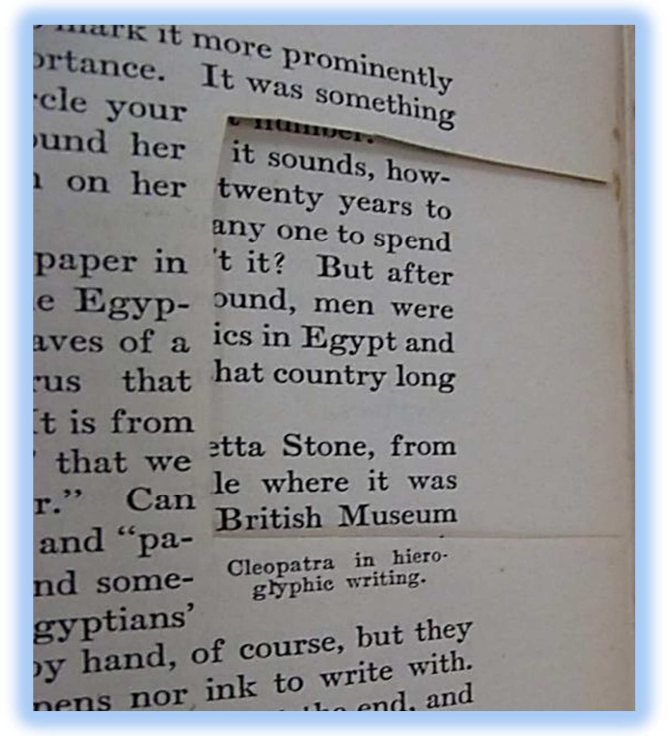

Lobato corta de A Child's History of the World o nome de Cleópatra em hieróglifo

(Biblioteca Infantil Monteiro Lobato, São Paulo)

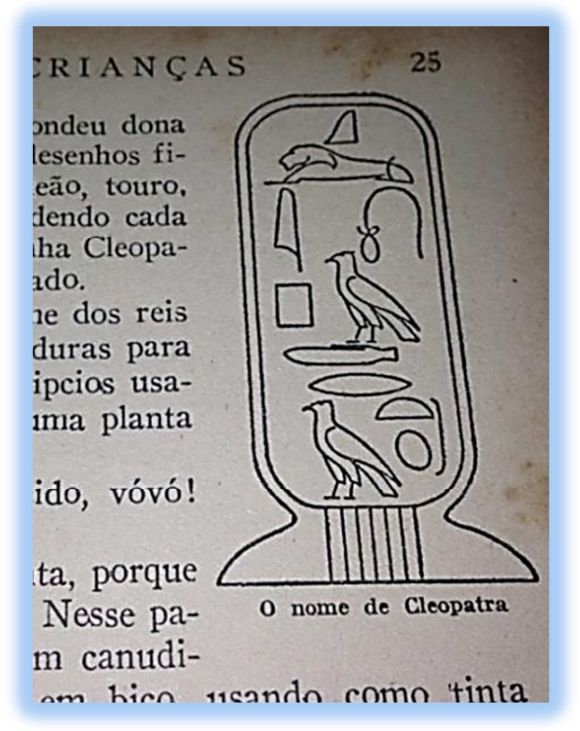

Reprodução da imagem em História do mundo para as crianças

O mesmo acontece com a imagem de Gutenberg ao lado de um prelo e a de

Shakespeare lendo para a rainha Elizabeth:

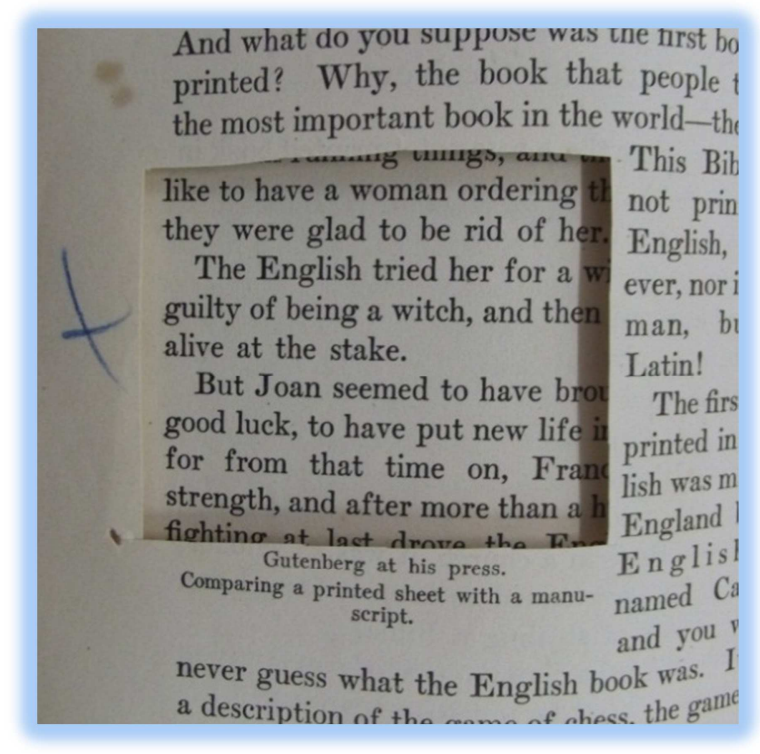

Lobato corta de A Child's History of the World a imagem de Gutenberg ao lado de um prelo (Biblioteca Infantil Monteiro Lobato, São Paulo) duzir livros na maior quantidade e a preç

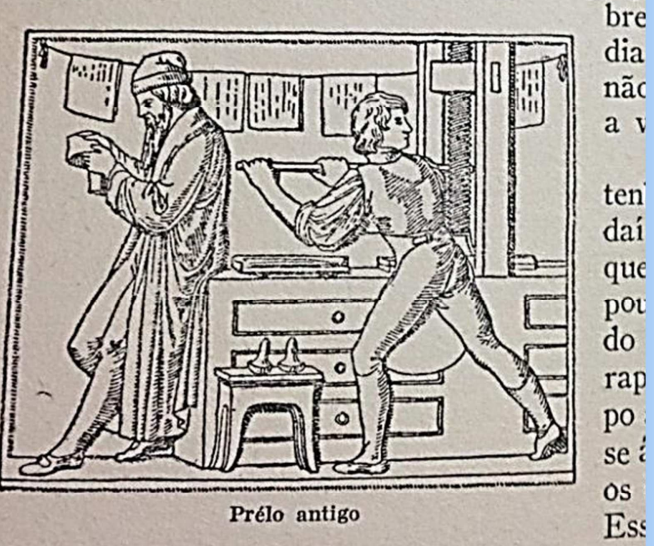

anda o mundo, e a que chamam crise, vem a marcha do progresso é mais veloz do qu

Reprodução da imagem em História do mundo para as crianças 


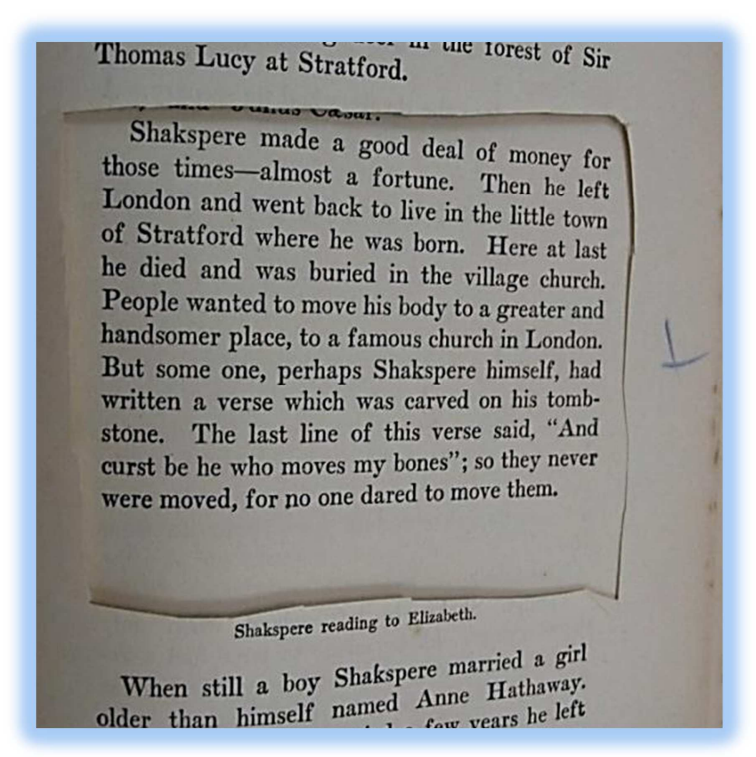

Lobato corta de A Child's History of the World a imagem de Shakespeare lendo para a rainha Elizabeth (Biblioteca Infantil Monteiro Lobato, São Paulo)

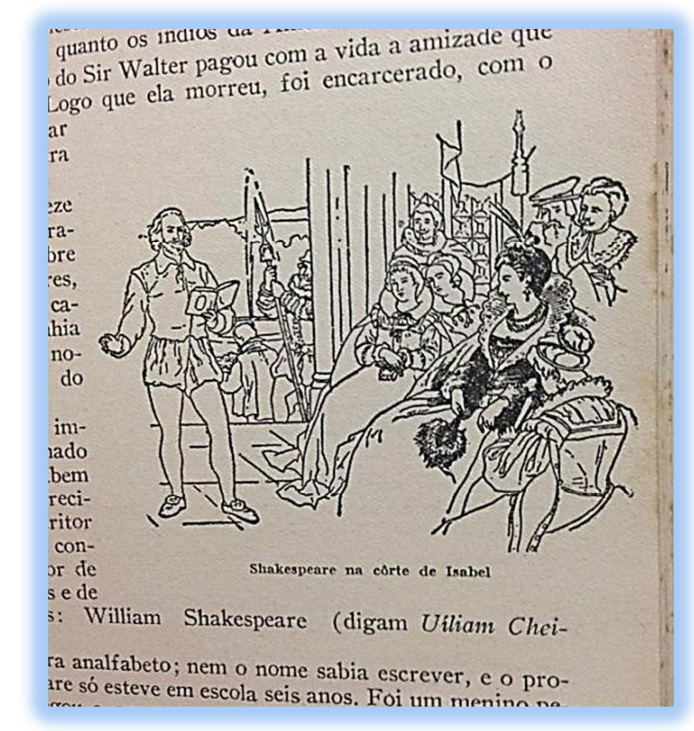

Reprodução da imagem em História do mundo para as crianças

As anotações marginais do escritor apontam projetos e decisões sobre as imagens que apareceriam em sua obra e indicam possíveis desistências. Ao lado da charge original sobre o nascimento da deusa Minerva, percebe-se que a cruzeta marginal a tinta azul foi anulada; a imagem não se repete na versão lobatiana.

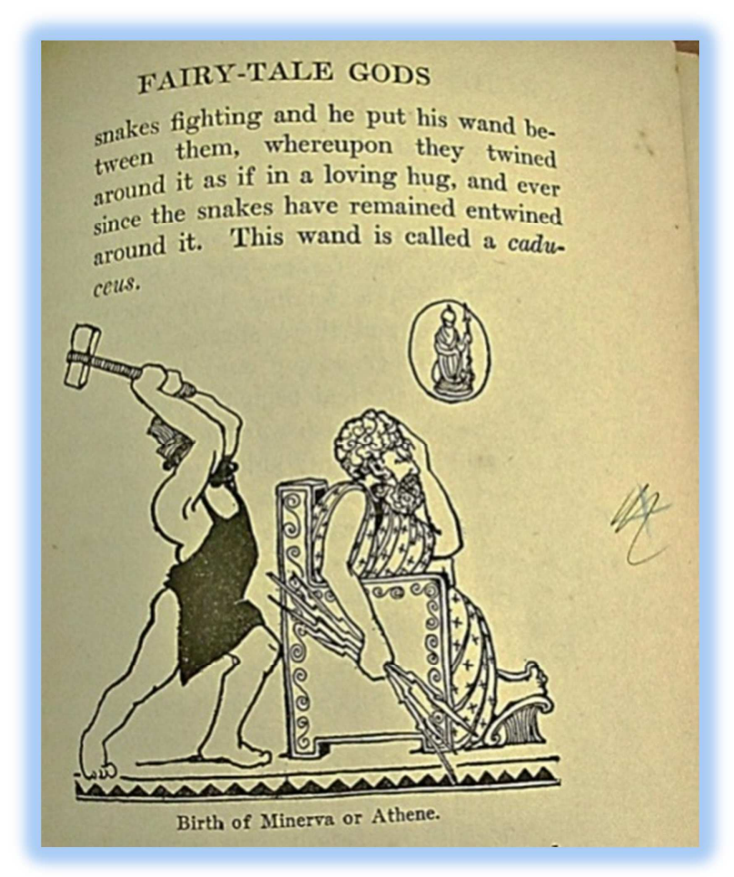

Cruzeta a grafite azul rasurada na leitura de Lobato (Biblioteca Infantil Monteiro Lobato, São Paulo) 
Claudia Amigo Pino e Roberto Zular nos lembram de que, assim como as rasuras trazem em si pistas dos caminhos percorridos pela escritura, o manuscrito não se apresenta como uma sequência, mas como um espaço heterogêneo, no qual diversos tempos convivem e dialogam entre $\mathrm{si}^{25}$.

Em se tratando do manuscrito da História do mundo para as crianças, além das anotações e do recorte de fragmentos, na terceira capa do exemplar, encontram-se duas indicações de datas, "7/1/33" e "4/3/33", acusando dois prováveis períodos de leitura da obra norte-americana:

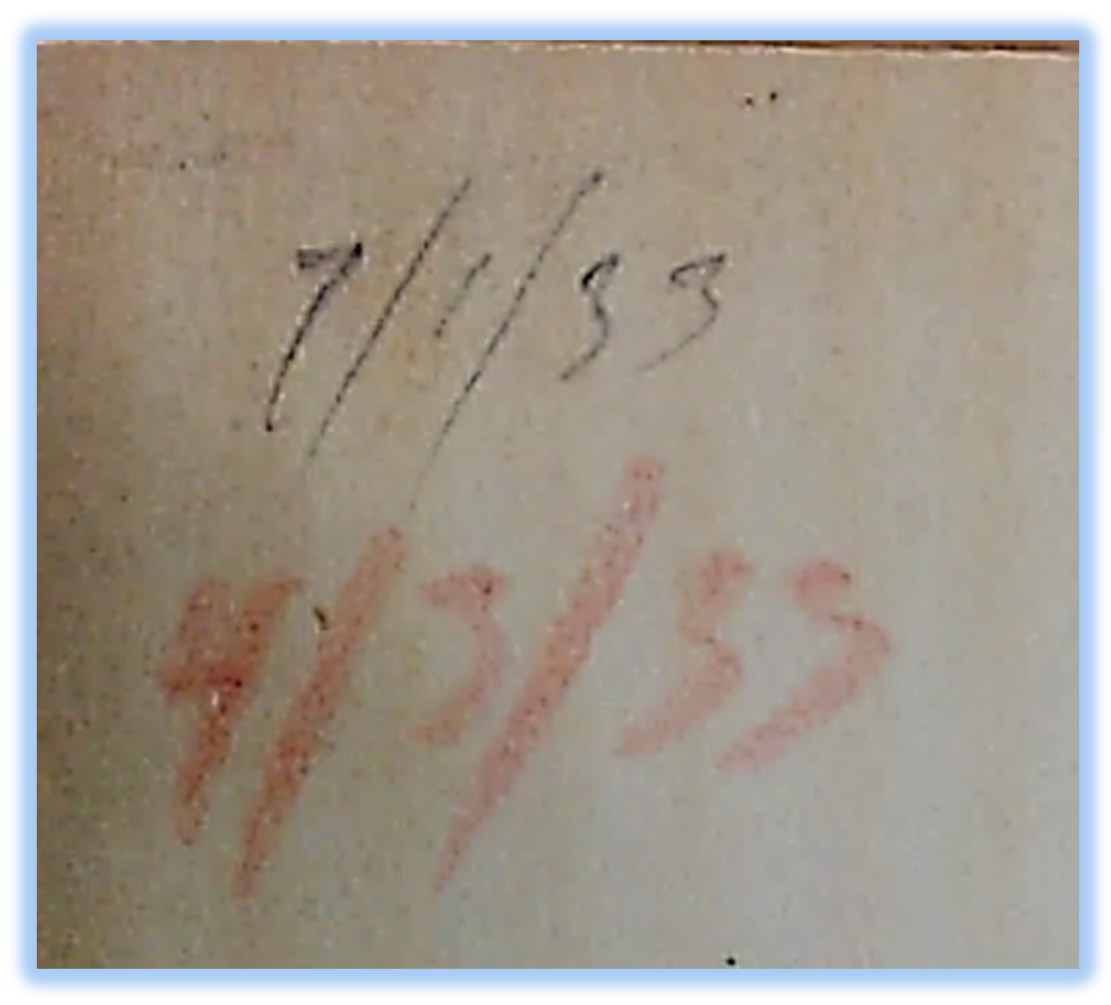

Anotação das datas “7/1/33” e "4/3/33” a grafite e lápis vermelho (Biblioteca Infantil Monteiro Lobato, São Paulo)

${ }^{25}$ PINO, Claudia Amigo; ZULAR, Roberto. Op. cit., p. 28. 
Curiosamente, há no exemplar uma conta a tinta vermelha englobando o ano 3400 a.C, data impressa, por volta da qual teria vivido Menes, o primeiro rei do Egito. Lobato quer saber quantos anos cumpriria Menes em 1934, quando ele renova talvez a leitura para a segunda edição de sua História, nesse ano em 1934. O resultado é 5334 anos!

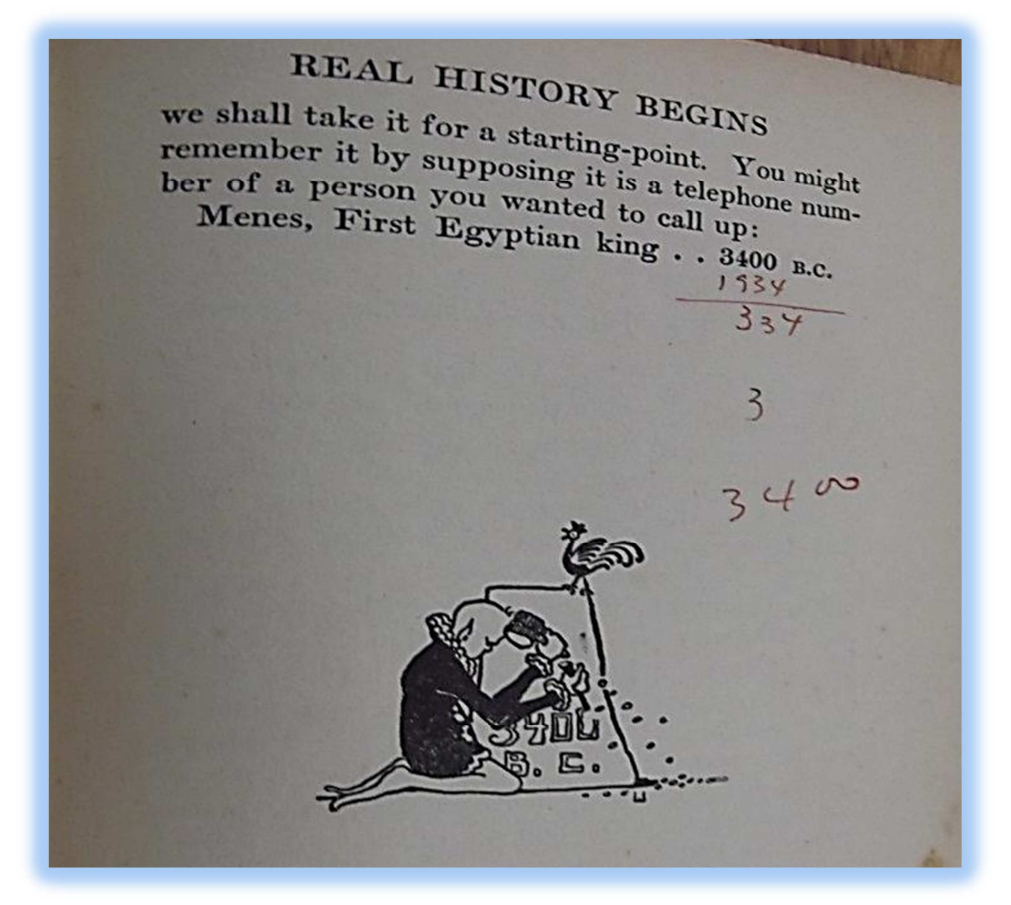

Conta traçada por Lobato a tinta vermelha em seu exemplar do livro de Hillyer (Biblioteca Infantil Monteiro Lobato, São Paulo)

Afora o exemplar encontrado na Biblioteca Infantil Monteiro Lobato, é importante mencionar que, logo no início de História do mundo para as crianças, D. Benta apresenta a matriz da história que contará no Sítio do Picapau Amarelo:

"Dona Benta era uma senhora de muita leitura, que além de ter uma biblioteca de várias centenas de volumes ainda recebia, mandadas por um livreiro da capital, as novidades mais interessantes do momento.

"Uma tarde o correio trouxe-lhe um pacote com duas obras de lindas sobrecapas coloridas - sistema americano. De fato vinham dos Estados Unidos e eram a Child's History of the World e a Child's Geography of the World, de V. M. Hillyer, diretor da Calvert School, de Baltimore.

"Dona Benta leu os livros com cara de quem estava gostando; depois folheou e releu vários volumes da sua biblioteca, que tratavam de assuntos semelhantes, e disse consigo: 'Bela ideia! A história do mundo é um verdadeiro romance que pode muito bem ser contado às crianças. Meninos assim da idade de Pedrinho e Lucia estou certa de que hão de gostar e aproveitar bastante'. 
"E, voltando-se para os dois:

“- Olhem, vamos ter novidade amanhã. Uma história nova que eu vou contar, muito comprida...

“- De urso que vira príncipe? quis saber a Emília?

“-Não. A história que vou contar é a história do mundo, ou universal, como muitos dizem. Fiquem todos avisados e estejam aqui às sete horas em ponto" 26

Escritor, adaptador e personagem se misturam. Dona Benta, grande contadora de histórias, vale-se da leitura de A Child's History of the World e de outros livros de sua biblioteca para narrar a história do mundo, recurso estruturador utilizado por Lobato para adaptar a obra norte-americana. Cabe lembrar que tal estratégia permitiu também que o livro de Hillyer fosse adaptado e atualizado, com o acréscimo de alguns capítulos na $9^{\mathrm{a}}$ e $11^{\mathrm{a}}$ edições e de elementos locais, referentes ao próprio Sítio e ao Brasil ${ }^{27}$.

Sabemos que muitas são as possibilidades de trabalho com o manuscrito de Lobato. Fizemos um recorte apenas para encerrar este múltiplo caminho entre as referências de leitura deixadas nas cartas, as obras restantes da biblioteca do escritor e as notas no exemplar.

\footnotetext{
${ }^{26}$ LOBATO, Monteiro. História do mundo para as crianças. Ed cit., p. 7.

${ }^{27}$ Cf. PALlotTA, Míriam Giberti Páttaro. Uma história meio ao contrário: um estudo sobre História do mundo para as crianças de Monteiro Lobato. Ed. cit., p. 252.
} 


\title{
Considerações finais
}

\begin{abstract}
"Cansado de desanimar, eu não desanimo mais, depois que apanhei a causa dos meus desânimos. Trabalho às ocultas lá no subconsciente. Em quê? Na afinação da lira e na fixação com palavras do que ela apanha. O sonho, sabes qual é - o sonho supremo de todos os artistas. Reduzir o senso estético a um sexto sentido. E então pegar a borboleta!"
\end{abstract}

Monteiro Lobato ${ }^{1}$

Após esse passeio pela biblioteca de Monteiro Lobato, seja ela virtual e hipotética ou apenas vestígios daquilo que foi outrora, é quase que imediato pensar no fazer literário e no trabalho despendido por um escritor na construção de sua obra. Quando se trata da criação, será mesmo que é apenas $1 \%$ de inspiração e os outros $99 \%$ transpiração?

É preciso ter fôlego para ler a quantidade de obras que estão referidas n'A barca de Gleyre. Aliás, ânimo e tempo! Para Lobato, as oportunidades de leitura estavam em qualquer lugar: na vida atribulada de estudante de Ciências Jurídicas e Sociais, na casa do avô visconde, na pacata cidade de Areias em meio à rotina de promotor, no cotidiano de fazendeiro na Buquira, na correria do trabalho como editor e escritor de sucesso, nos Estados Unidos, na Argentina e... na prisão.

Era preciso alimentar-se dos "sumos", "mastigar, ensalivar e engolir"2. Não há como deixar de associar essa premissa à uma visão antropofágica da leitura. A lista de escritores e obras mostra que Lobato não só se ocupou dos clássicos. Seu repertório é extenso e variado, até mesmo os "novos" e os amigos têm espaço no seu cotidiano agitado.

Mas será tão simples assim compreender a criação? Trata-se somente de ler, criar ou recriar? A lição lobatiana é muito maior: saber sentir, saber ver, saber dizer ${ }^{3}$.

Porém, para quem espera encontrar alguma fórmula mágica ou ensinamento ficará feliz ao se deparar com a missiva de 15 de novembro de 1904: "Você me pede um conselho e atrevidamente eu dou o Grande Conselho: seja você mesmo, porque ou somos nós mesmos ou não somos coisa nenhuma." ${ }^{4}$ Não basta apenas ler os grandes da literatura ou possuir um

\footnotetext{
${ }^{1}$ LOBATO, Monteiro. A barca de Gleyre. Ed. cit., p. 78-9. Carta de São Paulo, 15/11/1904.

${ }^{2}$ IDEM, ibidem, p. 106. Carta de Taubaté, 15/03/1906.

${ }^{3}$ IDEM, ibidem, p. 78. Carta de São Paulo, 15/11/1904.

${ }^{4}$ IDEM, ibidem, p. 79. Carta de São Paulo, 15/11/1904.
} 
vocabulário de muitas palavras. Paradoxalmente, é preciso desconstruir para poder construir! Isto é, na valorização da individualidade que hora e outra reitera o aforismo de Nietzsche "Vade mecum? Vade tecum! Queres seguir-me? Segue-te!".

A se julgar pelas cartas, Lobato perece saber que é árduo o caminho trilhado para o desenvolvimento literário:

"E, ademais, estilo é a ultima coisa que nasce num literato - é o dente do
sizo. Quando já está quarentão e já cristalizou uma filosofia própria, quando
possui uma luneta só dele e para ele fabricada sob medida, quando já não é
suscetível da influenciação por mais ninguém, quando alcança a perfeita
maturidade da inteligência, então, sim, aparece o estilo. Como a côr, o sabor
e o perfume duma fruta só aparecem na plena maturação."

Como pudemos ver, muitos são os autores que de algum modo estão presentes na formação de nosso escritor. Sem dúvida, a mais citada das literaturas é a francesa. Se por um lado encontramos um jovem que mergulha nos textos de Daudet, Zola, Balzac, Maupassant, Stendhal, Anatole France, entre outros tantos, vemos também, aos poucos, surgir o Lobato crítico que desaprova a sujeição aos modelos franceses em detrimento da afirmação da identidade nacional.

Assim, recorre aos autores portugueses como forma de recuperar o tempo dedicado às leituras francesas e mergulha nos estudos da língua, acreditando-se defasado. Em Camilo Castelo Branco descobre seu modelo vocabular. Porém, Camilo é muito português de Portugal! Na literatura brasileira, admira-se com Machado de Assis cujo estilo conciso e cuja propriedade vocabular são exemplares para o escritor que está em busca da própria expressão no meio literário.

Os anos passam e Lobato já se tornou um autor consagrado e um editor de sucesso. A Não mais vê a literatura como exercício ou fonte de estudos; o livro é também mercadoria e fonte de renda. Na época em que os negócios editoriais tomam-lhe grande parte do tempo, cresce o relacionamento dele com intelectuais. Os limites entre o leitor e o editor transformam-se: manuscritos chegam às mãos do editor que dedica horas à leitura de algum possível sucesso a ser publicado. Até mesmo os amigos se beneficiam do entusiasmo de Lobato frente às suas editoras. Vale dizer que o editor é também um leitor privilegiado e, em se tratando do criador do Sítio do Picapau Amarelo, um (re)criador, uma vez que Lobato

\footnotetext{
${ }^{5}$ IDEM, ibidem, p. 92. Carta de Taubaté, 15/07/1905.
} 
integra-se ao que lê, sugere alterações nos textos e chega até mesmo a criar uma versão própria, como é o caso da edição que publica das Memórias de um sargento de milícias.

E por falar em suas adaptações, não se pode esquecer o Lobato tradutor, com o qual encerramos a primeira parte da dissertação. Cabe destacar que a divisão dos capítulos foi uma tentativa de organizar os diversos perfis de leitura modificados no decorrer da vida dele. Um estudo como este não pretende apontar quais foram de fato às leituras empreendidas por Lobato, mas rastrear alguns dos prováveis caminhos, preferências e diálogos entre o leitor que desdobra-se em escritor, editor e tradutor. É preciso dizer que, dada à quantidade de referências a escritores n'A barca de Gleyre, acabamos por delimitar nossa análise aos que mais se destacavam na correspondência. Nesse sentido, tentamos indicar outros estudos que dialogam com nossa pesquisa.

Além disso, a visita ao acervo da Biblioteca Infantil e ao CEDAE/Unicamp permitiu que elaborássemos duas listas com os títulos que possivelmente perteceram a biblioteca de Lobato. Em se tratando de um arquivo parcialmente disperso, o trabalho contribui também no sentido de organizar as informações disponíveis e possibilitar que outros pesquisadores utilizem essa coleta de dados para avançar nos estudos lobatianos. Ademais, ao encontrar o exemplar de A Child's History of the World com notas da leitura de Lobato pudemos conhecer um pouco mais dos bastidores da criação de História do mundo para crianças, sem perder de vista a relação Lobato: leitor - adaptador - (re)criador.

Para encerrar esta dissertação, lembramos a última carta d'A barca de Gleyre. Em 23 de junho de 1948, aos sessenta e seis anos de idade, doze dias antes de morrer, Lobato depois de um espasmo vascular, repete para Rangel sua imperiosa necessidade de ler:

"Tenho estado, todo este tempo, privado da leitura - e que falta me faz! A civilização me fez um 'animal que lê', como o porco é um animal que come - e dois meses já sem leitura me vem deixando estranhamente faminto. Imagine Rabicó sem cascas de abóbora por trinta dias!"6

Tão difícil como imaginar Rabicó sem as cascas de abóbora é pensar em Monteiro Lobato sem suas leituras. Quais leituras? - Ah, tantas leituras!

\footnotetext{
${ }^{6}$ IDEM, ibidem, p. 581. Carta de Taubaté, 23/06/1948.
} 


\section{Referências bibliográficas}

ALBIERI, Thaís Mattos. São Paulo-Buenos Aires: A trajetória de Monteiro Lobato na Argentina. In: XIV SEMINÁRIO DE TESES EM ANDAMENTO, 3., novembro de 2008, Campinas (São Paulo). Anais do SETA, Campinas: UNICAMP, 2009, p. 913-923. Disponível em: http://tiny.cc/sax99w. Acesso em 2 out. 2013.

ALBALAT, Antoine. A arte de escrever: ensinada em vinte lições. Tradução de Cândido de Figueiredo. Lisboa: Livraria Clássica, 1948.

ANDRADE, Mário de; BANDEIRA, Manuel. Correspondência Mário de Andrade \& Manuel Bandeira. Organização, introdução e notas de Marcos Antonio de Moraes. São Paulo: Edusp/IEB, 2000.

ANDREOTTI, Azilde Lina. A formação de uma geração: educação para a promoção social e o progresso de país do jornal A Voz da Infância da Biblioteca Infantil Municipal de São Paulo (1936-1950). Tese de Doutorado (orientação: José Luís Sanfelice). Campinas, São Paulo: Universidade Estadual de Campinas, 2004.

ARTUNDO, Patricia. Mário de Andrade e a Argentina: Um país e sua produção cultural como espaço de reflexão. São Paulo: Edusp, 2004.

AZEVEDO, Carmen Lúcia de; CAMARGOS, Márcia; SACCHETTA, Vladimir. Monteiro Lobato: furacão na Botocúndia. São Paulo: SENAC, 1997.

BECKER, Elizamari Rodrigues. Forças motrizes de uma contística pré-modernista: o papel da tradução na obra ficcional de Monteiro Lobato. Tese de Doutorado (orientação: Patrícia Lessa Flores da Cunha). Porto Alegre: Instituto de Letras, Universidade Federal do Rio Grande do Sul, 2006.

BEDÊ, Ana Luiza Reis. Monteiro Lobato e a presença francesa em A barca de Gleyre. Dissertação de Mestrado (orientação: Gilberto Passos). São Paulo: Faculdade de Filosofia, Letras e Ciências Humanas, Universidade de São Paulo, 2004.

BIGNOTTO, Cilza Carla. Novas perspectivas sobre as práticas editoriais de Monteiro Lobato (1918-1925). Tese de Doutorado (orientação Marisa Philbert Lajolo). Campinas, São Paulo: Instituto de Estudos da Linguagem, Universidade Estadual de Campinas, 2007.

BILAC, Olavo. Antologia: Poesias. São Paulo: Martin Claret, 2002. Alma Inquieta. (Coleção a obra-prima de cada autor). Disponível em: http://www.dominiopublico.gov.br/download/texto/bv000285.pdf. Acesso em 17 jul. 2013.

BORGES, Maria Zélia. Exatidão e liberdade na linguagem de Monteiro Lobato. Todas as Letras, $\quad$ v. 1, n.1, São Paulo, 1999. Disponível em: http://www3.mackenzie.br/editora/index.php/tl/article/view/877/630. Acesso em 15 jul. 2012.

BROCA, Brito. A vida literária no Brasil - 1900. 5aed. Rio de Janeiro: José Olympio, Academia Brasileira de Letras, 2005.

BROCA, Brito. O repórter impenitente. Campinas, São Paulo: Editora da Unicamp, 1994. 
BRITO, Regina Helena Pires de. A influência de autores estrangeiros em Lobato e a constituição da Brasilina. Revista do GELNE. v. 4, n. 2, [S.1], 2002. Disponível em: <http://www.gelne.ufc.br/revista_ano4_no2_21.pdf $>$. Acesso em: 11 ago. 2010.

CAMARGOS, Marcia. Juca e Joyce: memórias da neta de Monteiro Lobato/ depoimento a Marcia Camargos. São Paulo: Moderna, 2007.

CANDIDO, Antonio; CARONI, Ítalo; LAUNAY, Michel. O francês instrumental: a experiência da Universidade de São Paulo, São Paulo: Hemus, 1977.

CAVALHEIRO, Edgard (Org.) A correspondência entre Monteiro Lobato e Lima Barreto. Rio de Janeiro: Ministério da Educação e Cultura. Serviço de Documentação, 1955.

CAVALHEIRO, Edgard. Monteiro Lobato: vida e obra. São Paulo: Cia Editora Nacional, 1955.

CHARTIER, Roger. A história cultural: entre práticas e representações. Tradução de Maria Manuela Galhardo. Lisboa: Difel, 1990.

CHIARELLI, Tadeu. Um jeca nos vernissages. São Paulo: EDUSP, 1995.

COELHO, Nelly Novaes. Panorama histórico da literatura infantil/juvenil: das origens indoeuropeias ao Brasil contemporâneo. 4a ed. São Paulo, Ática, 1991.

COSTA, Armando João Dalla. Agroindústria brasileira contemporânea: Inovações organizacionais e transformações tecnológicas na avicultura. Tese de Doutorado (orientação: M. Guy Martinière). Paris, França: Université de la Sorbonne Nouvelle Paris III, 1997. Disponível em: http://www.empresas.ufpr.br/teseajd.pdf Acesso em 14 out. 2013.

DEBUS, Eliane Santana Dias Debus. O leitor, esse conhecido: Monteiro Lobato e a formação de leitores. Tese de Doutorado (orientação: Regina Zilberman). Rio Grande do Sul: Pontifícia Universidade Católica do Rio Grande do Sul, 2001.

DIAZ, José-Luis. "Qual genética para as correspondências". Trad. Cláudio Hiro e Maria Sílvia Ianni Brasalini. Manuscrítica. Revista de Crítica Genética, $\mathrm{n}^{\mathrm{o}}$ 15, São Paulo: Humanitas, 2007.

ENDALÉCIO, Raquel Nunes. A (re) construção do mundo clássico na obra de Monteiro Lobato: fontes e procedimentos. Dissertação de Mestrado (orientação: Marcos Antonio de Moraes). São Paulo, Instituto de Estudos Brasileiros, Universidade de São Paulo, 2013.

FÁVARO, Tatiana. Tão bisbilhoteira quanto Emília. Jornal da Unicamp, Campinas, abril de $2002 . \quad$ Disponível em: http://www.unicamp.br/unicamp/unicamp_hoje/ju/abril2002/unihoje_ju173lobato_pag03.html Acesso em: 08 dez. 2013.

FERREIRA, Aurélio Buarque de Holanda. "Linguagem e estilo de Machado de Assis". In: Linguagem e estilo de Machado de Assis, Eça de Queirós e Simões Lopes Neto. Rio de Janeiro: Academia Brasileira de Letras, 2007. Disponível em: http://www.academia.org.br/abl_e4w/media/Linguagem\%20e\%20Estilo\%20de\%20MachadoEca-Simoes\%20-\%20INTERNET-final.pdf. Acesso em 10 jun. 2012. 
FRANCA, Vanessa Gomes. A literatura infantil/juvenil brasileira na França: Où est Lobatô? Dissertação de Mestrado (orientação: Ofir Bergemann de Aguiar). Goiânia: Faculdade de Letras, Universidade Federal de Goiás, 2007.

GARCIA, Juliana Cristina. Monteiro Lobato: contista e editor. Dissertação de Mestrado (orientação: Alckmar Luiz dos Santos). Florianópolis, Santa Catarina: Universidade Federal de Santa Catarina, 2013.

GOMES, Angela de Castro (org). Escrita de si, escrita da história. Rio de Janeiro: Editora FGV, 2004.

GRÉSILLON, Almuth. Devagar obras. Tradução de Júlio Castañon Guimarães, Rio de Janeiro, Fundação Casa de Rui Barbosa, Ministério da cultura, 1999. In: ZULAR, Roberto. Criação em processo: ensaios de crítica genética. São Paulo: FAPESP/Iluminuras, 2002.

HERVOT. Brigitte Monique. De Flaubert para Maupassant. Lettres Françaises: Revista da Área de Língua e Literatura Francesa. n. 13, Araraquara, São Paulo, Unesp, 2012. Disponível em: http://seer.fclar.unesp.br/lettres/article/view/5310 Acesso em: 5 mar. 2013.

HILLYER, V. M. A Child's History of the World. $1^{\text {a }}$ ed, 15a impressão. Nova York/ Londres: TThe Century Co., 1924. (exemplar conservado no Acervo da Biblioteca Infantil Monteiro Lobato, com notas da leitura de Lobato).

LAJOLO, Marisa. A presença do jornal na vida e na obra de Monteiro Lobato. In: Congresso Brasileiro de Marketing Político - POLITICOM. Memória, espaço e mídia. São Paulo: Editora da Universidade Metodista de São Paulo, UMESP/Mackenzie, 2010. Disponível em: http://www.rehime.com.ar/escritos/documentos/idexalfa/q/queiroz/Quieroz\%20\%20Schaun\%20-\%20Memoria\%20Espaco\%20e\%20midia.pdf. Acesso em: 04 nov. 2013.

LAJOLO, Marisa. De São Paulo ao Aconcágua: uma trajetória latino americana para Monteiro Lobato. Disponível em: http://www.unicamp.br/iel/monteirolobato/outros/limaportugues.pdf Acesso em 10 out. 2013.

LAJOLO, Marisa; CECCANTINI, João Luís. (Org.). Monteiro Lobato, livro a livro. $1^{\mathrm{a}}{ }^{\mathrm{e}}$. São Paulo: UNESP e Imprensa Oficial, 2008.

LOBATO, Monteiro. A barca de Gleyre. Edição coordenada por Arlete Alonso. São Paulo: Globo, 2010.

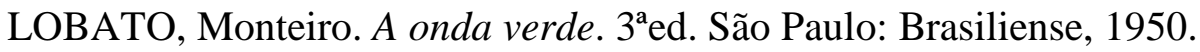

LOBATO, Monteiro. A reforma da natureza. 2aed. São Paulo, Globo, 2010.

LOBATO. Monteiro. Cartas escolhidas. São Paulo: Brasiliense, 1959.

LOBATO, Monteiro. Conferências, artigos e crônicas. Edição coordenada por Cecília Bassarani. São Paulo: Globo, 2010.

LOBATO, Monteiro. História do mundo para as crianças. $1^{\mathrm{a}}$ ed. Biblioteca pedagógica brasileira - Literatura infantil, série I, vol. X. São Paulo: Cia. Editora Nacional, 1933.

LOBATO, Monteiro. Idéias de Jeca Tatu. São Paulo: Brasiliense, 1950.

LOBATO, Monteiro. Mundo da lua e miscelânea. $8^{\mathrm{a} e d . ~ S a ̃ o ~ P a u l o: ~ B r a s i l i e n s e, ~} 1957$. 


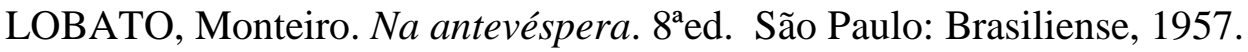

LOBATO, Monteiro. Prefácios e entrevistas. $3^{\mathrm{a} e d .}$ São Paulo: Brasiliense, 1950.

LOBATO, Monteiro. Urupês. Edição coordenada por Arlete Alonso. São Paulo: Globo, 2007.

LOPEZ, Telê Ancona. A criação literária na biblioteca do escritor. Ciência e Cultura, v. 59 n.1, São Paulo, jan./mar. $2007 . \quad$ Disponível em: http://cienciaecultura.bvs.br/scielo.php?pid=S0009-67252007000100016\&script=sci_arttext Acesso em: 5 jun 2012.

MACIEL, Rodrigo Lima. O cenário editorial de Vida e morte de M.J. Gonzaga de Sá, de Lima Barreto. Inventário (PPGLL/UFBA). Salvador, Bahia, UFBA, 12 ed, jan-jul/2013. Disponível em: http://www.inventario.ufba.br/12/O\%20cen\%C3\%A1rio\%20editorial.pdf. Acesso em: 17 set. 2013.

MARTINS, Anna Faedrich. A produção de autoria feminina: Albertina Bertha e a imprensa periódica. Pontos de interrogação - Revista do Programa de Pós-Graduação em Crítica Cultural da Universidade do Estado da Bahia. Alagoinhas, Bahia, v. 2, p. 44-58, n. 1, jan./jun. 2012. Disponível em: http://www.poscritica.uneb.br/revistaponti/arquivos/volume2n1/vol2n1-44-58.pdf. Acesso em: 16 out. 2013.

MARTINS, Milena Ribeiro. Lobato edita Lobato: história das edições dos contos lobatianos. Tese de Doutorado (orientação: Marisa Lajolo). Campinas: Unicamp, 2003.

MONTELLO, Josué. Caminho da fonte. $1^{\mathrm{a}}$ ed. Rio de Janeiro: Instituto Nacional do Livro, 1959.

MORAES, Marcos Antonio de. Epistolografia e Crítica Genética. Ciência e Cultura, São Paulo, v. 59, n.1, Jan./Mar. 2007. Disponível em: http://cienciaecultura.bvs.br/scielo.php?pid=S0009-67252007000100015\&script=sci_arttext. Acesso em: 10 jan. 2012.

NEUSS, Vanete Dutra Santana. Se os leões fossem escultores... na visão de Monteiro Lobato. Sínteses. v. 13, p. 248-275. Campinas, São Paulo: UNICAMP, 2008.

NITRINI, Sandra (org.). Aquém e além mar: relações culturais: Brasil e França. São Paulo: HUCITEC, 2000.

NORONHA, Jovita Maria Gerheim (org.) O pacto autobiográfico: de Rousseau à Internet. Trad. Jovita Maria Gerheim Noronha e Maria Inês Coimbra Guedes. Belo Horizonte: Editora UFMG, 2008.

NUNES, Cassiano. Monteiro Lobato: aplausos e apupos à cultura francesa. Travessia Publicação do Programa de Pós-Graduação em Literatura. n. 16, 17, 18. Florianópolis: UFSC, $1989 . \quad$ Disponível em: http://www.periodicos.ufsc.br/index.php/travessia/article/view/17462/16033 Acesso em: 20 dez. 2012.

PAGLIONE, Eduardo Augusto. Rui Barbosa: Direito e Literatura. Em tempo. Revista da Faculdade de Direito de Marília. v. 4, Marília: Fundação de Ensino Eurípedes Soares da Rocha, ago/2002. http://galileu.fundanet.br/revista/index.php/emtempo/article/viewFile/120/145. 
PALLOTTA, Míriam Giberti Páttaro. Reflexões sobre a prática da tradução para Monteiro Lobato: análise da obra Fábulas. In: XI Congresso Internacional da ABRALIC. Tessituras, Interações, Convergências, 13 a 17 de julho de 2008, São Paulo. Anais do XI Congresso Internacional da ABRALIC. São Paulo: Universidade de São Paulo, 2008. Disponível em: http://www.abralic.org.br/anais/cong2008/AnaisOnline/simposios/pdf/065/MIRIAM_PALLO TTA.pdf Acesso em: 14 nov. 2013.

PALlOTTA, Míriam Giberti Páttaro. Uma história meio ao contrário: um estudo sobre História do mundo para as crianças de Monteiro Lobato. Tese de Doutorado (orientação Carlos Erivany Fantinati). Assis, SP: Universidade Estadual Paulista Júlio de Mesquita Filho, UNESP, 2001.

PASSIANI, Enio. Os duelistas: os confrontos entre Monteiro Lobato e o modernismo na formação do campo literário nacional. In: XXVI Encontro Anual da ANPOCS. GT Pensamento Social no Brasil. Disponível em: http://www.anpocs.org/portal/index.php?option=com_docman\&task=doc_view\&gid=4424\&I temid=317. Acesso em 5 jan. 2013.

PERRONE-MOISÉS, Leyla. Flores da escrivaninha: ensaios. São Paulo: Companhia das Letras, 1990.

PERRONE-MOISÉS, Leyla. Vira e mexe, nacionalismo: paradoxos do nacionalismo literário. São Paulo: Companhia das Letras, 2007.

PINO, Claudia Amigo; ZULAR, Roberto. Escrever sobre escrever: uma introdução crítica à crítica genética. São Paulo: WMF Martins Fontes, 2007.

PROJETO Monteiro Lobato (1882-1948) e outros Modernismos Brasileiros. Disponível em: http://www.unicamp.br/iel/monteirolobato/ Acesso em: 18 out. 2013.

RIBEIRO, Lúcia Amaral de Oliveira. Artifícios e entrega ao exercício da linguagem. Um estudo sobre Flaubert. In: Congresso Internacional da Associação de Pesquisadores em Crítica Genética, X Edição, 2012. Disponível em: http://ebooks.pucrs.br/edipucrs/anais/apcg/edicao10/Lucia.Ribeiro.pdf. Acesso em: 3 nov. 2012.

RIVAS, Pierre. Encontro entre literaturas: França-Portugal-Brasil. Tradução coordenada por Durval Ártico e Maria Letícia Guedes Alcoforado. São Paulo: HUCITEC, 1995.

ROCHA, Pedro Albeirice da. Relembrando Kipling: notas sobre os Jungles Books e o romance Kim. Anthesis: Revista de Letras e Educação da Amazônia Sul-Ocidental. v. 01, p. 225- 236, nº1. Cruzeiro do Sul, Acre: Universidade Federal do Acre, 2012. Disponível em: http://www.periodicoseletronicos.com.br/index.php/anthesis/article/view/66/56. Acesso em: 04 nov. 2013.

SALLES, Cecilia Almeida. Crítica genética: uma (nova) introdução. $2^{\mathrm{a}}$ ed. São Paulo: EDUC, 2000.

SALLES, Cecilia Almeida. Gesto inacabado: processo de criação artística. $2^{\mathrm{a}}$ ed. São Paulo: FAPESP: Annablume, 2004.

SAMPAIO, Márcio. Suplemento Literário de Minas Gerais, Belo Horizonte, ano 19, n. 947, 24 nov. 1984. 
SAMPAIO, Márcio (org.). Suplemento Literário de Minas Gerais, Belo Horizonte, ano 19, n. 948, $1^{\circ}$ dez. 1984.

SANTOS, Geovana Gentili. O papel de Machado de Assis na formação literária de Monteiro Lobato. Miscelânea, Assis, v. 6, jul./nov. 2009. Disponível em: <http://www.assis.unesp.br/posgraduacao/letras/mis/pdf/v6/geovana.pdf $>$. Acesso em: 20 nov. 2011.

SCHMIDT, Rita Terezinha (Org.). Mulheres e literatura: (trans)formando identidades. Porto Alegre: Editora Palotti, 1997.

SILVA, Raquel Afonso da. Entre livros e leituras: Um estudo de cartas de leitores. Tese de Doutorado (orientação: Marisa Philbert Lajolo). Campinas, São Paulo: Instituto de Estudos da Linguagem, Universidade Estadual de Campinas, 2009.

TIN, Emerson. A barca de Gleyre: uma metáfora para a viagem epistolar de Monteiro Lobato e Godofredo Rangel. Intersecções, Revista de estudos sobre práticas discursivas e textuais, n.1, ano 1. Jundiaí, São Paulo, setembro de 2008. Disponível em: http://www.anchieta.br/unianchieta/revistas/interseccoes/pdf/Rev_Inter_Emerson_pdf.pdf Acesso em 22 jan. 2013.

TIN, Emerson. Ficção científica no Brasil: $O$ choque das raças ou O presidente negro, de Monteiro Lobato. Remate de Males. v. 32, $\mathrm{n}^{\mathbf{0}}$ 2, p 293-305. .Campinas/ São Paulo: UNICAMP, jul./dez. 2012. Disponível em: http://www.iel.unicamp.br/revista/index.php/remate/article/view/3401/3400. Acesso em: 12 jan. 2014.

VALE, Fernando Marques do. A obra infantil de Monteiro Lobato: inovações e repercussões. Lisboa: Portugalmundo, 1994.

VAZ, Léo. Páginas vadias. Rio de Janeiro: Livraria José Olympio Editora, 1957.

VIEIRA, Adriana Silene. Viagens de Gulliver ao Brasil (Estudo das adaptações de Gullivers's Travels por Carlos Jansen e por Monteiro Lobato). Tese de Doutorado (orientação: Marisa Philbert Lajolo). Campinas, São Paulo: IEL/UNICAMP, 2004.

WILLEMART, Philippe. Crítica genética e psicanálise. São Paulo: Perspectiva, 2005.

ZORZATO, Lucila Bassan. A Alemanha de Lobato. In: Anais da X Semana de Letras. 70 anos: A FALE FALA. Porto Alegre: EDIPUCRS, 2010. Disponível em: http://ebooks.pucrs.br/edipucrs/anais/Xsemanadeletras/Acesso em: 17 out. 2012.

ZULAR, Roberto (org.) Criação em processo: ensaios de crítica genética. São Paulo: FAPESP/Iluminuras: 2002. 


\section{COMPLEMENTOS}




\section{Complemento A - Autores e obras citados por Monteiro Lobato entre 1903-1917 em A barca de Gleyre ${ }^{1}$}

\begin{tabular}{|c|c|c|c|c|c|}
\hline \multicolumn{6}{|c|}{1903} \\
\hline AUTOR & $\begin{array}{l}\text { PAIS DE } \\
\text { ORIGEM }\end{array}$ & OBRA & PÁGINA & DATA & LOCAL \\
\hline Alexandre Herculano (1810 - 1877) & Portugal & Lendas e narrativa & 25 & Bilhete 1 & São Paulo \\
\hline \multirow{2}{*}{ Alphonse Daudet $(1840-1897)$} & \multirow[t]{2}{*}{ França } & Robert Helmont & 25 & Bilhete 1 & São Paulo \\
\hline & & & 31 & 09/12/1903 & São Paulo \\
\hline \multirow[t]{2}{*}{ Alphonse Lamartine (1790 - 1869) } & \multirow[t]{2}{*}{ França } & & 40 & $28 / 12 / 1903$ & Taubaté \\
\hline & & & 41 & $28 / 12 / 1903$ & Taubaté \\
\hline \multirow[t]{2}{*}{ Coelho Neto (1864 - 1934) } & \multirow[t]{2}{*}{ Brasil } & & 21 & Bilhete 1 & São Paulo \\
\hline & & & 26 & Bilhete 2 & São Paulo \\
\hline \multirow[t]{3}{*}{ Eça de Queiros (1845 - 1900) } & \multirow[t]{3}{*}{ Portugal } & & 34 & 1903 & S. Paulo \\
\hline & & A Cidade e as serras & 41 & $28 / 12 / 1903$ & Taubaté \\
\hline & & $\begin{array}{l}\text { A ilustre casa de } \\
\text { Ramires }\end{array}$ & 41 & $28 / 12 / 1903$ & Taubaté \\
\hline \multirow[t]{2}{*}{ Émile Zola (1840 - 1902) } & \multirow[t]{2}{*}{ França } & & 37 & $13 / 12 / 1903$ & São Paulo \\
\hline & & L'assommoir & 41 & $28 / 12 / 1903$ & Taubaté \\
\hline Ernest Renan (1823 - 1892) & França & & 41 & $28 / 12 / 1903$ & Taubaté \\
\hline \multirow{2}{*}{ Gustave Flaubert $(1821-1880)$} & \multirow[t]{2}{*}{ França } & & 21 & Bilhete 1 & S. Paulo \\
\hline & & & 26 & Bilhete 2 & S. Paulo \\
\hline $\begin{array}{l}\text { Jean-François Champollion (1790 - } \\
\text { 1832) }\end{array}$ & França & & 37 & $13 / 12 / 1903$ & São Paulo \\
\hline Jules Michelet (1798 - 1874) & França & & 41 & $28 / 12 / 1903$ & Taubaté \\
\hline Louis Veuillot (1813 - 1883) & França & & 36 & 1903 & São Paulo \\
\hline Max Nordau (1849 - 1923) & Hungria & & 33 & 1903 & São Paulo \\
\hline Nietzsche $(1844-1900)$ & Alemanha & & 36 & 1903 & São Paulo \\
\hline Voltaire (1694 - 1778) & França & & 33 & 1903 & São Paulo \\
\hline
\end{tabular}

\begin{tabular}{|c|c|c|c|c|c|}
\hline \multicolumn{6}{|c|}{$\begin{array}{ll}1904 \\
\end{array}$} \\
\hline AUTOR & $\begin{array}{l}\text { PAIS DE } \\
\text { ORIGEM }\end{array}$ & OBRA & PÁGINA & DATA & LOCAL \\
\hline Adrien Delpech (1867-1942) & Bélgica & Roman brésilien & 70 & 02/09/1904 & São Paulo \\
\hline Alexandre Herculano (1810 - 1877) & Portugal & & 50 & $20 / 01 / 1904$ & Taubaté \\
\hline \multirow[t]{6}{*}{ Alphonse Daudet (1840 - 1897) } & \multirow[t]{6}{*}{ França } & Sapho & 46 & $04 / 01 / 1904$ & Taubaté \\
\hline & & Jack & 50 & $20 / 01 / 1904$ & Taubaté \\
\hline & & O nababo & 50 & $20 / 01 / 1904$ & Taubaté \\
\hline & & Sapho & 50 & $20 / 01 / 1904$ & Taubaté \\
\hline & & Tartarin de Tarascon & 50 & $20 / 01 / 1904$ & Taubaté \\
\hline & & Le petit chose & 76 & $07 / 11 / 1904$ & São Paulo \\
\hline Alphonse Lamartine (1790 - 1869) & França & & 47 & $04 / 01 / 1904$ & Taubaté \\
\hline Auguste Comte (1798-1857) & França & & 66 & $24 / 08 / 1904$ & São Paulo \\
\hline Breasted (1865 - 1935) & $\begin{array}{l}\text { Estados } \\
\text { Unidos }\end{array}$ & & 51 & $20 / 01 / 1904$ & Taubaté \\
\hline
\end{tabular}

\footnotetext{
${ }^{1}$ Tabela feita para o projeto Era uma vez um autor e seu estilo... (a correspondência de Monteiro Lobato como documento da formação do autor), com bolsa de Iniciação Científica da Fapesp (2007-2009), orientada pela professora Marisa Lajolo, na Universidade Presbiteriana Mackenzie.

Dados a partir de: Lobato, Monteiro. A barca de Gleyre. $7^{\mathrm{a}}$ ed. São Paulo: Brasiliense: 1956.
} 


\begin{tabular}{|c|c|c|c|c|c|}
\hline AUTOR & $\begin{array}{l}\text { PAIS DE } \\
\text { ORIGEM }\end{array}$ & OBRA & PÁGINA & DATA & LOCAL \\
\hline Dostoievsky (1821 - 1881) & Rússia & & 46 & 04/01/1904 & Taubaté \\
\hline Eça de Queiros (1845 - 1900) & Portugal & & 50 & $20 / 01 / 1904$ & Taubaté \\
\hline Elysée Reclus (1830 - 1905) & França & & 51 & $20 / 01 / 1904$ & Taubaté \\
\hline \multirow[t]{4}{*}{ Émile Zola (1840 - 1902) } & \multirow[t]{4}{*}{ França } & Travail & 50 & $20 / 01 / 1904$ & Taubaté \\
\hline & & & 53 & $20 / 01 / 1904$ & Taubaté \\
\hline & & & 54 & $20 / 01 / 1904$ & Taubaté \\
\hline & & & 62 & $16 / 06 / 1904$ & São Paulo \\
\hline Ernest Renan (1823 - 1892) & França & & 47 & $04 / 01 / 1904$ & Taubaté \\
\hline Gaston Maspero (1846 - 1916) & França & & 51 & $20 / 01 / 1904$ & Taubaté \\
\hline Gérard Nerval (1808-1855) & França & & 55 & $20 / 01 / 1904$ & Taubaté \\
\hline \multirow[t]{3}{*}{ Goethe (1749 - 1832) } & \multirow[t]{3}{*}{ Alemanha } & $\begin{array}{l}\text { Os anos de } \\
\text { aprendizado de } \\
\text { Wilhelm Meister }\end{array}$ & 53 & $20 / 01 / 1904$ & Taubaté \\
\hline & & Fausto & 55 & $20 / 01 / 1904$ & Taubaté \\
\hline & & $\begin{array}{l}\text { Os anos de } \\
\text { aprendizado de } \\
\text { Wilhelm Meister }\end{array}$ & 55 & $20 / 01 / 1904$ & Taubaté \\
\hline \multirow[t]{4}{*}{ Graça Aranha (1868 - 1931) } & \multirow[t]{4}{*}{ Brasil } & \multirow[t]{4}{*}{ Canaã } & 45 & $04 / 01 / 1904$ & Taubaté \\
\hline & & & 52 & $20 / 01 / 1904$ & Taubaté \\
\hline & & & 53 & $20 / 01 / 1904$ & Taubaté \\
\hline & & & 54 & $20 / 01 / 1904$ & Taubaté \\
\hline Gustave Aimard (1818- 1883) & França & & 51 & $20 / 01 / 1904$ & Taubaté \\
\hline \multirow[t]{2}{*}{ Gustave Flaubert (1821 - 1880) } & \multirow[t]{2}{*}{ França } & & 49 & $10 / 01 / 1904$ & S. Paulo \\
\hline & & & 66 & $24 / 08 / 1904$ & S. Paulo \\
\hline Gustave Le Bon (1841 - 1931) & França & $\begin{array}{l}\text { Psicologia do } \\
\text { Socialismo }\end{array}$ & 59 & $02 / 06 / 1904$ & São Paulo \\
\hline \multirow[t]{5}{*}{ Guy de Maupassant (1850 - 1893) } & \multirow[t]{5}{*}{ França } & $\mathrm{Bel} A \mathrm{Ami}$ & 46 & $04 / 01 / 1904$ & Taubaté \\
\hline & & Notre coeur & 46 & $04 / 01 / 1904$ & Taubaté \\
\hline & & Mont Oriol & 52 & $20 / 01 / 1904$ & Taubaté \\
\hline & & Pierre et Jean & 52 & $20 / 01 / 1904$ & Taubaté \\
\hline & & Toine & 52 & $20 / 01 / 1904$ & Taubaté \\
\hline $\begin{array}{l}\text { Harriet Beecher Stowe (1811 - } \\
\text { 1896) }\end{array}$ & $\begin{array}{l}\text { Estados } \\
\text { Unidos }\end{array}$ & $\begin{array}{l}\text { A cabana do pai } \\
\text { Tomás }\end{array}$ & 45 & $04 / 01 / 1904$ & Taubaté \\
\hline Herbert Spencer $(1820-1903)$ & Inglaterra & & 51 & $20 / 01 / 1904$ & Taubaté \\
\hline Hippolyte Taine (1828 - 1893) & França & $\begin{array}{l}\text { Historia da literatura } \\
\text { inglesa }\end{array}$ & 58 & $02 / 06 / 1904$ & São Paulo \\
\hline $\begin{array}{l}\text { Jean-François Champollion (1790 - } \\
\text { 1832) }\end{array}$ & França & & 51 & $20 / 01 / 1904$ & Taubaté \\
\hline $\begin{array}{l}\text { Joaquim P. de Oliveira Martins } \\
(1845-1894)\end{array}$ & Portugal & A teoria do socialismo & 54 & $20 / 01 / 1904$ & Taubaté \\
\hline $\begin{array}{l}\text { José Soriano de Sousa } \\
(1833-1895)\end{array}$ & Brasil & & 50 & $20 / 01 / 1904$ & Taubaté \\
\hline Kipling (1865 - 1936) & $\begin{array}{l}\text { Índia } \\
\text { (Bombaim, } \\
\text { colônia } \\
\text { britânica) }\end{array}$ & & 47 & $04 / 01 / 1904$ & Taubaté \\
\hline Lord Byron (1788 - 1824) & Inglaterra & & 58 & $02 / 06 / 1904$ & São Paulo \\
\hline \multirow[t]{3}{*}{ Machado de Assis (1839 - 1908) } & \multirow[t]{3}{*}{ Brasil } & & 46 & $04 / 01 / 1904$ & Taubaté \\
\hline & & & 46 & $04 / 01 / 1904$ & Taubaté \\
\hline & & & 50 & $20 / 01 / 1904$ & Taubaté \\
\hline Madame de Staël (1766-1817) & França & & 45 & $04 / 01 / 1904$ & Taubaté \\
\hline Marcel Prévost (1862 - 1941) & França & & 77 & $07 / 11 / 1904$ & São Paulo \\
\hline
\end{tabular}




\begin{tabular}{|c|c|c|c|c|c|}
\hline AUTOR & $\begin{array}{l}\text { PAIS DE } \\
\text { ORIGEM }\end{array}$ & OBRA & PAGINA & DATA & LOCAL \\
\hline $\begin{array}{l}\text { Michel Eyquem de Montaigne } \\
(1533-1592)\end{array}$ & França & & 50 & $20 / 01 / 1904$ & Taubaté \\
\hline Nicolau Maquiavel (1469 - 1527) & Itália & O príncipe & 55 & $20 / 01 / 1904$ & Taubaté \\
\hline \multirow[t]{6}{*}{ Nietzsche (1844 - 1900) } & \multirow[t]{6}{*}{ Alemanha } & & 56 & $02 / 06 / 1904$ & São Paulo \\
\hline & & & 57 & $02 / 06 / 1904$ & São Paulo \\
\hline & & & 58 & $02 / 06 / 1904$ & São Paulo \\
\hline & & A gaia ciência & 60 & $02 / 06 / 1904$ & São Paulo \\
\hline & & & 65 & $24 / 08 / 1904$ & São Paulo \\
\hline & & Assim falou Zaratustra & 66 & $24 / 08 / 1904$ & São Paulo \\
\hline Pierre Loti $(1850-1923)$ & França & & 46 & $04 / 01 / 1904$ & Taubaté \\
\hline $\begin{array}{l}\text { René de Chateaubriand (1768- } \\
\text { 1848) }\end{array}$ & França & & 53 & $20 / 01 / 1904$ & Taubaté \\
\hline \multirow[t]{2}{*}{ Stendhal (1783 - 1842) } & \multirow[t]{2}{*}{ França } & $\begin{array}{l}\text { La chartreuse de } \\
\text { Parme }\end{array}$ & 54 & $20 / 01 / 1904$ & Taubaté \\
\hline & & Le rouge et le noir & 54 & $20 / 01 / 1904$ & Taubaté \\
\hline \multirow[t]{2}{*}{ Victor Hugo (1802 - 1885) } & \multirow[t]{2}{*}{ França } & & 58 & $02 / 06 / 1904$ & São Paulo \\
\hline & & & 82 & $15 / 11 / 1904$ & São Paulo \\
\hline Volney (1757-1820) & França & & 58 & $02 / 06 / 1904$ & São Paulo \\
\hline \multirow[t]{3}{*}{ William Shakespeare (1564 - 1616) } & Inglaterra & A tempestade & 54 & $20 / 01 / 1904$ & Taubaté \\
\hline & & $\begin{array}{l}\text { Journal de Voyages } \\
\text { (coleção) }\end{array}$ & 51 & $20 / 01 / 1904$ & Taubaté \\
\hline & & Larousse & 51 & $20 / 01 / 1904$ & Taubaté \\
\hline
\end{tabular}

\begin{tabular}{|c|c|c|c|c|c|}
\hline AUTOR & $\begin{array}{l}\text { PAIS DE } \\
\text { ORIGEM }\end{array}$ & OBRA & PÁGINA & DATA & LOCAL \\
\hline Alexandre Dumas & França & & 99 & $13 / 05 / 1905$ & Taubaté \\
\hline Alphonse Daudet (1840 - 1897) & França & & 106 & $19 / 08 / 1905$ & Taubaté \\
\hline Émile Faguet (1847-1916) & França & & 106 & $19 / 08 / 1905$ & Taubaté \\
\hline \multirow[t]{2}{*}{ Émile Zola (1840 - 1902) } & \multirow[t]{2}{*}{ França } & & 91 & $02 / 02 / 1905$ & Taubaté \\
\hline & & Mes haines & 93 & $16 / 02 / 1905$ & Taubaté \\
\hline \multirow[t]{2}{*}{ Ernest Renan (1823 - 1892) } & \multirow[t]{2}{*}{ França } & & 106 & $19 / 08 / 1905$ & Taubaté \\
\hline & & & 107 & 19/08/1905 & Taubaté \\
\hline Gorki (1868 - 1936) & Rússia & & 107 & $19 / 08 / 1905$ & Taubaté \\
\hline \multirow[t]{5}{*}{ Gustave Flaubert (1821 - 1880) } & \multirow[t]{5}{*}{ França } & & 91 & $02 / 02 / 1905$ & Taubaté \\
\hline & & & 92 & $02 / 02 / 1905$ & Taubaté \\
\hline & & Salambô & 99 & $13 / 05 / 1905$ & Taubaté \\
\hline & & & 105 & $19 / 08 / 1905$ & Taubaté \\
\hline & & & 106 & $19 / 08 / 1905$ & Taubaté \\
\hline Guy de Maupassant (1850 - 1893) & França & & 95 & $20 / 02 / 1905$ & Taubaté \\
\hline \multirow[t]{3}{*}{ H. G. Wells (1866 - 1946) } & \multirow[t]{3}{*}{ Inglaterra } & \multirow{2}{*}{$\begin{array}{l}\text { Love and Mr. } \\
\text { Lewisham }\end{array}$} & 111 & $27 / 09 / 1905$ & Taubaté \\
\hline & & & 111 & $17 / 12 / 1905$ & Taubaté \\
\hline & & & 112 & $17 / 12 / 1905$ & Taubaté \\
\hline Honoré de Balzac (1799 - 1850) & França & & 99 & $13 / 05 / 1905$ & Taubaté \\
\hline Julio Verne $(1828-1905)$ & França & & 113 & $17 / 12 / 1905$ & Taubaté \\
\hline $\begin{array}{l}\text { Michel Eyquem de Montaigne } \\
(1533-1592)\end{array}$ & França & & 107 & $19 / 08 / 1905$ & Taubaté \\
\hline Tolstoi $(1828-1910)$ & Rússia & & 107 & $19 / 08 / 1905$ & Taubaté \\
\hline
\end{tabular}




\begin{tabular}{|c|c|c|c|c|c|}
\hline AUTOR & $\begin{array}{l}\text { PAIS DE } \\
\text { ORIGEM }\end{array}$ & OBRA & PAGINA & DATA & LOCAL \\
\hline Alphonse Daudet (1840 - 1897) & França & & 134 & 22/07/1906 & Taubaté \\
\hline Alphonse Karr (1808 - 1890) & França & & 149 & $15 / 12 / 1906$ & Taubaté \\
\hline Anatole France (1844 - 1924) & França & Les dieux ont soif & 137 & $25 / 07 / 1906$ & Taubaté \\
\hline André Theuriet (1833 - 1907) & França & & 120 & $15 / 03 / 1906$ & Taubaté \\
\hline \multirow{3}{*}{$\begin{array}{l}\text { Antoine François Prévost (1697 - } \\
\text { 1763) }\end{array}$} & \multirow[t]{3}{*}{ França } & \multirow{3}{*}{$\begin{array}{l}\text { L'Histoire du chevalier } \\
\text { Des Grieux et de } \\
\text { Manon Lescaut }\end{array}$} & 126 & 1906 & Taubaté \\
\hline & & & 133 & $22 / 07 / 1906$ & Taubaté \\
\hline & & & 134 & $22 / 07 / 1906$ & Taubaté \\
\hline $\begin{array}{l}\text { Bernard Le Bovier de Fontenelle } \\
(1657-1757)\end{array}$ & França & & 149 & $15 / 12 / 1906$ & Taubaté \\
\hline Bernardin Saint-Pierre (1737-1814) & França & & 126 & 1906 & Taubaté \\
\hline Blasco de Ibanez (1867 - 1928) & Espanha & A catedral & 137 & $25 / 07 / 1906$ & Taubaté \\
\hline Bocage (1765-1805) & Portugal & & 149 & 15/12/1906 & Taubaté \\
\hline \multirow{3}{*}{ Charles Dickens (1812 - 1870) } & \multirow[t]{3}{*}{ Inglaterra } & & 143 & 10/09/1906 & Taubaté \\
\hline & & & 149 & 15/12/1906 & Taubaté \\
\hline & & & 154 & 18/01/1906 & Taubaté \\
\hline Dante Alighieri (1265-1321) & Itália & & 120 & $15 / 03 / 1906$ & Taubaté \\
\hline \multirow[t]{2}{*}{ Eça de Queiros (1845 - 1900) } & \multirow[t]{2}{*}{ Portugal } & Cartas de Inglaterra & 123 & 05/05/1906 & Taubaté \\
\hline & & & 123 & 05/05/1906 & Taubaté \\
\hline \multirow[t]{2}{*}{ Edgar Allan Poe (1809 - 1849) } & \multirow{2}{*}{$\begin{array}{l}\text { Estados } \\
\text { Unidos }\end{array}$} & \multirow{2}{*}{$\begin{array}{l}\text { The narrative of Arthur } \\
\text { Gordon Pym }\end{array}$} & 123 & $05 / 05 / 1906$ & Taubaté \\
\hline & & & 149 & 15/12/1906 & Taubaté \\
\hline Élie Metchnikoff (1845 - 1916) & Ucrânia & $\begin{array}{l}\text { Estudos sobre a } \\
\text { natureza humana }\end{array}$ & 148 & $03 / 11 / 1906$ & Taubaté \\
\hline \multirow[t]{2}{*}{ Émile Zola (1840 - 1902) } & \multirow[t]{2}{*}{ França } & Dr. Pascal & 131 & $22 / 07 / 1906$ & Taubaté \\
\hline & & Le rêve & 131 & $22 / 07 / 1906$ & Taubaté \\
\hline Esquilo (525 a.C. - 456 a.C.) & Grécia & $\begin{array}{l}\text { Contos da rainha de } \\
\text { Navarra }\end{array}$ & 123 & $05 / 05 / 1906$ & Taubaté \\
\hline François Rabelais (1494 - 1553) & França & & 123 & $05 / 05 / 1906$ & Taubaté \\
\hline George Sand (1804 -1876) & França & & 131 & $22 / 07 / 1906$ & Taubaté \\
\hline \multirow[t]{2}{*}{ Georges Ohnet (1848 - 1918) } & \multirow[t]{2}{*}{ França } & & 120 & $15 / 03 / 1906$ & Taubaté \\
\hline & & & 128 & 1906 & Taubaté \\
\hline Goethe (1749 - 1832) & Alemanha & & 149 & $15 / 12 / 1906$ & Taubaté \\
\hline \multirow[t]{3}{*}{ Goncourt (1830 - 1870) } & \multirow[t]{3}{*}{ França } & & 126 & 1906 & Taubaté \\
\hline & & & 133 & 22/07/1906 & Taubaté \\
\hline & & & 134 & 22/07/1906 & Taubaté \\
\hline \multirow[t]{2}{*}{ Gustave Flaubert (1821 - 1880) } & \multirow[t]{2}{*}{ França } & & 142 & 10/09/1906 & Taubaté \\
\hline & & Madame Bovary & 143 & 10/09/1906 & Taubaté \\
\hline Guy de Maupassant (1850 - 1893) & França & Miss Harriet & 143 & 10/09/1906 & Taubaté \\
\hline Henry Rider Haggard (1856 - 1925) & Inglaterra & & 143 & 10/09/1906 & Taubaté \\
\hline Homero (aprox. no século VIII a.C) & Grécia & & 120 & $15 / 03 / 1906$ & Taubaté \\
\hline \multirow[t]{4}{*}{ Honoré de Balzac (1799 - 1850) } & \multirow[t]{4}{*}{ França } & & 120 & $15 / 03 / 1906$ & Taubaté \\
\hline & & & 123 & $05 / 05 / 1906$ & Taubaté \\
\hline & & & 149 & $15 / 12 / 1906$ & Taubaté \\
\hline & & & 154 & $18 / 01 / 1907$ & Taubaté \\
\hline \multirow[t]{2}{*}{ Huysmans (1848-1907) } & \multirow[t]{2}{*}{ França } & \multirow[t]{2}{*}{ Là-bas } & 126 & 1906 & Taubaté \\
\hline & & & 131 & $22 / 07 / 1906$ & Taubaté \\
\hline João do Rio (1881 - 1921) & Brasil & As religiões do Rio & 154 & 18/01/1906 & Taubaté \\
\hline John Milton (1608 - 1674) & Inglaterra & & 120 & $15 / 03 / 1906$ & Taubaté \\
\hline John Stuart-Mill (1806 - 1873) & Inglaterra & & 120 & $15 / 03 / 1906$ & Taubaté \\
\hline
\end{tabular}




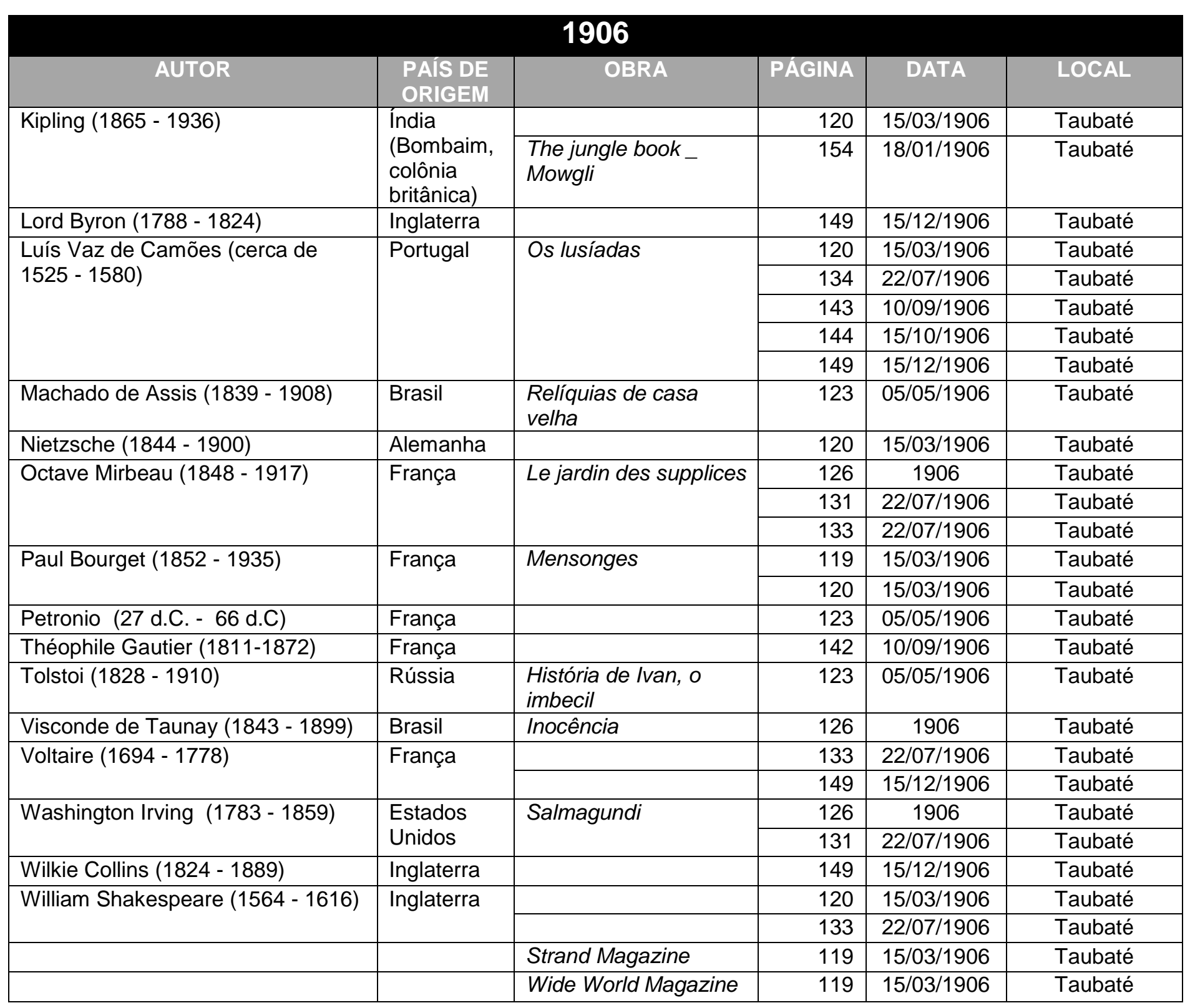

\begin{tabular}{|c|c|c|c|c|c|}
\hline AUTOR & $\begin{array}{l}\text { PAIS DE } \\
\text { ORIGEM }\end{array}$ & OBRA & PÁGINA & DATA & LOCAL \\
\hline \multirow[t]{3}{*}{ Abel Hermant (1862 - 1950) } & \multirow[t]{3}{*}{ França } & $\begin{array}{l}\text { Confession d'un } \\
\text { homme d'aujourd'hui }\end{array}$ & 196 & $22 / 09 / 1907$ & Areias \\
\hline & & La carrière & 196 & $22 / 09 / 1907$ & Areias \\
\hline & & Les transatlantiques & 196 & $22 / 09 / 1907$ & Areias \\
\hline \multirow[t]{2}{*}{ Alphonse Daudet (1840 - 1897) } & \multirow[t]{2}{*}{ França } & & 192 & $09 / 08 / 1907$ & São Paulo \\
\hline & & & 196 & $22 / 09 / 1907$ & Areias \\
\hline
\end{tabular}




\begin{tabular}{|c|c|c|c|c|c|}
\hline AUTOR & $\begin{array}{l}\text { PAIS DE } \\
\text { ORIGEM }\end{array}$ & OBRA & PAGINA & DATA & LOCAL \\
\hline \multirow{8}{*}{ Anatole France (1844 - 1924) } & \multirow[t]{8}{*}{ França } & Crainquebille & 186 & 1907 & Areias \\
\hline & & Histoire comique & 186 & 1907 & Areias \\
\hline & & Le lys rouge & 186 & 1907 & Areias \\
\hline & & Putois & 186 & 1907 & Areias \\
\hline & & Abbé Coignard & 187 & 1907 & Areias \\
\hline & & L'orme du mail & 187 & 1907 & Areias \\
\hline & & $\begin{array}{l}\text { La rotisserie de la } \\
\text { Reine Pedauque }\end{array}$ & 187 & 1907 & Areias \\
\hline & & & 196 & $22 / 09 / 1907$ & Areias \\
\hline Bossuet (1627-1704) & França & & 157 & 02/04/1907 & Taubaté \\
\hline Carlos Malheiro Dias (1875 - 1941) & Portugal & A mulata & 189 & 1907 & Areias \\
\hline Charles Dickens (1812 - 1870) & Inglaterra & & 155 & $26 / 01 / 1907$ & Taubaté \\
\hline \multirow[t]{2}{*}{ Dostoievsky (1821 - 1881) } & \multirow[t]{2}{*}{ Rússia } & Crime e castigo & 193 & $31 / 08 / 1907$ & Areias \\
\hline & & $\begin{array}{l}\text { Recordações da casa } \\
\text { dos mortos }\end{array}$ & 195 & $31 / 08 / 1907$ & Areias \\
\hline Eça de Queiros (1845 - 1900) & Portugal & & 189 & 1907 & Areias \\
\hline Emile Verhaeren (1855 - 1916) & França & & 196 & $22 / 09 / 1907$ & Areias \\
\hline \multirow[t]{2}{*}{ Émile Zola (1840 - 1902) } & \multirow[t]{2}{*}{ França } & & 174 & $07 / 07 / 1907$ & Areias \\
\hline & & & 196 & $22 / 09 / 1907$ & Areias \\
\hline Esquilo (525 a.C. - 456 a.C.) & Grécia & & 174 & $07 / 07 / 1907$ & Areias \\
\hline Fichte (1762 - 1814) & Alemanha & & 158 & 02/04/1907 & Taubaté \\
\hline Goncourt (1830 - 1870) & França & & 196 & $22 / 09 / 1907$ & Areias \\
\hline \multirow[t]{2}{*}{ Gorki (1868 - 1936) } & \multirow[t]{2}{*}{ Rússia } & & 166 & 1907 & Taubaté \\
\hline & & & 195 & $31 / 08 / 1907$ & Areias \\
\hline \multirow[t]{3}{*}{ Gustave Flaubert (1821 - 1880) } & \multirow[t]{3}{*}{ França } & & 185 & $21 / 03 / 1907$ & Areias \\
\hline & & & 186 & 1907 & Areias \\
\hline & & & 196 & 22/09/1907 & Areias \\
\hline \multirow[t]{3}{*}{ Gustave Le Bon (1841 - 1931) } & \multirow[t]{3}{*}{ França } & & 183 & 1907 & Areias \\
\hline & & & 184 & 1907 & Areias \\
\hline & & Evolução da força & 185 & 1907 & Areias \\
\hline Guy de Maupassant (1850 - 1893) & França & & 189 & 1907 & Areias \\
\hline H. G. Wells (1866 - 1946) & Inglaterra & & 174 & $07 / 07 / 1907$ & Areias \\
\hline \multirow[t]{6}{*}{ Hall Caine $(1853-1931)$} & \multirow[t]{6}{*}{ Inglaterra } & \multirow[t]{6}{*}{ O filho pródigo } & 172 & $07 / 07 / 1907$ & Areias \\
\hline & & & 174 & $07 / 07 / 1907$ & Areias \\
\hline & & & 175 & $07 / 07 / 1907$ & Areias \\
\hline & & & 178 & $21 / 07 / 1906$ & Areias \\
\hline & & & 185 & 1907 & Areias \\
\hline & & & 187 & 1907 & Areias \\
\hline Henri Lavedan (1859-1940) & França & & 196 & $22 / 09 / 1907$ & Areias \\
\hline Henry Berstein (1876 - 1953) & França & La Raffale & 196 & $22 / 09 / 1907$ & Areias \\
\hline \multirow[t]{2}{*}{ Herbert Spencer (1820 - 1903) } & \multirow[t]{2}{*}{ Inglaterra } & & 160 & 1907 & Taubaté \\
\hline & & Primeiros princípios & 161 & 1907 & Taubaté \\
\hline \multirow[t]{3}{*}{ Honoré de Balzac (1799 - 1850) } & \multirow[t]{3}{*}{ França } & $\begin{array}{l}\text { La physiologie du } \\
\text { marriage }\end{array}$ & 171 & $15 / 05 / 1907$ & Areias \\
\hline & & & 173 & $07 / 07 / 1907$ & Areias \\
\hline & & & 174 & $07 / 07 / 1907$ & Areias \\
\hline Huysmans (1848-1907) & França & Là-bas & 183 & 1907 & Areias \\
\hline Immanuel Kant (1724 - 1804) & Rússia & & 158 & $02 / 04 / 1907$ & Taubaté \\
\hline Ivan Turgenev (1818 - 1883) & Rússia & & 194 & $31 / 08 / 1907$ & Areias \\
\hline
\end{tabular}




\begin{tabular}{|c|c|c|c|c|c|}
\hline \multicolumn{6}{|c|}{$\begin{array}{ll}1907 & 1907\end{array}$} \\
\hline AUTOR & $\begin{array}{l}\text { PAIS DE } \\
\text { ORIGEM }\end{array}$ & OBRA & PÁGINA & DATA & LOCAL \\
\hline Julia Lopes (1862 - 1934) & Brasil & & 189 & 1907 & Areias \\
\hline Julio Verne (1828 - 1905) & França & & 167 & $14 / 05 / 1907$ & Areias \\
\hline Karl von Hartmann (1842-1906) & Alemanha & & 158 & $02 / 04 / 1907$ & Taubaté \\
\hline \multirow{4}{*}{ Kipling (1865 - 1936) } & \multirow{4}{*}{$\begin{array}{l}\text { Índia } \\
\text { (Bombaim, } \\
\text { colônia } \\
\text { britânica) }\end{array}$} & & 155 & $26 / 01 / 1907$ & Taubaté \\
\hline & & & 174 & $07 / 07 / 1907$ & Areias \\
\hline & & Os inoitos & 176 & $21 / 07 / 1906$ & Areias \\
\hline & & $\begin{array}{l}\text { The jungle book - } \\
\text { Mowgli }\end{array}$ & 197 & $22 / 09 / 1907$ & Areias \\
\hline Léon Frapié (1863 - 1949) & França & & 196 & $22 / 09 / 1907$ & Areias \\
\hline \multirow[t]{3}{*}{ Marcel Prévost (1862 - 1941) } & \multirow[t]{3}{*}{ França } & Jardin secret & 196 & $22 / 09 / 1907$ & Areias \\
\hline & & Lettres à Françoise & 196 & $22 / 09 / 1907$ & Areias \\
\hline & & Lettres de femmes & 196 & $22 / 09 / 1907$ & Areias \\
\hline \multirow{4}{*}{ Mark Twain (1835 - 1910) } & \multirow{4}{*}{$\begin{array}{l}\text { Estados } \\
\text { Unidos }\end{array}$} & & 155 & $26 / 01 / 1907$ & Taubaté \\
\hline & & & 166 & 1907 & Taubaté \\
\hline & & & 175 & $21 / 07 / 1907$ & Areias \\
\hline & & & 176 & $21 / 07 / 1906$ & Areias \\
\hline Maurice Barrès (1862 - 1923) & França & & 196 & $22 / 09 / 1907$ & Areias \\
\hline Nicolau Gogol (1809 - 1852) & Ucrânia & & 195 & $31 / 08 / 1907$ & Areias \\
\hline \multirow{4}{*}{ Nietzsche $(1844-1900)$} & \multirow{4}{*}{ Alemanha } & & 158 & $02 / 04 / 1907$ & Taubaté \\
\hline & & & 161 & 1907 & Taubaté \\
\hline & & & 162 & 1907 & Taubaté \\
\hline & & & 187 & 1907 & Areias \\
\hline Oscar Wilde (1854 - 1900) & Irlanda & $\begin{array}{l}\text { O retrato de Dorian } \\
\text { Gray }\end{array}$ & 201 & $07 / 12 / 1907$ & Areias \\
\hline Paul Hervieu (1857-1915) & França & & 196 & $22 / 09 / 1907$ & Areias \\
\hline Raul Pompéia (1863 - 1895) & Brasil & O ateneu & 175 & $07 / 07 / 1907$ & Areias \\
\hline Restif de la Bretonne (1734-1806) & França & & 181 & 1907 & Areias \\
\hline Rudolf Herman Lotze (1817 - 1881) & Alemanha & & 158 & $02 / 04 / 1907$ & Taubaté \\
\hline Schelling (1775 - 1854) & Alemanha & & 158 & $02 / 04 / 1907$ & Taubaté \\
\hline \multirow[t]{2}{*}{ Tolstoi $(1828-1910)$} & \multirow[t]{2}{*}{ Rússia } & \multirow[t]{2}{*}{ Guerra e paz } & 181 & 1907 & Areias \\
\hline & & & 195 & $31 / 08 / 1907$ & Areias \\
\hline \multirow[t]{2}{*}{ Tristan Bernard (1866 - 1947) } & \multirow[t]{2}{*}{ França } & & 182 & 1907 & Areias \\
\hline & & & 196 & $22 / 09 / 1907$ & Areias \\
\hline Victor Hugo (1802 - 1885) & França & & 174 & $07 / 07 / 1907$ & Areias \\
\hline William Robertson (1721 - 1793) & Escócia & $\begin{array}{l}\text { The history of the } \\
\text { discovery and conquest } \\
\text { of America }\end{array}$ & 200 & $18 / 11 / 1907$ & Areias \\
\hline
\end{tabular}

\begin{tabular}{|l|l|l|r|r|c|}
\hline \multicolumn{2}{|c|}{1908} \\
AUTOR & PAIS DE & OBRA & PAGINA & DATA & LOCAL \\
\hline Alessandro Manzoni (1785-1873) & Itália & & 219 & $15 / 09 / 1908$ & Areias \\
\hline Anatole France $(1844-1924)$ & França & Sur la pierre blanche & 217 & $15 / 09 / 1908$ & Areias \\
\cline { 4 - 6 } & & & 218 & $15 / 09 / 1908$ & Areias \\
\cline { 4 - 6 } & & & 219 & $15 / 09 / 1908$ & Areias \\
\hline Charles Baudelaire (1821-1947) & França & & 206 & $03 / 01 / 1908$ & São Paulo \\
\hline
\end{tabular}




\begin{tabular}{|c|c|c|c|c|c|}
\hline \multicolumn{6}{|c|}{$\begin{array}{ll}1908 & 1908\end{array}$} \\
\hline AUTOR & $\begin{array}{l}\text { PAIS DE } \\
\text { ORIGEM }\end{array}$ & OBRA & PÁGINA & DATA & LOCAL \\
\hline \multirow[t]{3}{*}{ Eça de Queiros (1845 - 1900) } & \multirow[t]{3}{*}{ Portugal } & As farpas & 212 & $10 / 04 / 1908$ & São Paulo \\
\hline & & Uma campanha alegre & 212 & $10 / 04 / 1908$ & São Paulo \\
\hline & & & 212 & $10 / 04 / 1908$ & São Paulo \\
\hline Edmond Rostand (1868 - 1918) & França & Cyrano de Bergerac & 227 & $10 / 12 / 1908$ & Areias \\
\hline Eugenio de Castro (1869-1944) & Portugal & & 206 & $03 / 01 / 1908$ & São Paulo \\
\hline Fenimore Cooper (1789 - 1851) & $\begin{array}{l}\text { Estados } \\
\text { Unidos }\end{array}$ & The water-witch & 226 & $02 / 12 / 1908$ & Areias \\
\hline Fialho d'Almeida (1857 - 1911) & Portugal & & 211 & $10 / 04 / 1908$ & São Paulo \\
\hline Guy de Maupassant $(1850-1893)$ & França & & 208 & $25 / 02 / 1908$ & Areias \\
\hline H. G. Wells (1866 - 1946) & Inglaterra & & 219 & $15 / 09 / 1908$ & Areias \\
\hline \multirow[t]{5}{*}{ Heinrich Heine $(1797-1856)$} & \multirow[t]{5}{*}{ Alemanha } & Atta Troll & 211 & $10 / 04 / 1908$ & São Paulo \\
\hline & & Germania & 211 & $10 / 04 / 1908$ & São Paulo \\
\hline & & Intermezzo & 211 & $10 / 04 / 1908$ & São Paulo \\
\hline & & $\begin{array}{l}\text { Poemas do mar do } \\
\text { norte }\end{array}$ & 211 & $10 / 04 / 1908$ & São Paulo \\
\hline & & Lázaro & 211 & $10 / 04 / 1908$ & São Paulo \\
\hline \multirow[t]{5}{*}{ Homero (aprox. no século VIII a.C) } & \multirow[t]{5}{*}{ Grécia } & & 207 & $03 / 02 / 1908$ & Areias \\
\hline & & Ilíada & 208 & $25 / 02 / 1908$ & Areias \\
\hline & & Odisseia & 208 & $25 / 02 / 1908$ & Areias \\
\hline & & llíada & 209 & $25 / 02 / 1908$ & Areias \\
\hline & & Odisseia & 209 & $25 / 02 / 1908$ & Areias \\
\hline \multirow[t]{3}{*}{ Honoré de Balzac (1799 - 1850) } & \multirow[t]{3}{*}{ França } & \multirow[t]{2}{*}{ Les lys dans la Vallée } & 215 & 1908 & Desconhecido \\
\hline & & & 216 & 1908 & Desconhecido \\
\hline & & Contes drolatiques & 219 & $15 / 09 / 1908$ & Areias \\
\hline \multirow{3}{*}{$\begin{array}{l}\text { Luís Vaz de Camões (cerca de } \\
1525 \text { - 1580) }\end{array}$} & \multirow[t]{3}{*}{ Portugal } & \multirow[t]{3}{*}{ Os lusíadas } & 219 & 1908 & Areias \\
\hline & & & 220 & 1908 & Areias \\
\hline & & & 221 & 1908 & Areias \\
\hline \multirow{3}{*}{ Machado de Assis (1839 - 1908) } & \multirow[t]{3}{*}{ Brasil } & Dom Casmurro & 206 & $03 / 01 / 1908$ & São Paulo \\
\hline & & & 206 & $03 / 01 / 1908$ & São Paulo \\
\hline & & & 223 & $01 / 11 / 1908$ & Areias \\
\hline Manuel Bomfim (1868 - 1932) & Brasil & & 223 & $01 / 11 / 1908$ & Areias \\
\hline Marquês de Sade (1740 - 1814) & França & & 206 & $03 / 01 / 1908$ & São Paulo \\
\hline Paul Verlaine (1844-1896) & França & & 206 & $03 / 01 / 1908$ & São Paulo \\
\hline Restif de la Bretonne (1734-1806) & França & & 208 & $25 / 02 / 1908$ & Areias \\
\hline Rodolfo Teófilo (1853 - 1932) & Brasil & & 223 & $01 / 11 / 1908$ & Areias \\
\hline Silvio Romero (1851 - 1914) & Brasil & & 223 & $01 / 11 / 1908$ & Areias \\
\hline Stendhal (1783 - 1842) & França & & 212 & $10 / 04 / 1908$ & São Paulo \\
\hline Théophile Gautier (1811-1872) & França & & 206 & $03 / 01 / 1908$ & São Paulo \\
\hline Thomas Carlyle (1795 -1881) & Escócia & & 219 & $15 / 09 / 1908$ & Areias \\
\hline Virgilio (70 a.C. - 19 a.C.) & Itália & Eneida & 209 & $25 / 02 / 1908$ & Areias \\
\hline
\end{tabular}




\begin{tabular}{|c|c|c|c|c|c|}
\hline \multicolumn{6}{|c|}{$\begin{array}{ll}1909 & 1909\end{array}$} \\
\hline AUTOR & $\begin{array}{l}\text { PAISS DE } \\
\text { ORIGEM }\end{array}$ & OBRA & PÁGINA & DATA & LOCAL \\
\hline Alberto Rangel $(1871-1945)$ & Brasil & Inferno verde & 253 & $06 / 07 / 1909$ & Areias \\
\hline Alexandre Herculano (1810 - 1877) & Portugal & Lendas e narrativa & 273 & $15 / 09 / 1909$ & Areias \\
\hline \multirow[t]{3}{*}{ Alphonse Daudet (1840 - 1897) } & \multirow{3}{*}{ França } & & 231 & $02 / 01 / 1909$ & São Paulo \\
\hline & & Jack & 264 & $30 / 08 / 1909$ & Areias \\
\hline & & & 265 & $30 / 08 / 1909$ & Areias \\
\hline \multirow[t]{4}{*}{ Antonio Albalat (1856-1935) } & \multirow[t]{4}{*}{ França } & & 259 & $14 / 08 / 1909$ & Areias \\
\hline & & & 262 & $30 / 08 / 1909$ & Areias \\
\hline & & & 275 & $23 / 10 / 1909$ & Areias \\
\hline & & & 279 & $23 / 10 / 1909$ & Areias \\
\hline \multirow[t]{7}{*}{ Caldas Aulete (1826-1878) } & \multirow[t]{7}{*}{ Portugal } & \multirow{7}{*}{$\begin{array}{l}\text { Dicionário } \\
\text { contemporâneo da } \\
\text { língua portuguesa }\end{array}$} & 239 & $07 / 06 / 1909$ & Areias \\
\hline & & & 240 & $07 / 06 / 1909$ & Areias \\
\hline & & & 241 & $07 / 06 / 1909$ & Areias \\
\hline & & & 258 & 14/08/1909 & Areias \\
\hline & & & 260 & $14 / 08 / 1909$ & Areias \\
\hline & & & 262 & $30 / 08 / 1909$ & Areias \\
\hline & & & 270 & $06 / 09 / 1909$ & Areias \\
\hline \multirow{6}{*}{$\begin{array}{l}\text { Camilo Castelo Branco (1825 - } \\
\text { 1890) }\end{array}$} & \multirow[t]{6}{*}{ Portugal } & & 233 & $02 / 01 / 1909$ & São Paulo \\
\hline & & & 241 & $07 / 06 / 1909$ & Areias \\
\hline & & & 249 & $01 / 07 / 1909$ & Areias \\
\hline & & O regicida & 259 & $14 / 08 / 1909$ & Areias \\
\hline & & Eusébio Macário & 273 & $15 / 09 / 1909$ & Areias \\
\hline & & Noites de Insônia & 273 & $15 / 09 / 1909$ & Areias \\
\hline Carlos Malheiro Dias (1875 - 1941) & Portugal & $\begin{array}{l}\text { Paixão de Maria do } \\
\text { Céu }\end{array}$ & 269 & $02 / 09 / 1909$ & Areias \\
\hline Dostoievsky (1821 - 1881) & Rússia & & 281 & $23 / 10 / 1909$ & Areias \\
\hline \multirow[t]{2}{*}{ Edmond Rostand (1868 - 1918) } & \multirow[t]{2}{*}{ França } & Cyrano de Bergerac & 231 & $02 / 01 / 1909$ & São Paulo \\
\hline & & Chanteclair & 249 & $01 / 07 / 1909$ & Areias \\
\hline \multirow{3}{*}{ Euclides da Cunha (1866 - 1909) } & \multirow[t]{3}{*}{ Brasil } & Os sertões & 241 & $07 / 06 / 1909$ & Areias \\
\hline & & & 266 & $01 / 09 / 1909$ & Areias \\
\hline & & & 280 & $23 / 10 / 1909$ & Areias \\
\hline \multirow[t]{2}{*}{ Frei Luís de Sousa (1555 - 1632) } & \multirow[t]{2}{*}{ Portugal } & \multirow[t]{2}{*}{ Anais de D. João III } & 268 & $02 / 09 / 1909$ & Areias \\
\hline & & & 273 & $15 / 09 / 1909$ & Areias \\
\hline Goethe (1749 - 1832) & Alemanha & & 237 & $03 / 05 / 1909$ & Areias \\
\hline Gustave Flaubert (1821 - 1880) & França & & 249 & $01 / 07 / 1909$ & Areias \\
\hline \multirow[t]{10}{*}{ Guy de Maupassant $(1850-1893)$} & \multirow[t]{10}{*}{ França } & & 244 & $27 / 06 / 1909$ & Areias \\
\hline & & Boule de suif & 245 & $27 / 06 / 1909$ & Areias \\
\hline & & Clair de lune & 245 & $27 / 06 / 1909$ & Areias \\
\hline & & La main gauche & 245 & $27 / 06 / 1909$ & Areias \\
\hline & & Mademoiselle Fifi & 245 & $27 / 06 / 1909$ & Areias \\
\hline & & Sur l'eau & 245 & $27 / 06 / 1909$ & Areias \\
\hline & & Clair de lune & 252 & $06 / 07 / 1909$ & Areias \\
\hline & & Sur l'eau & 252 & $06 / 07 / 1909$ & Areias \\
\hline & & & 254 & $22 / 07 / 1909$ & Areias \\
\hline & & & 281 & $23 / 10 / 1909$ & Areias \\
\hline Hall Caine $(1853-1931)$ & Inglaterra & O filho pródigo & 252 & $06 / 07 / 1909$ & Areias \\
\hline Hippolyte Taine (1828 - 1893) & França & & 278 & $23 / 10 / 1909$ & Areias \\
\hline \multirow[t]{2}{*}{ Honoré de Balzac (1799 - 1850) } & \multirow[t]{2}{*}{ França } & Les lys dans la vallée & 245 & $27 / 06 / 1909$ & Areias \\
\hline & & & 281 & $23 / 10 / 1909$ & Areias \\
\hline
\end{tabular}




\begin{tabular}{|c|c|c|c|c|c|}
\hline \multicolumn{6}{|c|}{1909} \\
\hline AUTOR & $\begin{array}{l}\text { PAIS DE } \\
\text { ORIGEM }\end{array}$ & OBRA & PÁGINA & DATA & LOCAL \\
\hline João de Lucena (1549 - 1600) & Portugal & $\begin{array}{l}\text { Historia da vida do } \\
\text { Padre Francisco } \\
\text { Xavier }\end{array}$ & 268 & 02/09/1909 & Areias \\
\hline \multirow[t]{2}{*}{ Kipling (1865 - 1936) } & \multirow{2}{*}{$\begin{array}{l}\text { Índia } \\
\text { (Bombaim, } \\
\text { colônia } \\
\text { britânica) }\end{array}$} & $\begin{array}{l}\text { A mais bela história do } \\
\text { mundo }\end{array}$ & 244 & $27 / 06 / 1909$ & Areias \\
\hline & & $\begin{array}{l}\text { The jungle book } \\
\text { Mowgli }\end{array}$ & 279 & $23 / 10 / 1909$ & Areias \\
\hline Laurent & & História universal & 268 & $02 / 09 / 1909$ & Areias \\
\hline Leconte de Lisle (1818-1894) & França & Os elefantes & 238 & $07 / 06 / 1906$ & Areias \\
\hline \multirow[t]{6}{*}{ Machado de Assis (1839 - 1908) } & \multirow[t]{6}{*}{ Brasil } & Memorial de Aires & 236 & $01 / 03 / 1909$ & Areias \\
\hline & & & 236 & $01 / 03 / 1909$ & Areias \\
\hline & & & 258 & $14 / 08 / 1909$ & Areias \\
\hline & & & 263 & $30 / 08 / 1909$ & Areias \\
\hline & & & 265 & $30 / 08 / 1909$ & Areias \\
\hline & & & 273 & $15 / 09 / 1909$ & Areias \\
\hline Nietzsche (1844 - 1900) & Alemanha & & 246 & $27 / 06 / 1909$ & Areias \\
\hline $\begin{array}{l}\text { Oliver Goldsmith (1728 ou } 1730 \text { - } \\
1774 \text { ) }\end{array}$ & Irlanda & The Vicar of Wakefield & 235 & $01 / 03 / 1909$ & Areias \\
\hline Paul de Saint-Victor (1827 - 1881) & França & & 252 & $06 / 07 / 1909$ & Areias \\
\hline \multirow[t]{5}{*}{$\begin{array}{l}\text { René de Chateaubriand (1768- } \\
\text { 1848) }\end{array}$} & \multirow[t]{5}{*}{ França } & $\begin{array}{l}\text { Memoires d'outre } \\
\text { tombe }\end{array}$ & 275 & $22 / 09 / 1909$ & Areias \\
\hline & & Atala & 276 & $22 / 09 / 1909$ & Areias \\
\hline & & Gênio do cristianismo & 276 & $22 / 09 / 1909$ & Areias \\
\hline & & René & 276 & $22 / 09 / 1909$ & Areias \\
\hline & & & 279 & $23 / 10 / 1909$ & Areias \\
\hline Ruy Barbosa (1849 - 1923) & Brasil & & 274 & $15 / 09 / 1909$ & Areias \\
\hline Sainte Beuve (1804 - 1869) & França & & 278 & $23 / 10 / 1909$ & Areias \\
\hline Stendhal (1783 - 1842) & França & Le rouge et le noir & 245 & $27 / 06 / 1909$ & Areias \\
\hline \multirow{3}{*}{$\begin{array}{l}\text { Thomas Babington Macaulay (1800 } \\
\text { - 1859) }\end{array}$} & \multirow[t]{3}{*}{ Inglaterra } & \multirow{3}{*}{$\begin{array}{l}\text { Critical and historical } \\
\text { essays }\end{array}$} & 247 & $27 / 06 / 1909$ & Areias \\
\hline & & & 261 & $22 / 08 / 1909$ & Areias \\
\hline & & & 278 & $23 / 10 / 1909$ & Areias \\
\hline \multirow[t]{11}{*}{ Tolstoi (1828 - 1910) } & \multirow[t]{11}{*}{ Rússia } & Ressurreição & 235 & $01 / 03 / 1909$ & Areias \\
\hline & & Ana Karenina & 237 & $03 / 05 / 1909$ & Areias \\
\hline & & Ressurreição & 237 & $03 / 05 / 1909$ & Areias \\
\hline & & Ana Karenina & 245 & $27 / 06 / 1909$ & Areias \\
\hline & & Guerra e paz & 245 & $27 / 06 / 1909$ & Areias \\
\hline & & Ana Karenina & 252 & $06 / 07 / 1909$ & Areias \\
\hline & & A Sonata a Kreutzer & 252 & $06 / 07 / 1909$ & Areias \\
\hline & & Ana Karenina & 266 & $30 / 08 / 1909$ & Areias \\
\hline & & Guerra e paz & 267 & $02 / 09 / 1909$ & Areias \\
\hline & & Ana Karenina & 271 & $06 / 09 / 1909$ & Areias \\
\hline & & & 281 & $23 / 10 / 1909$ & Areias \\
\hline Victor Hugo (1802 - 1885) & França & La legende des siècles & 237 & $03 / 05 / 1909$ & Areias \\
\hline Walter Scott $(1771-1832)$ & Escócia & $\begin{array}{l}\text { The bride of } \\
\text { Lammermoor }\end{array}$ & 235 & $01 / 03 / 1909$ & Areias \\
\hline William Shakespeare (1564 - 1616) & Inglaterra & & 237 & $03 / 05 / 1909$ & Areias \\
\hline
\end{tabular}




\begin{tabular}{|c|c|c|c|c|c|}
\hline \multicolumn{6}{|c|}{$\begin{array}{ll}1910 & 1906\end{array}$} \\
\hline AUTOR & $\begin{array}{l}\text { PAIS DE } \\
\text { ORIGEM }\end{array}$ & OBRA & PÁGINA & DATA & LOCAL \\
\hline Alexandre Herculano (1810 - 1877) & Portugal & & 286 & $12 / 01 / 1910$ & Areias \\
\hline Alfred Capus (1852 - 1922) & França & & 286 & $12 / 01 / 1910$ & Areias \\
\hline Almeida Garrett (1799 - 1854) & Portugal & & 286 & $12 / 01 / 1910$ & Areias \\
\hline Anatole France (1844 - 1924) & França & & 293 & $30 / 07 / 1910$ & São Paulo \\
\hline Caillavet (1869 - 1915) & França & & 286 & $12 / 01 / 1910$ & Areias \\
\hline \multirow{4}{*}{$\begin{array}{l}\text { Camilo Castelo Branco (1825 - } \\
\text { 1890) }\end{array}$} & \multirow[t]{4}{*}{ Portugal } & & 285 & $12 / 01 / 1910$ & Areias \\
\hline & & & 286 & $12 / 01 / 1910$ & Areias \\
\hline & & & 287 & $12 / 01 / 1910$ & Areias \\
\hline & & & 290 & $22 / 07 / 1910$ & São Paulo \\
\hline $\begin{array}{l}\text { Charles Maurice Donnay (1859 - } \\
\text { 1945) }\end{array}$ & França & & 286 & $12 / 01 / 1910$ & Areias \\
\hline Edmond Rostand (1868 - 1918) & França & & 286 & $12 / 01 / 1910$ & Areias \\
\hline Émile Zola (1840 - 1902) & França & La joie de vivre & 288 & $20 / 05 / 1910$ & São Paulo \\
\hline Euclides da Cunha (1866 - 1909) & Brasil & À margem da história & 295 & $27 / 09 / 1910$ & Taubaté \\
\hline $\begin{array}{l}\text { Francis Marion Crawford (1854 - } \\
\text { 1909) }\end{array}$ & Itália & & 293 & $30 / 07 / 1910$ & São Paulo \\
\hline Garção & Portugal & & 286 & 12/01/1910 & Areias \\
\hline $\begin{array}{l}\text { Georges de Porto-Riche (1849 - } \\
\text { 1930) }\end{array}$ & França & & 286 & $12 / 01 / 1910$ & Areias \\
\hline Henri Lavedan (1859-1940) & França & & 286 & $12 / 01 / 1910$ & Areias \\
\hline Henry Bataille (1872-1922) & França & & 286 & $12 / 01 / 1910$ & Areias \\
\hline Henry Berstein (1876 - 1953) & França & Le bercail & 286 & $12 / 01 / 1910$ & Areias \\
\hline Herbert Spencer $(1820-1903)$ & Inglaterra & Educação & 291 & $22 / 07 / 1910$ & São Paulo \\
\hline Hippolyte Taine (1828 - 1893) & França & Correspondência & 293 & $30 / 07 / 1910$ & São Paulo \\
\hline Joseph Conrad (1857 - 1924) & Ucrânia & & 294 & $30 / 07 / 1910$ & São Paulo \\
\hline Julio Verne (1828 - 1905) & França & & 285 & $12 / 01 / 1910$ & Areias \\
\hline Laurence Sterne ( 1713 - 1768) & Irlanda & & 293 & $30 / 07 / 1910$ & São Paulo \\
\hline \multirow[t]{3}{*}{ Machado de Assis (1839 - 1908) } & \multirow[t]{3}{*}{ Brasil } & $\begin{array}{l}\text { Memorias póstumas } \\
\text { de Brás Cubas }\end{array}$ & 292 & $30 / 07 / 1910$ & São Paulo \\
\hline & & & 292 & $30 / 07 / 1910$ & São Paulo \\
\hline & & & 293 & $30 / 07 / 1910$ & São Paulo \\
\hline $\begin{array}{l}\text { Manuel Antonio de Almeida (1831 - } \\
\text { 1861) }\end{array}$ & Brasil & $\begin{array}{l}\text { Memorias de um } \\
\text { sargento de milícias }\end{array}$ & 293 & $30 / 07 / 1910$ & São Paulo \\
\hline Octave Mirbeau (1848 - 1917) & França & Le jardin des supplices & 286 & $12 / 01 / 1910$ & Areias \\
\hline Paul Hervieu (1857-1915) & França & & 286 & $12 / 01 / 1910$ & Areias \\
\hline Pierre Loti (1850 - 1923) & França & & 294 & $30 / 07 / 1910$ & São Paulo \\
\hline $\begin{array}{l}\text { Ralph Waldo Emerson (1803 - } \\
\text { 1882) }\end{array}$ & $\begin{array}{l}\text { Estados } \\
\text { Unidos }\end{array}$ & & 293 & $30 / 07 / 1910$ & São Paulo \\
\hline Robert de Flers (1872 - 1927) & França & & 286 & $12 / 01 / 1910$ & Areias \\
\hline Stendhal $(1783-1842)$ & França & & 293 & $30 / 07 / 1910$ & São Paulo \\
\hline Tristan Bernard (1866 - 1947) & França & & 286 & $12 / 01 / 1910$ & Areias \\
\hline William Shakespeare (1564 - 1616) & Inglaterra & & 292 & $30 / 07 / 1910$ & São Paulo \\
\hline Xavier de Maistre (1763 - 1852) & Inglaterra & & 293 & $30 / 07 / 1910$ & São Paulo \\
\hline
\end{tabular}




\begin{tabular}{|c|c|c|c|c|c|}
\hline AUTOR & $\begin{array}{l}\text { PAISS DE } \\
\text { ORIGEM }\end{array}$ & OBRA & PAGINA & DATA & LOCAL \\
\hline Anatole France (1844 - 1924) & França & & 315 & 10/10/1911 & Taubaté \\
\hline Aretino $(1492-1556)$ & Itália & & 311 & $07 / 08 / 1911$ & Taubaté \\
\hline Bernardo Guimarães (1825 - 1884) & Brasil & & 316 & $09 / 11 / 1911$ & Taubaté \\
\hline Conan Doyle (1859 - 1930) & Escócia & & 301 & $04 / 04 / 1911$ & Taubaté \\
\hline D'Annunzio (1863 - 1938) & Itália & O inocente & 311 & $07 / 08 / 1911$ & Taubaté \\
\hline \multirow[t]{3}{*}{ Euclides da Cunha (1866 - 1909) } & \multirow[t]{3}{*}{ Brasil } & & 312 & $11 / 09 / 1911$ & Taubaté \\
\hline & & & 313 & $11 / 09 / 1911$ & Taubaté \\
\hline & & & 314 & $11 / 09 / 1911$ & Taubaté \\
\hline Honoré de Balzac (1799 - 1850) & França & $\begin{array}{l}\text { La physiologie } d u \\
\text { marriage }\end{array}$ & 319 & $10 / 12 / 1911$ & Fazenda \\
\hline Machado de Assis (1839-1908) & Brasil & & 300 & $04 / 04 / 1911$ & Taubaté \\
\hline Marquês de Sade (1740 - 1814) & França & & 311 & $07 / 08 / 1911$ & Taubaté \\
\hline Théodore de Banville (1823 - 1891) & França & Lanterna mágica & 317 & $09 / 11 / 1911$ & Taubaté \\
\hline
\end{tabular}

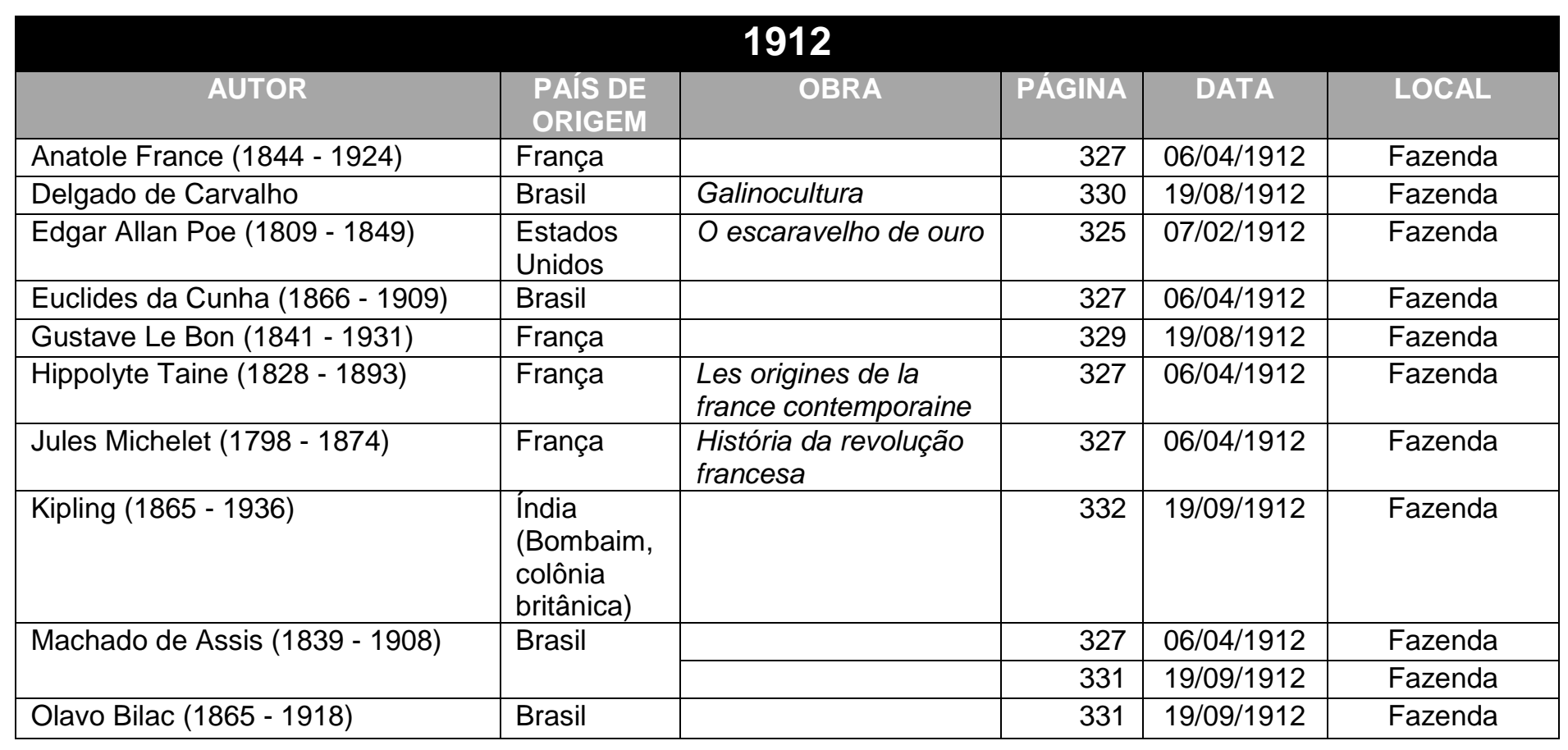




\begin{tabular}{|c|c|c|c|c|c|}
\hline AUTOR & $\begin{array}{l}\text { PAIS DE } \\
\text { ORIGEM }\end{array}$ & OBRA & PÁGINA & DATA & LOCAL \\
\hline \multirow[t]{2}{*}{ Almeida Garrett (1799 - 1854) } & \multirow[t]{2}{*}{ Portugal } & O arco de Sant'Ana & 337 & $01 / 03 / 1913$ & São Paulo \\
\hline & & $\begin{array}{l}\text { Viagens na minha } \\
\text { terra }\end{array}$ & 337 & $01 / 03 / 1913$ & São Paulo \\
\hline \multirow[t]{2}{*}{ Alphonse Daudet (1840 - 1897) } & \multirow[t]{2}{*}{ França } & Jack & 342 & $09 / 05 / 1913$ & São Paulo \\
\hline & & & 342 & $09 / 05 / 1913$ & São Paulo \\
\hline $\begin{array}{l}\text { Ernst Theodor Hoffmann (1776 - } \\
\text { 1822) }\end{array}$ & Rússia & Contos fantásticos & 337 & $01 / 03 / 1913$ & São Paulo \\
\hline François Rabelais (1494 - 1553) & França & & 341 & $09 / 05 / 1913$ & São Paulo \\
\hline Gustave Flaubert (1821 - 1880) & França & & 339 & $21 / 04 / 1913$ & São Paulo \\
\hline Henri Fabre (1823 - 1915) & França & & 340 & $09 / 05 / 1913$ & São Paulo \\
\hline Hippolyte Taine (1828 - 1893) & França & & 340 & 09/05/1913 & São Paulo \\
\hline Marquês de Sade $(1740-1814)$ & França & & 341 & $09 / 05 / 1913$ & São Paulo \\
\hline Nietzsche $(1844-1900)$ & Alemanha & & 339 & $21 / 04 / 1913$ & São Paulo \\
\hline \multirow[t]{2}{*}{ Paul de Saint-Victor (1827 - 1881) } & França & & 340 & $09 / 05 / 1913$ & São Paulo \\
\hline & & $\begin{array}{l}\text { Biblioteca } \\
\text { internacional de obras } \\
\text { célebres }\end{array}$ & 340 & $09 / 05 / 1913$ & São Paulo \\
\hline
\end{tabular}

\begin{tabular}{|c|c|c|c|c|c|}
\hline AUTOR & $\begin{array}{l}\text { PAIS DE } \\
\text { ORIGEM }\end{array}$ & OBRA & PAGINA & DATA & LOCAL \\
\hline Antonio Albalat (1856-1935) & França & & 365 & $30 / 10 / 1914$ & Fazenda \\
\hline \multirow[t]{3}{*}{ Émile Zola (1840 - 1902) } & \multirow[t]{3}{*}{ França } & & 354 & $15 / 05 / 1914$ & Fazenda \\
\hline & & & 355 & $15 / 05 / 1914$ & Fazenda \\
\hline & & La joie de vivre & 360 & $07 / 06 / 1914$ & Fazenda \\
\hline Fagundes Varela (1841 - 1875) & Brasil & & 364 & $20 / 10 / 1914$ & Fazenda \\
\hline \multirow[t]{3}{*}{ Honoré de Balzac (1799 - 1850) } & \multirow[t]{3}{*}{ França } & & 352 & $15 / 05 / 1914$ & Fazenda \\
\hline & & La cousine Bette & 354 & $15 / 05 / 1914$ & Fazenda \\
\hline & & Cesar Birotteau & 355 & $15 / 05 / 1914$ & Fazenda \\
\hline José de Alencar (1829 - 1877) & Brasil & & 364 & $20 / 10 / 1914$ & Fazenda \\
\hline Julia Lopes (1862 - 1934) & Brasil & & 364 & 20/10/1914 & Fazenda \\
\hline Marquês de Sade (1740 - 1814) & França & & 359 & $07 / 06 / 1914$ & Fazenda \\
\hline Olavo Bilac (1865 - 1918) & Brasil & & 361 & $07 / 06 / 1914$ & Fazenda \\
\hline Théophile Gautier (1811-1872) & França & & 348 & $03 / 04 / 1914$ & Fazenda \\
\hline
\end{tabular}




\begin{tabular}{|c|c|c|c|c|c|}
\hline AUTOR & $\begin{array}{l}\text { PAIS DE } \\
\text { ORIGEM }\end{array}$ & OBRA & PÁGINA & DATA & LOCAL \\
\hline Alberto Torres (1865-1917) & Brasil & & 38 & $30 / 06 / 1915$ & Santos \\
\hline \multirow[t]{2}{*}{ Alexandre Herculano (1810 - 1877) } & \multirow[t]{2}{*}{ Portugal } & Lendas e narrativas & 12 & $23 / 01 / 1915$ & Fazenda \\
\hline & & Eurico, o presbítero & 12 & $23 / 01 / 1915$ & Fazenda \\
\hline Alphonse Lamartine (1790 - 1869) & França & $\begin{array}{l}\text { Vita de Benevenuto } \\
\text { Cellini (adaptação) }\end{array}$ & 39 & $30 / 06 / 1915$ & Santos \\
\hline \multirow[t]{2}{*}{ Aluísio Azevedo (1857-1913) } & \multirow[t]{2}{*}{ Brasil } & Casa de pensão & 38 & $30 / 06 / 1915$ & Santos \\
\hline & & & 55 & $23 / 10 / 1915$ & Fazenda \\
\hline \multirow[t]{3}{*}{ Anatole (1844 - 1924) } & \multirow[t]{3}{*}{ França } & \multirow{2}{*}{$\begin{array}{l}\text { O crime de Silvestre } \\
\text { Bonnard }\end{array}$} & 16 & $03 / 02 / 1915$ & Fazenda \\
\hline & & & 17 & $06 / 02 / 1915$ & Fazenda \\
\hline & & Ilha dos pinguins & 46 & $04 / 08 / 1915$ & S. Paulo \\
\hline Antonio Vieira (1608-1697) & Portugal & & 55 & $23 / 10 / 1915$ & Fazenda \\
\hline Araripe Junior (1848-1911) & Brasil & & 47 & $04 / 08 / 1915$ & S. Paulo \\
\hline Benevenuto Cellini (1500-1571) & Itália & $\begin{array}{l}\text { Vita de Benevenuto } \\
\text { Cellini }\end{array}$ & 38 & $30 / 06 / 1915$ & Santos \\
\hline Buffon (1707-1788) & França & & 16 & $03 / 02 / 1915$ & Fazenda \\
\hline Caldas Aulete (1826-1878) & Portugal & $\begin{array}{l}\text { Dicionário } \\
\text { contemporâneo da } \\
\text { língua portuguesa } \\
\end{array}$ & 39 & $03 / 07 / 1915$ & Ponta da Praia \\
\hline \multirow{26}{*}{$\begin{array}{l}\text { Camilo Castelo Branco (1825 - } \\
\text { 1890) }\end{array}$} & \multirow{26}{*}{ Portugal } & & 7 & $16 / 01 / 1915$ & Caçapava \\
\hline & & Vinte horas de liteira & 8 & $16 / 01 / 1915$ & Caçapava \\
\hline & & $\begin{array}{l}\text { Cancioneiro alegre de } \\
\text { poetas portugueses e } \\
\text { brasileiros }\end{array}$ & 10 & $16 / 01 / 1915$ & Caçapava \\
\hline & & Amor de salvação & 10 & $16 / 01 / 1915$ & Caçapava \\
\hline & & & 10 & $23 / 01 / 1915$ & Fazenda \\
\hline & & Vinte horas de liteira & 11 & $23 / 01 / 1915$ & Fazenda \\
\hline & & & 12 & $23 / 01 / 1915$ & Fazenda \\
\hline & & & 12 & $30 / 01 / 1915$ & Fazenda \\
\hline & & & 13 & $30 / 01 / 1915$ & Fazenda \\
\hline & & & 17 & $06 / 02 / 1915$ & Fazenda \\
\hline & & & 18 & $06 / 02 / 1915$ & Fazenda \\
\hline & & & 24 & $30 / 03 / 1915$ & Fazenda \\
\hline & & & 25 & 30/03/1915 & Fazenda \\
\hline & & Agulha em palheiro & 25 & $30 / 03 / 1915$ & Fazenda \\
\hline & & & 26 & $30 / 03 / 1915$ & Fazenda \\
\hline & & Boémia do Espírito & 26 & $30 / 03 / 1915$ & Fazenda \\
\hline & & & 44 & $01 / 08 / 1915$ & S. Paulo \\
\hline & & & 46 & $04 / 08 / 1915$ & S. Paulo \\
\hline & & & 50 & $30 / 09 / 1915$ & Fazenda \\
\hline & & \multirow[t]{2}{*}{ Boémia do Espírito } & 52 & $30 / 09 / 1915$ & Fazenda \\
\hline & & & 53 & $30 / 09 / 1915$ & Fazenda \\
\hline & & & 54 & $30 / 09 / 1915$ & Fazenda \\
\hline & & & 55 & $23 / 10 / 1915$ & Fazenda \\
\hline & & & 56 & $23 / 10 / 1915$ & Fazenda \\
\hline & & & 60 & 07/12/1915 & Fazenda \\
\hline & & A caveira da mártir & 60 & 07/12/1915 & Fazenda \\
\hline $\begin{array}{l}\text { Carlos Eduardo Pereira (1855- } \\
\text { 1922) }\end{array}$ & Brasil & Gramática & 50 & $30 / 09 / 1915$ & Fazenda \\
\hline Charles Dickens (1812 - 1870) & Inglaterra & & 45 & $04 / 08 / 1915$ & S. Paulo \\
\hline
\end{tabular}




\begin{tabular}{|c|c|c|c|c|c|}
\hline AUTOR & $\begin{array}{l}\text { PAIS DE } \\
\text { ORIGEM }\end{array}$ & OBRA & PAGINA & DATA & LOCAL \\
\hline \multirow{4}{*}{ Coelho Neto (1864 - 1934) } & \multirow[t]{4}{*}{ Brasil } & & 11 & 23/01/1915 & Fazenda \\
\hline & & O turbilhão & 29 & $17 / 05 / 1915$ & Fazenda \\
\hline & & & 31 & $20 / 05 / 1915$ & Fazenda \\
\hline & & & 44 & $01 / 08 / 1915$ & S. Paulo \\
\hline \multirow[t]{11}{*}{ Eça de Queirós (1845 - 1900) } & \multirow[t]{11}{*}{ Portugal } & $\begin{array}{l}\text { A ilustre casa de } \\
\text { Ramires }\end{array}$ & 12 & $23 / 01 / 1915$ & Fazenda \\
\hline & & & 14 & $30 / 01 / 1915$ & Fazenda \\
\hline & & & 19 & $12 / 02 / 1915$ & Fazenda \\
\hline & & & 25 & $30 / 03 / 1915$ & Fazenda \\
\hline & & & 26 & $30 / 03 / 1915$ & Fazenda \\
\hline & & & 50 & $30 / 09 / 1915$ & Fazenda \\
\hline & & & 57 & $23 / 10 / 1915$ & Fazenda \\
\hline & & Os maias & 58 & $07 / 12 / 1915$ & Fazenda \\
\hline & & $\begin{array}{l}\text { A ilustre casa de } \\
\text { Ramires }\end{array}$ & 58 & $07 / 12 / 1915$ & Fazenda \\
\hline & & & 59 & $07 / 12 / 1915$ & Fazenda \\
\hline & & & 60 & $07 / 12 / 1915$ & Fazenda \\
\hline Edgar Allan Poe (1809 - 1849) & $\begin{array}{l}\text { Estados } \\
\text { Unidos }\end{array}$ & & 41 & $15 / 07 / 1915$ & Santos \\
\hline \multirow[t]{5}{*}{ Edmundo d'Amicis (1846-1908) } & \multirow[t]{5}{*}{ Itália } & Cuore & 37 & $30 / 06 / 1915$ & Santos \\
\hline & & La vita militare & 37 & $30 / 06 / 1915$ & Santos \\
\hline & & L'idioma gentile & 37 & $30 / 06 / 1915$ & Santos \\
\hline & & Constantinopla & 37 & $30 / 06 / 1915$ & Santos \\
\hline & & & 38 & $30 / 06 / 1915$ & Santos \\
\hline \multirow[t]{3}{*}{ Émile Zola (1840 - 1902) } & \multirow[t]{3}{*}{ França } & & 13 & $30 / 01 / 1915$ & Fazenda \\
\hline & & & 55 & $23 / 10 / 1915$ & Fazenda \\
\hline & & & 60 & $07 / 12 / 1915$ & Fazenda \\
\hline \multirow[t]{4}{*}{ Euclides da Cunha (1866 - 1909) } & \multirow[t]{4}{*}{ Brasil } & & 38 & $30 / 06 / 1915$ & Santos \\
\hline & & & 50 & $30 / 09 / 1915$ & Fazenda \\
\hline & & & 51 & $30 / 09 / 1915$ & Fazenda \\
\hline & & & 60 & $07 / 12 / 1915$ & Fazenda \\
\hline \multirow[t]{11}{*}{ Fialho d'Almeida (1857 - 1911) } & \multirow[t]{11}{*}{ Portugal } & & 18 & $06 / 02 / 1915$ & Fazenda \\
\hline & & & 19 & $12 / 02 / 1915$ & Fazenda \\
\hline & & & 22 & $12 / 02 / 1915$ & Fazenda \\
\hline & & & 24 & $30 / 03 / 1915$ & Fazenda \\
\hline & & & 25 & $30 / 03 / 1915$ & Fazenda \\
\hline & & & 50 & $30 / 09 / 1915$ & Fazenda \\
\hline & & & 51 & $30 / 09 / 1915$ & Fazenda \\
\hline & & & 52 & $30 / 09 / 1915$ & Fazenda \\
\hline & & & 53 & $30 / 09 / 1915$ & Fazenda \\
\hline & & & 55 & $23 / 10 / 1915$ & Fazenda \\
\hline & & & 60 & $07 / 12 / 1915$ & Fazenda \\
\hline Gerhart Hauptmann (1862-1946) & Alemanha & & 60 & $07 / 12 / 1915$ & Fazenda \\
\hline
\end{tabular}




\begin{tabular}{|c|c|c|c|c|c|}
\hline AUTOR & $\begin{array}{l}\text { PAIS DE } \\
\text { ORIGEM }\end{array}$ & OBRA & PAGINA & DATA & LOCAL \\
\hline \multirow{10}{*}{$\begin{array}{l}\text { Godofredo de Moura Rangel (1884- } \\
\text { 1951) }\end{array}$} & \multirow[t]{10}{*}{ Brasil } & \multirow[t]{10}{*}{ Vida ociosa } & 17 & $06 / 02 / 1915$ & Fazenda \\
\hline & & & 19 & $06 / 02 / 1915$ & Fazenda \\
\hline & & & 23 & $30 / 03 / 1915$ & Fazenda \\
\hline & & & 32 & $03 / 06 / 1915$ & Fazenda \\
\hline & & & 38 & $30 / 06 / 1915$ & Fazenda \\
\hline & & & 40 & $03 / 07 / 1915$ & Ponta da Praia \\
\hline & & & 44 & $01 / 08 / 1915$ & S. Paulo \\
\hline & & & 45 & $04 / 08 / 1915$ & S. Paulo \\
\hline & & & 46 & $04 / 08 / 1915$ & S. Paulo \\
\hline & & & 46 & $07 / 09 / 1915$ & S. Paulo \\
\hline \multirow[t]{2}{*}{ Goncourt (1830 - 1870) } & \multirow[t]{2}{*}{ França } & & 28 & $03 / 04 / 1915$ & Fazenda \\
\hline & & & 60 & $07 / 12 / 1915$ & Fazenda \\
\hline Gorki (1868 - 1936) & Rússia & & 42 & $15 / 07 / 1915$ & Santos \\
\hline Graça Aranha (1868 - 1931) & Brasil & & 54 & $23 / 10 / 1915$ & Fazenda \\
\hline \multirow[t]{4}{*}{ Gustave Flaubert $(1821-1880)$} & \multirow[t]{4}{*}{ França } & & 26 & $30 / 03 / 1915$ & Fazenda \\
\hline & & & 27 & $03 / 04 / 1915$ & Fazenda \\
\hline & & & 28 & $03 / 04 / 1915$ & Fazenda \\
\hline & & & 60 & $07 / 12 / 1915$ & Fazenda \\
\hline Guy de Maupassant (1850 - 1893) & França & & 24 & $30 / 03 / 1915$ & Fazenda \\
\hline $\begin{array}{l}\text { Hermann Sudermann } \\
(1857-1928)\end{array}$ & Alemanha & & 60 & $07 / 12 / 1915$ & Fazenda \\
\hline Homero (aprox. no século VIII a.C) & Grécia & & 55 & $23 / 10 / 1915$ & Fazenda \\
\hline Ibsen $(1828-1906)$ & Noruega & & 41 & $15 / 07 / 1915$ & Santos \\
\hline \multirow[t]{3}{*}{ João do Rio (1881 - 1921) } & \multirow[t]{3}{*}{ Brasil } & & 14 & $30 / 01 / 1915$ & Fazenda \\
\hline & & & 15 & $30 / 01 / 1915$ & Fazenda \\
\hline & & & 54 & $30 / 09 / 1915$ & Fazenda \\
\hline John Milton (1608 - 1674) & Inglaterra & & 47 & $04 / 08 / 1915$ & S. Paulo \\
\hline \multirow[t]{3}{*}{ José Antonio Nogueira } & \multirow[t]{3}{*}{ Brasil } & Os deuses morrem & 41 & $15 / 07 / 1915$ & Santos \\
\hline & & \multirow[t]{2}{*}{ Amor imortal } & 47 & $07 / 09 / 1915$ & S. Paulo \\
\hline & & & 48 & $21 / 09 / 1915$ & S. Paulo \\
\hline Julia Lopes (1862 - 1934) & Brasil & & 38 & $30 / 06 / 1915$ & Santos \\
\hline Kipling (1865 - 1936) & $\begin{array}{l}\text { Índia } \\
\text { (Bombaim, } \\
\text { colônia } \\
\text { britânica) }\end{array}$ & & 45 & $04 / 08 / 1915$ & S. Paulo \\
\hline Laurence Sterne ( 1713 - 1768) & Irlanda & & 56 & $23 / 10 / 1915$ & Fazenda \\
\hline $\begin{array}{l}\text { Luiz Napoleão Chernoviz (1812- } \\
\text { 1881) }\end{array}$ & Polônia & & 58 & $07 / 12 / 1915$ & Fazenda \\
\hline \multirow[t]{4}{*}{ Machado de Assis (1839 - 1908) } & \multirow[t]{4}{*}{ Brasil } & Historias sem data & 33 & $03 / 06 / 1915$ & Fazenda \\
\hline & & $\begin{array}{l}\text { Memorias póstumas } \\
\text { de Brás Cubas }\end{array}$ & 37 & $30 / 06 / 1915$ & Santos \\
\hline & & & 50 & $30 / 09 / 1915$ & Fazenda \\
\hline & & & 56 & $23 / 10 / 1915$ & Fazenda \\
\hline Mark Twain (1835 - 1910) & $\begin{array}{l}\text { Estados } \\
\text { Unidos }\end{array}$ & & 44 & $01 / 08 / 1915$ & S. Paulo \\
\hline Molière (1622-1673) & França & & 45 & $04 / 08 / 1915$ & S. Paulo \\
\hline Musset (1810-1857) & França & & 47 & $04 / 08 / 1915$ & S. Paulo \\
\hline \multirow[t]{3}{*}{ Nietzsche (1844 - 1900) } & \multirow[t]{3}{*}{ Alemanha } & & 11 & $23 / 01 / 1915$ & Fazenda \\
\hline & & & 35 & $30 / 06 / 1915$ & Santos \\
\hline & & Assim falou Zaratustra & 58 & $07 / 12 / 1915$ & Fazenda \\
\hline
\end{tabular}




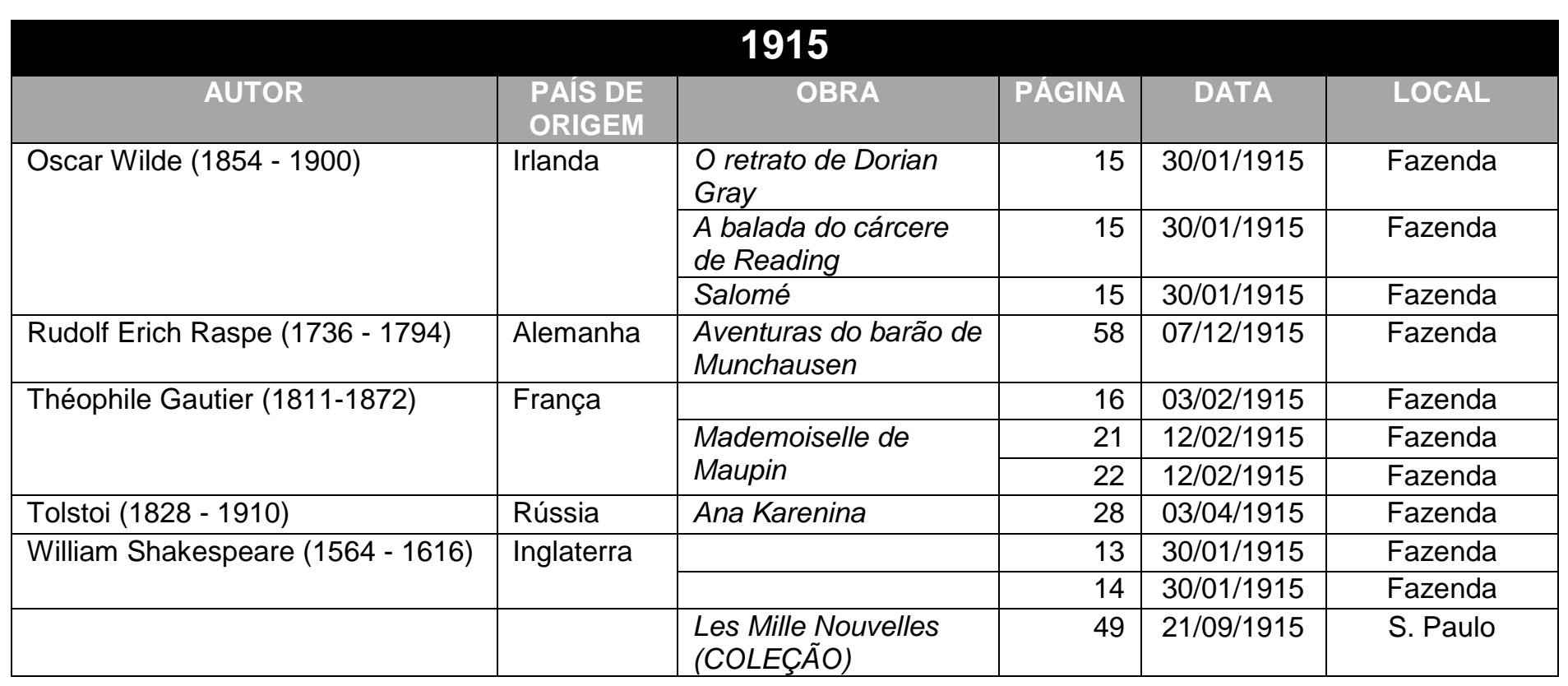

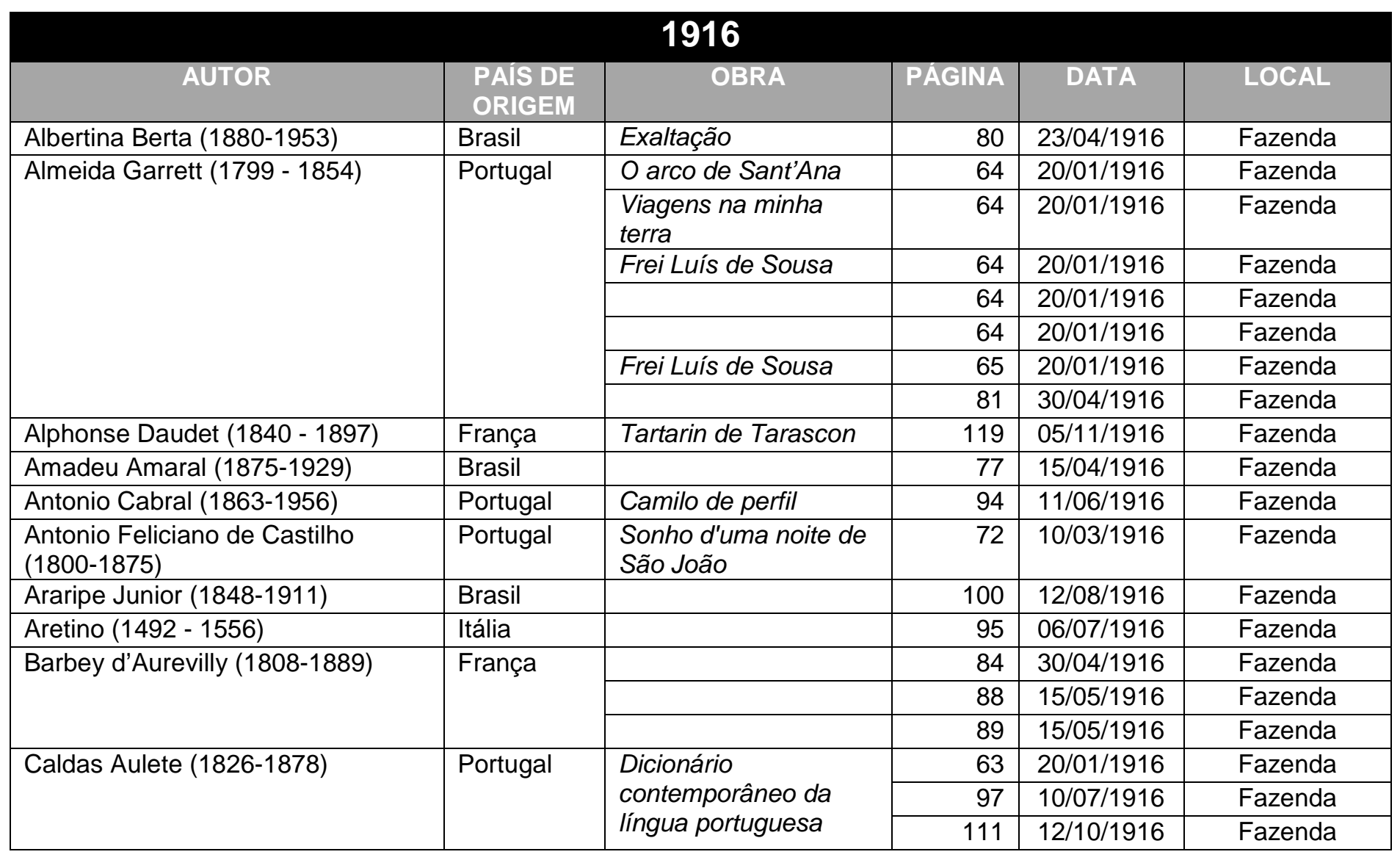




\begin{tabular}{|c|c|c|c|c|c|}
\hline \multicolumn{6}{|c|}{1916} \\
\hline AUTOR & $\begin{array}{l}\text { PAIS DE } \\
\text { ORIGEM }\end{array}$ & OBRA & PÁGINA & DATA & LOCAL \\
\hline \multirow{17}{*}{$\begin{array}{l}\text { Camilo Castelo Branco (1825 - } \\
\text { 1890) }\end{array}$} & \multirow[t]{17}{*}{ Portugal } & & 64 & $20 / 01 / 1916$ & Fazenda \\
\hline & & \multirow{3}{*}{$\begin{array}{l}\text { Onde está a } \\
\text { felicidade? }\end{array}$} & 65 & $20 / 01 / 1916$ & Fazenda \\
\hline & & & 66 & $20 / 01 / 1916$ & Fazenda \\
\hline & & & 68 & $07 / 02 / 1916$ & Fazenda \\
\hline & & Vinte horas de liteira & 69 & $07 / 02 / 1916$ & Fazenda \\
\hline & & & 81 & $30 / 04 / 1916$ & Fazenda \\
\hline & & & 88 & $15 / 05 / 1916$ & Fazenda \\
\hline & & & 89 & $15 / 05 / 1916$ & Fazenda \\
\hline & & Anos de prosa & 91 & $07 / 06 / 1916$ & Fazenda \\
\hline & & $\begin{array}{l}\text { Os brilhantes do } \\
\text { brasileiro }\end{array}$ & 91 & $07 / 06 / 1916$ & Fazenda \\
\hline & & Vingança & 94 & $11 / 06 / 1916$ & Fazenda \\
\hline & & & 98 & $10 / 07 / 1916$ & Fazenda \\
\hline & & Maria Moisés & 98 & $10 / 07 / 1916$ & Fazenda \\
\hline & & & 99 & $10 / 07 / 1916$ & Fazenda \\
\hline & & & 106 & $13 / 09 / 1916$ & Fazenda \\
\hline & & A brasileira de prazins & 110 & $08 / 10 / 1916$ & Fazenda \\
\hline & & & 111 & $08 / 10 / 1916$ & Fazenda \\
\hline \multirow[t]{2}{*}{ Carolina Michaelis (1851-1925) } & \multirow[t]{2}{*}{ Alemanha } & A saudade portuguesa & 78 & $15 / 04 / 1916$ & Fazenda \\
\hline & & & 79 & $15 / 04 / 1916$ & Fazenda \\
\hline D'Annunzio (1863 - 1938) & Itália & & 80 & $23 / 04 / 1916$ & Fazenda \\
\hline \multirow[t]{2}{*}{ Eça de Queirós (1845 - 1900) } & \multirow[t]{2}{*}{ Portugal } & Os maias & 98 & $10 / 07 / 1916$ & Fazenda \\
\hline & & & 110 & $08 / 10 / 1916$ & Fazenda \\
\hline Edmundo d'Amicis (1846-1908) & Itália & Cuore & 105 & $08 / 09 / 1916$ & Fazenda \\
\hline Esopo & & & 104 & 08/09/1916 & Fazenda \\
\hline Euclides da Cunha (1866 - 1909) & Brasil & & 79 & $15 / 04 / 1916$ & Fazenda \\
\hline \multirow[t]{2}{*}{ Giacomo Casanova (1725-1798) } & \multirow[t]{2}{*}{ Itália } & História da minha vida & 87 & $15 / 05 / 1916$ & Fazenda \\
\hline & & & 95 & $06 / 07 / 1916$ & Fazenda \\
\hline \multirow{5}{*}{$\begin{array}{l}\text { Godofredo de Moura Rangel (1884- } \\
\text { 1951) }\end{array}$} & \multirow[t]{5}{*}{ Brasil } & \multirow[t]{5}{*}{ Vida ociosa } & 80 & $23 / 04 / 1916$ & Fazenda \\
\hline & & & 82 & $30 / 04 / 1916$ & Fazenda \\
\hline & & & 87 & $15 / 05 / 1916$ & Fazenda \\
\hline & & & 101 & $30 / 08 / 1916$ & Fazenda \\
\hline & & & 102 & $30 / 08 / 1916$ & Fazenda \\
\hline \multirow[t]{3}{*}{ Goethe (1749 - 1832) } & \multirow[t]{3}{*}{ Alemanha } & Fausto & 72 & $10 / 03 / 1916$ & Fazenda \\
\hline & & $\begin{array}{l}\text { Fausto (Tradução de } \\
\text { Castilho para o } \\
\text { português) }\end{array}$ & 72 & $10 / 03 / 1916$ & Fazenda \\
\hline & & $\begin{array}{l}\text { Fausto (Tradução de } \\
\text { Gerard de Nerval para } \\
\text { o francês) }\end{array}$ & 72 & $10 / 03 / 1916$ & Fazenda \\
\hline Guilherme de Almeida (1890-1969) & Brasil & & 107 & 13/09/1916 & Fazenda \\
\hline Gustave Flaubert (1821 - 1880) & França & & 98 & 10/07/1916 & Fazenda \\
\hline Hippolyte Taine (1828 - 1893) & França & & 100 & $12 / 08 / 1916$ & Fazenda \\
\hline Homero (aprox. no século VIII a.C) & Grécia & Ilíada & 75 & $17 / 03 / 1916$ & Fazenda \\
\hline John Cleland (1709-1789) & Inglaterra & & 95 & $06 / 07 / 1916$ & Fazenda \\
\hline \multirow[t]{4}{*}{ José Antonio Nogueira } & \multirow[t]{4}{*}{ Brasil } & \multirow[t]{4}{*}{ Amor imortal } & 74 & $17 / 03 / 1916$ & Fazenda \\
\hline & & & 96 & $10 / 07 / 1916$ & Fazenda \\
\hline & & & 97 & $10 / 07 / 1916$ & Fazenda \\
\hline & & & 108 & $01 / 10 / 1916$ & S. Paulo \\
\hline
\end{tabular}




\begin{tabular}{|c|c|c|c|c|c|}
\hline & & 1916 & & & \\
\hline AUTOR & $\begin{array}{l}\text { PAIS DE } \\
\text { ORIGEM }\end{array}$ & OBRA & PÁGINA & DATA & LOCAL \\
\hline José de Alencar (1829 - 1877) & Brasil & As minas de prata & 75 & $17 / 03 / 1916$ & Fazenda \\
\hline & & O Guarani & 75 & $17 / 03 / 1916$ & Fazenda \\
\hline José Verissimo (1857-1916) & Brasil & & 109 & $01 / 10 / 1916$ & S. Paulo \\
\hline Kipling (1865 - 1936) & $\begin{array}{l}\text { Índia } \\
\text { (Bombaim, } \\
\text { colônia } \\
\text { britânica) }\end{array}$ & & 75 & $17 / 03 / 1916$ & Fazenda \\
\hline La Fontaine (1621-1695) & França & & 104 & $08 / 09 / 1916$ & Fazenda \\
\hline Lima Barreto (1881-1922) & Brasil & Triste fim de Policarpo & 100 & $12 / 08 / 1916$ & Fazenda \\
\hline & & Quaresma & 108 & $01 / 10 / 1916$ & S. Paulo \\
\hline Luiz Pereira Barreto (1840-1923) & Brasil & & 67 & $07 / 02 / 1916$ & Fazenda \\
\hline Machado de Assis (1839-1908) & Brasil & & 79 & $15 / 04 / 1916$ & Fazenda \\
\hline & & & 98 & $10 / 07 / 1916$ & Fazenda \\
\hline & & & 111 & $08 / 10 / 1916$ & Fazenda \\
\hline Manuel Bernardes (1644-1710) & Portugal & $\begin{array}{l}\text { Nova floresta ou silva } \\
\text { de vários apotegmas }\end{array}$ & 106 & $13 / 09 / 1916$ & Fazenda \\
\hline $\begin{array}{l}\text { Manuel de Oliveira Paiva (1861- } \\
\text { 1892) }\end{array}$ & Brasil & D. Guidinha do poço & 87 & $04 / 05 / 1916$ & Fazenda \\
\hline Marquês de Sade $(1740-1814)$ & França & & 95 & $06 / 07 / 1916$ & Fazenda \\
\hline Miguel de Cervantes (1547-1616) & Espanha & Dom Quixote & 74 & $17 / 03 / 1916$ & Fazenda \\
\hline Mirabeau (1749-1791) & França & & 95 & $06 / 07 / 1916$ & Fazenda \\
\hline Olavo Bilac (1865 - 1918) & Brasil & & 78 & $15 / 04 / 1916$ & Fazenda \\
\hline & & & 91 & $07 / 06 / 1916$ & Fazenda \\
\hline Osorio Estrada & Brasil & & 109 & $01 / 10 / 1916$ & S. Paulo \\
\hline Oswald de Andrade (1890-1954) & Brasil & & 107 & $13 / 09 / 1916$ & Fazenda \\
\hline Ruy Barbosa (1849 - 1923) & Brasil & & 79 & $15 / 04 / 1916$ & Fazenda \\
\hline & & & 82 & $30 / 04 / 1916$ & Fazenda \\
\hline Teixeira Pascoais (1877-1952) & Portugal & & 113 & $12 / 10 / 1916$ & Fazenda \\
\hline Théophile Gautier (1811-1872) & França & $\begin{array}{l}\text { Mademoiselle de } \\
\text { Maupin }\end{array}$ & 91 & $07 / 06 / 1916$ & Fazenda \\
\hline & & Fortunio & 91 & $07 / 06 / 1916$ & Fazenda \\
\hline & & Le capitain fracasse & 91 & $07 / 06 / 1916$ & Fazenda \\
\hline Veiga Miranda & Brasil & & 86 & $04 / 05 / 1916$ & Fazenda \\
\hline Vicente de Carvalho (1866-1924) & Brasil & & 77 & $15 / 04 / 1916$ & Fazenda \\
\hline Victor Hugo (1802 - 1885) & França & & 88 & $15 / 05 / 1916$ & Fazenda \\
\hline Walter Scott $(1771-1832)$ & Escócia & & 75 & $17 / 03 / 1916$ & Fazenda \\
\hline William Shakespeare (1564 - 1616) & Inglaterra & & 111 & $08 / 10 / 1916$ & Fazenda \\
\hline & & Larousse & 88 & $15 / 05 / 1916$ & Fazenda \\
\hline
\end{tabular}




\begin{tabular}{|c|c|c|c|c|c|}
\hline \multicolumn{6}{|c|}{$\begin{array}{ll}1917 & 1917\end{array}$} \\
\hline AUTOR & $\begin{array}{l}\text { PAIS DE } \\
\text { ORIGEM }\end{array}$ & OBRA & PÁGINA & DATA & LOCAL \\
\hline \multirow[t]{2}{*}{ Alberto Seabra } & & & 146 & $21 / 07 / 1917$ & Fazenda \\
\hline & & & 150 & 09/08/1917 & Fazenda \\
\hline Alexandre Dumas & França & & 127 & $10 / 01 / 1917$ & Fazenda \\
\hline Alexandre Herculano (1810 - 1877) & Portugal & & 156 & $11 / 10 / 1917$ & Caçapava \\
\hline $\begin{array}{l}\text { Almáchio Diniz Gonçalves (1880- } \\
\text { 1937) }\end{array}$ & Brasil & Bodas negras & 136 & $22 / 04 / 1917$ & Fazenda \\
\hline Anatole France (1844 - 1924) & França & Le lys rouge & 136 & $10 / 05 / 1917$ & Fazenda \\
\hline Antonio Vieira (1608-1697) & Portugal & & 156 & $11 / 10 / 1917$ & Caçapava \\
\hline Bernardo Guimarães (1825 - 1884) & Brasil & & 162 & $11 / 12 / 1917$ & S. Paulo \\
\hline \multirow{18}{*}{$\begin{array}{l}\text { Camilo Castelo Branco (1825 - } \\
\text { 1890) }\end{array}$} & \multirow[t]{18}{*}{ Portugal } & & 136 & $22 / 04 / 1917$ & Fazenda \\
\hline & & Maria Moisés & 137 & $10 / 05 / 1917$ & Fazenda \\
\hline & & & 139 & $05 / 06 / 1917$ & Fazenda \\
\hline & & & 142 & $06 / 07 / 1917$ & Fazenda \\
\hline & & & 147 & $21 / 07 / 1917$ & Fazenda \\
\hline & & A Mulher fatal & 148 & $21 / 07 / 1917$ & Fazenda \\
\hline & & Noites de insônia & 149 & $21 / 07 / 1917$ & Fazenda \\
\hline & & & 153 & $30 / 10 / 1917$ & Caçapava \\
\hline & & & 155 & $30 / 10 / 1917$ & Caçapava \\
\hline & & Novelas do Minho & 155 & $30 / 10 / 1917$ & Caçapava \\
\hline & & Maria Moisés & 155 & $30 / 10 / 1917$ & Caçapava \\
\hline & & & 156 & $11 / 10 / 1917$ & Caçapava \\
\hline & & O vinho do Porto & 159 & $04 / 11 / 1917$ & S. Paulo \\
\hline & & & 161 & $11 / 12 / 1917$ & S. Paulo \\
\hline & & & 162 & $11 / 12 / 1917$ & S. Paulo \\
\hline & & & 168 & $28 / 12 / 1917$ & S. Paulo \\
\hline & & & 168 & $28 / 12 / 1917$ & S. Paulo \\
\hline & & & 169 & $28 / 12 / 1917$ & S. Paulo \\
\hline Catulle Mendès (1831-1897) & França & & 162 & $11 / 12 / 1917$ & S. Paulo \\
\hline Charles Dickens (1812 - 1870) & Inglaterra & $\begin{array}{l}\text { As aventuras do Sr. } \\
\text { Pickwick }\end{array}$ & 139 & $05 / 06 / 1917$ & Fazenda \\
\hline Coelho Neto (1864 - 1934) & Brasil & & 162 & $11 / 12 / 1917$ & S. Paulo \\
\hline \multirow[t]{2}{*}{ Dr. Bruckner } & & \multirow{2}{*}{$\begin{array}{l}\text { O médico homeopata } \\
\text { da família }\end{array}$} & 132 & $03 / 03 / 1917$ & Fazenda \\
\hline & & & 133 & $03 / 03 / 1917$ & Fazenda \\
\hline Eça de Queirós (1845 - 1900) & Portugal & $\begin{array}{l}\text { A ilustre casa de } \\
\text { Ramires }\end{array}$ & 153 & $30 / 10 / 1917$ & Caçapava \\
\hline Émile Zola (1840 - 1902) & França & & 154 & $30 / 10 / 1917$ & Caçapava \\
\hline Euclides da Cunha (1866 - 1909) & Brasil & & 162 & $11 / 12 / 1917$ & S. Paulo \\
\hline \multirow[t]{4}{*}{ Fialho d'Almeida (1857 - 1911) } & \multirow[t]{4}{*}{ Portugal } & & 153 & $30 / 10 / 1917$ & Caçapava \\
\hline & & & 154 & $30 / 10 / 1917$ & Caçapava \\
\hline & & & 155 & $30 / 10 / 1917$ & Caçapava \\
\hline & & & 163 & $11 / 12 / 1917$ & S. Paulo \\
\hline Giovanni Boccacio (1313-1375) & França & & 137 & 10/05/1917 & Fazenda \\
\hline
\end{tabular}




\begin{tabular}{|c|c|c|c|c|c|}
\hline \multicolumn{6}{|c|}{$\begin{array}{ll}1917 & 19\end{array}$} \\
\hline AUTOR & $\begin{array}{l}\text { PAIS DE } \\
\text { ORIGEM }\end{array}$ & OBRA & PÁGINA & DATA & LOCAL \\
\hline \multirow{11}{*}{$\begin{array}{l}\text { Godofredo de Moura Rangel (1884- } \\
\text { 1951) }\end{array}$} & \multirow[t]{11}{*}{ Brasil } & \multirow[t]{7}{*}{ Vida ociosa } & 137 & $10 / 05 / 1917$ & Fazenda \\
\hline & & & 138 & $10 / 05 / 1917$ & Fazenda \\
\hline & & & 139 & $05 / 06 / 1917$ & Fazenda \\
\hline & & & 142 & $06 / 07 / 1917$ & Fazenda \\
\hline & & & 143 & $08 / 07 / 1917$ & Fazenda \\
\hline & & & 147 & $21 / 07 / 1917$ & Fazenda \\
\hline & & & 149 & $03 / 08 / 1917$ & Fazenda \\
\hline & & \multirow[t]{3}{*}{ Falange gloriosa } & 151 & $24 / 09 / 1917$ & Caçapava \\
\hline & & & 158 & $11 / 10 / 1917$ & Caçapava \\
\hline & & & 165 & $11 / 12 / 1917$ & S. Paulo \\
\hline & & Vida ociosa & 165 & $11 / 12 / 1917$ & S. Paulo \\
\hline Gorki (1868 - 1936) & Rússia & & 162 & $11 / 12 / 1917$ & S. Paulo \\
\hline \multirow[t]{2}{*}{ Guilherme de Almeida (1890-1969) } & \multirow[t]{2}{*}{ Brasil } & Nós & 144 & $08 / 07 / 1917$ & Fazenda \\
\hline & & & 145 & $08 / 07 / 1917$ & Fazenda \\
\hline Gustave Flaubert (1821 - 1880) & França & Salambô & 148 & $21 / 07 / 1917$ & Fazenda \\
\hline Guy de Maupassant $(1850-1893)$ & França & Une Vie & 136 & $22 / 04 / 1917$ & Fazenda \\
\hline Henry Louis Mencken & $\begin{array}{l}\text { Estados } \\
\text { Unidos }\end{array}$ & & 162 & $11 / 12 / 1917$ & S. Paulo \\
\hline \multirow[t]{2}{*}{ Hippolyte Taine (1828 - 1893) } & \multirow[t]{2}{*}{ França } & \multirow[t]{2}{*}{ Correspondência } & 163 & $11 / 12 / 1917$ & S. Paulo \\
\hline & & & 164 & $11 / 12 / 1917$ & S. Paulo \\
\hline $\begin{array}{l}\text { Joaquim Manuel de Macedo (1820- } \\
\text { 1882) }\end{array}$ & Brasil & & 162 & $11 / 12 / 1917$ & S. Paulo \\
\hline José de Alencar $(1829-1877)$ & Brasil & & 162 & $11 / 12 / 1917$ & S. Paulo \\
\hline Julio Verne (1828 - 1905) & França & & 166 & $28 / 12 / 1917$ & S. Paulo \\
\hline Kipling (1865 - 1936) & $\begin{array}{l}\text { Índia } \\
\text { (Bombaim, } \\
\text { colônia } \\
\text { britânica) }\end{array}$ & & 162 & $11 / 12 / 1917$ & S. Paulo \\
\hline $\begin{array}{l}\text { Luís Vaz de Camões (cerca de } \\
1525-1580 \text { ) }\end{array}$ & Portugal & Os lusíadas & 141 & $05 / 06 / 1917$ & Fazenda \\
\hline \multirow[t]{3}{*}{ Machado de Assis (1839 - 1908) } & \multirow[t]{3}{*}{ Brasil } & & 149 & $03 / 08 / 1917$ & Fazenda \\
\hline & & & 162 & $11 / 12 / 1917$ & S. Paulo \\
\hline & & & 168 & $28 / 12 / 1917$ & S. Paulo \\
\hline Mark Twain (1835 - 1910) & $\begin{array}{l}\text { Estados } \\
\text { Unidos }\end{array}$ & & 159 & $04 / 11 / 1917$ & S. Paulo \\
\hline \multirow[t]{3}{*}{ Menotti del Picchia (1892-1988) } & \multirow[t]{3}{*}{ Brasil } & Moisés & 135 & $22 / 04 / 1917$ & Fazenda \\
\hline & & & 140 & $05 / 06 / 1917$ & Fazenda \\
\hline & & & 145 & $08 / 07 / 1917$ & Fazenda \\
\hline \multirow[t]{2}{*}{ Nietzsche (1844 - 1900) } & \multirow[t]{2}{*}{ Alemanha } & & 155 & $30 / 10 / 1917$ & Caçapava \\
\hline & & & 156 & $11 / 10 / 1917$ & Caçapava \\
\hline \multirow[t]{2}{*}{ Olavo Bilac (1865 - 1918) } & \multirow[t]{2}{*}{ Brasil } & & 140 & $05 / 06 / 1917$ & Fazenda \\
\hline & & & 144 & $08 / 07 / 1917$ & Fazenda \\
\hline Paul Koch (1794-1871) & França & & 127 & $10 / 01 / 1917$ & Fazenda \\
\hline Pierre Loti $(1850-1923)$ & França & & 162 & $11 / 12 / 1917$ & S. Paulo \\
\hline Raul Pompéia (1863 - 1895) & Brasil & O ateneu & 158 & $11 / 10 / 1917$ & Caçapava \\
\hline \multirow[t]{5}{*}{ Ruy Barbosa (1849 - 1923) } & \multirow[t]{5}{*}{ Brasil } & & 155 & $11 / 10 / 1917$ & Caçapava \\
\hline & & & 156 & $11 / 10 / 1917$ & Caçapava \\
\hline & & & 157 & $11 / 10 / 1917$ & Caçapava \\
\hline & & & 162 & $11 / 12 / 1917$ & S. Paulo \\
\hline & & & 165 & $11 / 12 / 1917$ & S. Paulo \\
\hline
\end{tabular}




\begin{tabular}{|c|c|c|c|c|c|}
\hline AUTOR & $\begin{array}{l}\text { PAIS DE } \\
\text { ORIGEM }\end{array}$ & OBRA & PÁGINA & DATA & LOCAL \\
\hline Sevène & & Gramática francesa & 127 & 10/01/1917 & Fazenda \\
\hline Stendhal (1783 - 1842) & França & & 166 & $28 / 12 / 1917$ & S. Paulo \\
\hline \multirow{3}{*}{$\begin{array}{l}\text { Thomas Babington Macaulay (1800 } \\
\text { - 1859) }\end{array}$} & \multirow[t]{3}{*}{ Inglaterra } & & 139 & $05 / 06 / 1917$ & Fazenda \\
\hline & & The history of England & 163 & $11 / 12 / 1917$ & S. Paulo \\
\hline & & $\begin{array}{l}\text { Critical and historical } \\
\text { essays }\end{array}$ & 164 & $11 / 12 / 1917$ & S. Paulo \\
\hline Tolstoi $(1828-1910)$ & Rússia & & 140 & $05 / 06 / 1917$ & Fazenda \\
\hline Veiga Miranda & Brasil & Ressurreição & 145 & $08 / 07 / 1917$ & Fazenda \\
\hline Vicente de Carvalho (1866-1924) & Brasil & & 145 & $08 / 07 / 1917$ & Fazenda \\
\hline \multirow[t]{2}{*}{ William Shakespeare (1564 - 1616) } & \multirow[t]{2}{*}{ Inglaterra } & & 156 & $11 / 10 / 1917$ & Caçapava \\
\hline & & & 158 & $04 / 11 / 1917$ & S. Paulo \\
\hline
\end{tabular}




\title{
Complemento B - Carta de Georgette Tavares Bastos à Editora Brasiliense Ltda. ${ }^{2}$
}

\author{
Bi. $-m 500085$ \\ Parts, em 31 de dezembro de 2059.
}

Ed1 tors Brasiliense Itcia.

Rua Barto de Itrapotinlinga, 93

Săo ?uila

Prezados Bethores,
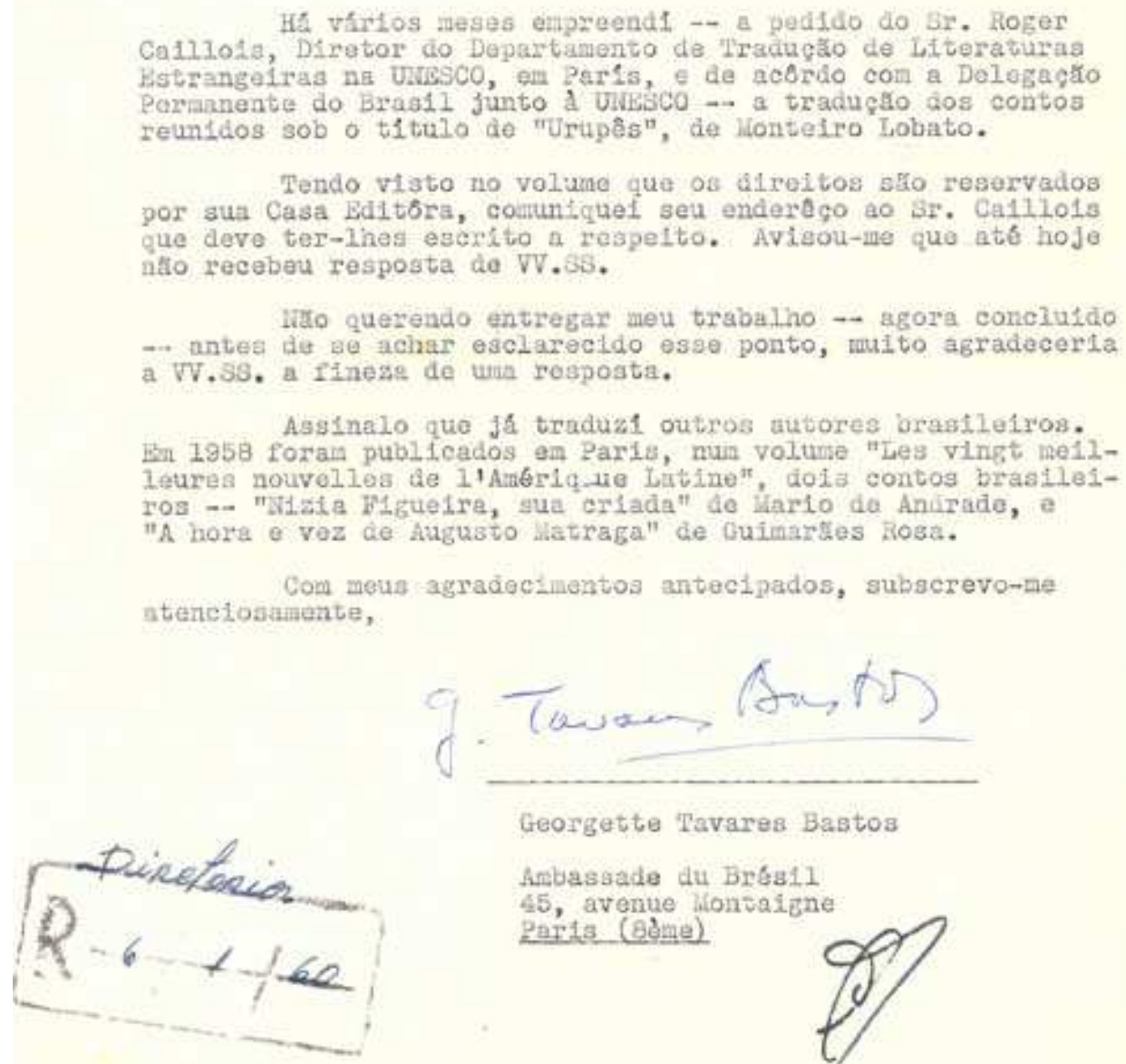

Georgette Tavares Bastos

Artbassade du Brés11 45, avenue Konvaigne paris (Beme)

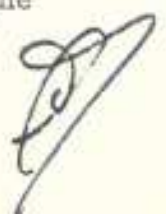

2 Disponível em: http://www.unicamp.br/iel/monteirolobato/corre_ter/BL_ms00085.htm Acesso em: 04 abr 2013. 


\section{TRANSCRIÇÃO}

Paris, em 31 de dezembro de 1959.

Editora Brasiliense Ltda.

Rua Barão de Itapetininga, 93

São Paulo

Prezados Senhores,

Há vários meses empreendi - a pedido do Sr. Roger Caillois, Diretor do Departamento de Tradução de Literaturas Estrangeiras na UNESCO, em Paris, e de acordo com a Delegação Permanente do Brasil junto à UNESCO - a tradução dos contos reunidos sob o título de "Urupês", de Monteiro Lobato.

Tendo visto no volume que os direitos são reservados por sua Casa Editora, comuniquei seu endereço ao Sr. Caillois que deve ter-lhes escrito a respeito. Avisou-me que até hoje não recebeu resposta de VV.SS.

Não querendo entregar meu trabalho - agora concluído - antes de se achar esclarecido esse ponto, muito agradeceria a VV.SS. a fineza de uma resposta.

Assinalo que já traduzi outros autores brasileiros. Em 1958 foram publicados em Paris, num volume "Les vingt meilleures nouvelles de l'Amérique Latine", dois contos brasileiros "Nízia Figueira, sua criada" de Mário de Andrade, e "A hora e a vez de Augusto Matraga" de Guimarães Rosa.

Com meus agradecimentos antecipados, subscrevo-me atenciosamente.

[Assinatura à tinta de Georgette Tavares Bastos]

Georgette Tavares Bastos

Diretorior

[carimbo] R $6 \begin{array}{lll}6 & 1 & / 60\end{array}$

Ambassade du Brésil 45, avenue Montaigne Paris (8ème)

[Assinatura à tinta] 


\section{Complemento C - Carta de Georgette Tavares Bastos à Ruth Monteiro Lobato $^{3}$}

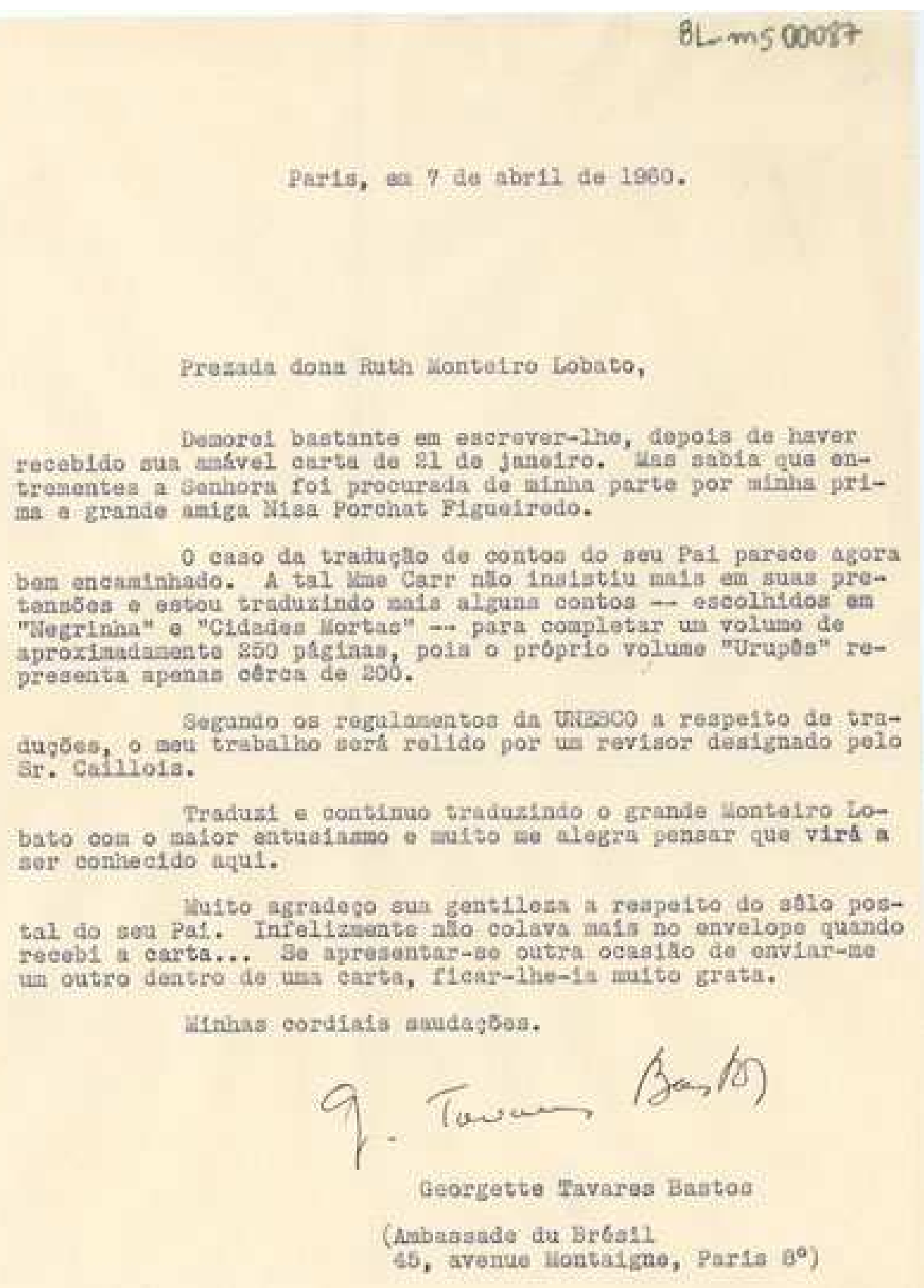

3 Disponível em: http://www.unicamp.br/iel/monteirolobato/corre_ter/BL_ms00087.htm Acesso em: 04 abr 2013. 


\section{TRANSCRIÇÃO}

Paris, em 7 de abril de 1960.

Prezada dona Ruth Monteiro Lobato,

Demorei bastante em escrever-lhe, depois de haver recebido sua amável carta de 21 de janeiro. Mas sabia que entrementes a Senhora foi procurada de minha parte por minha prima e grande amiga Nisa Porchat Figueiredo.

O caso da tradução de contos do seu Pai parece agora bem encaminhado. A tal Mme. Carr não insistiu mais em suas pretensões e estou traduzindo mais alguns contos escolhidos em Negrinha e Cidades Mortas - para completar um volume de aproximadamente 250 páginas, pois o próprio volume Urupês representa apenas cerca de 200.

Segundo os regulamentos da UNESCO a respeito de traduções, o meu trabalho será relido por um revisor designado pelo Sr. Caillois.

Traduzi e continuo traduzindo o grande Monteiro Lobato com o maior entusiasmo e muito me alegra pensar que virá a ser conhecido aqui.

Muito agradeço sua gentiliza a respeito do selo postal do seu Pai. Infelizmente não colava mais no envelope quando recebi a carta... Se apresentar-se outra ocasião de enviar-me um outro dentro de uma carta, ficar-lhe-ia muito grata.

Minhas cordiais saudações.

[Assinatura à tinta de Georgette Tavares Bastos]

Georgette Tavares Bastos

(Ambassade du Brésil

45, avenue Montaigne, Paris $8^{\circ}$ ) 


\section{Complemento D - Texto de Monteiro Lobato}

\section{Curioso caso de materializaçãa ${ }^{4}$}

A sobrevivência espiritual é um fato. Os intermúndios andam povoados de sombras, ou larvas, ou almas, que às vezes se dão ao luxo duma temporária reencarnação. Agora pelo carnaval tive prova disso.

Deambulava eu a desoras por uma praça vazia, pintalgada de confete, com estilhas micantes de lança-perfumes nos passeios e fitas serpentinas a balouçarem-se das árvores, quando divisei na minha frente uma sombra a medir passos, meditativa. Botas à Frederica, chapéu de canudo à 1870, sobrecasaca de cintura - um homem, evidentemente fantasiado de Camilo Castelo Branco, como o pintam as capas vermelhas da edição Chardron. A tantas, o figurão apanhou da poeira um pedaço de papel, que examinou com atenção à luz do gás. Cruzei-me com ele, cortejei-o. A sombra retribuiu a saudação e interpelou-me:

- Moço, está certo de que esta terra é uma que Álvares Cabral descobriu, a contragosto, séculos atrás?

Encarei-o a fito: era Camilo em pessoa - a bigodeira, as maças salientes, o ar escaveirado... Estremeci e balbuciei:

- É, mestre, isto é o Brasil ainda com $s$ ou $z$ à vontade.

- Inda reina Pedro Segundo, o neto de Marco Aurélio?

- Onde vai isso! É morto o grande velho; baniram-no pelo crime de ser bom, justo e sábio. Ocupa seu lugar um bando de "maiores brasileiros vivos" que, a falar a verdade, somados e multiplicados uns pelos outros, não valem o sabugo da unha do mata-piolho do velho.

- E que língua se fala por aqui?

- A portuguesa, está claro.

\footnotetext{
${ }^{4}$ LOBATO, Monteiro. "Curioso caso de materialização". In: Ideias de Jeca Tatu. São Paulo: Globo, 2008, p.130-35.
} 
- Não me parece, objetou a sombra, sacando das algibeiras o papelucho apanhado na rua. Conheço-me em vernáculo, chamaram-me mestre durante a vida terrena. Ora, sucede que neste periódico vejo um anúncio em língua que não é a minha, nem é língua viva ou morta de meu conhecimento. Será o idioma do futuro? É nesta sopa juliana que os da terra se entendem?

Corri os olhos sobre o papel, e corei: o anúncio estava redigido no dialeto dos elegantes.

\section{TRIANON}

Estabelecimento para gozo das exmas. famílias

DINERS CHICS A PRIX FIXE

Мепu

CONSOMMÉ AUX REJETONS

RIZ AU FOUR À LA KIRIAL

SUPRÊME DE TURBOT

COEUR DE MACASSIN

CRÊME PRINCESSE

ETC.

FIVE-Ó-CLOC-TEA

Aos domingos diners concerts chics a prix fixe com menus delicados.

- Tem razão, mestre. Isto é um produto da podridão do chique.

- Que?

- Diz-se cá destes vórtices de elegância: "podre de chique!"

Camilo olhou-me comiserado; depois, baixando os olhos para o papel, comentou. 
- Já o nome desta baiuca me não soa bem. Batizar uma casa de pasto, cá na América, com o nome dum antigo castelo francês, sabe-me a disparate. Que é que lá se faz?

- Come-se, bebe-se, dança-se...

- O nome, então, deveria ser "À Comedoria Paulistana”, ou “Aos bebes da Avenida”, ou “À grossa pagodeira”, coisa assim toando com as funções do negócio. Mas vá lá. Quer o Candido de Figueiredo que nome cada um pinte o seu como lhe apraz. Noto, entretanto, este adendo explicativo: estabelecimento para gozo das exmas. famílias. Estabelecimento para gozo! Que parvoiçada é esta, moço?

- O mestre a definiu: uma parvoiçada.

- E este - Five-ó-cloc-tea? Cheira-me a inglês, mas não é inglês, salvo se da Bosquimania. O clock no meu tempo trazia um " $\mathrm{k}$ " final, muito gracioso como enfeite coccigeano da palavra. Comeram-no, por quê? São kafagos os teus coetâneos, moço? Adiante: Aos domingos diners concerts chics a prix fixe com menus delicados. Que soberba nabiça! Na Somália nenhum soba letrado comporia melhor salada de batatas. Como não há no período palavras grifadas, suponho que o que me parece francês são vocábulos já naturalizados no país. Acho razoável que a língua adote termos exóticos quando os não possue correspondentes. Mas neste caso diners diz mais que jantar? Prix-fixe é coisa diferente de preço fixo? Menu vai além da carta ou do cardápio? Que motivos levam vocês a pintalgarem a língua destas excrescências inúteis?

- A elegância, mestre.

- E que coisa é a elegância?

- É isto, mestre: uma sensação, uma sugestão. Quando dizemos: a senhora Fulana, sentimo-nos chinfrins; mas si dizemos: Madame Tal, oh gozo d'alma! Um bafo de parisianismo nos brumeliza por dentro e por fora. Incapazes de realizar a verdadeira elegância, que é um modo de ser e fazer desembaraçado, fácil, sem constrangimento nem excesso - uma justa medida no movimento e na atitude - nós inventamos esta maquilhagem do gosto, da palavra, dos sentimentos. E impamos, admirando-nos uns aos outros com ares parvajolas. 
- No meu tempo chamava-se isto macaquice. Vejo que ela progride, pois não!... disse Camilo - e, voltando ao tema, continuou:

- Leio cá, diners chics. Outrora, quando um jantar era um jantar, se lhe apensavam um qualificativo este só dizia respeito ao seu valor culinário ou nutriente - jantar suculento, jantar opíparo, jantar à moda velha. Mas este "jantar chic" sabe-me a "laranja sutil”, a "pão elegante", a "ananás janota", a "feijoada distinta de maneiras", a "batata grácil" e quejandas asnidades.

- É a elegância, mestre, é o requinte!

- Espanta-me também o que os elegantes comem. Crême Princesse. Que coisa é?

- Uma gemada qualquer, mestre, a excelência do prato está no nome.

- Suprême de turbot...

- Isso é uma papa de cação de Santos.

- Coeur de ma... quê? ma-cas-sin... Macassin! Salta rumor! Em França chamam aos bacorinhos, ou leitões, marcassins. Aqui os kafagos são também refagos. Comem, além do coração do porquinho, o "r" do marcassin! Porque não dizem às claras - leitão?

- Ah, mestre, que ingenuidade a vossa!

- E este riz au four? É arroz de forno, evidentemente. Mas, amigo, se o que vocês comem é o porco e o arroz e se o fato de dar o nome de marcassin ao porco, e riz ao arroz e four ao forno, não melhora o sabor do quitute, por que esta parva mentira da desnaturalização dos pitéus?

- Ah mestre! Como estamos longe do vosso bom senso! A cultura refinou-nos. A civilização cresce em Vila Mariana como a mamona. Adquirimos tanto gout que, por instinto, o nosso organismo, num diner elegante, repeliria com vomissements incoercibles um plat nomeado à portuguesa, charramente: arroz de forno, leitão assado. É mister que eles venham, embora não mudados de substância, transfeitos em marcassin, ou riz au four à la princesse Quelque Chose. Só assim as fibras da estesia gustativa nos tremelicam de gozo e dos olhos nos correm lágrimas a Brillat Sarvarin. 
- Mas o povo desta terra não espinoteia de riso diante da macaqueira?

- O povo abre a boca. Mas que importa o povo? Valem as elites, e para estas é prova de suprema distinção receber lições de elegância do Vatel que organiza a macaqueira e dos garçons que a dirigem. No diners, é de bom tom falar nessa língua burundanga e mastigar com religiosa unção todos os marcassins apresentados, fingindo não saber que aquilo nasceu e cresceu num chiqueiro. Os gestos, o modo de pegar no garfo, os movimentos das maxilas são, no elegante, pautados por um código de que os garçons são os fiscais. O grande castigo é incorrer num sorriso comiserado do garçom. Dum elegante contam que, certa vez, inadvertidamente, comeu o peixe com a faca, e como, caído em si, vislumbrasse um sorriso irônico na cara lavada do garçom, ali mesmo deu cabo da vida a tiros de revolver. Não pôde sobreviver à desonra, o desgraçado!

- Estes garçons tão poderosos serão acaso plenipotenciários do Instituto de França, ou coisa que o valha, aqui destacados em missão civilizatória?

- Nada disso, mestre. São uns pobres diabos que na terra natal foram lacaios e aprenderam, espiando da copa, os hábitos dos patrões. Postos no olho da rua, enfiaram-se num porão de navio e, aqui, com grande assombro deles próprios, viram-se transfeitos em mestres e árbitros do bom tom. Dão-nos a comer o que lhes convém e obrigam-nos a comer como lhes apraz.

- Os paulistanos, então, não comem o que querem?

- Oh, não! Comer o que se quer é regionalismo sórdido. Come-se o que é de bom tom comer. Manducar leitão assado, picadinho, feijoada, pamonha de milho verde, moqueca e outros petiscos da terra, é uma vergonha tão grande como pintar paisagens locais, romancear tragédias do meio, poetar sentimentos do povo. Até o uso desta língua que herdamos está em via de tornar-se ignominioso. Na altíssima roda já a repudiaram para uma idílica mancebia com o francês argelino. Que dirá o estrangeiro se nos pilhar a comer (que horror, meu Deus!) tutu com torresmo, esta vergonhosa pitança regional, ou coisas semelhantes?

E assim, na vida como nas artes, a vitória do dernier cri é completa. O estilo e a língua desse anúncio comentado atrás é o estilo vitorioso, o estilo de amanhã. Veja mestre, a que altitudes ascendemos!... 
Calei-me. Camilo sacudiu a cabeça como quem viu mais do que esperava. Depois disse:

- Sabe que mais? Vou desmaterializar-me já e já; volto aos intermúndios e lá darei à sombra de Cabral pêsames pela asneira que praticou. Receio que deem vocês de criar pelo no corpo e vos nasçam caudas no cóccix, e se ponham todos de repente a marinhar árvores acima com bananas na munheca - desmentindo Darwin. O inglês pôs o macaco no começo da evolução: vocês provam que ele acertaria melhor pondo-o no fim. Au revoir!

E lá zarpou para as estrelas a sombra do grande mestre... 
Complemento E - Tabela dos títulos publicados pela Revista do Brasil e pelas editoras Monteiro Lobato \& Cia., Cia. Graphico-Editora Monteiro Lobato e a Cia. Editora Nacional ${ }^{1}$

\begin{tabular}{|c|c|c|c|c|}
\hline & AUTOR & TÍTULO & GÊNERO & ASSUNTO \\
\hline 1. & A. de Almeida Junior & Cartilha de higiene & & Didática \\
\hline 2. & Abel Juruá & Uma aventura & Conto & Literatura Brasileira \\
\hline 3. & Abel Juruá & A veranista & Romance & Literatura Brasileira \\
\hline 4. & Abelardo Pompeu do Amaral & Cultura prática e racional do cafeeiro & & Agricultura \\
\hline 5. & Abilio Augusto de Noronha Silva & Narrando a verdade & & História \\
\hline 6. & Adalberto Garcia & Justiça em São Paulo & & Direito \\
\hline 7. & Aderbal Pinheiro Machado Tolosa & Contribuição ao estudo dos pneumococos & & Medicina \\
\hline 8. & Afonso Celso de Assis Figueiredo & Trovas de Espanha & Poema & Literatura Brasileira \\
\hline 9. & Afonso de Freitas & Tradições e reminiscências paulistanas & & História \\
\hline
\end{tabular}

\footnotetext{
${ }^{1}$ Tabela disponível em: GARCIA, Juliana Cristina. Monteiro Lobato: contista e editor. Dissertação de Mestrado (orientação: Alckmar Luiz dos Santos). Florianópolis, Santa Catarina: Universidade Federal de Santa Catarina, 2013.
} 


\begin{tabular}{|c|c|c|c|c|}
\hline & AUTOR & TÍTULO & GÊNERO & ASSUNTO \\
\hline 10. & Afonso Dionísio Gama & Alistamento eleitoral & & Direito \\
\hline 11. & Afonso Dionísio Gama & Código eleitoral do Estado de São Paulo & & Direito \\
\hline 12. & Afonso Dionísio Gama & Contas assinadas & & Direito \\
\hline 13. & Afonso Dionísio Gama & Organização judiciária do Estado de São Paulo & & Direito \\
\hline 14. & Afonso Dionísio Gama & $\begin{array}{l}\text { Código eleitoral da República ou consolidação, } \\
\text { anotada e explicada, de todas as disposiçôes legais, } \\
\text { atualmente em... }\end{array}$ & & Direito eleitoral \\
\hline 15. & Afonso Dionísio Gama & Tobias Barreto & Biografia & Literatura Brasileira \\
\hline 16. & Afonso Lopes de Almeida & Através da Europa & & História \\
\hline 17. & Afonso Schmidt & Os impunes & Conto & Literatura Brasileira \\
\hline 18. & $\begin{array}{l}\text { Afrânio Peixoto, Coelho Neto, Viriato Corrêa } \\
\text { e Medeiros Albuquerque }\end{array}$ & O mistério & Romance & Literatura Brasileira \\
\hline 19. & Agenor Silveira & Colocação de pronomes & & Filologia \\
\hline 20. & Alberto Conte & Reflexões & & Psicologia \\
\hline 21. & Alberto Seabra & $\begin{array}{l}\text { Higiene e tratado homeopático das moléstias } \\
\text { domésticas }\end{array}$ & & Medicina. Homeopatia \\
\hline 22. & Alberto Seabra & Problemas sul-americanos & & Política \\
\hline
\end{tabular}




\begin{tabular}{|c|c|c|c|c|}
\hline & AUTOR & TÍTULO & GÊNERO & ASSUNTO \\
\hline 23. & Alberto Seabra & A alma e o subconsciente & & Psicologia \\
\hline 24. & Alberto Seabra & Fenômenos psíquicos & & Psicologia \\
\hline 25. & Alberto Seabra & O problema do além e do destino & & Religião. Espiritismo. \\
\hline 26. & Alberto Seabra & Fenômenos psíquicos & & Psicologia \\
\hline 27. & Alcides Maia & Prismas & Ensaios, crítica, etc. & Literatura Brasileira \\
\hline 28. & Alduino Estrada & Estrada luminosa & & Didática \\
\hline 29. & Alexandre Dumas & A mão do finado & Romance & Literatura Estrangeira \\
\hline 30. & Alexandre Dumas & Dama de Monsoreau & Romance & Literatura Estrangeira \\
\hline 31. & Alexandre Dumas & $O$ conde de monte Cristo & Romance & Literatura Estrangeira \\
\hline 32. & Alexandre Dumas & O visconde de Bragelonne & Romance & Literatura Estrangeira \\
\hline 33. & Alexandre Dumas & Os três mosqueteiros & Romance & Literatura Estrangeira \\
\hline 34. & Alfredo d'Escragnolle Taunay & Visões do sertão & Ensaios, crítica, etc. & Geografia \\
\hline 35. & Alfredo d'Escragnolle Taunay & Dias de guerra e de sertão & Ensaios, crítica, etc. & História \\
\hline
\end{tabular}




\begin{tabular}{|c|c|c|c|c|}
\hline & AUTOR & TÍTULO & GÊENERO & ASSUNTO \\
\hline 36. & Alfredo d'Escragnolle Taunay & Inocência & Romance & Literatura Brasileira \\
\hline 37. & Alfredo d'Escragnolle Taunay & Ouro sobre azul & Romance & Literatura Brasileira \\
\hline 38. & Alfredo Romário Martins & Curitiba de outrora e de hoje. & & História \\
\hline 39. & Almaquio Diniz & Meus ódios e meus afetos & Ensaios, crítica, etc. & Literatura Brasileira \\
\hline 40. & Almaquio Diniz & Da falência & & Direito \\
\hline 41. & Almeida Nogueira & Economia política & Ensaios, crítica, etc & Economia \\
\hline 42. & Almeida Nogueira & Podem os municípios contrair empréstimos? & Ensaios, crítica, etc. & Direito \\
\hline 43. & Almeida Nogueira & Estudo sobre a denominação "econômica política" & Ensaios, crítica, etc. & Direito; Economia \\
\hline 44. & Almeida Nogueira & Estudos ligeiros & Ensaios, crítica, etc. & Literatura Brasileira \\
\hline 45. & Almeida Nogueira & Marcas de fábrica & & Direito \\
\hline 46. & Almeida Nogueira & Marcas industriais & & Direito \\
\hline 47. & Almeida Nogueira & $\begin{array}{l}\text { Marcas industriais e nome comercial no direito } \\
\text { brasileiro }\end{array}$ & & Direito \\
\hline 48. & Almeida Nogueira & $\begin{array}{l}\text { Tradições e reminiscências da Faculdade de Direito de } \\
\text { São Paulo }\end{array}$ & & História \\
\hline
\end{tabular}




\begin{tabular}{|c|c|c|c|c|}
\hline & AUTOR & TÍTULO & GÊNERO & ASSUNTO \\
\hline 49. & Aloísio de Castro & Palavras de um dia e de outro & Ensaio & Literatura Brasileira \\
\hline 50. & Alphonsus de Guimarães & Pastoral aos crentes do amor e da morte & Poema & Literatura Brasileira \\
\hline 51. & Altamirando Requião & Brutos e titãs & Romance & Literatura Brasileira \\
\hline 52. & Altino Arantes & Disse & $\begin{array}{l}\text { Discursos e } \\
\text { sermões }\end{array}$ & Literatura Brasileira \\
\hline 53. & Álvaro Mendonça & Apontamento de Direito Comercial: terrestre & & Direito Comercial \\
\hline 54. & Álvaro Moreira & Um sorriso para tudo... & Conto & Literatura Brasileira \\
\hline 55. & Amadeu Amaral & Um soneto de Bilac & Conferência & Literatura Brasileira \\
\hline 56. & Amadeu Amaral & Dante & Poema & Literatura Brasileira \\
\hline 57. & Amadeu Amaral & A pulseira de ferro & Romance & Literatura Brasileira \\
\hline 58. & Amadeu Amaral & O dialeto caipira & & Língua Portuguesa \\
\hline 59. & Amando Caiuby & Noites de plantão & Conto & Literatura Brasileira \\
\hline 60. & Amando Caiuby & Sapezais e tigueras & Conto & Literatura Brasileira \\
\hline 61. & Amaral Gurgel & O imposto do selo & & $\begin{array}{l}\text { Contabilidade e Direito } \\
\text { Comercial }\end{array}$ \\
\hline
\end{tabular}




\begin{tabular}{|c|c|c|c|c|}
\hline & AUTOR & TÍTULO & GÊENERO & ASSUNTO \\
\hline 62. & Americano do Brazil, A., comp & Cancioneiro de trovas do Brasil central & Poema & Literatura Brasileira \\
\hline 63. & Ângelo Venosa & Caramuru: poema dramático em quatro atos & Teatro & Literatura Brasileira \\
\hline 64. & Annie Bésant & O problema da morte & & Psiquismo e ocultismo \\
\hline 65. & Annie Vivanti & Vae Victis & Romance & Literatura Estrangeira \\
\hline 66. & Antônio Celestino & O padre Eusébio & Romance & Literatura Brasileira \\
\hline 67. & Antonio de Sampaio Doria & Questões de ensino & Ensaios, crítica, etc. & Educação \\
\hline 68. & Antonio de Sampaio Doria & $\begin{array}{l}\text { Como se aprende a língua - para o curso } \\
\text { complementar }\end{array}$ & & Didática \\
\hline 69. & Antonio de Sampaio Doria & Como se aprende a língua - para o curso elementar & & Didática \\
\hline 70. & Antonio de Sampaio Doria & Como se aprende a língua - para o curso médio & & Didática \\
\hline 71. & Antonio de Sampaio Doria & Como se ensina & & Didática \\
\hline 72. & Antonio de Sampaio Doria & Como se aprende a língua & & $\begin{array}{l}\text { Didática. } \\
\text { Língua Portuguesa }\end{array}$ \\
\hline 73. & Antônio de Sampaio Doria & $\begin{array}{l}\text { Instrução pelo estado: coaduna-se a instrução } \\
\text { primaria obrigatória com os princípios que regem a } \\
\text { ação social do estado }\end{array}$ & & $\begin{array}{l}\text { Didática } \\
\text { Ensino de primeiro grau }\end{array}$ \\
\hline 74. & Antônio de Sampaio Doria & A questão social & & Direito; Sociologia \\
\hline
\end{tabular}




\begin{tabular}{|c|c|c|c|c|}
\hline & AUTOR & TÍTULO & ĜENERO & ASSUNTO \\
\hline 75. & Antônio de Sampaio Doria & A revolução legal: apelo ao congresso & & Política \\
\hline 76. & Antônio de Sampaio Doria & O espírito das democracias & & Política \\
\hline 77. & Antonio de Sampaio Doria & O que todo cidadão deve saber & & Direito \\
\hline 78. & Antonio de Souza & Higiene veterinária & & Medicina veterinária \\
\hline 79. & Antonio Ferro & A idade do "Jazz-Band" & & Música \\
\hline 80. & Antônio Joaquim da Rosa & A assassina & Romance & Literatura Brasileira \\
\hline 81. & Antônio Joaquim da Rosa & A cruz de cedro & Romance & Literatura Brasileira \\
\hline 82. & Antônio Papi Junior & Sem crime & Romance & Literatura Brasileira \\
\hline 83. & Aristêo Seixas & Pôr do sol & Poema & Literatura Brasileira \\
\hline 84. & Arnaldo Damasceno Vieira & Lendas da princesa loura & Poema & Literatura Brasileira \\
\hline 85. & Arthur Motta & Vultos e livros & Biografia & Literatura Brasileira \\
\hline 86. & Ataliba Antonio de Oliveira & Maria Ângela & Romance & Literatura Brasileira \\
\hline 87. & Auguste de Saint Hilaire & São Paulo nos tempos coloniais & & História \\
\hline
\end{tabular}




\begin{tabular}{|c|c|c|c|c|}
\hline & AUTOR & TÍTULO & GÊNERO & ASSUNTO \\
\hline 88. & Augusto Andrade & Angústia: versos dolorosos & Poema & Literatura Brasileira \\
\hline 89. & Aureliano Leite & Brio de caboclo & Conto & Literatura Brasileira \\
\hline 90. & Aureliano Leite & Dias de pavor: figuras e cenas da revolta de São Paulo & & História \\
\hline 91. & Azevedo Marques & Da hipoteca & & Direito \\
\hline 92. & Batista Pereira & Rui Barbosa e o Rio Grande do Sul & & Política \\
\hline 93. & Batista Pereira & Rui, estudante & & Sociologia \\
\hline 94. & Belisário Penna & Amarelão e maleita & & Medicina \\
\hline 95. & Benedito Luis Rodrigues de Abreu & Sala dos passos perdidos & Poema & Literatura Brasileira \\
\hline 96. & Benedito M. Tolosa & Cadernos de problemas & & Didática \\
\hline 97. & Benedito M. Tolosa & Cartilha de alfabetização & & Didática \\
\hline 98. & Bento Arruda & Por campos e matas: caças, caçadas e caçadores & & Técnica. Caça e pesca. \\
\hline 99. & Bento de Faria & Pareceres & & Direito \\
\hline 100. & Bernardim Ribeiro & Menina e moça & Romance & Literatura Brasileira \\
\hline 101. & Bernardo Guimarães & O bandido do Rio das Mortes & Romance & Literatura Brasileira \\
\hline
\end{tabular}




\begin{tabular}{|c|c|c|c|c|}
\hline & AUTOR & TÍTULO & GÊNERO & ASSUNTO \\
\hline 102. & Brenno Ferraz do Amaral & Cidades vivas & Crônica & História \\
\hline 103. & Brenno Ferraz do Amaral & A guerra da independência na Bahia & & História \\
\hline 104. & Bridel & Enciclopédia Jurídica & & Direito \\
\hline 105. & C de Paiva Meira & Questão telefônica & Conferência & Direito Civil \\
\hline 106. & Candido de Figueiredo & Dicionário contemporâneo & & Dicionário \\
\hline 107. & Canto e Mello & Recordações & Romance & Literatura Brasileira \\
\hline 108. & Canto e Mello & Relíquias da memória & Romance & Literatura Brasileira \\
\hline 109. & Carlos de Carvalho & Aritmética comercial e financeira & & $\begin{array}{l}\text { Contabilidade e Direito } \\
\text { Comercial }\end{array}$ \\
\hline 110. & Carlos de Carvalho & Contabilidade agrícola & & $\begin{array}{l}\text { Contabilidade e Direito } \\
\text { Comercial }\end{array}$ \\
\hline 111. & Carlos de Carvalho & Contabilidade das companhias de seguros de vida & & $\begin{array}{l}\text { Contabilidade e Direito } \\
\text { Comercial }\end{array}$ \\
\hline 112. & Carlos de Carvalho & Estudos de contabilidade & & $\begin{array}{l}\text { Contabilidade e Direito } \\
\text { Comercial }\end{array}$ \\
\hline 113. & Carlos de Carvalho & Explicações práticas de escrituração mercantil & & $\begin{array}{l}\text { Contabilidade e Direito } \\
\text { Comercial }\end{array}$ \\
\hline 114. & Carlos de Carvalho & Noções de cálculos comerciais & & $\begin{array}{l}\text { Contabilidade e Direito } \\
\text { Comercial }\end{array}$ \\
\hline
\end{tabular}




\begin{tabular}{|c|c|c|c|c|}
\hline & AUTOR & TÍTULO & GÊNERO & ASSUNTO \\
\hline 115. & Carlos de Carvalho & Noções de cálculos comerciais e financeiros & & $\begin{array}{l}\text { Contabilidade e Direito } \\
\text { Comercial }\end{array}$ \\
\hline 116. & Carlos de Carvalho & Problemas de escrituração & & $\begin{array}{l}\text { Contabilidade e Direito } \\
\text { Comercial }\end{array}$ \\
\hline 117. & Carlos de Carvalho & Tratado elementar de contabilidade & & $\begin{array}{l}\text { Contabilidade e Direito } \\
\text { Comercial }\end{array}$ \\
\hline 118. & Carlos Dias Fernandes & A renegada & Romance & Literatura Brasileira \\
\hline 119. & Carlos Dias Fernandes & Os cangaceiros & Romance & Literatura Brasileira \\
\hline 120. & Carlos Inglez de Souza & A anarquia monetária e suas consequências & & Economia \\
\hline 121. & Carlos Ribeiro & A comédia social & & Sociologia \\
\hline 122. & Carlos Rubens & Tarântula & Conto & Literatura Brasileira \\
\hline 123. & Carolina Invernízio & Vingança de uma louca & Romance & Literatura Estrangeira \\
\hline 124. & Cecília Bandeira de Melo Vasconcelos & Gritos femininos & Conto & Literatura Brasileira \\
\hline 125. & César Martinez & Sertões do Iguaçu & & Geografia \\
\hline 126. & Cesidio Ambrogi & As moreninhas & Poema & Literatura Brasileira \\
\hline 127. & Cid Franco & Hóstia envenenada & Poema & Literatura Brasileira \\
\hline
\end{tabular}




\begin{tabular}{|c|c|c|c|c|}
\hline & AUTOR & TÍTULO & GÊNERO & ASSUNTO \\
\hline 128. & Cidade de São Paulo & Guia ilustrado do viajante & & Guia \\
\hline 129. & $\begin{array}{l}\text { Ciro Costa } \\
\text { Autor secundário: Eurico de Goes }\end{array}$ & Sob a metralha & & História \\
\hline 130. & Cleómenes Campos & Coração encantado & Poema & Literatura Brasileira \\
\hline 131. & Clóvis Ribeiro & Código comercial brasileiro & Ensaio & Direito \\
\hline 132. & Coelho Neto & Mistério & Romance & Literatura Brasileira \\
\hline 133. & Coelho Neto (Caliban) & O arara & Romance & Literatura Brasileira \\
\hline 134. & Cornélio Pires & Aventuras de Joaquim Bentinho & Conto & Literatura Brasileira \\
\hline 135. & Cornélio Pires & Conversas ao pé do fogo & Conto & Literatura Brasileira \\
\hline 136. & Cornélio Pires & Quem conta um conto... & Conto & Literatura Brasileira \\
\hline 137. & Cornélio Pires & Cenas e paisagens da minha terra & Poema & Literatura Brasileira \\
\hline 138. & Cunha Gonçalves & Da compra e venda & & Direito \\
\hline 139. & David Santos & Cartilha do comerciante & & Contabilidade \\
\hline 140. & David Santos & A letra de câmbio na contabilidade & & $\begin{array}{l}\text { Contabilidade e Direito } \\
\text { Comercial }\end{array}$ \\
\hline
\end{tabular}




\begin{tabular}{|c|c|c|c|c|}
\hline & AUTOR & TÍTULO & GÊNERO & ASSUNTO \\
\hline 141. & Diogo César de Menezes & Dicionário jurídico & & Direito \\
\hline 142. & Djalma de Andrade & Vinha ressequida & Poema & Literatura Brasileira \\
\hline 143. & Dolores Barreto & Dodóca, memórias de uma boneca & Literatura Infantil & Literatura Brasileira \\
\hline 144. & Domingo Faustino Sarmiento & Facundo & Ensaio histórico & Literatura Estrangeira \\
\hline 145. & Drury Albert Macmillen & $\begin{array}{l}\text { Solução do problema dos transportes de São Paulo ao } \\
\text { litoral }\end{array}$ & & Economia; Transporte \\
\hline 146. & Edgard Vieira & Fatoração algébrica & & $\begin{array}{l}\text { Didática. Matemática. } \\
\text { Álgebra }\end{array}$ \\
\hline 147. & Eduardo Carlos Pereira & Gramática expositiva & & Didática \\
\hline 148. & Eduardo Carlos Pereira & Gramática histórica & & $\begin{array}{l}\text { Didática. Língua } \\
\text { Portuguesa }\end{array}$ \\
\hline 149. & Eduardo Espínola & Direito de família & & Direito \\
\hline 150. & Eduardo Espínola & Questões jurídicas e pareceres & & Direito \\
\hline 151. & Eduardo Guttierez & Juan Moreira & Romance & Literatura Estrangeira \\
\hline 152. & Emilio Castellar & História de um coração & Romance & Literatura Estrangeira \\
\hline 153. & Ercília Nogueira & Virgindade anti-higiênica & Literatura Feminina & Literatura Brasileira \\
\hline
\end{tabular}




\begin{tabular}{|c|c|c|c|c|}
\hline & AUTOR & TÍTULO & GÊNERO & ASSUNTO \\
\hline 154. & Ernani Faria Alves e Leonídio Ribeiro Filho & Amputação em seção plana & & Medicina \\
\hline 155. & Ernani Macedo de Carvalho & Tratado prático de correspondência comercial & & Técnica \\
\hline 156. & Ernst Theodor Hoffmann & A máscara da morte & Romance & Literatura Estrangeira \\
\hline 157. & Euclides Bandeira & $A i$ & Poema & Literatura Brasileira \\
\hline 158. & Euclides Pereira de Andrade & Linguinhas de prata & Conto & Literatura Brasileira \\
\hline 159. & F. de Leonardo Truda & O Brasil e a Doutrina de Monroe & & História \\
\hline 160. & F. T. Souza Reis & A dívida do Brasil & Ensaios, crítica, etc. & Economia \\
\hline 161. & F. T. Souza Reis & $\begin{array}{l}\text { Padrão de câmbio ouro como solução do problema } \\
\text { monetário brasileiro }\end{array}$ & $\begin{array}{l}\text { Ensaios, críticas, } \\
\text { etc. }\end{array}$ & Economia \\
\hline 162. & F. Vergueiro Steidel & Ação ordinária & & Direito \\
\hline 163. & Fabio Luz & A paisagem no conto, na novela e no romance & Crítica & Literatura Brasileira \\
\hline 164. & Fausto Lex & A pesca & & Didática. Pesca \\
\hline 165. & Fernando Almeida Nobre & $\begin{array}{l}\text { As fronteiras do sul: a ilha Martin Garcia e a } \\
\text { jurisdição das águas do Prata }\end{array}$ & & Ciência Política \\
\hline 166. & Florence Barclay & A castelã de Shestone & Romance & Literatura Estrangeira \\
\hline
\end{tabular}




\begin{tabular}{|c|c|c|c|c|}
\hline & AUTOR & TÍTULO & GÊNERO & ASSUNTO \\
\hline 167. & Florence Barclay & O Rosário & Romance & Literatura Estrangeira \\
\hline 168. & Florence L. Barclay & Amor pelo telefone & Romance & Literatura Estrangeira \\
\hline 169. & Francisca de Basto Cordeiro & Jardim secreto & Ensaios, crítica, etc. & Literatura Brasileira \\
\hline 170. & Francisca Júlia & Esfinges & Poema & Literatura Brasileira \\
\hline 171. & Francisco D'Auria & Contabilidade de empresas diversas & & Contabilidade \\
\hline 172. & Francisco D'Auria & Matemática comercial & & Contabilidade \\
\hline 173. & Francisco D'Auria & Contabilidade bancária & & $\begin{array}{l}\text { Contabilidade e Direito } \\
\text { Comercial }\end{array}$ \\
\hline 174. & Francisco D'Auria & Contabilidade industrial & & $\begin{array}{l}\text { Contabilidade e Direito } \\
\text { Comercial }\end{array}$ \\
\hline 175. & Francisco D’Auria & Contabilidade mercantil & & $\begin{array}{l}\text { Contabilidade e Direito } \\
\text { Comercial }\end{array}$ \\
\hline 176. & Francisco Damante & O bom povo & Ensaio & Literatura Brasileira \\
\hline 177. & Francisco de Assis Cintra & Indiscrições da nossa história & & História \\
\hline 178. & Francisco de Assis Cintra & Brasil com s ou com $z ?$ & & $\begin{array}{l}\text { Língua Portuguesa } \\
\text { (filologia) }\end{array}$ \\
\hline 179. & Francisco de Assis Cintra & $\begin{array}{l}\text { O Brasil de outrora: usos, costumes e história através } \\
\text { de gravuras e documentos }\end{array}$ & & História \\
\hline
\end{tabular}




\begin{tabular}{|c|c|c|c|c|}
\hline & AUTOR & TÍTULO & GÊNERO & ASSUNTO \\
\hline 180. & Francisco Eugenio de Toledo & Análise da Constituição Federal & & Direito \\
\hline 181. & Francisco Eugenio de Toledo & Atentados ao pudor & & Direito \\
\hline 182. & Francisco Eugenio de Toledo & Constituição federal & & Direito \\
\hline 183. & Francisco Eugenio de Toledo & Manual de Direito Civil & & Direito \\
\hline 184. & Fulgêncio Claro & Memórias de Fulgêncio Claro & Romance & Literatura Brasileira \\
\hline 185. & Gabriel Marques & Os condenados & Conto & Literatura Brasileira \\
\hline 186. & Galeão Coutinho & Parque antigo & Poema & Literatura Brasileira \\
\hline 187. & Georges Ohnet & O doutor Rameau & Romance & Literatura Estrangeira \\
\hline 188. & Gilberto Amado & Aparências e realidades & Ensaio & Literatura Brasileira \\
\hline 189. & Giovanni Papini & Um homem acabado & Biografia & Literatura Estrangeira \\
\hline 190. & Giovanni Papini & História de Cristo & & Religião \\
\hline 191. & Godofredo Rangel & Andorinhas & Conto & Literatura Brasileira \\
\hline 192. & Godofredo Rangel & Vida ociosa & Romance & Literatura Brasileira \\
\hline
\end{tabular}




\begin{tabular}{|c|c|c|c|c|}
\hline & AUTOR & TÍTULO & GÊENERO & ASSUNTO \\
\hline 193. & Gottfried August Burger & Barão de Munchhausen & Literatura Infantil & Literatura Estrangeira \\
\hline 194. & Graça Aranha & Machado de Assis e Joaquim Nabuco & Crítica & Literatura Brasileira \\
\hline 195. & Graça Aranha & O espírito moderno & Ensaios, crítica, etc. & Literatura Brasileira \\
\hline 196. & Graccho Silveira & Manhã & Poema & Literatura Brasileira \\
\hline 197. & Guido da Verona & Mimi Bluette & Romance & Literatura Estrangeira \\
\hline 198. & Guilherme de Almeida & Era uma vez... & Poema & Literatura Brasileira \\
\hline 199. & Guilherme de Almeida & Livro de horas de Soror Dolorosa & Poema & Literatura Brasileira \\
\hline 200. & Gustavo Barroso & Mula sem cabeça & Conto & Literatura Brasileira \\
\hline 201. & Gustavo Barroso & Casa de maribondo & Conto & Literatura Brasileira \\
\hline 202. & Guy Chantepleure & Doida aventura & Romance & Literatura Estrangeira \\
\hline 203. & Guy Gay & Dicionário do futebol & & Técnica; Diversos \\
\hline 204. & H. Zbinden & Conselhos aos nervosos e suas famílias & & Medicina \\
\hline 205. & Hans Staden & Meu cativeiro entre os selvagens do Brasil & $\begin{array}{l}\text { Descrição de } \\
\text { viagem }\end{array}$ & Literatura Estrangeira \\
\hline
\end{tabular}




\begin{tabular}{|c|c|c|c|c|}
\hline & AUTOR & TÍTULO & GÊNERO & ASSUNTO \\
\hline 206. & Heitor Lyra & Ensaios diplomáticos & & Diplomática \\
\hline 207. & Henrique Coelho & Joaquim Nabuco & Biografia & Literatura Brasileira \\
\hline 208. & Henrique Geenen & Compendio de lógica & & Didática \\
\hline 209. & Henrique Geenen & Compendio de psicologia & & Didática \\
\hline 210. & Henrique Pérez Escrich & O mártir do gólgota & Romance & Literatura Estrangeira \\
\hline 211. & Henrique Pérez Escrish & O cura da aldeia & Romance & Literatura Estrangeira \\
\hline 212. & Henry Ford & Minha vida e minha obra & Biografia & Literatura Estrangeira \\
\hline 213. & Henry Ford & Hoje e amanhã & & Administração \\
\hline 214. & Herbert Casson & $\begin{array}{l}\text { A ciência dos negócios (os } 16 \text { mandamentos do } \\
\text { negociante) }\end{array}$ & & Técnica; Administração \\
\hline 215. & Hilário Tácito & Madame Pommery & Romance & Literatura Brasileira \\
\hline 216. & Homero Prates & Orfeu & Poema & Literatura Brasileira \\
\hline 217. & Horácio Berlink & Questões comerciais & & $\begin{array}{l}\text { Contabilidade e Direito } \\
\text { Comercial }\end{array}$ \\
\hline 218. & Horácio Berlink & Tratado de seguros & & $\begin{array}{l}\text { Contabilidade e Direito } \\
\text { Comercial }\end{array}$ \\
\hline
\end{tabular}




\begin{tabular}{|c|c|c|c|c|}
\hline & AUTOR & TÍTULO & GÊNERO & ASSUNTO \\
\hline 219. & Hugo de Carvalho Ramos & Tropas e boiadas & Conto & Literatura Brasileira \\
\hline 220. & Humberto de Campos & A bacia de Pilatos & Conto & Literatura Brasileira \\
\hline 221. & Humberto de Campos & A funda de David & Conto & Literatura Brasileira \\
\hline 222. & Humberto de Campos & A seara de booz & Conto & Literatura Brasileira \\
\hline 223. & Humberto de Campos & A serpente de bronze & Conto & Literatura Brasileira \\
\hline 224. & Humberto de Campos & Grãos de mostarda & Conto & Literatura Brasileira \\
\hline 225. & Humberto de Campos & O mealheiro de agripa & Conto & Literatura Brasileira \\
\hline 226. & Humberto de Campos & $O$ vale de Josaphat & Conto & Literatura Brasileira \\
\hline 227. & Humberto de Campos & Os gansos de Capitolio & Conto & Literatura Brasileira \\
\hline 228. & Humberto de Campos (Conselheiro XX) & O tonel de Diógenes & Conto & Literatura Brasileira \\
\hline 229. & Iainha P. Gomes & Quinze noites & Conto & Literatura Brasileira \\
\hline 230. & Ibrantina Cardona & Cleópatra & Poema & Literatura Brasileira \\
\hline 231. & Ilka Chase & Lágrimas da meia noite & Romance & Literatura Estrangeira \\
\hline
\end{tabular}




\begin{tabular}{|c|c|c|c|c|}
\hline & AUTOR & TÍTULO & GÊENERO & ASSUNTO \\
\hline 232. & J Rodrigues Valle & Pátria vindoura: em defesa do Brasil & & Politica \\
\hline 233. & J. A. Vieira Salgado & Tratado prático de prótese e mecânica dentária & & Medicina \\
\hline 234. & J. L. Mulberry & No mundo dos ladrões & Conto & Literatura Estrangeira \\
\hline 235. & J. R. Guiao & $\begin{array}{l}\text { Organização das Câmaras Municipais do Estado de } \\
\text { São Paulo }\end{array}$ & & Direito Constitucional \\
\hline 236. & Jacinto Silva (Organizador) & Guia ilustrado do viajante & & História \\
\hline 237. & Jaime de Altavila & Lógica de um burro & Conto & Literatura Brasileira \\
\hline 238. & Jean de Lery & Historia de uma viagem feita à terra do Brasil & $\begin{array}{l}\text { Descrição de } \\
\text { viagem }\end{array}$ & Literatura Estrangeira \\
\hline 239. & Jean Richepin & D. Quixote & Poema & Literatura Estrangeira \\
\hline 240. & João Barreiro & Arte grega & & História, Política e viagens \\
\hline 241. & João Batista de Sousa Filho & $\begin{array}{l}\text { Notas genealógicas sobre a família Galvão de Moura e } \\
\text { Lacerda }\end{array}$ & & Genealogia \\
\hline 242. & João Francisco & $\begin{array}{l}\text { Psicologia dos acontecimentos políticos sul- } \\
\text { riograndenses }\end{array}$ & Ensaios, crítica, etc. & Política \\
\hline 243. & João Gomes Junior & Aulas de música & & Didática \\
\hline 244. & João Gomes Junior & Cantigas de minha terra & & $\begin{array}{l}\text { Didática. } \\
\text { Música }\end{array}$ \\
\hline
\end{tabular}




\begin{tabular}{|c|c|c|c|c|}
\hline & AUTOR & TÍTULO & GÊNERO & ASSUNTO \\
\hline 245. & João Leda & Vocabulário de Rui Barbosa & & Filologia \\
\hline 246. & João Pedro da Veiga Filho & Manual da ciência das finanças & & Finanças \\
\hline 247. & João Pinto da Silva & Fisionomia de novos & Crítica & Literatura Brasileira \\
\hline 248. & João Ribeiro & Colmeia & Ensaio & Literatura Brasileira \\
\hline 249. & João Ribeiro & Notas de um estudante & Memória & Literatura Brasileira \\
\hline 250. & João Ribeiro & A língua nacional & & $\begin{array}{l}\text { Língua Portuguesa } \\
\text { (linguística; filologia) }\end{array}$ \\
\hline 251. & João Sampaio & $O$ voto secreto & Conferência & Política \\
\hline 252. & Joaquim Manoel de Macedo & A moreninha & Romance & Literatura Brasileira \\
\hline 253. & Joaquim Pereira de Camargo & Lições de taquigrafia & & Didática \\
\hline 254. & Jorge de Salis Goulart & Chuva de rosas & Poema & Literatura Brasileira \\
\hline 255. & José Antônio Nogueira & Sonho de gigante & Crítica & Literatura Brasileira \\
\hline 256. & José Antônio Nogueira & Amor imortal & Romance & Literatura Brasileira \\
\hline 257. & José Antônio Nogueira & País de ouro e esmeralda & Romance & Literatura Brasileira \\
\hline
\end{tabular}




\begin{tabular}{|c|c|c|c|c|}
\hline & AUTOR & TÍTULO & GÊNERO & ASSUNTO \\
\hline 258. & $\begin{array}{l}\text { Jose Carlos de Macedo Soares, Antonio de } \\
\text { Moraes Barros, Plinio Barreto }\end{array}$ & Acontecimentos de julho de 1924 & & História \\
\hline 259. & José Castro Nunes & A jornada revisionista & & Direito Constitucional \\
\hline 260. & José de Alencar & O tronco de Ipê & Romance & Literatura Brasileira \\
\hline 261. & José de Alencar & Ubirajara & Romance & Literatura Brasileira \\
\hline 262. & José de Sousa Soares & O militarismo na República & & História \\
\hline 263. & Jose Florencio Pereira & Sereno na flor & Poema & Literatura Brasileira \\
\hline 264. & Jose Ingenieros & Criminologia & & Direito \\
\hline 265. & $\begin{array}{l}\text { José Ingenieros e Ramon Melgar (tradução de } \\
\text { Haeckel de Lemos) }\end{array}$ & Estudos americanos & & Sociologia \\
\hline 266. & José Manoel de Azevedo Marques & A hipoteca: doutrina, processo e legislação & & Hipoteca \\
\hline 267. & José Martins & História das riquezas do clero católico e protestante & & História \\
\hline 268. & Jules Michelet & A mulher & & Sociologia \\
\hline 269. & Julio César da Silva & Conceitos e pensamentos & Citações e máximas & Literatura Brasileira \\
\hline 270. & Julio César da Silva & O diabo existe & Conto & Literatura Brasileira \\
\hline
\end{tabular}




\begin{tabular}{|c|c|c|c|c|}
\hline & AUTOR & TÍTULO & GÊNERO & ASSUNTO \\
\hline 271. & Julio César da Silva & Arte de amar & Poema & Literatura Brasileira \\
\hline 272. & Julio Ribeiro & Padre Belchior de Pontes & Romance & Literatura Brasileira \\
\hline 273. & Juscelino Barbosa & Fatos e cifras & & Economia; Finanças \\
\hline 274. & Justino de Andrade & Da posse & & Direito \\
\hline 275. & Laudo de Camargo & Notas de um juiz & & $\begin{array}{l}\text { Direito Civil } \\
\text { Jurisprudência }\end{array}$ \\
\hline 276. & Laudo de Carmargo & Pareceres & & Direito \\
\hline 277. & Léo Vaz & Ritinha & Conto & Literatura Brasileira \\
\hline 278. & Léo Vaz & O professor Jeremias & Romance & Literatura Brasileira \\
\hline 279. & Leonardo Motta & $\begin{array}{l}\text { Violeiros do Norte: poesia e linguagem do sertão } \\
\text { nordestino }\end{array}$ & & História (folclore) \\
\hline 280. & Leonardo Pinto & Conjugação de verbos italianos & & Didática \\
\hline 281. & Leonardo Pinto & $\begin{array}{l}\text { Conjugação de verbos regulares, irregulares e } \\
\text { defectivos da lingua italiana }\end{array}$ & & Didática \\
\hline 282. & Leonardo Pinto & Conjugações & & Didática \\
\hline 283. & Leonardo Pinto & Colocação dos pronomes complementos & & $\begin{array}{l}\text { Didática. } \\
\text { Língua Portuguesa } \\
\text { (gramática) }\end{array}$ \\
\hline
\end{tabular}




\begin{tabular}{|c|c|c|c|c|}
\hline & AUTOR & TÍTULO & GÊNERO & ASSUNTO \\
\hline 284. & Leonardo Pinto & Da colocação dos pronomes complementos & & $\begin{array}{l}\text { Didática. } \\
\text { Língua Portuguesa } \\
\text { (gramática) }\end{array}$ \\
\hline 285. & Leonardo Pinto & Locuções adverbiais francesas & & $\begin{array}{l}\begin{array}{l}\text { Didática. } \\
\text { Língua Portuguesa } \\
\text { (morfologia) }\end{array} \\
\end{array}$ \\
\hline 286. & Leonardo Pinto & Conjunções & & $\begin{array}{l}\text { Língua Portuguesa } \\
\text { (gramática) }\end{array}$ \\
\hline 287. & Leôncio de Oliveira & Vida roceira & Conto & Literatura Brasileira \\
\hline 288. & Leôncio Queiroz & Moléstias dos lactentes & & Medicina \\
\hline 289. & Liga Nacionalista & Combate ao jogo legal & & Direito \\
\hline 290. & Lima Barreto & Vida e morte de J. M. Gonzaga de Sá & Romance & Literatura Brasileira \\
\hline 291. & Lobão Filho & Versos que еи па̃o disse & Poema & Literatura Brasileira \\
\hline 292. & Lourenço Granato & $\begin{array}{l}\text { Adubação verde, arte antiga e ciência moderna: uma } \\
\text { revolução na economia agrícola nacional }\end{array}$ & & Ciências agrárias \\
\hline 293. & Lourenço Granato & Meteorologia e climatologia agrícola & & Ciências agrárias \\
\hline 294. & Lucillo Varejão & A mulher do próximo & Conto & Literatura Brasileira \\
\hline 295. & Lucilo Varejão & De que morreu João Feital & Romance & Literatura Brasileira \\
\hline 296. & Luis da Camara Cascudo & $\begin{array}{l}\text { Histórias que o tempo leva: da história do Rio Grande } \\
\text { do Norte }\end{array}$ & Crítica & Literatura Brasileira \\
\hline
\end{tabular}




\begin{tabular}{|c|c|c|c|c|}
\hline & AUTOR & TÍTULO & GÊNERO & ASSUNTO \\
\hline 297. & Manfredo Leite & Duas almas & $\begin{array}{l}\text { Discursos e } \\
\text { sermões }\end{array}$ & Literatura Brasileira \\
\hline 298. & Manfredo Leite & Saudades & Ensaios, crítica, etc. & Literatura Brasileira \\
\hline 299. & Manoel de Almeida & Memórias de um sargento de Milícias & Romance & Literatura Brasileira \\
\hline 300. & Manoel Vitor de Azevedo & Assombração & Conto & Literatura Brasileira \\
\hline 301. & Manuel Francisco Pinto Pereira & Casamento e divórcio & & Direito \\
\hline 302. & Manuel Galvez & Nacha regules & Romance & Literatura Estrangeira \\
\hline 303. & Manuel Maria Rodrigues & A rosa do adro & Romance & Literatura Brasileira \\
\hline 304. & Marcus Tullius Cicero & A vontade & & Psicologia \\
\hline 305. & Maria Eugênia Celso & De relance & Crônica & Literatura Brasileira \\
\hline 306. & Maria Eugênia Celso & Fantasias & Poema & Literatura Brasileira \\
\hline 307. & Maria Eugênia Celso & Vicentinho & Romance & Literatura Brasileira \\
\hline 308. & Mario dos Vanderlei & Diálogo dos abutres & Conto & Literatura Brasileira \\
\hline 309. & Mario Pinto Serva & A Alemanha saqueada & & História \\
\hline
\end{tabular}




\begin{tabular}{|c|c|c|c|c|}
\hline & AUTOR & TÍTULO & GÊNERO & ASSUNTO \\
\hline 310. & Mario Pinto Serva & A Felônia de Versalhes & & História \\
\hline 311. & Mario Pinto Serva & A próxima guerra & & História \\
\hline 312. & Mario Rodrigues & Babel & Ensaio & Literatura Brasileira \\
\hline 313. & Mario Sette & Quem vê cara... & Conto & Literatura Brasileira \\
\hline 314. & Mario Sette & Rosas e espinhos & Conto & Literatura Brasileira \\
\hline 315. & Mario Sette & O palanquim dourado & Romance & Literatura Brasileira \\
\hline 316. & Mario Sette & Senhora de engenho & Romance & Literatura Brasileira \\
\hline 317. & Martim Francisco Ribeiro de Andrada & Contribuindo & Biografia & Literatura Brasileira \\
\hline 318. & Martim Francisco Ribeiro de Andrada & Rindo & $\begin{array}{l}\text { Ensaios, críticas, } \\
\text { etc. }\end{array}$ & Literatura Brasileira \\
\hline 319. & Martinho César da Silveira Garcez & Código civil explicado & & Direito \\
\hline 320. & Martinho César da Silveira Garcez & Manual prático do processo civil e comercial & & Direito \\
\hline 321. & Martinho César da Silveira Garcez & $\begin{array}{l}\text { Manual do processo civil e comercial: teoria, prática e } \\
\text { formulários das ações civís e comerciais }\end{array}$ & & Direito Civil \\
\hline 322. & Martinho César da Silveira Garcez Filho & Direito de família & & Direito \\
\hline
\end{tabular}




\begin{tabular}{|c|c|c|c|c|}
\hline & AUTOR & TÍTULO & GÊNERO & ASSUNTO \\
\hline 323. & Martins Fontes & Volúpia & Poema & Literatura Brasileira \\
\hline 324. & Medeiros e Albuquerque & Fim & Poema & Literatura Brasileira \\
\hline 325. & Melchisedek Jehovah de Brito & Manual de jurisprudência militar & & Direito \\
\hline 326. & Melo Cunha & Algumas regras de cálculo mental & & Didática. Matemática \\
\hline 327. & Mendes Eradique & História do Brasil pelo método confuso & Conto & Literatura Brasileira \\
\hline 328. & Mendes Eradique & Lógica do absurdo & Conto & Literatura Brasileira \\
\hline 329. & Menotti del Picchia & O nariz de Cleópatra & Conto & Literatura Brasileira \\
\hline 330. & Menotti del Picchia & A angústia de Dom João & Poema & Literatura Brasileira \\
\hline 331. & Menotti Del Picchia & Amores de Dulcinéia & Poema & Literatura Brasileira \\
\hline 332. & Menotti del Picchia & Juca Mulato & Poema & Literatura Brasileira \\
\hline 333. & Menotti del Picchia & Máscaras & Poema & Literatura Brasileira \\
\hline 334. & Menotti del Picchia & Moisés & Poema & Literatura Brasileira \\
\hline 335. & Menotti del Picchia & A mulher que pecou & Romance & Literatura Brasileira \\
\hline
\end{tabular}




\begin{tabular}{|c|c|c|c|c|}
\hline & AUTOR & TÍTULO & GÊENERO & ASSUNTO \\
\hline 336. & Menotti Del Picchia & Crime daquela noite & Romance & Literatura Brasileira \\
\hline 337. & Menotti Del Picchia & Laís & Romance & Literatura Brasileira \\
\hline 338. & Menotti del Picchia & O dente de ouro & Romance & Literatura Brasileira \\
\hline 339. & Menotti Del Picchia & O homem e a morte & Romance & Literatura Brasileira \\
\hline 340. & Miguel Alves Feitosa & Ensino fundamental: primário e secundário & & Educação \\
\hline 341. & Miguel Milano & Ciências físicas e naturais & & Didática \\
\hline 342. & Miguel Nogueira & Os erros da república & & História \\
\hline 343. & Miguel Ozório de Almeida & Homens e coisas de ciência & Ensaios, crítica, etc. & Ciências fisiológicas \\
\hline 344. & Moacir Chagas & Crepúsculos & Poema & Literatura Brasileira \\
\hline 345. & Moacir de Abreu & A casa do pavor & Conto & Literatura Brasileira \\
\hline 346. & Moacir de Toledo Piza & Três campanhas & Crítica & Literatura Brasileira \\
\hline 347. & Moacir de Toledo Piza & Vespeira & Poema & Literatura Brasileira \\
\hline 348. & Monteiro Lobato & How Henry Ford is regarded in Brazil & Artigo & Literatura Brasileira \\
\hline
\end{tabular}




\begin{tabular}{|c|c|c|c|c|}
\hline & AUTOR & TÍTULO & GÊNERO & ASSUNTO \\
\hline 349. & Monteiro Lobato & Cidades Mortas & Conto & Literatura Brasileira \\
\hline 350. & Monteiro Lobato & Contos escolhidos & Conto & Literatura Brasileira \\
\hline 351. & Monteiro Lobato & Negrinha & Conto & Literatura Brasileira \\
\hline 352. & Monteiro Lobato & O macaco que se fez homem & Conto & Literatura Brasileira \\
\hline 353. & Monteiro Lobato & Os negros & Conto & Literatura Brasileira \\
\hline 354. & Monteiro Lobato & Urupês & Conto & Literatura Brasileira \\
\hline 355. & Monteiro Lobato & Ideias de Jeca Tatu & Ensaio & Literatura Brasileira \\
\hline 356. & Monteiro Lobato & A onda verde & Ensaios, crítica, etc & Literatura Brasileira \\
\hline 357. & Monteiro Lobato & Mundo da lua & Ensaios, crítica, etc. & Literatura Brasileira \\
\hline 358. & Monteiro Lobato & A caçada da onça & Literatura Infantil & Literatura Brasileira \\
\hline 359. & Monteiro Lobato & A cara de coruja & Literatura Infantil & Literatura Brasileira \\
\hline 360. & Monteiro Lobato & A menina do narizinho arrebitado & Literatura Infantil & Literatura Brasileira \\
\hline 361. & Monteiro Lobato & Aventuras do príncipe & Literatura Infantil & Literatura Brasileira \\
\hline
\end{tabular}




\begin{tabular}{|c|c|c|c|c|}
\hline & AUTOR & TÍTULO & GÊNERO & ASSUNTO \\
\hline 362. & Monteiro Lobato & Fábulas & Literatura Infantil & Literatura Brasileira \\
\hline 363. & Monteiro Lobato & Fábulas de Narizinho & Literatura Infantil & Literatura Brasileira \\
\hline 364. & Monteiro Lobato & Jeca Tatuzinho & Literatura Infantil & Literatura Brasileira \\
\hline 365. & Monteiro Lobato & Marques de Rabicó & Literatura Infantil & Literatura Brasileira \\
\hline 366. & Monteiro Lobato & Narizinho arrebitado & Literatura Infantil & Literatura Brasileira \\
\hline 367. & Monteiro Lobato & O circo de Escavalinho & Literatura Infantil & Literatura Brasileira \\
\hline 368. & Monteiro Lobato & O garimpeiro do rio das garças & Literatura Infantil & Literatura Brasileira \\
\hline 369. & Monteiro Lobato & O gato Felix & Literatura Infantil & Literatura Brasileira \\
\hline 370. & Monteiro Lobato & O irmão do Pinóquio & Literatura Infantil & Literatura Brasileira \\
\hline 371. & Monteiro Lobato & O noivado de Narizinho & Literatura Infantil & Literatura Brasileira \\
\hline 372. & Monteiro Lobato & O Saci & Literatura Infantil & Literatura Brasileira \\
\hline 373. & Monteiro Lobato & Choque das raças ou $O$ presidente negro & Romance & Literatura Brasileira \\
\hline 374. & Monteiro Lobato & $\begin{array}{l}\text { Mister Slang e o Brasil: colóquios com o inglês da } \\
\text { Tijuca }\end{array}$ & Romance & Literatura Brasileira \\
\hline
\end{tabular}




\begin{tabular}{|c|c|c|c|c|}
\hline & AUTOR & TÍTULO & GÊNERO & ASSUNTO \\
\hline 375. & Monteiro Lobato & Negros ou "ele" e o "outro" & Romance & Literatura Brasileira \\
\hline 376. & Monteiro Lobato & Fábulas & & Didática \\
\hline 377. & Monteiro Lobato & Narizinho arrebitado & & Didática \\
\hline 378. & Monteiro Lobato (adap.) & As aventuras de Hans Staden & Literatura Infantil & Literatura Brasileira \\
\hline 379. & Mucio da Paixão & Tipos, curiosidades e esquisitices dos homens célebres & Biografia & Literatura Brasileira \\
\hline 380. & Nestor Vitor & O elogio do amigo & Crítica & Literatura Brasileira \\
\hline 381. & Nilo Cairo & Veterinária homeopática & & Medicina veterinária \\
\hline 382. & Nilo Cairo & Guia prático da cultura e preparação do fumo & & Técnica; Agricultura \\
\hline 383. & Odilon Azevedo & Macegas & Conto & Literatura Brasileira \\
\hline 384. & Olavo Freire & Chorografia do Brasil & & Didática \\
\hline 385. & Oliveira e Souza & A descoberta do paraíso & Conto & Literatura Brasileira \\
\hline 386. & Oliveira Viana & Evolução do povo brasileiro & & Sociologia \\
\hline 387. & Oliveira Viana & Pequenos estudos de psicologia social & & Sociologia \\
\hline
\end{tabular}




\begin{tabular}{|c|c|c|c|c|}
\hline & AUTOR & TÍTULO & GÊNERO & ASSUNTO \\
\hline 388. & Oliveira Viana & Populações meridionais do Brasil & & Sociologia e Demografia \\
\hline 389. & Orlando C. da Silva & Enredos de história pátria & & Didática \\
\hline 390. & Oscar Cunha & Seara & Poema & Literatura Brasileira \\
\hline 391. & Oscar Wilde & O dever de matar & Conto & Literatura Estrangeira \\
\hline 392. & Oscar Wilde & O príncipe feliz & Conto & Literatura Estrangeira \\
\hline 393. & Oswald de Andrade & Os condenados - Trilogia do exílio & Romance & Literatura Brasileira \\
\hline 394. & Oswaldo Barroso & Memórias de um recruta & Conto & Literatura Brasileira \\
\hline 395. & Oswaldo Orico & A dança dos pirilampos & Poema & Literatura Brasileira \\
\hline 396. & Otacílio Gomes & Os filhos da Candinha & Poema & Literatura Brasileira \\
\hline 397. & Otávio Mendes & Direito Comercial & & $\begin{array}{l}\text { Contabilidade e Direito } \\
\text { Comercial }\end{array}$ \\
\hline 398. & Otoniel Motta & Lições de português & & Didática \\
\hline 399. & Otoniel Motta & Seleta nacional & & Didática \\
\hline 400. & Otoniel Motta & O meи idioma & & $\begin{array}{l}\text { Didática } \\
\text { (gramática) }\end{array}$ \\
\hline
\end{tabular}




\begin{tabular}{|c|c|c|c|c|}
\hline & AUTOR & TÍTULO & GÊNERO & ASSUNTO \\
\hline 401. & Otto Prazeres & Casamento a prestações & Conto & Literatura Brasileira \\
\hline 402. & Otto Rothe & Química orgânica & & Didática \\
\hline 403. & Padre Heliodoro Pires & No sorriso das almas & Ensaio & Religião \\
\hline 404. & Padre Heliodoro Pires & Nos caminhos do Nazareno & Ensaio & Religião \\
\hline 405. & Padre Heliodoro Pires & A comunhão frequente & & Religião \\
\hline 406. & Paulo da Silva Prado & Paulística & & História \\
\hline 407. & Paulo de Freitas & Os serões de dona Branca & Conto & Literatura Brasileira \\
\hline 408. & Paulo de Moraes Barros & Impressões do nordeste brasileiro & Conferência & História \\
\hline 409. & Paulo de Oliveira Setúbal & Alma Cabocla & Poema & Literatura Brasileira \\
\hline 410. & Paulo de Oliveira Setúbal & A marquesa de Santos & Romance & Literatura Brasileira \\
\hline 411. & Paulo Pinto Machado & Manhã brumosa & Poema & Literatura Brasileira \\
\hline 412. & Pedro Calmon & Pedra d'armas & Conto & Literatura Brasileira \\
\hline 413. & Pedro Lezza & Habeas Corpus & & Direito \\
\hline
\end{tabular}




\begin{tabular}{|c|c|c|c|c|}
\hline & AUTOR & TÍTULO & GÊNERO & ASSUNTO \\
\hline 414. & Pedro Saturnino & Grupiáras & Poema & Literatura Brasileira \\
\hline 415. & Peral Felix Rengel & Lei absurda & & Direito \\
\hline 416. & Philipps & Rosalina & Literatura Infantil & Literatura \\
\hline 417. & Raul de Azevedo & Senhoras e senhorinhas & Conto & Literatura Brasileira \\
\hline 418. & Raul de Freitas & Sonetaços & Poema & Literatura Brasileira \\
\hline 419. & Raul de Polillo & Kyrmah: sereia do vicio moderno & Crônica & Literatura Brasileira \\
\hline 420. & Raul de Pollilo & A dança do fogo & Romance & Literatura Brasileira \\
\hline 421. & Raul Gomes Porto & $\begin{array}{l}\text { Concreto armado: teoria e prática segundo as } \\
\text { prescrições a lemas }\end{array}$ & & Engenharia \\
\hline 422. & Reinaldo Porchat & Direito romano & & Direito \\
\hline 423. & Renato Kehl & A cura da fealdade & & Medicina \\
\hline 424. & Revista de Comércio e Indústria & Código comercial brasileiro & & $\begin{array}{l}\text { Contabilidade e Direito } \\
\text { Comercial }\end{array}$ \\
\hline 425. & Revista de Comércio e Indústria & O que todo comerciante deve saber & & $\begin{array}{l}\text { Contabilidade e Direito } \\
\text { Comercial }\end{array}$ \\
\hline 426. & Ricardo Gonçalves & Ipês & Poema & Literatura Brasileira \\
\hline
\end{tabular}




\begin{tabular}{|c|c|c|c|c|}
\hline & AUTOR & TÍTULO & GÊNERO & ASSUNTO \\
\hline 427. & Rodolfo Marcos Teófilo & $O$ reino de Kiato & Romance & Literatura Brasileira \\
\hline 428. & Rodolfo Marcos Teófilo & A sedição do juazeiro & & História \\
\hline 429. & Rodolfo von Ihering & Livros das aves & & Zoologia \\
\hline 430. & Rodolfo von Ihering & Átlas da fauna do Brasil & & Zoologia \\
\hline 431. & Roque Callage & O drama das coxilhas & Conto & Literatura Brasileira \\
\hline 432. & Rosalina Coelho Lisboa & Rito pagão & Poema & Literatura Brasileira \\
\hline 433. & Rosaura Lins & A mesa e a sobremesa & & Técnica; Livro de receitas \\
\hline 434. & Rui Barbosa & Oração aos moços & $\begin{array}{l}\text { Discursos e } \\
\text { sermões }\end{array}$ & Literatura Brasileira \\
\hline 435. & Rui Ribeiro Couto & A casa do gato cinzento & Conto & Literatura Brasileira \\
\hline 436. & Rui Ribeiro Couto & O crime do estudante Batista & Conto & Literatura Brasileira \\
\hline 437. & Rui Ribeiro Couto & O jardim das confidências & Poema & Literatura Brasileira \\
\hline 438. & Rui Ribeiro Couto & Poemetos de ternura e de melancolia & Poema & Literatura Brasileira \\
\hline 439. & Saint Hilaire & São Paulo nos tempos coloniais & & História \\
\hline
\end{tabular}




\begin{tabular}{|c|c|c|c|c|}
\hline & AUTOR & TÍTULO & GÊNERO & ASSUNTO \\
\hline 440. & Sales Oliveira & Pontos de Direito Comercial e exercícios práticos & & Direito Comercial \\
\hline 441. & Selda Potocka & A caminho da felicidade & Romance & Literatura Brasileira \\
\hline 442. & Sem nome & $\begin{array}{l}\text { As aventuras extraordinárias de Sherlock, Nick Carter } \\
\text { e Pearl White no Brasil }\end{array}$ & & Literatura Brasileira \\
\hline 443. & Sem nome & O espiritualismo cientifico e a iniciação popular & & Psiquismo e ocultismo \\
\hline 444. & Sem nome & Palavras do infinito & & Religião \\
\hline 445. & Serafim França & Cantos da linda terra dos pinheiros & Poema & Literatura Brasileira \\
\hline 446. & Silveira Bueno & Entardecer & Poema & Literatura Brasileira \\
\hline 447. & Simão de Mântua & Figurões vistos por dentro & Biografia & Literatura Brasileira \\
\hline 448. & Simão de Mântua/ Ho-He-Dgent & $\begin{array}{l}\text { Cartas de um chinês/Cartas de um chinês de Brasil } \\
\text { para a China }\end{array}$ & Conto & Literatura Estrangeira \\
\hline 449. & Sud Menucci & Alma Contemporânea & Crítica & Literatura Brasileira \\
\hline 450. & Sud Menucci & Humor & Crítica & Literatura Brasileira \\
\hline 451. & Thales de Andrade & O trabalho & & Didática \\
\hline 452. & Thales de Andrade & Saudade & & Didática \\
\hline
\end{tabular}




\begin{tabular}{|c|c|c|c|c|}
\hline & AUTOR & TÍTULO & GÊNERO & ASSUNTO \\
\hline 453. & Theo Filho & O perfume de Querubina Doria & Romance & Literatura Brasileira \\
\hline 454. & Tirso Martins & $\begin{array}{l}\text { Sedição "legalista" de Jau: defesa do Dr. João Leite } \\
\text { Ribeiro Junior }\end{array}$ & & História \\
\hline 455. & Tranquilino Leitão & Dona Glorinha & Conto & Literatura Brasileira \\
\hline 456. & Valdomiro Silveira & Os caboclos & Conto & Literatura Brasileira \\
\hline 457. & Veiga Miranda & Discursos na Câmara Federal & $\begin{array}{l}\text { Discursos e } \\
\text { sermões }\end{array}$ & $\begin{array}{l}\text { Política. Discurso } \\
\text { parlamentar }\end{array}$ \\
\hline 458. & Veiga Miranda & Os faiscadores & Ensaios, crítica, etc. & Literatura Brasileira \\
\hline 459. & Veiga Miranda & A serpente que dança & Romance & Literatura Brasileira \\
\hline 460. & Veiga Miranda & Mau olhado & Romance & Literatura Brasileira \\
\hline 461. & Veiga Miranda & Redenção & Romance & Literatura Brasileira \\
\hline 462. & Veiga Miranda & Catorze meses na pasta da marinha & & História \\
\hline 463. & Vicente de Carvalho & Luizinha & Conto & Literatura Brasileira \\
\hline 464. & Vicente de Carvalho & Poemas e canções & Poema & Literatura Brasileira \\
\hline 465. & Victor Hugo & O homem que ri & Romance & Literatura Estrangeira \\
\hline
\end{tabular}




\begin{tabular}{|c|c|c|c|c|}
\hline & AUTOR & TÍTULO & GÊNERO & ASSUNTO \\
\hline 466. & Vincenzo S. Blancato & Conte Francesco Matarazzo & Biografia & Literatura Estrangeira \\
\hline 467. & Violeta de Denis & O sonho das horas & Conto & Literatura Brasileira \\
\hline 468. & Violeta de Denis & Excitação & Poema & Literatura Brasileira \\
\hline 469. & Viriato Corrêa & Baú Velho & Crônica & Literatura Brasileira \\
\hline 470. & Viriato Corrêa & O Brasil dos meus avós & Crônica & Literatura Brasileira \\
\hline 471. & Viriato Corrêa & Balaiada & Romance & Literatura Brasileira \\
\hline 472. & Viriato Corrêa & Histórias da nossa história & & História \\
\hline 473. & Viriato Correa Filho & Evolução do erario & & Administração \\
\hline 474. & Viriato Correa Filho & Questões de ensino & & Educação \\
\hline 475. & Vivaldo Coaracy & Frida Meyer & Romance & Literatura Brasileira \\
\hline 476. & Waldemar Ferreira & A hipoteca naval do Brasil & & $\begin{array}{l}\text { Contabilidade e Direito } \\
\text { Comercial }\end{array}$ \\
\hline 477. & Waldemar Ferreira & Estudos de Direito Comercial & & $\begin{array}{l}\text { Contabilidade e Direito } \\
\text { Comercial }\end{array}$ \\
\hline 478. & Waldemar Ferreira & Manual do comerciante & & $\begin{array}{l}\text { Contabilidade e Direito } \\
\text { Comercial }\end{array}$ \\
\hline
\end{tabular}




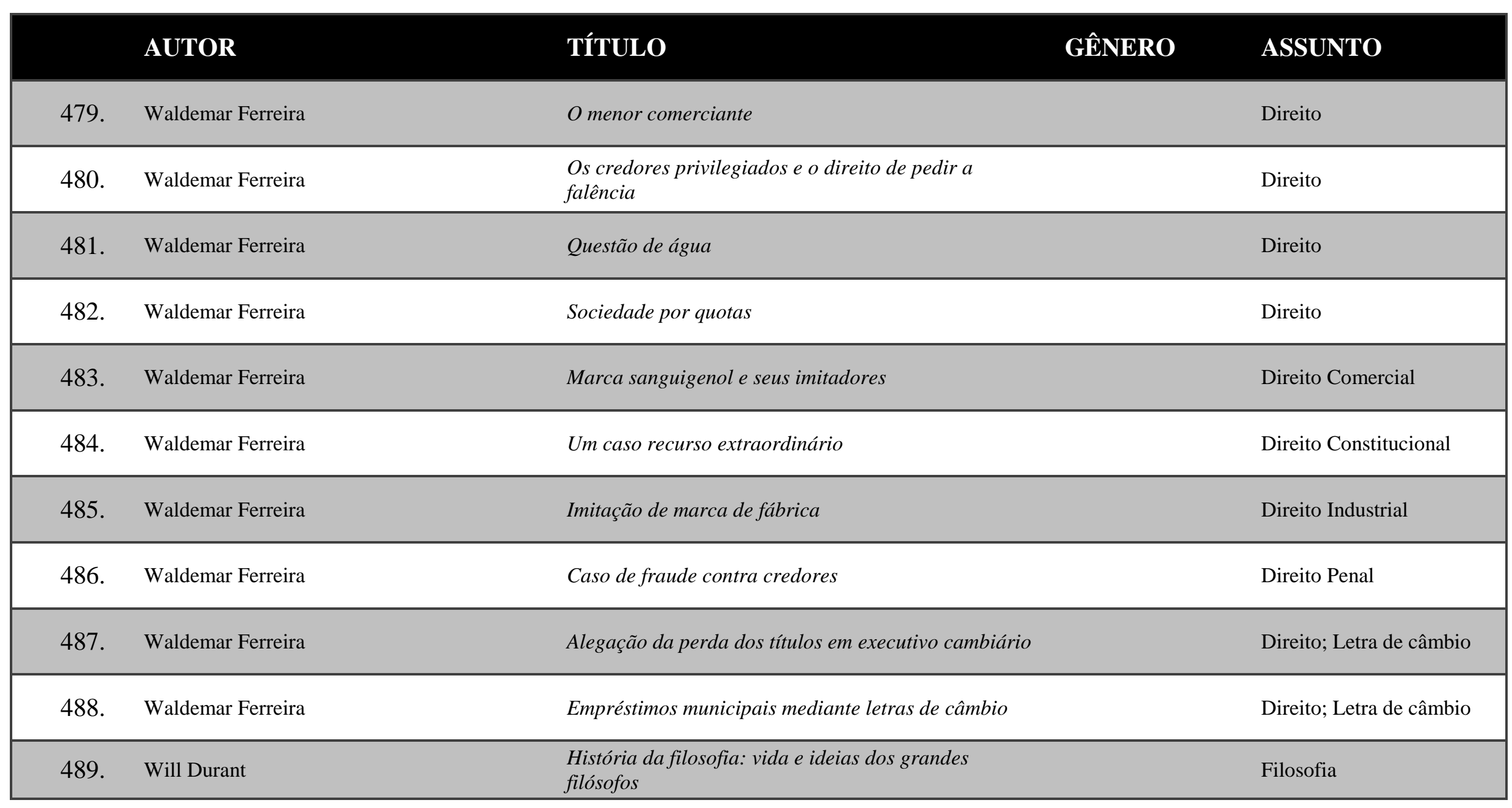




\section{Complemento F - Livros traduzidos por Monteiro Lobato}

\begin{tabular}{|c|c|c|c|c|}
\hline & AUTOR & TÍTULO TRADUZIDO & EDITORA & ANO \\
\hline 2. & Hans Staden & Meu cativeiro entre os selvagens do Brasil & Cia. Editora Nacional & 1925 \\
\hline 4. & Henry Ford & Minha vida e minha obra & Cia. Editora Nacional & 1926 \\
\hline 5. & Hans Staden & $\begin{array}{l}\text { Aventuras de Hans Staden (Contadas por Dona } \\
\text { Benta) }\end{array}$ & Cia. Editora Nacional & 1927 \\
\hline 7. & Lewis Carroll & Alice no país da maravilhas & Cia. Editora Nacional & 1931 \\
\hline 8. & Daniel Defoe & Robinson Crusoé & Cia. Editora Nacional & 1931 \\
\hline 9. & P. C. Wren & Beau Geste & Cia. Editora Nacional & 1931 \\
\hline 10. & $\begin{array}{l}\text { Jacob Ludwig Carl Grimm \& } \\
\text { Wilhelm Carl Grimm (Irmãos } \\
\text { Grimm) }\end{array}$ & Contos de Grimm & Cia. Editora Nacional & 1932 \\
\hline 13. & Lewis Carroll & Alice no país do espelho & Cia. Editora Nacional & 1933 \\
\hline 14. & Carlo Collodi & Pinocchio & Cia. Editora Nacional & 1933 \\
\hline 15. & Rudyard Kipling & Mowgli, o menino lobo & Cia. Editora Nacional & 1933 \\
\hline 16. & Jack London & Caninos brancos & Cia. Editora Nacional & 1933 \\
\hline 17. & Mayne Reid & Os negreiros da Jamaica & Cia. Editora Nacional & 1933 \\
\hline 18. & Eve Curie & Madame Curie & Cia. Editora Nacional & 1934 \\
\hline 19. & Arthur Conan Doyle & O doutor negro & Cia. Editora Nacional & 1934 \\
\hline
\end{tabular}




\section{AUTOR}

Jacob Ludwig Carl Grimm \&

20. Wilhelm Carl Grimm (Irmãos

Grimm)

21. Rudyard Kipling

22. Rudyard Kipling

23. Jack London

24. Charles Perrault

25. Eleanor H. Porter

26. Eleanor H. Porter

27. Jack London

28. Anna Sewell

29. Mark Twain

30. Mark Twain

31. Jean Webster

32. Jean Webster

33. H. G. Wells

34. E. Barrington

35. Essad Bey

36. W. R. BURNETT

37. Edgar Rice Burroughs

38. Will Durant

39. Jack London

40. Herman Melville

41. Armitage Trail
TÍTULO TRADUZIDO

Novos contos de Grimm

Jacala o crocodilo

Kim

O lobo do mar

Contos de fadas

Pollyana

Pollyana moça

A filha da neve

$O$ diamante negro

Aventuras de Huck

As viagens de Tom Sawyer

Patty

Querido inimigo

O homem invisivel

Cleópatra

A luta pelo petróleo (trad. de Charley W. Frankie com revisão de Monteiro Lobato)

O pequeno César

Tarzan, o terrivel

História da filosofia (trad. em parceria com Godofredo Rangel)

O grito da selva

Moby Dick

Scarface
Cia. Editora Nacional

1934

EDITORA

ANO

Cia. Editora Nacional 1934

Cia. Editora Nacional 1934

Cia. Editora Nacional 1934

Cia. Editora Nacional 1934

Cia. Editora Nacional 1934

Cia. Editora Nacional 1934

Cia. Editora Nacional 1934

Cia. Editora Nacional 1934

Cia. Editora Nacional 1934

Cia. Editora Nacional 1934

Cia. Editora Nacional 1934

Cia. Editora Nacional 1934

Cia. Editora Nacional 1934

Cia. Editora Nacional 1935

Cia. Editora Nacional 1935

Cia. Editora Nacional 1935

Cia. Editora Nacional 1935

Cia. Editora Nacional 1935

Cia. Editora Nacional 1935

Cia. Editora Nacional 1935

Cia. Editora Nacional 1935 


\section{AUTOR}

42. S. S. Van Dine

43. H. G. Wells

44. Thronton Wilder

45. Edgar Rice Burroughs

46. Dashiell Hammet

47. John Macy

48. S. S. Van Dine

49. Will Durant

50. Jonathan Swift

51. (tradição inglesa)

52. H. Dennis Bradley

53. Will Durant

54. Albert Einstein e Leopold Infeld

55. Oliver Lodge

56. James Truslow Adams

57. Daphne Du Maurier

58. Rudyard Kipling

59. James H. Robinson

60. Howard Spring

61. Hendrik Willem Van Loon

62. H. G. Wells

63. Warick Deeping

64. Ernest Hemingway

65. Bertrand Russel
TÍTULO TRADUZIDO

O crime no cassino

EDITORA

ANO

A ilha das almas selvagens

Ponte de São Luiz Rey

Tarzan no centro da terra

A ceia dos acusados

História da literatura mundial

O caso Garden

Filosofia da vida

Viagem de Guliver ao país dos homenzinhos de um palmo de altura

Robin Hood

Rumo às estrelas

Os grandes pensadores

A evolução da Física (revisão de Nelson Teixeira)

Raymond

A epopeia americana

Rebecca (trad. de Lígia Junqueira Smith e revisão de Monteiro Lobato)

O livro da jângal (trad. em parceria com J. Almansur Haddad)

Formação da mentalidade

Meu filho, meu filho (trad. em parceria com Lígia

Junqueira Smith)

A história da Bíblia

História do futuro

Lágrimas de homem

Por quem os sinos dobram

Educação e vida perfeita
Cia. Editora Nacional

Cia. Editora Nacional

Cia. Editora Nacional

Cia. Editora Nacional

Cia. Editora Nacional

Cia. Editora Nacional

Cia. Editora Nacional

Cia. Editora Nacional

Cia. Editora Nacional

Cia. Editora Nacional

Cia. Editora Nacional

Cia. Editora Nacional

Cia. Editora Nacional

Cia. Editora Nacional

Cia. Editora Nacional

Cia. Editora Nacional

Cia. Editora Nacional 1940

Cia. Editora Nacional 1940

Cia. Editora Nacional 1940

Cia. Editora Nacional 1940

Cia. Editora Nacional 1940

Cia. Editora Nacional 1941

Cia. Editora Nacional 1941

Cia. Editora Nacional
1935

1935

1936

1936

1936

1937

1939

1940

1940

\begin{tabular}{l}
40 \\
40 \\
40 \\
40 \\
191 \\
194 \\
\hline 41
\end{tabular}




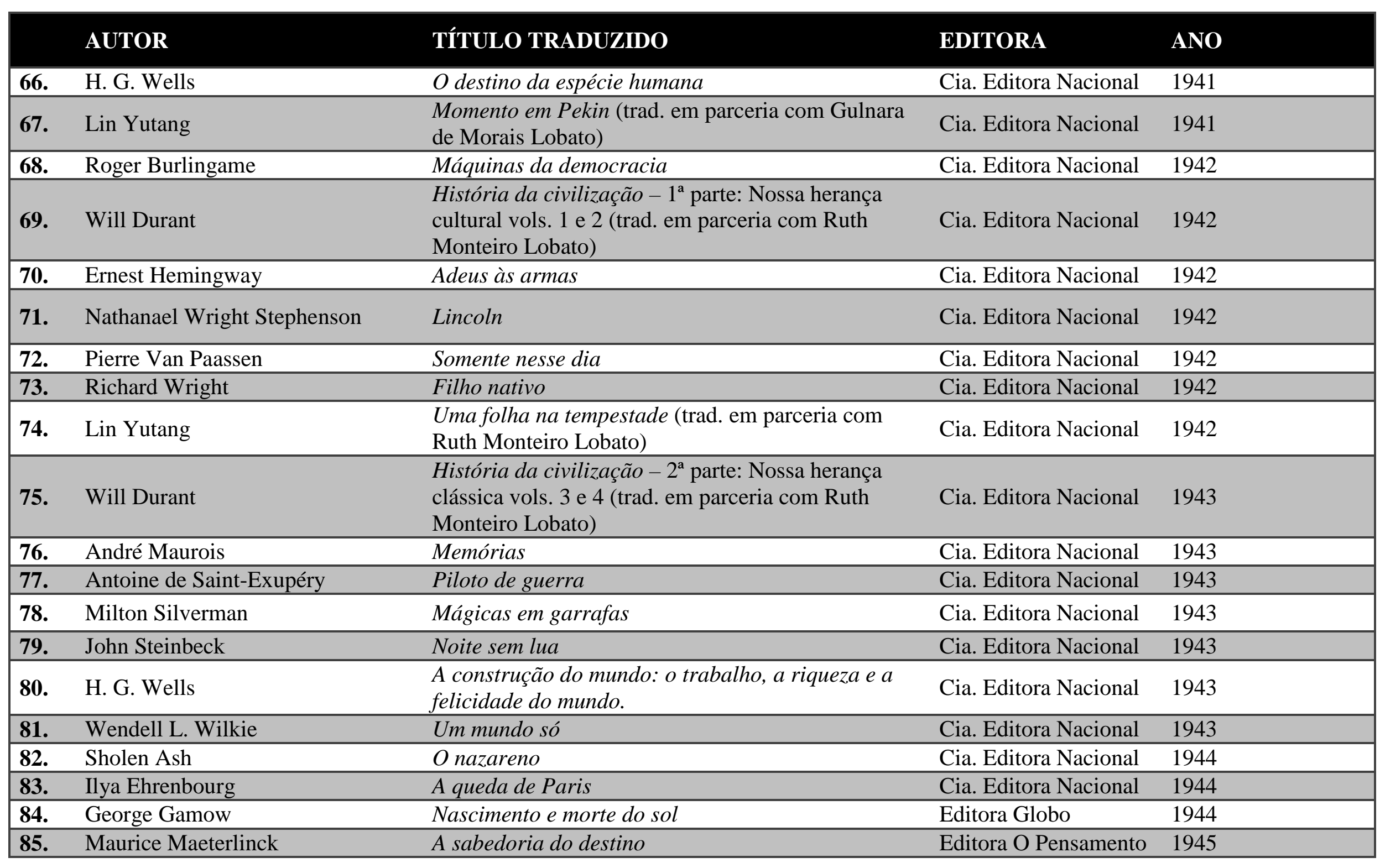


AUTOR

86. Will Durant

87. George Gamow

88. Bernard Shaw

\section{TÍTULO TRADUZIDO}

História da civilização - $3^{\mathrm{a}}$ parte: Cesar e Cristo Biografia da terra

Pigmalião - romance em cinco atos

\section{EDITORA}

ANO

Cia. Editora Nacional

Editora Globo
(datiloscrito)
1946 desconhecido desconhecido 
Complemento G - Livros doados pela família à Biblioteca Infantil Monteiro Lobato após a morte do escritor

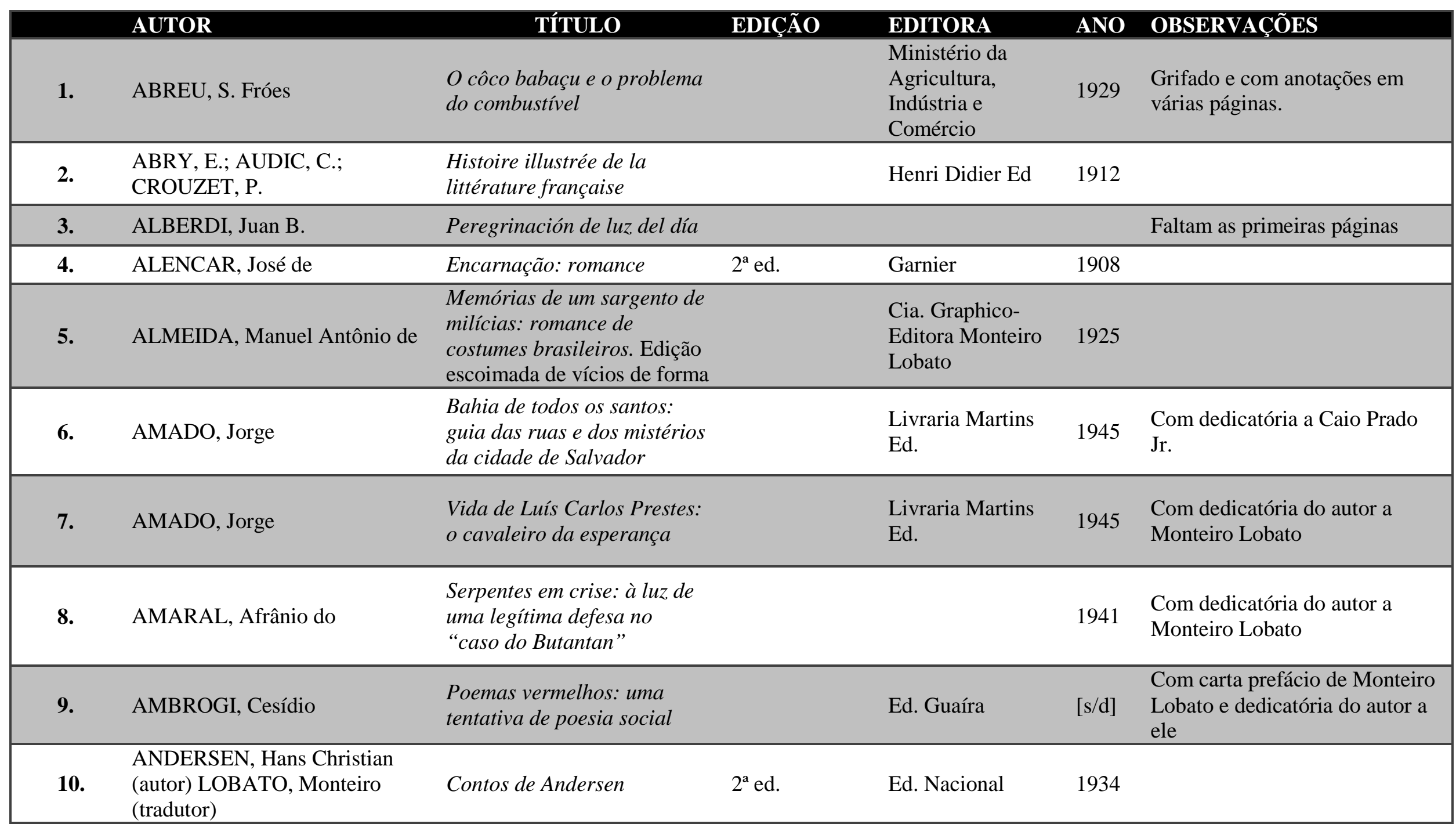




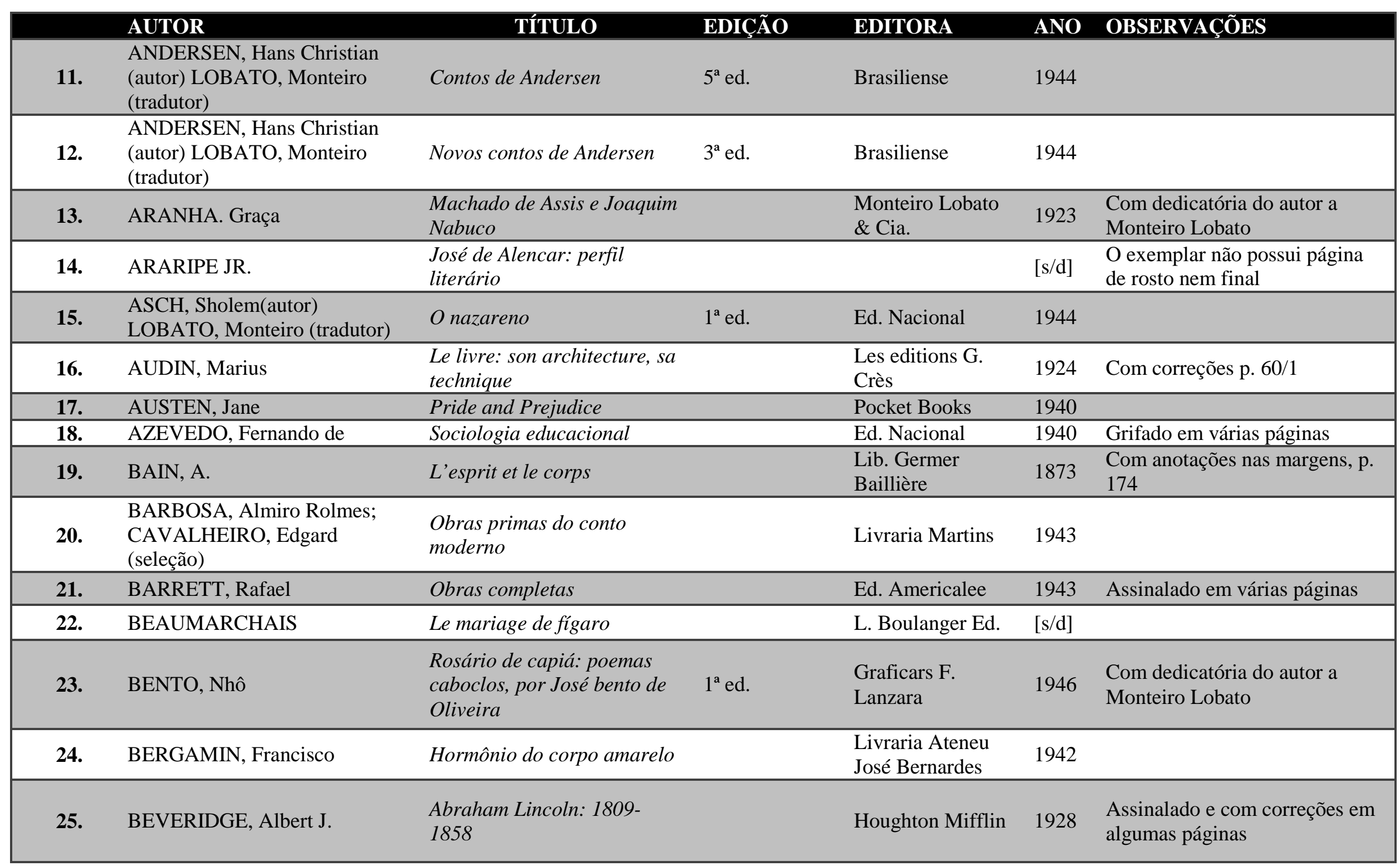




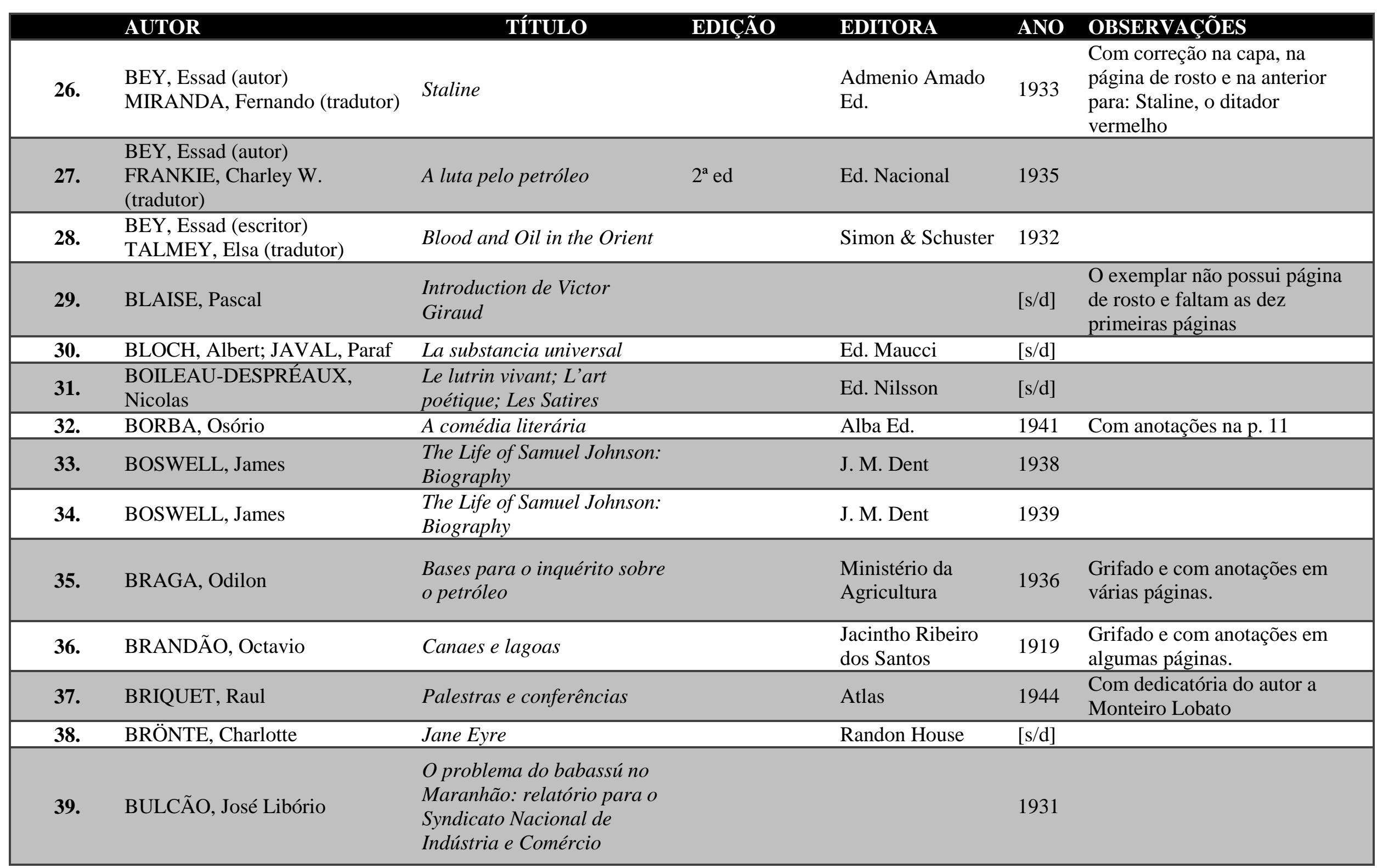




\section{AUTOR}

\begin{tabular}{|c|c|c|c|c|c|c|}
\hline & AUTOR & TÍTULO & EDIÇÃO & EDITORA & ANO & OBSERVAÇÕES \\
\hline 40. & BURGUER, G. A. & $\begin{array}{l}\text { Aventuras do Barão de } \\
\text { Münchhausen }\end{array}$ & & $\begin{array}{l}\text { Cia. Graphico } \\
\text { Editora Monteiro } \\
\text { Lobato }\end{array}$ & 1924 & $\begin{array}{l}\text { Com o nome de Edgard } \\
\text { Monteiro Lobato }\end{array}$ \\
\hline 41. & BURGUER, G. A. & $\begin{array}{l}\text { Aventuras do Barão de } \\
\text { Münchhausen }\end{array}$ & & $\begin{array}{l}\text { Cia. Graphico } \\
\text { Editora Monteiro } \\
\text { Lobato }\end{array}$ & 1924 & $\begin{array}{l}\text { Com o nome de Guilherme } \\
\text { Monteiro Lobato }\end{array}$ \\
\hline 42. & $\begin{array}{l}\text { BURGUER, G. A. (autor) } \\
\text { LOBATO, Monteiro (adaptador) }\end{array}$ & $\begin{array}{l}\text { Aventuras do Barão de } \\
\text { Münchhausen }\end{array}$ & & $\begin{array}{l}\text { [Álbum de } \\
\text { figurinhas do Café } \\
\text { Jardim] }\end{array}$ & {$[\mathrm{s} / \mathrm{d}]$} & \\
\hline 44. & CANTINHO FILHO & $\begin{array}{l}\text { Os bacharéis de 1904: } \\
\text { reminiscências }\end{array}$ & & $\begin{array}{l}\text { Faculdade de } \\
\text { Direito de São } \\
\text { Paulo }\end{array}$ & 1934 & \\
\hline 45. & $\begin{array}{l}\text { CARROL, Lewis (autor) } \\
\text { LOBATO, Monteiro (tradutor e } \\
\text { adaptador) }\end{array}$ & Alice no país das maravilhas & $5^{\mathrm{a}} \mathrm{ed}$ & Ed. Nacional & 1941 & \\
\hline 48. & CASCUDO, Luís da Câmara & $\begin{array}{l}\text { Antologia do folclore } \\
\text { brasileiro }\end{array}$ & & Livraria Martins & {$[\mathrm{s} / \mathrm{d}]$} & \\
\hline 49. & CEARENSE, Catullo da Paixão & Meu sertão & & Livraria Castilho & 1918 & $\begin{array}{l}\text { Com dedicatória do editor a } \\
\text { Monteiro Lobato }\end{array}$ \\
\hline 50. & CELSO, Maria Eugenia & Vicentinho & & $\begin{array}{l}\text { Imprensa } \\
\text { Nacional }\end{array}$ & 1924 & \\
\hline 51. & CESAR, Abelardo Vergueiro & Discursos & & $\begin{array}{l}\text { Revista dos } \\
\text { Tribunais }\end{array}$ & 1943 & $\begin{array}{l}\text { Com dedicatória do autor a } \\
\text { Monteiro Lobato }\end{array}$ \\
\hline 52. & CHAMFORT; RIVAROL & $\begin{array}{l}\text { Les hommes et les choses au } \\
\text { dix-huitième siècle }\end{array}$ & & Ed. Nilsson & {$[\mathrm{s} / \mathrm{d}]$} & Grifado em várias páginas \\
\hline 53. & $\begin{array}{l}\text { CHATEAUBRIAND, François- } \\
\text { René de }\end{array}$ & Mémoires d'outre tombe & & Garnier & {$[\mathrm{s} / \mathrm{d}]$} & Grifado em algumas páginas \\
\hline
\end{tabular}




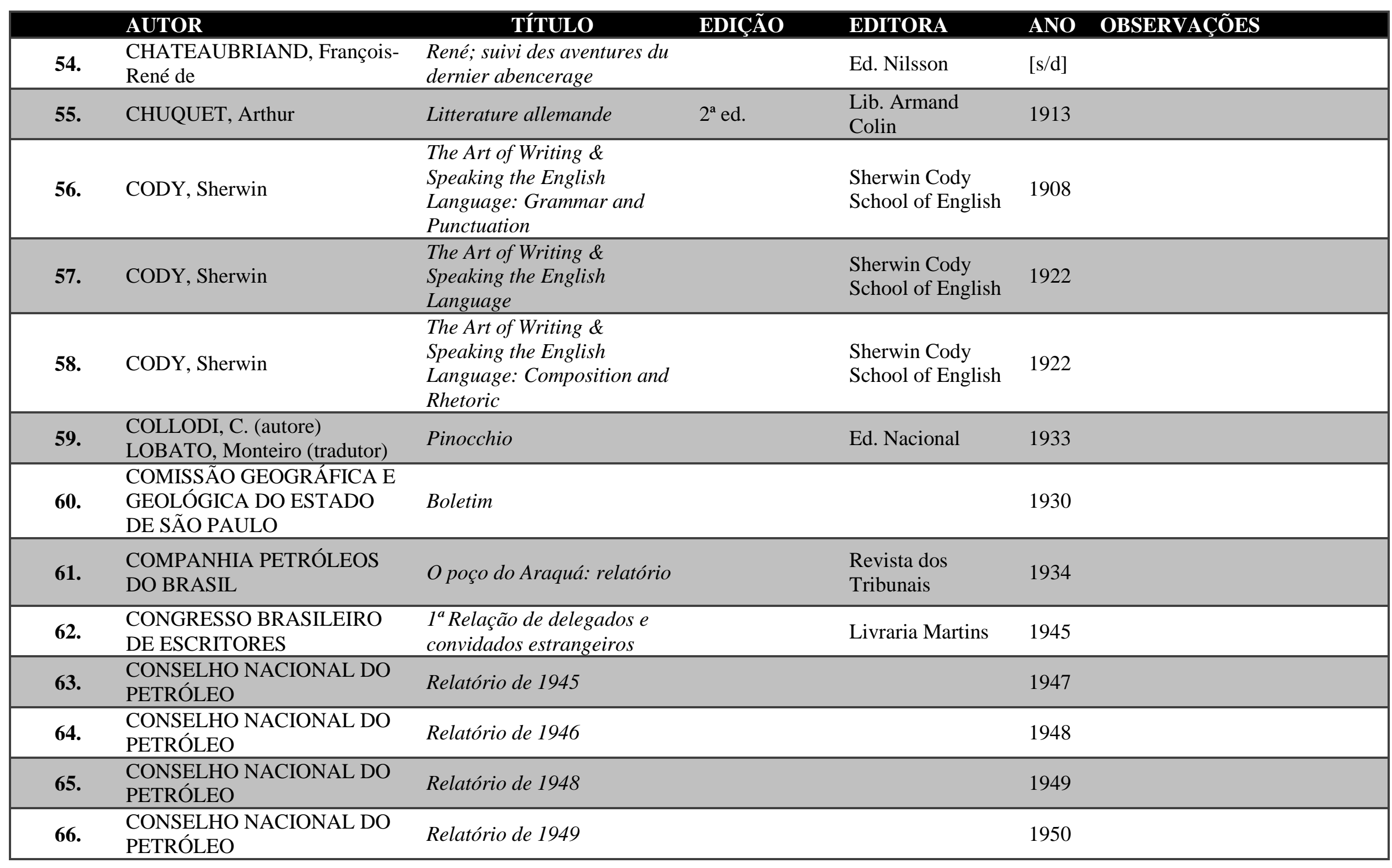




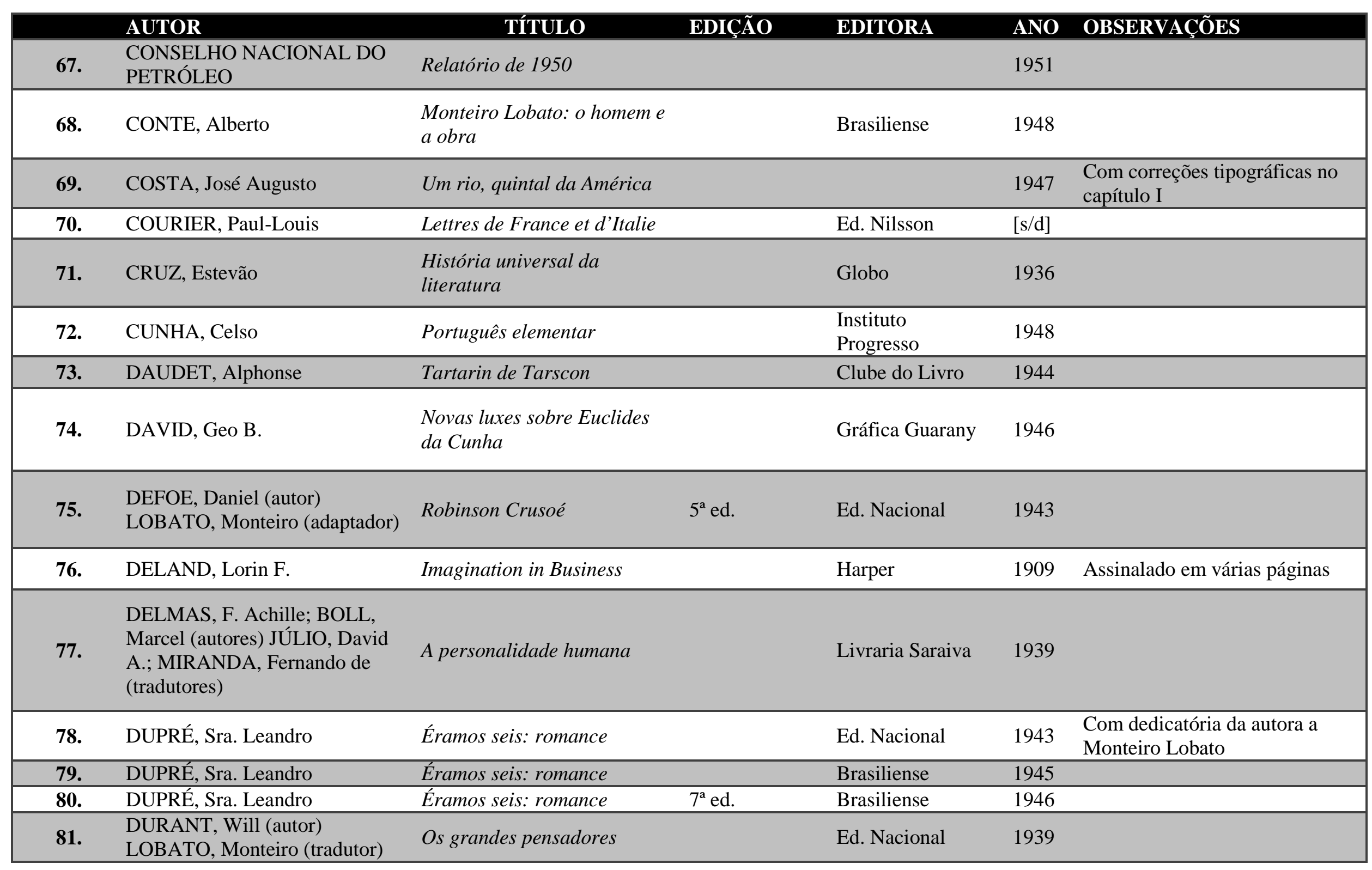




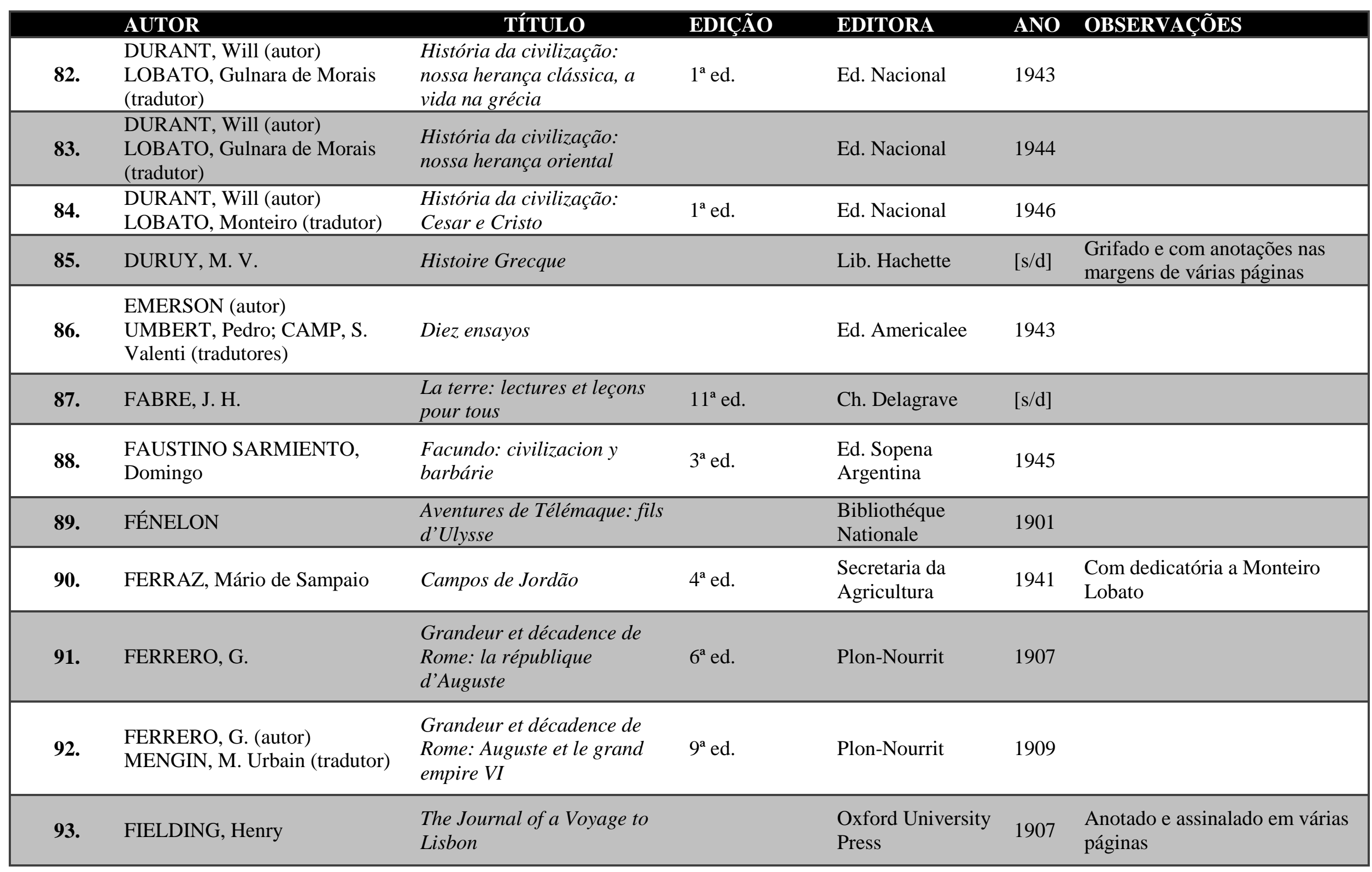




\begin{tabular}{|c|c|c|c|c|c|c|}
\hline & AUTOR & TÍTULO & EDIÇÃO & EDITORA & ANO & OBSERVAÇÕES \\
\hline 94. & FIGUEIREDO, Cândido de & Cartas inéditas & & H. Antunes & {$[\mathrm{s} / \mathrm{d}]$} & \\
\hline 95. & FIGUEIREDO, Fidelino de & $\begin{array}{l}\text { Viajantes espanhoes em } \\
\text { Portugal: textos do século } \\
\text { XVIII }\end{array}$ & & USP & 1947 & $\begin{array}{l}\text { Com dedicatória do autor a } \\
\text { Monteiro Lobato }\end{array}$ \\
\hline 96. & FILHOL, J.; BIHOREAU, Ch. & Le pétrole & & $\begin{array}{l}\text { Les editions } \\
\text { pittoresques }\end{array}$ & 1929 & \\
\hline 98. & FONTES, Martins & $\begin{array}{l}\text { Nos jardins de Augusto } \\
\text { Comte: livro posthumo }\end{array}$ & & $\begin{array}{l}\text { Comissão } \\
\text { Glorificadora de } \\
\text { Martins fontes }\end{array}$ & 1938 & \\
\hline 99. & $\begin{array}{l}\text { FORD, Henry; CROWTHER, } \\
\text { Samuel }\end{array}$ & Today and Tomorrow & & Doubleday & 1926 & $\begin{array}{l}\text { Assinalado em várias páginas; } \\
\text { Com dedicatória de Roberto a } \\
\text { Correa; }\end{array}$ \\
\hline 101. & $\begin{array}{l}\text { FORD, Henry; CROWTHER, } \\
\text { Samuel (autores) } \\
\text { FOERSTER, Arthur (tradutor) }\end{array}$ & Le progrès & & Payot & 1930 & \\
\hline 102. & $\begin{array}{l}\text { FORD, Henry; CROWTHER, } \\
\text { Samuel (autores) } \\
\text { LOBATO, Monteiro (tradutor) }\end{array}$ & Minha vida e minha obra & $3^{\mathrm{a}} \mathrm{ed}$ & Ed. Nacional & 1933 & \\
\hline 103. & FRANCE, Anatole & $\begin{array}{l}\text { Le crime de Sylvestre } \\
\text { Bonnard }\end{array}$ & & $\begin{array}{l}\text { Calmann Lévy } \\
\text { Ed. }\end{array}$ & {$[\mathrm{s} / \mathrm{d}]$} & \\
\hline 104. & FRANCE, Anatole & Histoire Comique & & $\begin{array}{l}\text { Calmann Lévy } \\
\text { Ed. }\end{array}$ & {$[\mathrm{s} / \mathrm{d}]$} & \\
\hline
\end{tabular}




\begin{tabular}{|c|c|c|c|c|c|c|}
\hline & AUTOR & TÍTULO & EDIÇÃO & EDITORA & ANO & OBSERVAÇÕES \\
\hline 105. & FRANKLIN, Benjamin & Poor Richard Almanac & & Haldeman-Julius & 1925 & \\
\hline 106. & FRIEIRO, Eduardo & A ilusão literária & & $\begin{array}{l}\text { Os Amigos do } \\
\text { Livro }\end{array}$ & 1932 & \\
\hline 107. & FUYE, M. Allotte de la & $\begin{array}{l}\text { Jules Verne: sa vie, son } \\
\text { oeuvres }\end{array}$ & $7^{\mathrm{a}}$ ed. & Simon Kra & 1928 & \\
\hline 109. & GEENEN, Henrique & $\begin{array}{l}\text { Aventuras de uma família de } \\
\text { São Paulo durante a } \\
\text { revolução de julho de } 1924\end{array}$ & & & 1925 & \\
\hline 110. & $\begin{array}{l}\text { GOETHE (escritor) } \\
\text { BITAUBÉ (tradutor) }\end{array}$ & $\begin{array}{l}\text { Hermann et Dorothée: } \\
\text { poème em IX chants }\end{array}$ & & $\begin{array}{l}\text { Bibliothéque } \\
\text { Nationale }\end{array}$ & 1896 & $\begin{array}{l}\text { Encadernado com as obras: } \\
\text { Werther, Bérénice; Bajazet, } \\
\text { Iphigénie en Aulide; Mithridate } \\
\text { e Phèdre; Britannicus }\end{array}$ \\
\hline 112. & GOLDBERG, Isaac & $\begin{array}{l}\text { Brazilian Literature, with a } \\
\text { Foreword by J. D. M. Ford }\end{array}$ & & Alfred A. Knopf & 1922 & $\begin{array}{l}\text { Com um estudo crítico sobre } \\
\text { Monteiro Lobato no cap. X }\end{array}$ \\
\hline 113. & GRANJA, Pedro & Afinal, quem somos? & & $\begin{array}{l}\text { Revista dos } \\
\text { Tribunais }\end{array}$ & 1948 & $\begin{array}{l}\text { Exemplar em papel Bouffant } \\
\mathrm{n}^{\circ} 1 \text {, rubricado pelo autor; com } \\
\text { dedicatória do autor a Monteiro } \\
\text { Lobato; homenagem a Monteiro } \\
\text { Lobato na p. } 5\end{array}$ \\
\hline 114. & GRIECO, Agrippino & Gente nova do Brasil & & José Olympio & 1935 & $\begin{array}{l}\text { A obra dedica um capítulo a } \\
\text { Monteiro Lobato, anotado e } \\
\text { grifado }\end{array}$ \\
\hline
\end{tabular}




\begin{tabular}{|c|c|c|c|c|c|c|}
\hline & AUTOR & TÍTULO & EDIÇÃO & EDITORA & ANO & OBSERVAÇÕES \\
\hline 115. & $\begin{array}{l}\text { GRIMM, J.; GRIMM, W. } \\
\text { (autores) } \\
\text { LOBATO, Monteiro (tradutor) }\end{array}$ & Contos de Grimm & $7^{\mathrm{a}}$ ed. & Ed. Nacional & 1942 & \\
\hline 117. & $\begin{array}{l}\text { GRIMM, J.; GRIMM, W. } \\
\text { (autores) } \\
\text { LOBATO, Monteiro (tradutor) }\end{array}$ & Novos contos de Grimm & $4^{\mathrm{a}}$ ed. & Ed. Nacional & 1944 & \\
\hline 119. & GUNN, John W. & $\begin{array}{l}\text { The Humor and Wisdom of } \\
\text { Abraham Lincoln }\end{array}$ & & Haldeman-Julius & 1923 & \\
\hline 120. & $\begin{array}{l}\text { HADDAD, Jamil Almansur } \\
\text { (org.) }\end{array}$ & História poética do Brasil & & $\begin{array}{l}\text { Editorial Letras } \\
\text { Brasileiras }\end{array}$ & {$[\mathrm{s} / \mathrm{d}]$} & $\begin{array}{l}\text { Com dedicatória do autor a } \\
\text { Monteiro Lobato }\end{array}$ \\
\hline 123. & $\begin{array}{l}\text { HAMILTON, D. Lee; FAHS, } \\
\text { Ned Carey (org.) }\end{array}$ & Contos do Brasil & & F. S. Crofts & 1944 & \\
\hline 124. & HERNANDEZ, Jose & $\begin{array}{l}\text { El gaucho Martin Fierro y } \\
\text { La vuelta de Matin Fierro }\end{array}$ & & Ed. Sopena & 1945 & \\
\hline 125. & $\begin{array}{l}\text { HICHTUM, Ninke Van (autor) } \\
\text { PIDGEON, Marie Kiersted }\end{array}$ & Afke's ten & & J. B. Lippincott & 1936 & \\
\hline 126. & HILLYER, V. M. & $\begin{array}{l}\text { A Child's History of the } \\
\text { World }\end{array}$ & & The Century Co. & 1924 & \\
\hline 127. & $\begin{array}{l}\text { HILLYER, V. M. (autor) } \\
\text { LOBATO, Monteiro (adaptador) }\end{array}$ & $\begin{array}{l}\text { História do mundo para as } \\
\text { crianças }\end{array}$ & $1^{\mathrm{a}} \mathrm{ed}$ & Ed. Nacional & 1933 & \\
\hline
\end{tabular}




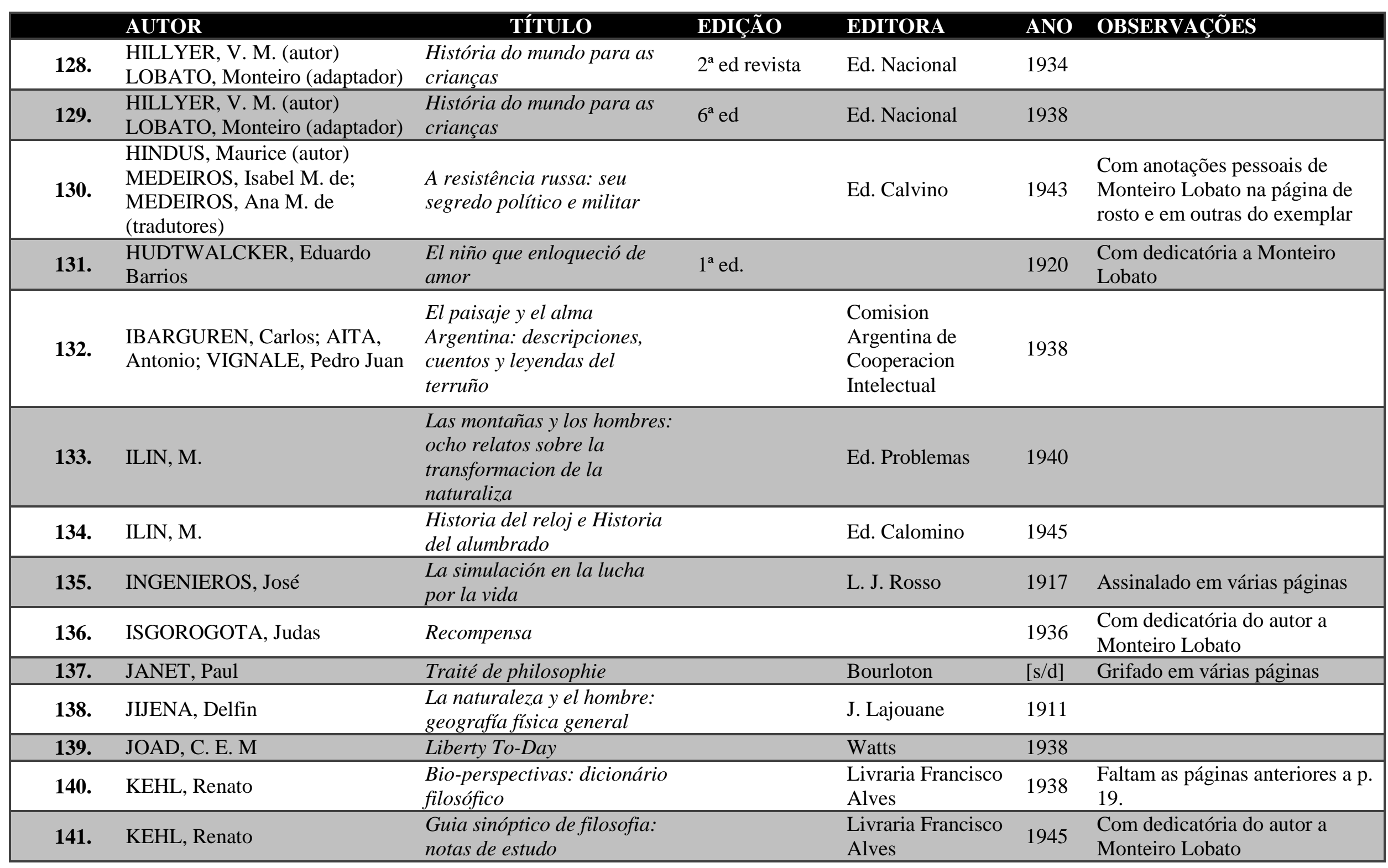




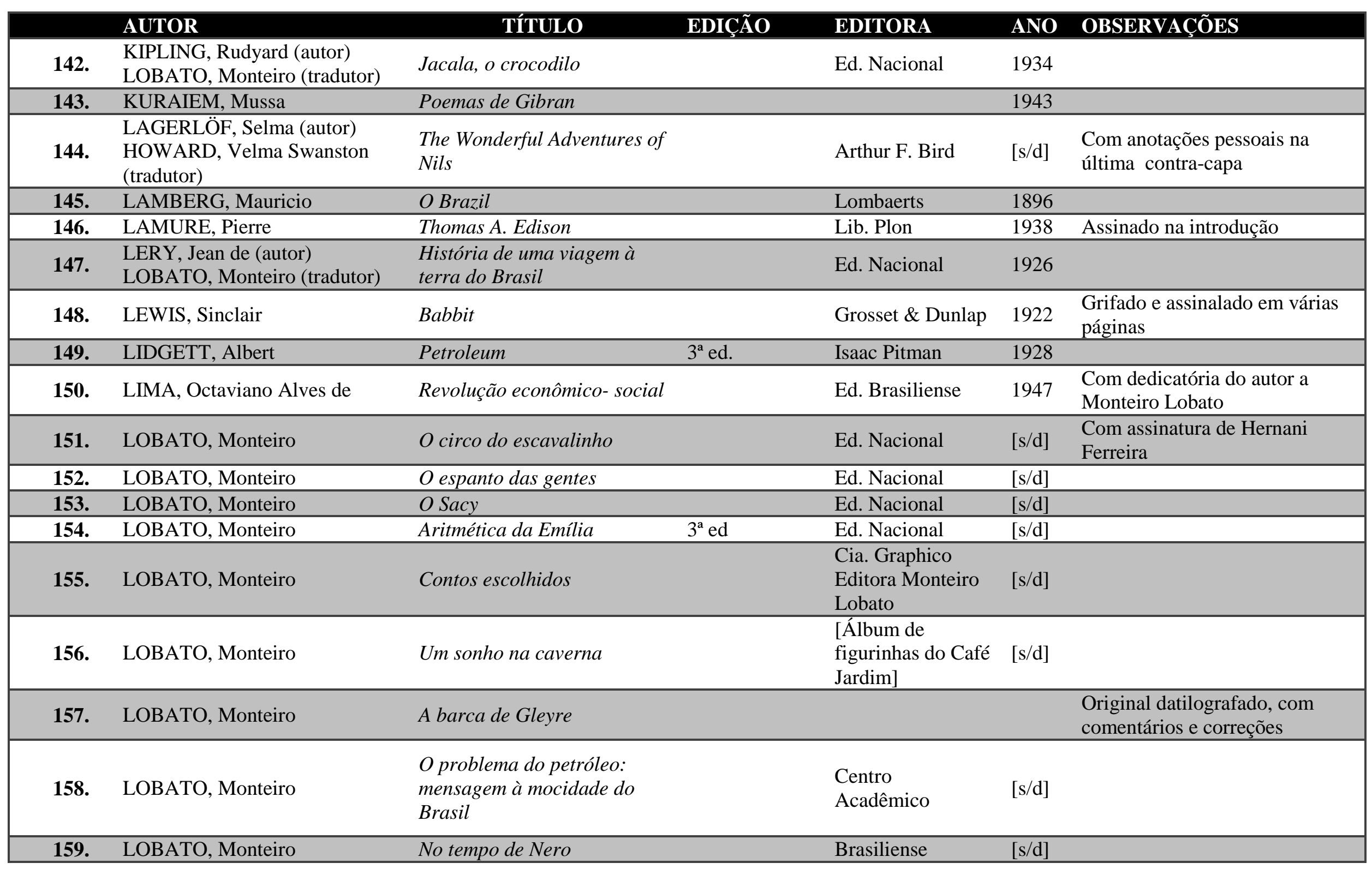




\section{AUTOR}

\begin{tabular}{|cl|}
\hline \multicolumn{2}{|c|}{ AUTOR } \\
\hline 160. & LOBATO, Monteiro \\
& \\
161. & LOBATO, Monteiro \\
\hline 162. & LOBATO, Monteiro \\
\hline $\mathbf{1 6 3}$. & LOBATO, Monteiro \\
\hline $\mathbf{1 6 4}$. & LOBATO, Monteiro \\
\hline 165. & LOBATO, Monteiro \\
\hline
\end{tabular}

TÍTULO

Las doce hazañas de Hercules

A caçada da onça: novas aventuras de Narizinho, Rabicó e demais companheiros

O centaurinho

Aventuras do príncipe O noivado de Narizinho

O marquês de Rabicó:

$\left.\begin{array}{lll}\text { terceira parte da Menina do } & 3^{\mathrm{a}} \text { ed. } & \text { Ed. Nacional }\end{array}\right]$ narizinho arrebitado

\begin{tabular}{|c|c|c|c|c|c|c|}
\hline 166. & LOBATO, Monteiro & Jéca Tatuzinho & $1^{\mathrm{a}} \mathrm{ed}$ & $\begin{array}{l}\text { Instituto } \\
\text { Medicamenta } \\
\text { Fontoura }\end{array}$ & {$[\mathrm{s} / \mathrm{d}]$} & $\begin{array}{l}\text { Dedicada às escolas como } \\
\text { colaboração do Instituto } \\
\text { Medicamenta Fontoura na } \\
\text { alfabetização da criança } \\
\text { brasileira }\end{array}$ \\
\hline 168. & LOBATO, Monteiro & Urupês & $3^{\mathrm{a}}$ ed. & $\begin{array}{l}\text { Ed. da Revista do } \\
\text { Brasil }\end{array}$ & 1918 & \\
\hline 169. & LOBATO, Monteiro & Urupês & $2^{\mathrm{a}}$ ed. & $\begin{array}{l}\text { Ed. da Revista do } \\
\text { Brasil }\end{array}$ & 1918 & \\
\hline 170. & LOBATO, Monteiro & Urupês & $1^{\mathrm{a}} \mathrm{ed}$ & Revista do Brasil & 1918 & \\
\hline 171. & LOBATO, Monteiro & $\begin{array}{l}\text { O Sacy Perêrê: resultado de } \\
\text { um inquérito }\end{array}$ & & $\begin{array}{l}\text { Secão de Obras do } \\
\text { Estado de S. } \\
\text { Paulo }\end{array}$ & 1918 & \\
\hline 172. & LOBATO, Monteiro & Urupês & $4^{\mathrm{a}} \mathrm{ed}$ & $\begin{array}{l}\text { Ed. da Revista do } \\
\text { Brasil }\end{array}$ & 1919 & \\
\hline 173. & LOBATO, Monteiro & Ideias de Jeca Tatu & & Revista do Brasil & 1919 & \\
\hline
\end{tabular}

\section{EDIÇÃO \\ EDITORA \\ ANO OBSERVAÇÕES}

Editorial Acteon $\quad[\mathrm{s} / \mathrm{d}]$

Ed. Nacional $\quad$ [s/d]

Brasiliense [s/d]

Ed. Nacional $\quad[\mathrm{s} / \mathrm{d}]$

Ed. Nacional $\quad[\mathrm{s} / \mathrm{d}]$

Instituto

edicamenta alfabetização da criança Brasil

/d]




\section{AUTOR}

\begin{tabular}{|c|c|}
\hline & AUTOR \\
\hline 175. & LOBATO, Monteiro \\
\hline 176. & LOBATO, Monteiro \\
\hline 177. & LOBATO, Monteiro \\
\hline 178. & LOBATO, Monteiro \\
\hline 179. & LOBATO, Monteiro \\
\hline 180. & LOBATO, Monteiro \\
\hline 181. & LOBATO, Monteiro \\
\hline 182. & LOBATO, Monteiro \\
\hline 183. & LOBATO, Monteiro \\
\hline 184. & LOBATO, Monteiro \\
\hline 185. & LOBATO, Monteiro \\
\hline 186. & LOBATO, Monteiro \\
\hline 187. & LOBATO, Monteiro \\
\hline 188. & LOBATO, Monteiro \\
\hline 189. & LOBATO, Monteiro \\
\hline 190. & LOBATO, Monteiro \\
\hline 191. & LOBATO, Monteiro \\
\hline 192. & LOBATO, Monteiro \\
\hline 193. & LOBATO, Monteiro \\
\hline 194. & LOBATO, Monteiro \\
\hline 195. & LOBATO, Monteiro \\
\hline 196. & LOBATO, Monteiro \\
\hline 197. & LOBATO, Monteiro \\
\hline
\end{tabular}

TÍTULO

EDIÇÃO

Cidades mortas: contos e impressões

$5^{\circ}$ milheiro EDITORA

Cidades mortas: contos e impressões

Fábulas de Narizinho Narizinho arrebitado

Urupês

Os negros ou Elle e o outro

O Sacy: livro de figuras Ideias de Jeca Tatu A onda verde Fábulas Negrinha

Urupês

Mundo da lua

O macaco que se fez homem

Jéca Tatuzinho

A caçada da onça: novas

aventuras de Narizinho, Rabicó e demais

companheiros

\begin{tabular}{|c|c|c|c|}
\hline Fábulas de Narizinho & $3^{\mathrm{a}}$ ed. & Monteiro Lobato & 1925 \\
\hline O marquês de Rabicó & & Monteiro Lobato & 1925 \\
\hline $\begin{array}{l}\text { O choque das raças ou } O \\
\text { presidente negro: romance } \\
\text { americano do ano } 2228\end{array}$ & & Ed. Nacional & 1926 \\
\hline Aventuras de Hans Staden & & Ed. Nacional & 1927 \\
\hline Fábulas & $4^{\mathrm{a}} \mathrm{ed}$ & Ed. Nacional & 1929 \\
\hline Peter Pan & & Ed. Nacional & 1930 \\
\hline A penna de papagaio & $1^{\mathrm{a}} \mathrm{ed}$ & Ed. Nacional & 1930 \\
\hline
\end{tabular}

ANO OBSERVAÇÕES

Revista do Brasil 1920

Monteiro Lobato 1921

Monteiro Lobato 1921

Monteiro Lobato 1921

Monteiro Lobato 192

\& Cia. Editora

Sociedade Editora 192

Olegário Ribeiro

1921

Monteiro Lobato 1921 Com anotações

Revista do Brasil 1922

Monteiro Lobato 1922

Monteiro Lobato 1922

Monteiro Lobato 1923

Monteiro Lobato 1923

Monteiro Lobato 1923

Monteiro Lobato 1923

Monteiro Lobato 1924

Monteiro Lobato 1924

(1)

3

24




\section{AUTOR}

\section{LOBATO, Monteiro}

199. LOBATO, Monteiro

200. LOBATO, Monteiro

201. LOBATO, Monteiro

202. LOBATO, Monteiro

203. LOBATO, Monteiro

204. LOBATO, Monteiro

205. LOBATO, Monteiro

206. LOBATO, Monteiro

207. LOBATO, Monteiro

208. LOBATO, Monteiro

209. LOBATO, Monteiro

210. LOBATO, Monteiro

211. LOBATO, Monteiro

212. LOBATO, Monteiro

213. LOBATO, Monteiro

214. LOBATO, Monteiro

215. LOBATO, Monteiro

216. LOBATO, Monteiro

217. LOBATO, Monteiro

218. LOBATO, Monteiro

219. LOBATO, Monteiro

220. LOBATO, Monteiro

221. LOBATO, Monteiro
TÍTULO

Ferro: a solução do

problema siderúrgico do

Brasil pelo processo Smith

As reinações de Narizinho

América

Die alte fazenda

As reinações de Narizinho

Novas reinações de

Narizinho

América

Emília no país da gramática

Viagem ao céu

Peter Pan

Aritmética da Emília

História das invenções

Geografia de Dona Benta

Memórias da Emília

O escandalo do Petróleo

O garimpeiro do Rio da

Garças

Viagem ao céu

América

Serões de dona Benta

O Picapau Amarelo: o sítio

de dona Benta, um mundo de $2^{\mathrm{a}} \mathrm{ed}$

verdade e de mentira

As caçadas de Pedrinho

$5^{\mathrm{a}} \mathrm{ed}$

Emília no país da gramática $\quad 4^{\mathrm{a}} \mathrm{ed}$

O garimpeiro do Rio das

Garças

A reforma da natureza
EDIÇÃO

EDITORA

ANO OBSERVAÇÕES

Ed. Nacional 1931

Ed. Nacional 1931

Ed. Nacional 1932

1932

Ed. Nacional 1933

Ed. Nacional

1933 Com correções até a p. 29

Ed. Nacional 1934

Ed. Nacional 1934

Ed. Nacional 1934

Ed. Nacional 1935

Ed. Nacional 1935

Ed. Nacional 1935

Ed. Nacional 1935

Ed. Nacional 1936

Ed. Nacional 1936

Ed. Nacional 1937

Ed. Nacional 1937 Com correções

Ed. Nacional 1937

Ed. Nacional 1937

Ed. Nacional 1939

Ed. Nacional 1939

Ed. Nacional 1940

Ed. Nacional 1940

Ed. Nacional

1941 


\begin{tabular}{|c|c|c|c|c|c|}
\hline & AUTOR & TÍTULO & EDIÇÃO & EDITORA & ANO OBSERVAÇÕES \\
\hline 222. & LOBATO, Monteiro & As caçadas de Pedrinho & $5^{\mathrm{a}}$ ed. & Ed. Nacional & 1941 \\
\hline 223. & LOBATO, Monteiro & Memórias da Emília & $3^{\mathrm{a}}$ ed. & Ed. Nacional & 1942 \\
\hline 224. & LOBATO, Monteiro & $\begin{array}{l}\text { Urupês: outros contos e } \\
\text { coisas }\end{array}$ & $\begin{array}{l}\text { Comemorativa } \\
\text { do } 25^{\circ} \\
\text { aniversário da } \\
\text { estreia do } \\
\text { escritor }\end{array}$ & Ed. Nacional & 1943 \\
\hline 227. & LOBATO, Monteiro & O minotauro & $3^{\mathrm{a}} \mathrm{ed}$ & Brasiliense & 1944 \\
\hline 228. & LOBATO, Monteiro & História das invenções & $4^{\mathrm{a}} \mathrm{ed}$ & Ed. Nacional & 1944 \\
\hline 229. & LOBATO, Monteiro & Geografia de Dona Benta & $5^{\mathrm{a}} \mathrm{ed}$ & Ed. Nacional & 1944 \\
\hline 230. & LOBATO, Monteiro & Aventuras de Hans Staden & $5^{\mathrm{a}} \mathrm{ed}$ & Ed. Nacional & 1944 \\
\hline 231. & LOBATO, Monteiro & O leão de Neméia & & Brasiliense & 1944 \\
\hline 232. & LOBATO, Monteiro & A hidra de Lerna & & Brasiliense & 1944 \\
\hline 237. & LOBATO, Monteiro & O touro de Creta & & Brasiliense & 1944 \\
\hline 238. & LOBATO, Monteiro & Os cavalos de Diomedes & & Brasiliense & 1944 \\
\hline 239. & LOBATO, Monteiro & O cinto de Hipolita & & Brasiliense & 1944 \\
\hline 240. & LOBATO, Monteiro & Os bois de Gerião & & Brasiliense & 1944 \\
\hline 241. & LOBATO, Monteiro & O pomo das Hesperides & & Brasiliense & 1944 \\
\hline 242. & LOBATO, Monteiro & Hércules e Cérbero & & Brasiliense & 1944 \\
\hline 243. & LOBATO, Monteiro & $\begin{array}{l}\text { D. Quixote das crianças: } \\
\text { contado por Dona Benta }\end{array}$ & $3^{\mathrm{a}}$ ed. & Brasiliense & 1944 \\
\hline 244. & LOBATO, Monteiro & As caçadas de Pedrinho & $6^{\mathrm{a}}$ ed. & Ed. Nacional & 1944 \\
\hline 245. & LOBATO, Monteiro & $\begin{array}{l}\text { Serões de dona Benta: física } \\
\text { e astronomia }\end{array}$ & $3^{\mathrm{a}}$ ed. & Brasiliense & 1944 \\
\hline
\end{tabular}




\section{AUTOR}

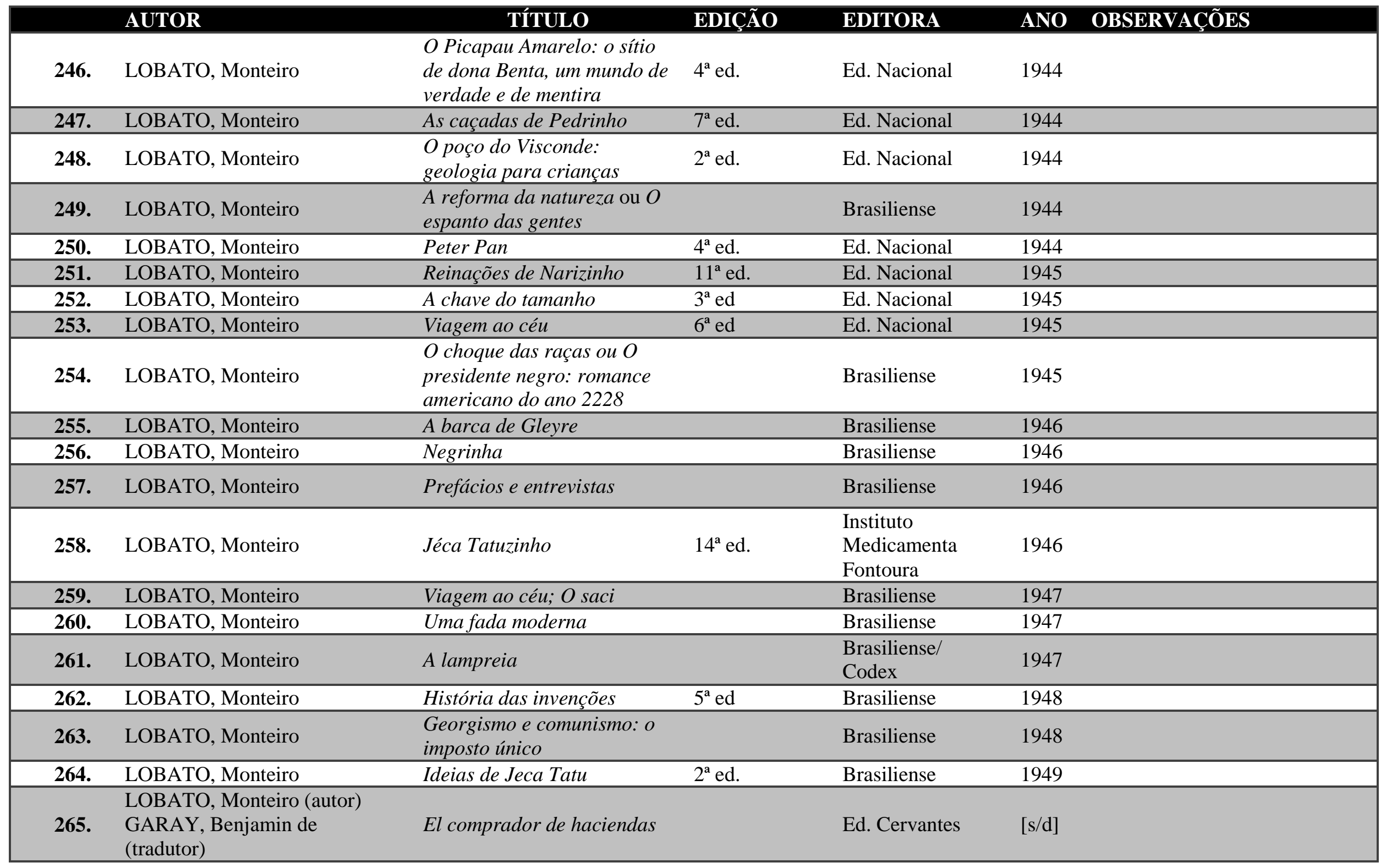




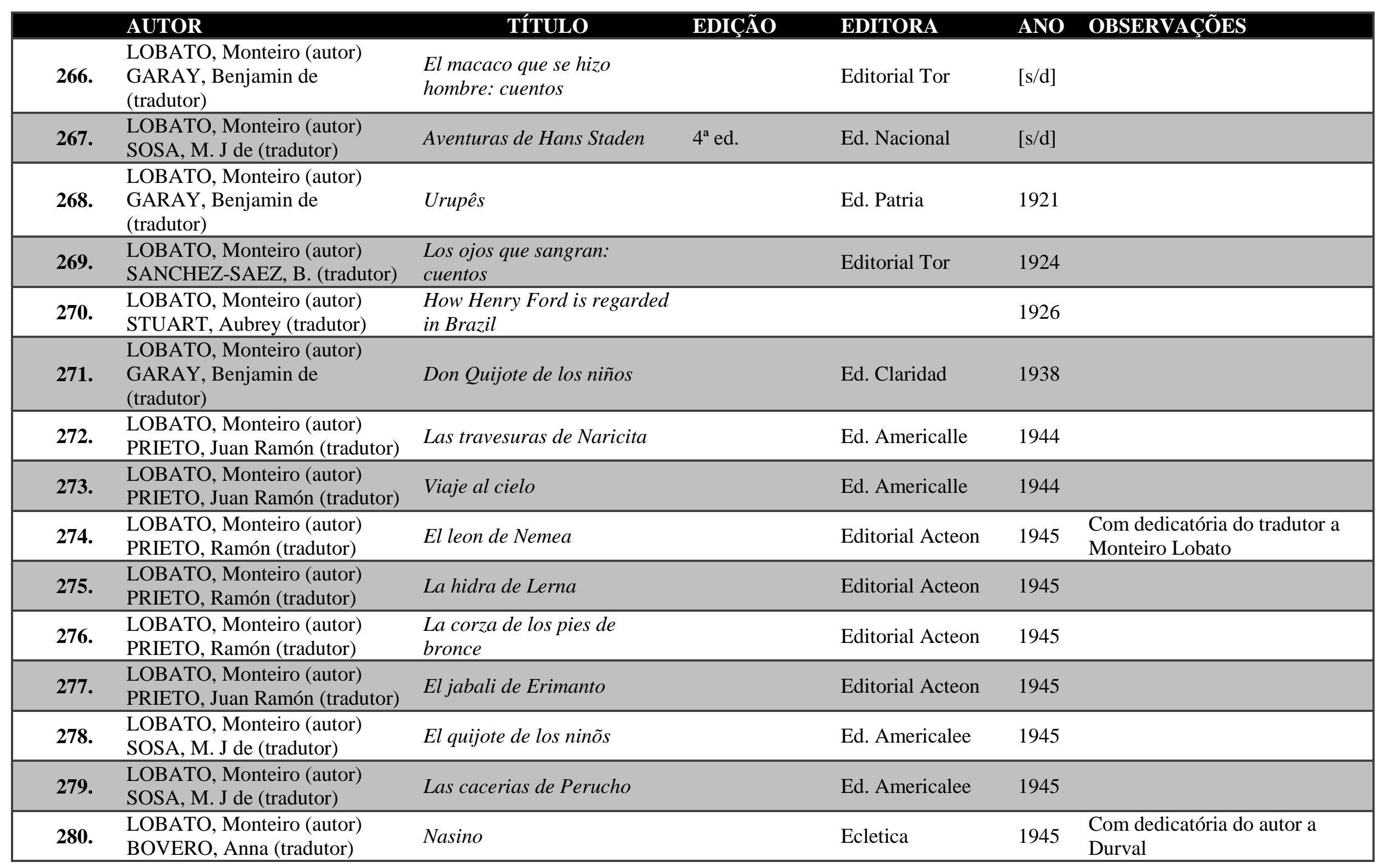




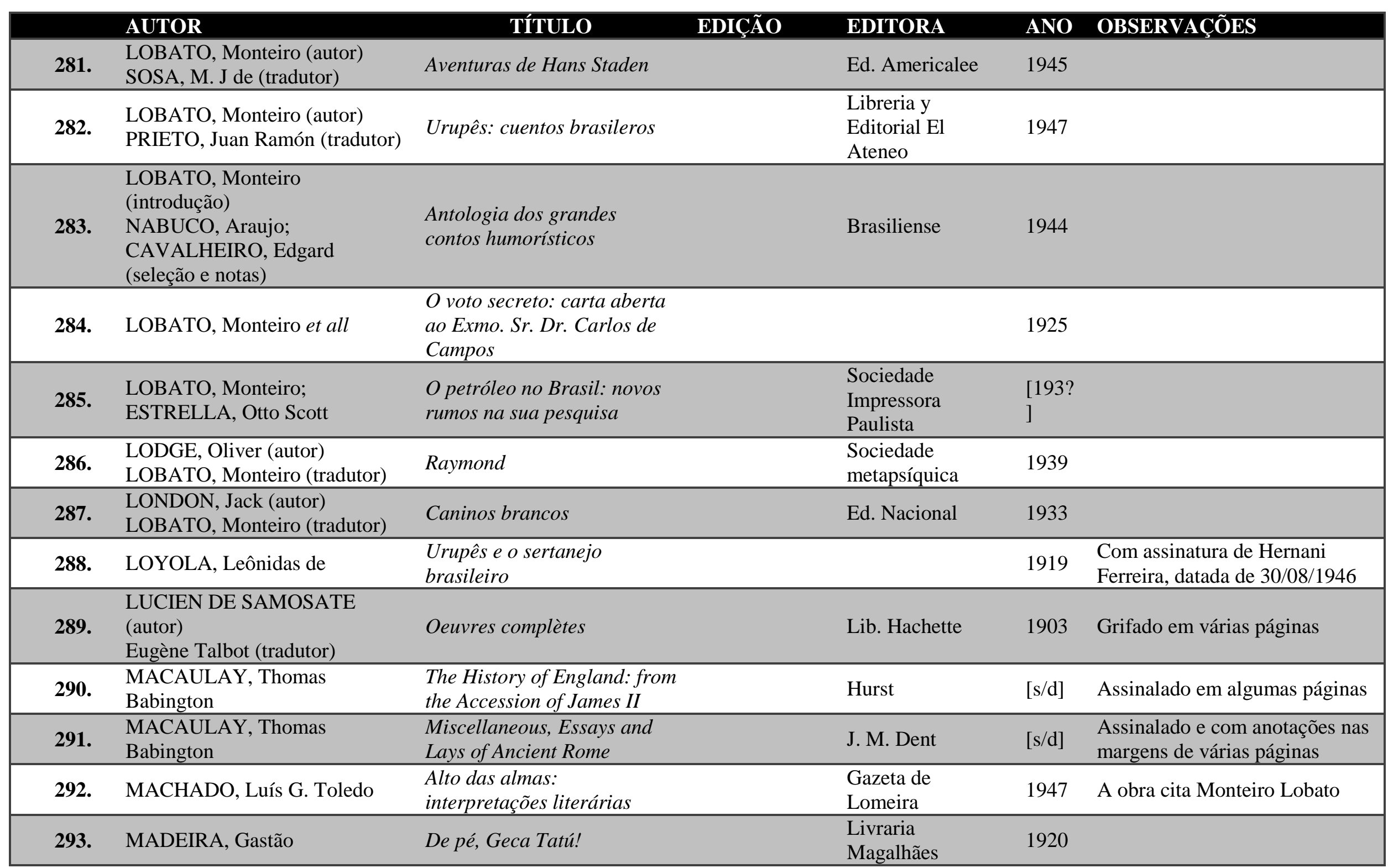




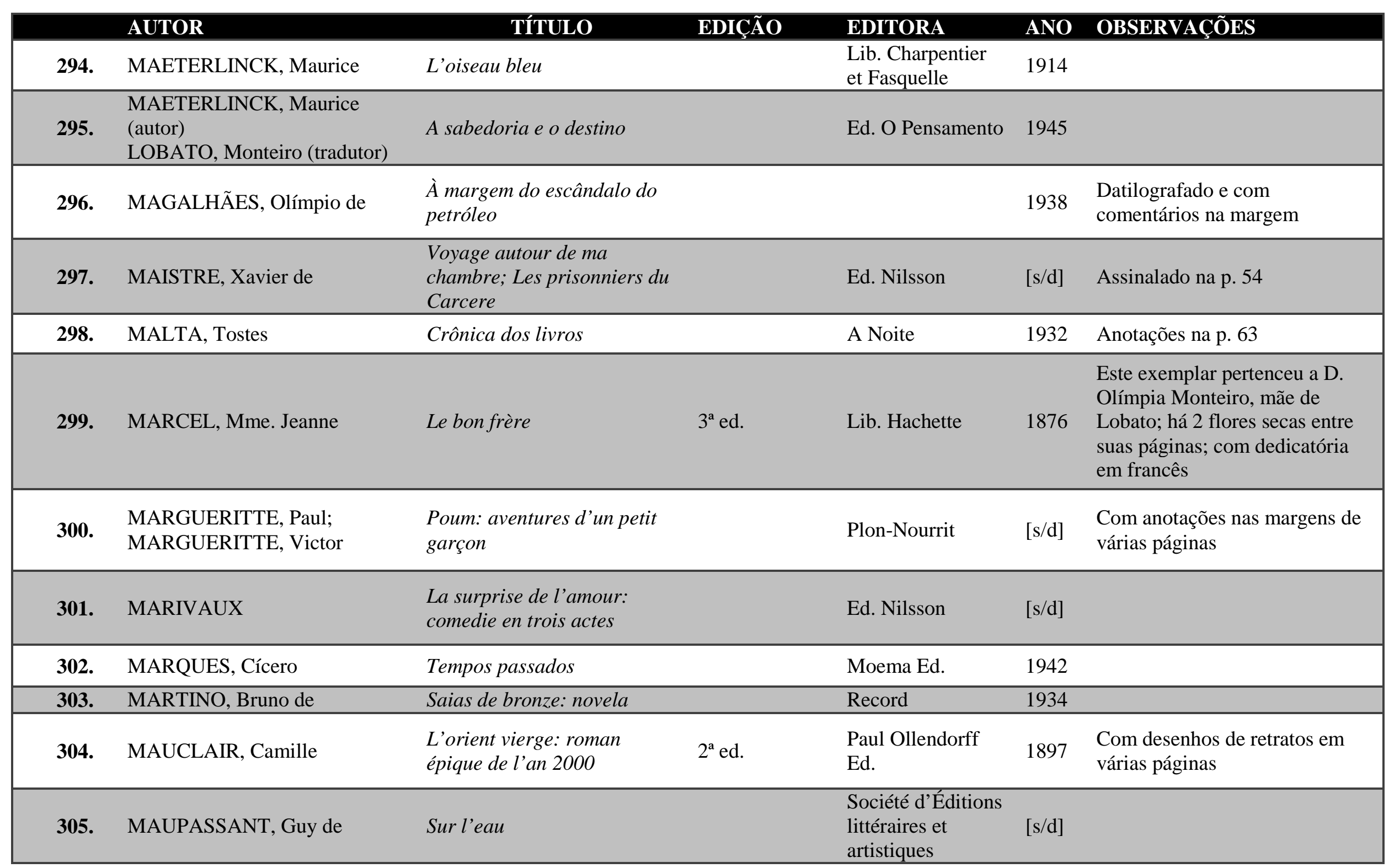




\section{AUTOR}

TÍTULO

\begin{tabular}{|c|c|}
\hline 306. & MAUPASSANT, Guy de \\
\hline 307. & $\begin{array}{l}\text { MAUROIS, André (autor) } \\
\text { LOBATO, Monteiro (tradutor) }\end{array}$ \\
\hline 308. & MAZÉ, P. \\
\hline 309. & MEINEL, Josephina (coord.) \\
\hline 310. & MELLO, Robespierre de \\
\hline 311. & MELO, Aníbal Vaz de \\
\hline 312. & MENEZES, Diogo de Melo \\
\hline 313. & MILBURN, George \\
\hline 314. & MONTAIGNE, Michel de \\
\hline 315. & $\begin{array}{l}\text { MORTILLARO, Gaspar; } \\
\text { ELIZONDO, Ramón T. }\end{array}$ \\
\hline
\end{tabular}

Le horla

Memórias

Libelo da gleba

Sinais dos tempos

a M. Villemain sur
EDIÇÃO

EDITORA

ANO OBSERVAÇÕES

Société d'Éditions

littéraires et

artistiques

Ed. Nacional 1943

[s/d]

320. NOVICOW, J.
Évolution du carbone et

l'azote dans le monde vivant

Contos da carochinha

Gilberto Freyre

The Best Yankee Jokes

Essais, précédés d'une lettre

Elementos para iniciación

literaria y Diccionario bio-

bibliografico de autores

argentinos y americanos

Cantadores: poesia e

linguagem do sertão

cearense

Contes

Paradoxos

Le royaume des cieux: um peu du secret des étoiles

Les lutes entre societies

Gauthier Villars

1889 Grifado em várias páginas

1925

1945

Com dedicatória do autor a

aumentada

1948 Monteiro Lobato successives
Livraria Castilho 1921

Jean Gillequin $\quad$ [s/d]

Ed. Unitas $\quad[\mathrm{s} / \mathrm{d}]$

Lib. Hachette

[s/d]

Exemplar sem capa e sem as páginas 1-12

Grifado e com anotações em várias páginas

Félix Alcan Ed. 1893 


\section{AUTOR}

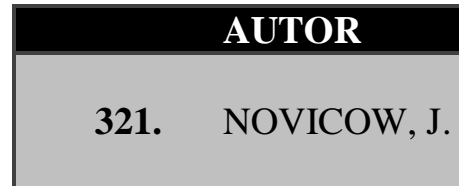

La justice et l'expansion de des sociétés humaines

\begin{tabular}{|c|c|c|c|c|c|c|}
\hline 322. & O'NEILL, Eugene & Strange Interlude & & Boni \& Liveright & 1928 & $\begin{array}{l}\text { Com anotações em algumas } \\
\text { páginas }\end{array}$ \\
\hline 323. & OITICICA, José & Manual de estilo & $4^{\mathrm{a}} \mathrm{ed}$ & $\begin{array}{l}\text { Livraria Francisco } \\
\text { Alves }\end{array}$ & 1940 & \\
\hline 324. & $\begin{array}{l}\text { OLIVARI, Nicolas; } \\
\text { STANCHINA, Lorenzo }\end{array}$ & $\begin{array}{l}\text { Manuel Gálvez: ensayo } \\
\text { sobre su obra }\end{array}$ & & $\begin{array}{l}\text { Agencia General } \\
\text { de Librería y } \\
\text { Publicaciones }\end{array}$ & 1924 & \\
\hline 325. & $\begin{array}{l}\text { OSTWALD, W. (autor) } \\
\text { PHILIPPI, E. (tradutor) }\end{array}$ & L'énergie & & Félix Alcan Ed. & 1924 & $\begin{array}{l}\text { Com dedicatória de Venâncio a } \\
\text { Anísio; assinalado em algumas } \\
\text { páginas }\end{array}$ \\
\hline 326. & PAIM, H. Nobil & $\begin{array}{l}\text { Sauvão: o problema vital do } \\
\text { ensino obrigatório na zona } \\
\text { tropical }\end{array}$ & & $\begin{array}{l}\text { Livraria Cristo- } \\
\text { Rei }\end{array}$ & 1945 & \\
\hline 327. & PEDREIRA, Aurélio de Bulhões & A pesquisa do petróleo & & $\begin{array}{l}\text { Typographia do } \\
\text { "Annuario do } \\
\text { Brasil" }\end{array}$ & 1927 & \\
\hline 328. & PEIXOTO, Silveira & Falam os escritores & & Ed. Guaíra & 1941 & \\
\hline 329. & PENTEADO, Eurico & Xadrez elementar & $3^{\mathrm{a}} \mathrm{ed}$ & Ed. Brasileira & {$[\mathrm{s} / \mathrm{d}]$} & \\
\hline 330. & PEPYS, Samuel & Pepys' Diary & & J. M. Dent & 1939 & \\
\hline 331. & PEPYS, Samuel & Pepys' Diary & & J. M. Dent & 1940 & \\
\hline 332. & PEREIRA, Lúcia Miguel & $\begin{array}{l}\text { Machado de Assim: estudo } \\
\text { crítico e biográfico }\end{array}$ & & Ed. Nacional & 1936 & $\begin{array}{l}\text { Com correções tipográficas em } \\
\text { várias páginas }\end{array}$ \\
\hline 333. & PEREIRA, Urbano & $\begin{array}{l}\text { Nós e o universo: o senso da } \\
\text { vida }\end{array}$ & & Ed. Nacional & 1942 & $\begin{array}{l}\text { Com dedicatória do autor a } \\
\text { Monteiro Lobato }\end{array}$ \\
\hline 334. & $\begin{array}{l}\text { PERRAULT, Charles (autor) } \\
\text { LOBATO, Monteiro (tradutor) }\end{array}$ & Contos de fadas & $2^{a}$ ed. & Ed. Nacional & 1937 & \\
\hline 335. & $\begin{array}{l}\text { PERRAULT, Charles (autor) } \\
\text { LOBATO, Monteiro (tradutor) }\end{array}$ & Contos de fadas & $3^{\mathrm{a}}$ ed. & Ed. Nacional & 1939 & \\
\hline
\end{tabular}

TÍTULO

la vie: essai sur le bonheur

\section{EDIÇÃO \\ EDITORA \\ ANO OBSERVAÇÕES}

Félix Alcan Ed. 1905 Grifado em várias páginas

Boni \& Liveright 1928 Com anotações em algumas

Agencia General

de Librería y

assinalado em algumas

Sauvão: o problema vital do

ensino obrigatório na zona

Livraria Cristo-

ypographia do

Brasil"

Guaíra 


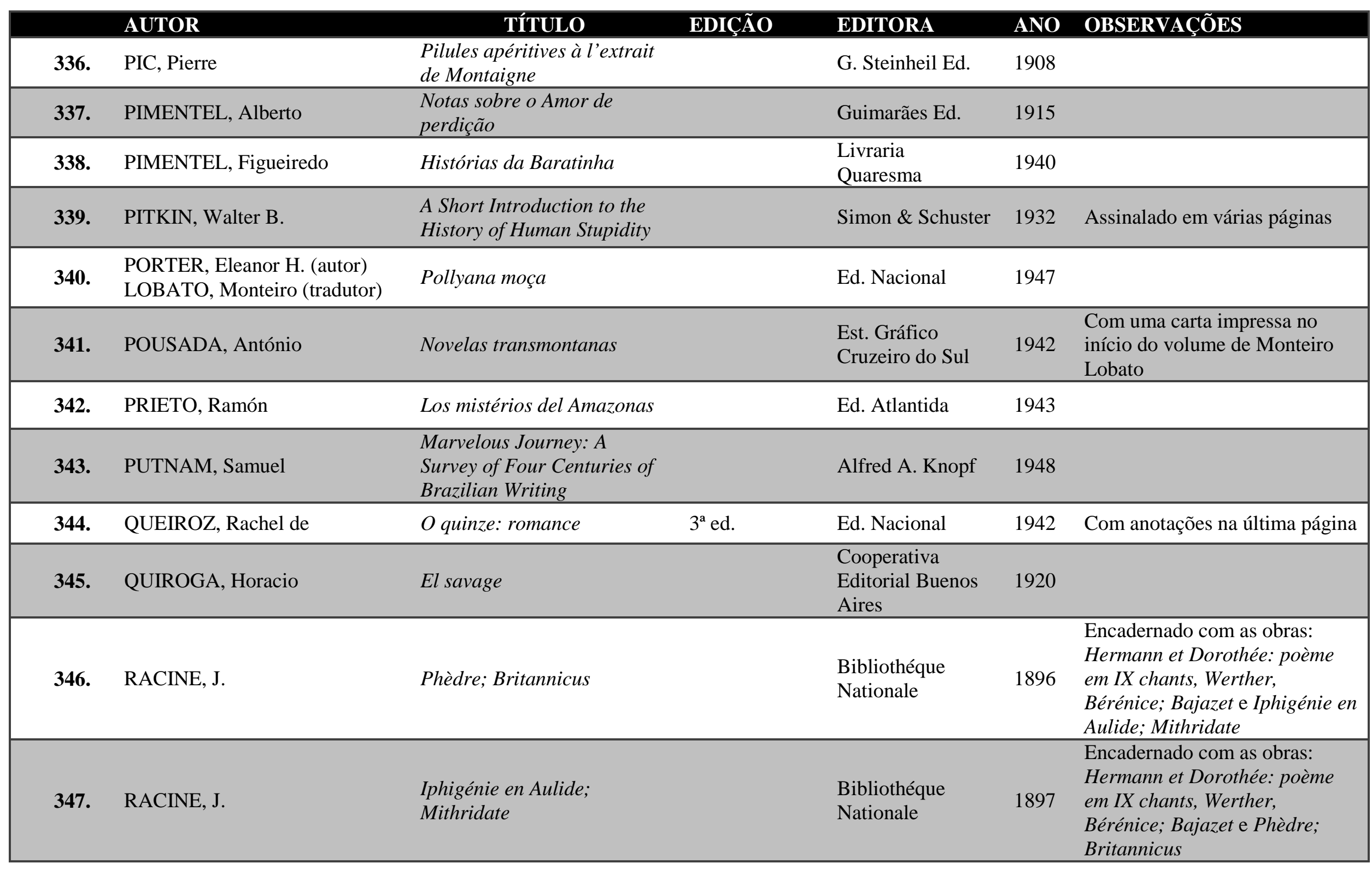




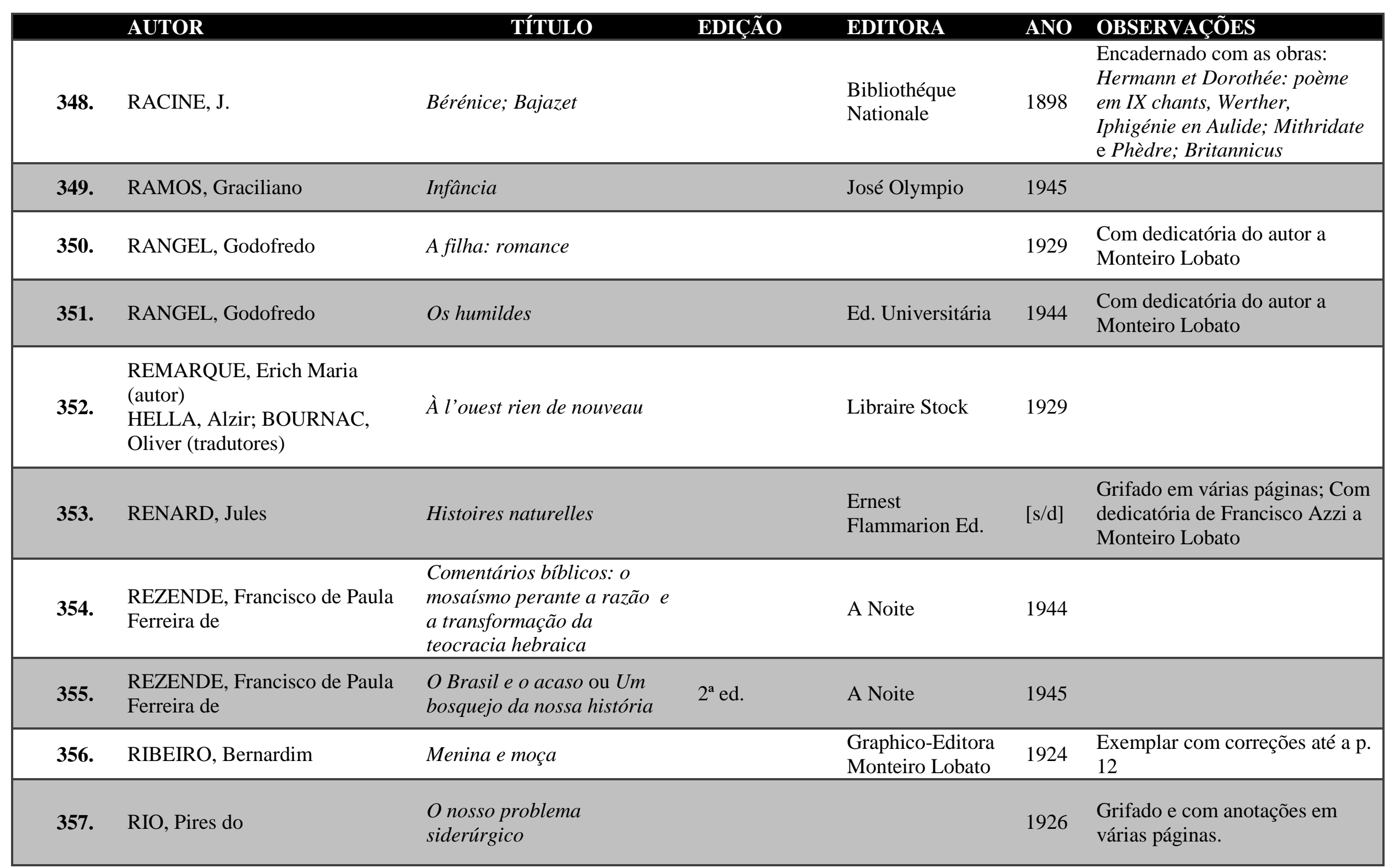




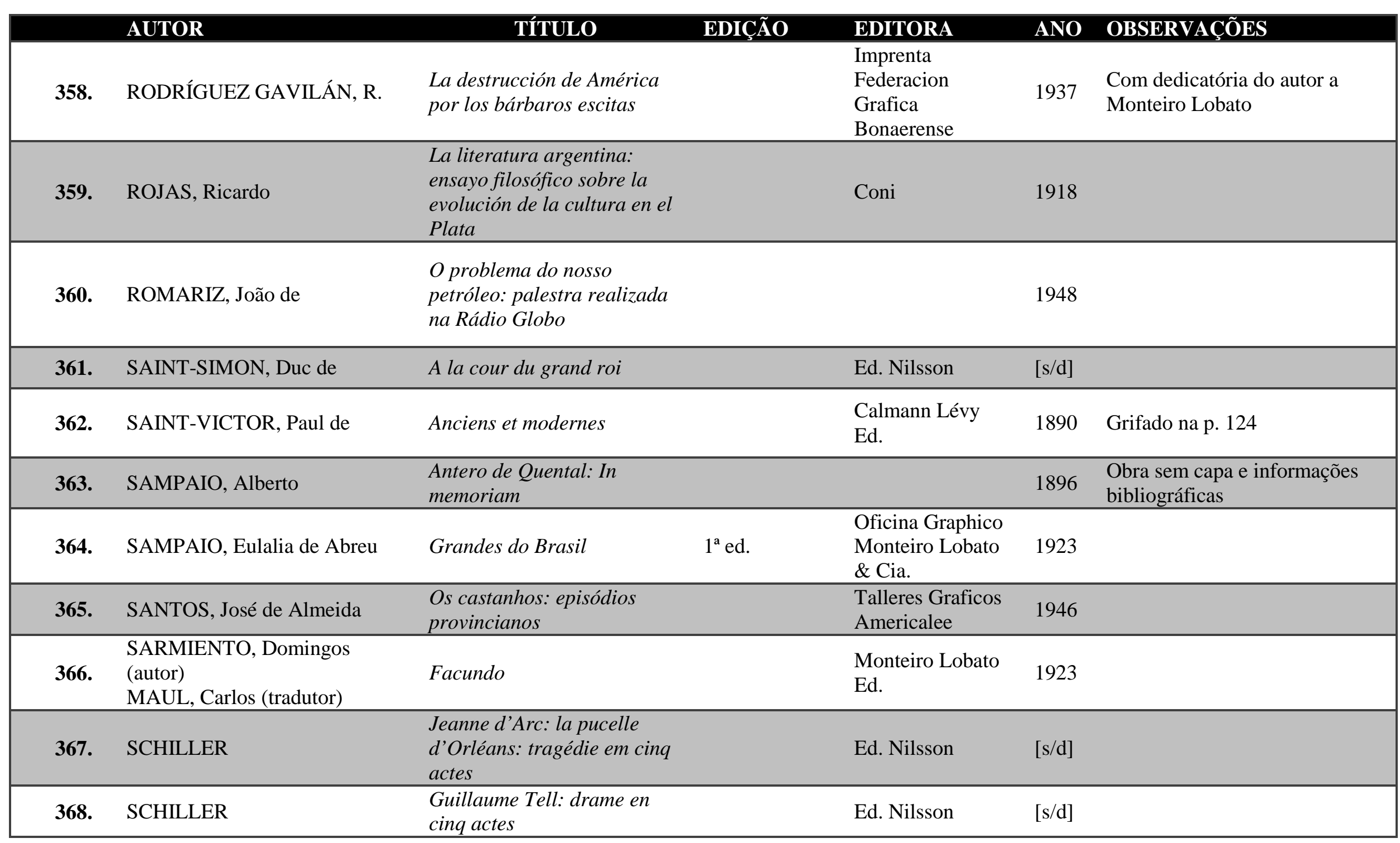




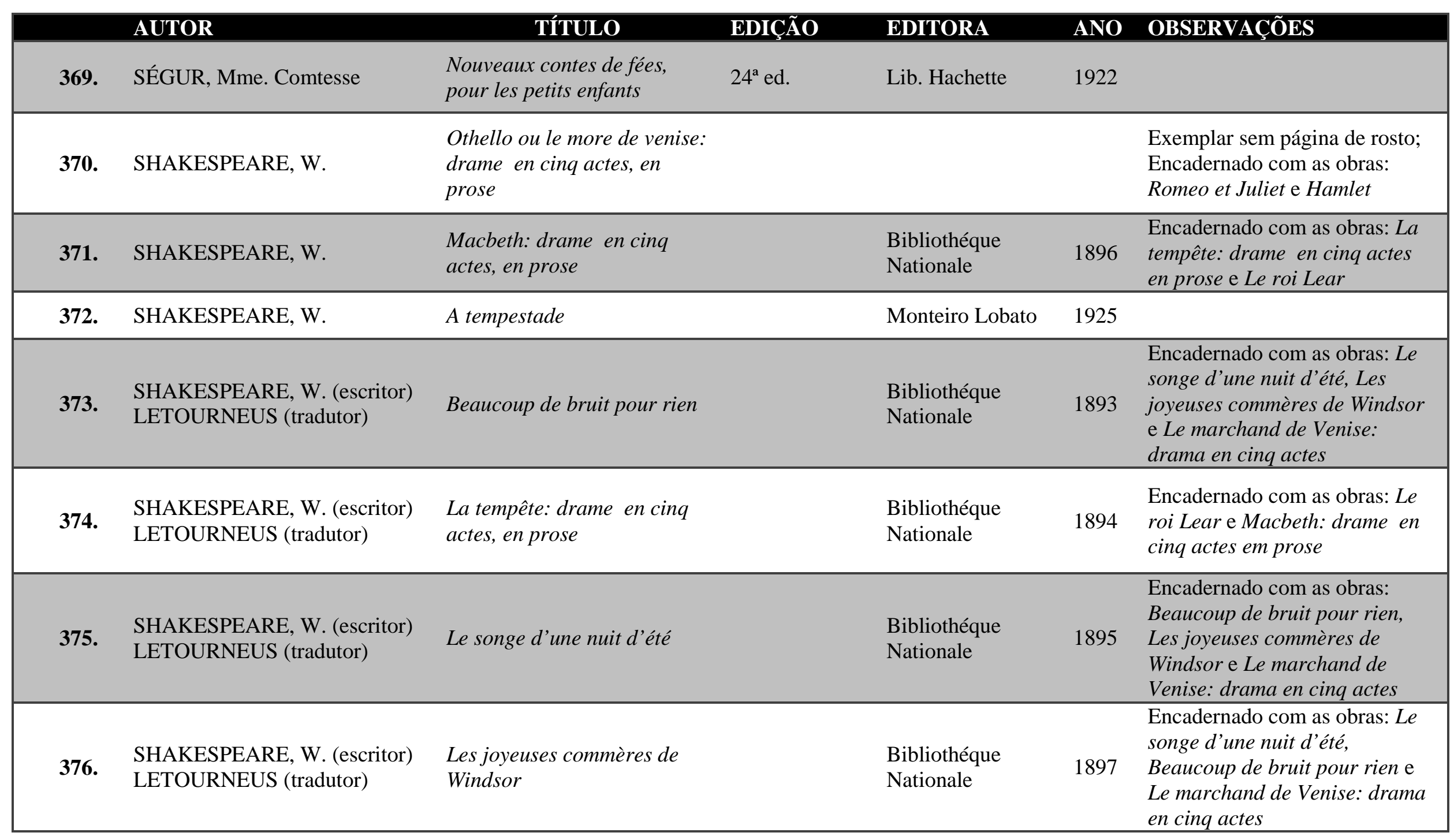




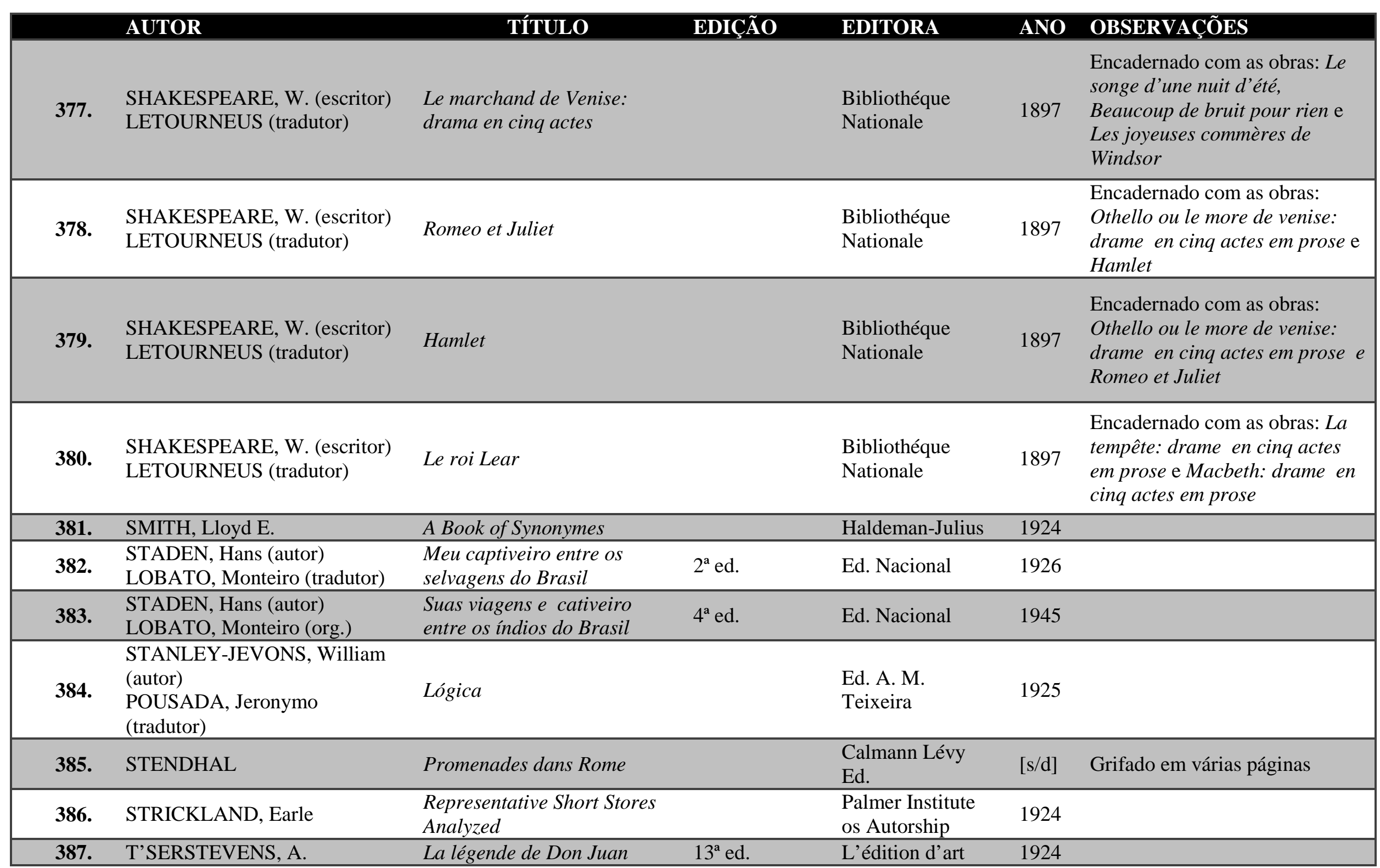




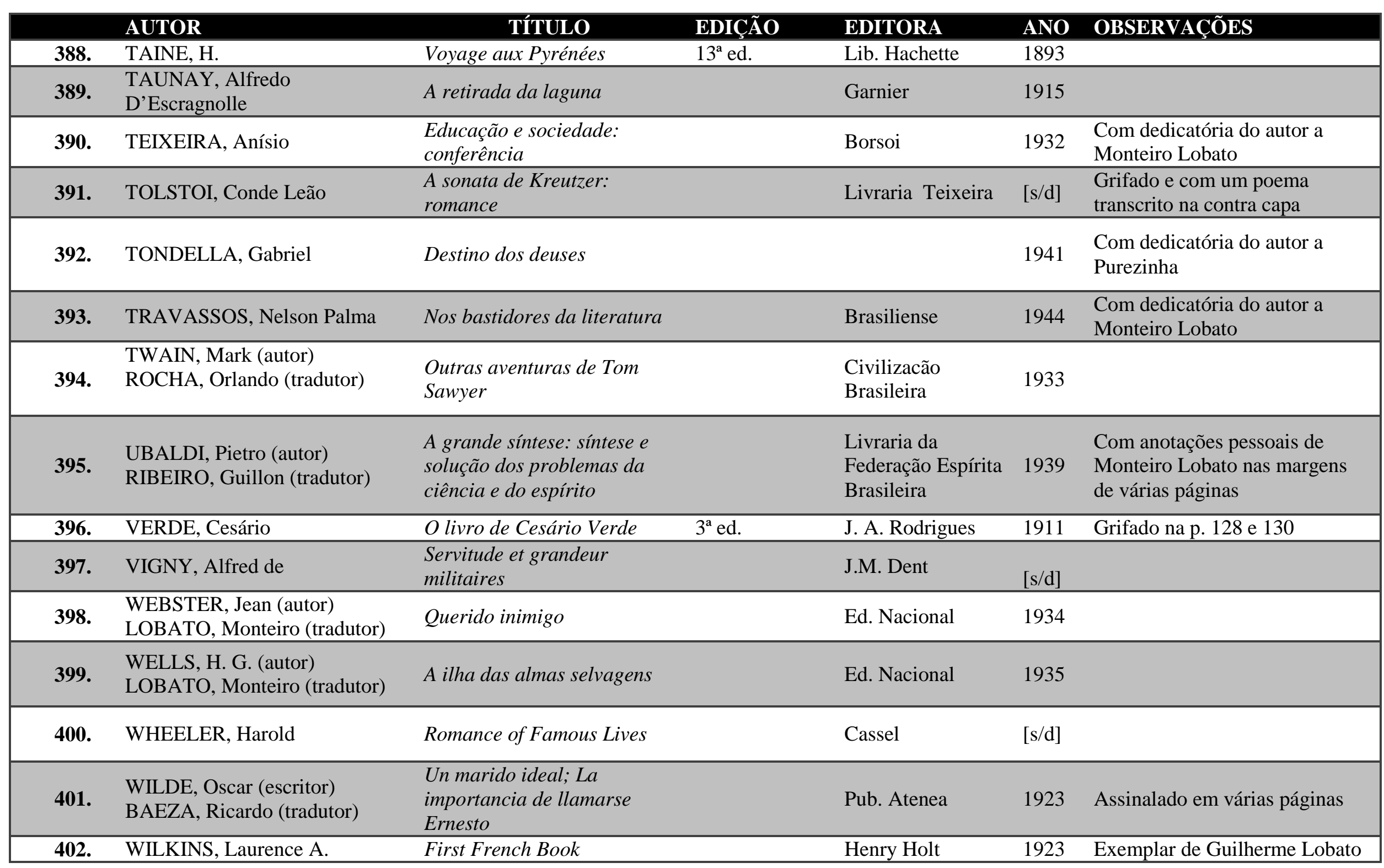




\begin{tabular}{|c|c|c|c|c|}
\hline AUTOR & TÍTULO & EDITORA & ANO & OBSERVAÇÕES \\
\hline 403. & $\begin{array}{l}\text { Les Mille Nouvelles } \\
\text { Nouvelles: revue mensuelle } \\
\text { pour tous }\end{array}$ & Jean Gillequin & {$[\mathrm{s} / \mathrm{d}]$} & \\
\hline 405. & The Borgias; The Cenci & P. J. Collier & 1910 & \\
\hline 407. & Revista do Brasil & & $\begin{array}{l}1922- \\
1925\end{array}$ & $\begin{array}{l}83,85,86,88,89,90,91,92,93 \\
94,95,96,98,99,100,101,102 \\
103,104,105,106,107,109,113\end{array}$ \\
\hline 408. & Reino mineral & Cabaut Ed. & 1924 & \\
\hline 409. & Revue de l'Amerique Latine & & $\begin{array}{l}1924- \\
1929\end{array}$ & $\begin{array}{l}\text { Todos os volumes citam } \\
\text { Monteiro Lobato }\end{array}$ \\
\hline 412. & La Revue Nouvelle & & 1927 & ano $3, n^{\circ} 17$ \\
\hline 413. & $\begin{array}{l}\text { Revista da Academia } \\
\text { Paulista de Letras }\end{array}$ & & $\begin{array}{l}1937- \\
1946\end{array}$ & $\begin{array}{l}\mathrm{n}^{\mathrm{o}}: 1,2,3,6,7,8,11,16,18,19 \\
25,26,28,30,31,33\end{array}$ \\
\hline 414. & $\begin{array}{l}\text { Revista da Academia } \\
\text { Paulista de Letras }\end{array}$ & & $\begin{array}{l}1937- \\
1946\end{array}$ & $\begin{array}{l}\mathrm{n}^{\mathrm{o}}: 9,15,32,36,39,42,43,46 \\
47,49,50,83\end{array}$ \\
\hline 415. & Vamos ler! & & 1939 & Ano $4, n^{\circ} 127$ \\
\hline 416. & The Interamerican Quaterly & & 1940 & v. 2, n. $^{\circ} 4$ \\
\hline 417. & Letras Brasileiras & A Noite & 1943 & ano $1, n^{\circ} 5$ \\
\hline
\end{tabular}




\begin{tabular}{|c|c|c|c|c|}
\hline AUTOR & EDIÇÃ̃O & EDITORA & ANO & OBSERVAÇÕES \\
\hline 418. & Atlantida & & 1946 & $\begin{array}{l}\text { Ano } 29, n^{\circ} 957 \text {. Com } \\
\text { dedicatória a Monteiro Lobato }\end{array}$ \\
\hline 419. & $\begin{array}{l}\text { Pequeña antologia de } \\
\text { cuentos brasileños }\end{array}$ & Editorial Nova & 1946 & \\
\hline 420. & Terra e liberdade & $\begin{array}{l}\text { Revista dos } \\
\text { Tribunais }\end{array}$ & 1947 & \\
\hline 421. & Fan Magazine & & 1948 & $\begin{array}{l}\text { ano } 1, \mathrm{n}^{\circ} 7 \text {; Contendo libreto de } \\
\text { "Narizinho" em opereta }\end{array}$ \\
\hline
\end{tabular}


Complemento H - Livros que integram o Fundo Monteiro Lobato, da Unicamp

\begin{tabular}{|c|c|c|c|c|c|c|c|}
\hline & AUTOR & TÍTULO & IDIOMA & EDIÇÃO & EDITORA & ANO & OBSERVAÇÕES \\
\hline 1. & ALENCAR, José de & As minas de prata & português & & Livraria Garnier & 1923 & \\
\hline 2. & $\begin{array}{l}\text { Aristophanes } \\
\text { BROTIER, André-Charles } \\
\text { (tradutor) }\end{array}$ & Théatre d'Aristophane & francês & & & 1896 & \\
\hline 3. & ASQUITH, Lady Cynthia & $\begin{array}{l}\text { The Treasure Ship: a } \\
\text { book of prose and verse }\end{array}$ & inglês & & & 1926 & \\
\hline 4. & ASSIS, Machado de & A mão e a luva & português & & Livraria Garnier & 1907 & \\
\hline 5. & $\begin{array}{l}\text { BARRINGTON, E. - (Autor) } \\
\text { LOBATO, Monteiro - } \\
\text { (Tradutor) }\end{array}$ & Cleópatra & português & & $\begin{array}{l}\text { Companhia } \\
\text { Editora } \\
\text { Nacional }\end{array}$ & 1935 & \\
\hline 6. & BILAC, Olavo & Poesias & português & $4^{\mathrm{a}}$ ed. & Francisco Alves & 1906 & $\begin{array}{l}\text { Dedicatória: "Ao Bello espirito } \\
\text { de Adalgiso Pereira, } \\
\text { affectuosamente, Olavo Bilac. } \\
\text { S. Paulo, 1915." No verso da } \\
\text { folha de rosto há uma poesia } \\
\text { ms., "Assombrações", de } \\
\text { Olavo Bilac. }\end{array}$ \\
\hline 7. & $\begin{array}{l}\text { CARLOWITZ, Baronne A. de - } \\
\text { (Tradutor) }\end{array}$ & $\begin{array}{l}\text { Mémoires de Goethe: } \\
\text { voyages, campagne de } \\
\text { France et annales }\end{array}$ & francês & & G. Charpentier & 1885 & \\
\hline 8. & $\begin{array}{l}\text { CELLINI, Benvenuto - (Autor) } \\
\text { MOREIRA, J.L. - (Tradutor) }\end{array}$ & $\begin{array}{l}\text { Vida de Benvenuto } \\
\text { Cellini: escrita por ele } \\
\text { mesmo }\end{array}$ & português & & & 1939 & \\
\hline 9. & COVICI, Pascal & Steinbeck & inglês & & $\begin{array}{l}\text { Viking Press } \\
\text { (The Viking } \\
\text { Portable } \\
\text { Library) } \\
\end{array}$ & 1943 & \\
\hline
\end{tabular}




\begin{tabular}{|c|c|c|c|c|c|c|c|}
\hline & AUTOR & TÍTULO & IDIOMA & EDIÇÃO & EDITORA & ANO & OBSERVAÇÕES \\
\hline 10. & DAVIS, F.A & $\begin{array}{l}\text { Studies in the } \\
\text { Psychology of Sex, v.6: } \\
\text { Sex in Relation to } \\
\text { Society }\end{array}$ & inglês & & & 1931 & $\begin{array}{l}\text { Contém recorte c/ imagem do } \\
\text { autor }\end{array}$ \\
\hline 11. & DUPRÉ, Leandro & Éramos seis & português & $4^{\mathrm{a}}$ ed. & $\begin{array}{l}\text { Editora } \\
\text { Brasiliense }\end{array}$ & 1944 & \\
\hline 12. & $\begin{array}{l}\text { DURANT, Will - (Autor) } \\
\text { LOBATO, Monteiro - } \\
\text { (Tradutor) }\end{array}$ & $\begin{array}{l}\text { Historia da civilização: } \\
\text { nossa herança oriental }\end{array}$ & português & & $\begin{array}{l}\text { Companhia } \\
\text { Editora } \\
\text { Nacional }\end{array}$ & 1942 & \\
\hline 13. & $\begin{array}{l}\text { DURANT, Will - (Autor) } \\
\text { LOBATO, Gulnara de Morais }\end{array}$ & $\begin{array}{l}\text { Historia da civilização: } \\
\text { nossa herança clássica: } \\
\text { a vida na Grécia }\end{array}$ & português & & $\begin{array}{l}\text { Companhia } \\
\text { Editora } \\
\text { Nacional }\end{array}$ & 1943 & \\
\hline 14. & $\begin{array}{l}\text { DURANT, Will - (Autor) } \\
\text { LOBATO, Monteiro - } \\
\text { (Tradutor) }\end{array}$ & $\begin{array}{l}\text { Historia da civilização: } \\
\text { Cesar e Cristo }\end{array}$ & português & & & 1946 & \\
\hline 15. & FERRAZ, Mário de Sampaio & Campos do Jordão & português & $3^{\mathrm{a}}$ ed. & $\begin{array}{l}\text { Directoria de } \\
\text { Publicidade } \\
\text { Agricola da } \\
\text { Secretaria da } \\
\text { Agricultura, } \\
\text { Industria e } \\
\text { Commercio }\end{array}$ & 1940 & \\
\hline 16. & FERRAZ, Mário de Sampaio & Campos do Jordão & português & $4^{\mathrm{a}}$ ed. & $\begin{array}{l}\text { Directoria de } \\
\text { Publicidade } \\
\text { Agricola da } \\
\text { Secretaria da } \\
\text { Agricultura, } \\
\text { Industria e } \\
\text { Commercio }\end{array}$ & 1941 & \\
\hline 17. & FILHO, Cantinho & Os bacharéis de 1904 & português & & $\begin{array}{l}\text { Faculdade de } \\
\text { Direito de São } \\
\text { Paulo }\end{array}$ & 1934 & Com anotações \\
\hline
\end{tabular}




\section{AUTOR}

\begin{tabular}{|rl}
\hline \multicolumn{2}{|l}{ AUTOR } \\
18. & FRANCE, Anatole \\
\hline $\mathbf{1 9}$. & FRANCE, Anatole - (Autor) \\
\hline $\mathbf{2 0 .}$ & $\begin{array}{l}\text { GAMOW, George - (Autor) } \\
\text { LOBATO, Monteiro - } \\
\text { (Tradutor) }\end{array}$ \\
\hline
\end{tabular}

TÍTULO

Les contes de Jacques Tournebroche

IDIOMA

francês
La révolte des anges Nascimento e morte do sol: evolução estelar energia sub-atômica

Atlas de

21. Grosselin-Delamarche géographie: physique, francês

francês politique et historique

português

Globo

Libr.

Géographie de 1894

Émile Bertaux

Longmans, Green and Co.

Charles

Scribner's Sons

1940

Companhia

Editora

Nacional

Por quem os sinos

dobram

português $\quad 3^{\mathrm{a}} \mathrm{ed}$

\begin{tabular}{|c|c|c|c|c|c|c|}
\hline 25. & $\begin{array}{l}\text { Instituto Medicamenta Fontoura } \\
\& \text { Serpe - (Entidade Produtora) }\end{array}$ & Almanaque do Biotônico & português & & $\begin{array}{l}9 \text { vol. de } \\
1932- \\
1940\end{array}$ & $\begin{array}{l}\text { Contém apenas as capas do } \\
\text { Almanaque de 1932. São nove } \\
\text { volumes encadernados } \\
\text { conjuntamente. }\end{array}$ \\
\hline 26. & $\begin{array}{l}\text { Instituto Medicamenta Fontoura } \\
\& \text { Serpe - (Entidade Produtora) }\end{array}$ & Almanaque do Biotônico & português & & 1944 & \\
\hline 27. & $\begin{array}{l}\text { KIPLING, Rudyard - (Autor) } \\
\text { LOBATO, Monteiro - } \\
\text { (Tradutor) }\end{array}$ & Mowgli: o menino lobo & português & $\begin{array}{l}\text { Companhia } \\
\text { Editora } \\
\text { Nacional }\end{array}$ & 1933 & \\
\hline 28. & $\begin{array}{l}\text { KIPLING, Rudyard - (Autor) } \\
\text { LOBATO, Monteiro - } \\
\text { (Tradutor) }\end{array}$ & O livro do Jângal & português & $\begin{array}{l}\text { Companhia } \\
\text { Editora } \\
\text { Nacional }\end{array}$ & 1941 & \\
\hline
\end{tabular}




\begin{tabular}{|c|c|c|c|c|c|c|c|}
\hline & AUTOR & TÍTULO & IDIOMA & EDIÇÃ̃O & EDITORA & ANO & OBSERVAÇÕES \\
\hline 29. & $\begin{array}{l}\text { KIPLING, Rudyard - (Autor) } \\
\text { LOBATO, Monteiro - } \\
\text { (Tradutor) }\end{array}$ & Kim & português & & $\begin{array}{l}\text { Companhia } \\
\text { Editora } \\
\text { Nacional }\end{array}$ & 1945 & \\
\hline 30. & LESSA, Orígenes & $\begin{array}{l}\text { Omelete em } \\
\text { Bombaim: contos }\end{array}$ & português & & O Cruzeiro & 1946 & \\
\hline 31. & LOBATO, Monteiro & Jéca Tatuzinho & português & & & [1925?] & \\
\hline 32. & LOBATO, Monteiro & Jéca Tatuzinho & japonês? & & & [1925] & \\
\hline 33. & LOBATO, Monteiro & $\begin{array}{l}\text { O garimpeiro do Rio } \\
\text { das Garças }\end{array}$ & português & & $\begin{array}{l}\text { Companhia } \\
\text { Editora } \\
\text { Nacional }\end{array}$ & 1937 & \\
\hline 34. & LOBATO, Monteiro & Zé Brasil & português & & & 1947 & \\
\hline 35. & $\begin{array}{l}\text { LOBATO, Monteiro - (Autor) } \\
\text { PRIETO, Juan Ramón - } \\
\text { (Tradutor) }\end{array}$ & $\begin{array}{l}\text { Urupés: cuentos } \\
\text { brasileiros }\end{array}$ & espanhol & & & 1947 & \\
\hline 36. & $\begin{array}{l}\text { LOBATO, Monteiro - (Autor) } \\
\text { STUART, Aubrey - (Tradutor) }\end{array}$ & $\begin{array}{l}\text { How Henry Ford is } \\
\text { regarded in Brazil }\end{array}$ & inglês & & "O Jornal" & 1926 & \\
\hline 37. & $\begin{array}{l}\text { LOBATO, Monteiro - } \\
\text { (Organizador) }\end{array}$ & $\begin{array}{l}\text { Hans Staden: suas } \\
\text { viagens e cativeiro entre } \\
\text { os índios do Brasil }\end{array}$ & português & $4^{\mathrm{a}}$ ed. & $\begin{array}{l}\text { Companhia } \\
\text { Editora } \\
\text { Nacional }\end{array}$ & 1945 & \\
\hline 38. & $\begin{array}{l}\text { LOBATO, Monteiro - } \\
\text { (Tradutor) }\end{array}$ & $\begin{array}{l}\text { Aventuras do Barão de } \\
\text { Munchausen: narradas } \\
\text { por ele mesmo }\end{array}$ & português & & & [1939?] & $\begin{array}{l}\text { Texto em quadrinhos. Álbum } \\
\text { N.3, } 8 \text { aventuras em } 48 \\
\text { quadros. Data: [1939?]: } \\
\text { extraído do anúncio do livro } \\
\text { Obras de Casimiro de Abreu: } \\
\text { Edição comemorativa do } \\
\text { centenário do poeta. }\end{array}$ \\
\hline
\end{tabular}




\begin{tabular}{|c|c|c|c|c|c|c|c|}
\hline & AUTOR & TÍTULO & IDIOMA & EDIÇÃO & EDITORA & ANO & OBSERVAÇÕES \\
\hline 39. & $\begin{array}{l}\text { LONDON, Jack - (Autor) } \\
\text { LOBATO, Monteiro - } \\
\text { (Tradutor) }\end{array}$ & O lobo do mar & português & & $\begin{array}{l}\text { Companhia } \\
\text { Editora } \\
\text { Nacional }\end{array}$ & 1934 & \\
\hline 41. & $\begin{array}{l}\text { MACY, John - (Autor) } \\
\text { LOBATO, Monteiro - } \\
\text { (Tradutor) }\end{array}$ & $\begin{array}{l}\text { História da literatura } \\
\text { mundial }\end{array}$ & português & $2^{\mathrm{a}}$ ed. & $\begin{array}{l}\text { Companhia } \\
\text { Editora } \\
\text { Nacional }\end{array}$ & 1941 & \\
\hline 43. & MAUGHAM, W. Somerset & Servidão humana & português & & Edições Globo & 1939 & \\
\hline 46. & MORAES, Heitor de & Ao luar da musica & português & & $\begin{array}{l}\text { Ed. da } \\
\text { Commissao } \\
\text { Glorificadora de } \\
\text { Martins Fontes }\end{array}$ & 1938 & Contém dedicatória \\
\hline 47. & MOREYRA, Alvaro & $\begin{array}{l}\text { Hoje tem espetáculo!: } \\
\text { bonecos de Alvarus }\end{array}$ & português & & Zelio Valverde & 1941 & $\begin{array}{l}\text { Dedicatória: "A Monteiro } \\
\text { Lobato a quem tanto admiro. } \\
\text { Avarus. Rio. Natal de } 942 . "\end{array}$ \\
\hline 48. & Não identificado & $\begin{array}{l}\text { Investiment Features of } \\
\text { Cooperative Apartment } \\
\text { Ownership at Jackson } \\
\text { Heights }\end{array}$ & inglês & & & 1925 & \\
\hline
\end{tabular}




\begin{tabular}{|c|c|c|c|c|c|c|c|}
\hline & AUTOR & TÍTULO & IDIOMA & EDIÇÃ̃O & EDITORA & ANO & OBSERVAÇÕES \\
\hline 49. & Não identificado & Terra e liberdade & português & & $\begin{array}{l}\text { Revista dos } \\
\text { Tribunais }\end{array}$ & 1947 & \\
\hline 50. & Não identificado & Vamos ter & português & & & $\begin{array}{l}25 \text { jan. } \\
1940\end{array}$ & \\
\hline 51. & PARSENS, Geoffrey & The Stream of History & inglês & & & 1929 & \\
\hline 52. & POLO, Marco & $\begin{array}{l}\text { Travels of Marco Polo: } \\
\text { the venetian }\end{array}$ & inglês & $10^{\mathrm{a}} \mathrm{ed}$ & $\begin{array}{l}\text { Horace } \\
\text { Liveright }\end{array}$ & 1932 & \\
\hline 53. & QUEIRÓS, Eça & A relíquia & português & $8^{a}$ ed. & Lélo e Irmão & 1924 & \\
\hline 54. & QUIROGA, Horácio & Anaconda & espanhol & & $\begin{array}{l}\text { Agencia General } \\
\text { de Libreria y } \\
\text { Publicacion }\end{array}$ & 1921 & Contém dedicatória \\
\hline 55. & RAMOS, Graciliano & São Bernardo & português & $2^{\mathrm{a}}$ ed. & $\begin{array}{l}\text { Livraria José } \\
\text { Olympio Editora }\end{array}$ & 1938 & $\begin{array}{l}\text { Dedicatória: "Para o grande } \\
\text { Monteiro Lobato. Graciliano } \\
\text { Ramos. Rio. 1938" }\end{array}$ \\
\hline 56. & $\begin{array}{l}\text { RICHEPAN, M. Juan - (Diretor) } \\
\text { Montaner y Simon - (Editor) }\end{array}$ & $\begin{array}{l}\text { Nueva mitologia } \\
\text { Ilustrada: documental, } \\
\text { artística, literária }\end{array}$ & espanhol & & $\begin{array}{l}\text { Montaner y } \\
\text { Simon }\end{array}$ & 1927 & \\
\hline 57. & $\begin{array}{l}\text { ROBINSON, James Harvey - } \\
\text { (Autor) } \\
\text { LOBATO, Monteiro - } \\
\text { (Tradutor) }\end{array}$ & $\begin{array}{l}\text { A formação da } \\
\text { mentalidade }\end{array}$ & português & & $\begin{array}{l}\text { Companhia } \\
\text { Editora } \\
\text { Nacional }\end{array}$ & 1940 & \\
\hline 58. & $\begin{array}{l}\text { ROBINSON, James Harvey - } \\
\text { (Autor) } \\
\text { LOBATO, Monteiro - } \\
\text { (Tradutor) }\end{array}$ & $\begin{array}{l}\text { A formação da } \\
\text { mentalidade }\end{array}$ & português & & $\begin{array}{l}\text { Companhia } \\
\text { Editora } \\
\text { Nacional }\end{array}$ & 1945 & \\
\hline 59. & $\begin{array}{l}\text { SAAVEDRA, Miguel de } \\
\text { Cervantes - (Autor) } \\
\text { Visconde de Castilho - } \\
\text { (Tradutor) } \\
\text { Visconde de Azevedo - } \\
\text { (Tradutor) }\end{array}$ & $\begin{array}{l}\text { Engenhoso fidalgo Don } \\
\text { Quixote de La Mancha }\end{array}$ & português & & $\begin{array}{l}\text { Imprensa da } \\
\text { Companhia } \\
\text { Litterária }\end{array}$ & 1876 & Contém dedicatória \\
\hline
\end{tabular}




\begin{tabular}{|c|c|c|c|c|c|c|}
\hline & AUTOR & TÍTULO & IDIOMA EDIÇÃO & EDITORA & ANO & OBSERVAÇÕES \\
\hline 60. & SALIAT, Pierre (tradutor) & Histoires d'Hérodote & francês & Henri Plon & 1864 & Com anotações \\
\hline 61. & $\begin{array}{l}\text { SCOTT, Walter - (Autor) } \\
\text { DEFAUCONPRET, M. - } \\
\text { (Tradutor) }\end{array}$ & $\begin{array}{l}\text { Oeuvres de Walter } \\
\text { Scott: la jolie fille de } \\
\text { Perth (tome 22) }\end{array}$ & francês & Combet; Garnier & {$[\mathrm{s} / \mathrm{d}]$} & \\
\hline 62. & SILVESTRE, Armand & Le nu au salon de 1897 & francês & $\begin{array}{l}\text { Librairie E. } \\
\text { Bernard et Cie }\end{array}$ & 1897 & \\
\hline 63. & $\begin{array}{l}\text { SIMONS, Théodore - (Autor) } \\
\text { LEMERCHER, Marcel - } \\
\text { (Tradutor) }\end{array}$ & L'Espagne & francês & Léon Vanier & 1884 & \\
\hline 64. & TAYLOR, Deems & Walt Disney's Fantasia & inglês & & 1940 & \\
\hline 65. & $\begin{array}{l}\text { WELLS, H.G. - (Autor) } \\
\text { LOBATO, Monteiro - } \\
\text { (Tradutor) }\end{array}$ & História do futuro & português & $\begin{array}{l}\text { Companhia } \\
\text { Editora } \\
\text { Nacional }\end{array}$ & 1940 & \\
\hline 66. & $\begin{array}{l}\text { WELLS, H.G. - (Autor) } \\
\text { LOBATO, Monteiro - } \\
\text { (Tradutor) }\end{array}$ & $\begin{array}{l}\text { O destino da espécie } \\
\text { humana }\end{array}$ & português & $\begin{array}{l}\text { Companhia } \\
\text { Editora } \\
\text { Nacional }\end{array}$ & 1941 & \\
\hline 67. & Weygand, Général & $\begin{array}{l}\text { Histoire de l'Année } \\
\text { Française }\end{array}$ & francês & E. Flammarion & 1938 & \\
\hline 68. & WILDER, Thornton & $\begin{array}{l}\text { The Bridge of San Luis } \\
\text { Rey }\end{array}$ & inglês & $\begin{array}{l}\text { Grosset \& } \\
\text { Dunlap }\end{array}$ & 1927 & $\begin{array}{l}\text { Contém recorte c/ imagem do } \\
\text { autor }\end{array}$ \\
\hline 69. & $\begin{array}{l}\text { WREN, P.C. - (Autor) } \\
\text { LOBATO, Monteiro - } \\
\text { (Tradutor) }\end{array}$ & Beau Geste & português & $\begin{array}{l}\text { Companhia } \\
\text { Editora } \\
\text { Nacional }\end{array}$ & 1935 & \\
\hline 70. & & $\begin{array}{l}\text { [Dedicatórias de Plínio } \\
\text { Salgado, Dilermando de } \\
\text { Assis, Martins Fontes, } \\
\text { Gumarães Rosa, José } \\
\text { Lins do Rego, José } \\
\text { Guilherme de Araújo } \\
\text { Jorge, Hugo Wast, Juan } \\
\text { Pablo Muñoz Sanz, } \\
\text { Antonio Batista Pereira, } \\
\text { enviadas a ML] - }\end{array}$ & $\begin{array}{l}\text { português } \\
\text { e } \\
\text { espanhol }\end{array}$ & & $\begin{array}{l}25 \text { ago } \\
1918 \text { - } \\
\text { jul. } \\
1947\end{array}$ & $\begin{array}{l}\text { Dedicatórias em folhas de } \\
\text { rosto dos livros Flor de } \\
\text { Durazno; Cuentos del Río de } \\
\text { La Plata; Vultos e Episódios } \\
\text { do Brasil; Glosario de Amiel; } \\
\text { Sagarana; Estrela da Terra; } \\
\text { Banquê. }\end{array}$ \\
\hline
\end{tabular}




\begin{tabular}{|c|c|c|c|c|c|}
\hline AUTOR & TÍTULO & IDIOMA EDIÇÃO & EDITORA & ANO & OBSERVAÇÕES \\
\hline 71. & The Little Times & inglês & $\begin{array}{l}\text { Lyman, Edward } \\
\text { A. }\end{array}$ & $\begin{array}{l}15 \text { dez. } \\
1928\end{array}$ & $\begin{array}{l}\text { Nota do noivado de Martha } \\
\text { Lobato e Jurandir Ubirajara } \\
\text { Campos }\end{array}$ \\
\hline 72. & Fantasia & português & $\begin{array}{l}\text { Walt Disney } \\
\text { Productions }\end{array}$ & 1940 & \\
\hline 73. & $\begin{array}{l}\text { Propaganda do livro } \\
\text { História do mundo para } \\
\text { as crianças de Monteiro } \\
\text { Lobato publicado pela } \\
\text { Companhia Editora } \\
\text { Nacional. A Noite } \\
\text { Ilustrada }\end{array}$ & português & & 1933 & \\
\hline 74. & $\begin{array}{l}\text { [Catálogos das Obras de } \\
\text { Monteiro Lobato] }\end{array}$ & $\begin{array}{l}\text { português } \\
\text { e } \\
\text { espanhol }\end{array}$ & & [1947] & $\begin{array}{l}\text { Contendo catálogo com } \\
\text { sinopses dos livros do titular: } \\
\text { Coleção Completa da Ed. } \\
\text { Brasiliense e Biblioteca } \\
\text { Infantil do Editoral } \\
\text { Amaricalee. }\end{array}$ \\
\hline
\end{tabular}

